\title{
De Overijsselse arbeidsmarkt naar opleiding en beroep : 2001-2006
}

Citation for published version (APA):

Borghans, L., Cörvers, F., Golsteyn, B. H. H., Hensen, M. M., \& Kriechel, B. (2003). De Overijsselse arbeidsmarkt naar opleiding en beroep : 2001-2006. Researchcentrum voor Onderwijs en Arbeidsmarkt, Faculteit der Economische Wetenschappen. ROA Reports No. 10 https://doi.org/10.26481/umarep.2003010

Document status and date:

Published: 01/01/2003

DOI:

10.26481/umarep.2003010

Document Version:

Publisher's PDF, also known as Version of record

\section{Please check the document version of this publication:}

- A submitted manuscript is the version of the article upon submission and before peer-review. There can be important differences between the submitted version and the official published version of record.

People interested in the research are advised to contact the author for the final version of the publication, or visit the DOI to the publisher's website.

- The final author version and the galley proof are versions of the publication after peer review.

- The final published version features the final layout of the paper including the volume, issue and page numbers.

Link to publication

\footnotetext{
General rights rights.

- You may freely distribute the URL identifying the publication in the public portal. please follow below link for the End User Agreement:

www.umlib.nl/taverne-license

Take down policy

If you believe that this document breaches copyright please contact us at:

repository@maastrichtuniversity.nl

providing details and we will investigate your claim.
}

Copyright and moral rights for the publications made accessible in the public portal are retained by the authors and/or other copyright owners and it is a condition of accessing publications that users recognise and abide by the legal requirements associated with these

- Users may download and print one copy of any publication from the public portal for the purpose of private study or research.

- You may not further distribute the material or use it for any profit-making activity or commercial gain

If the publication is distributed under the terms of Article $25 \mathrm{fa}$ of the Dutch Copyright Act, indicated by the "Taverne" license above, 
De Overijsselse arbeidsmarkt naar opleiding en beroep

2001-2006

ROA-R-2003/10
L. Borghans
F. Cörvers
B. Golsteyn
M. Hensen
B. Kriechel

\section{Researchcentrum voor Onderwijs en Arbeidsmarkt \\ Faculteit der Economische Wetenschappen en Bedrijfskunde Universiteit Maastricht}

Maastricht, september 2003 
Niets uit deze uitgave mag worden verveelvoudigd en/of openbaar gemaakt door middel van druk, fotokopie, microfilm, of op welke wijze ook, zonder voorafgaande schriftelijke toestemming van de directeur van het Researchcentrum voor Onderwijs en Arbeidsmarkt. In geval van overname van het datamateriaal moet telkens als bron worden vermeld: "Researchcentrum voor Onderwijs en Arbeidsmarkt" of "ROA". Van publicaties waarin gebruik wordt gemaakt van gegevens uit dit rapport ontvangen wij gaarne een exemplaar.

Hoewel de grootst mogelijke zorg is besteed aan de inhoud van dit rapport, kan het ROA in generlei opzicht verantwoordelijkheid op zich nemen voor eventuele onvolledigheden of onjuistheden.

ISBN 90-5321-373-2

Sec03.096.doc 


\section{Inhoud}

Bladzijde

Voorwoord

Ten geleide $\quad$ iii

Resumé vii

1 De Overijsselse arbeidsmarkt in vogelvlucht $\quad 1$

1.1 Inleiding 2

1.2 Groeitrends in Overijssel en Nederland 2

1.3 Kenmerken en ontwikkeling van de werkzame beroepsbevolking in
Overijssel

1.4 Actuele arbeidsmarktdiscrepanties in Overijssel 8

1.5 De verwachte arbeidsmarktontwikkelingen in Overijssel op
hoofdlijnen

1.6 De verwachte arbeidsmarktsituatie naar beroep en opleiding op de korte en middellange termijn 13

2 De instroom van schoolverlaters op de Overijsselse arbeidsmarkt $\quad 17$

$\begin{array}{ll}2.1 \text { Inleiding } & 18\end{array}$

2.2 Het aantal gediplomeerden in Overijssel 18

2.3 Het aantal leerlingen in Overijssel 20

$\begin{array}{ll}2.4 & \text { Aanbod van schoolverlaters } \\ \end{array}$

3 De vraag naar arbeidskrachten op de Overijsselse arbeidsmarkt 29

$\begin{array}{ll}3.1 \text { Inleiding } & 29\end{array}$

$\begin{array}{ll}3.2 \text { Uitbreidingsvraag } & 30\end{array}$

$\begin{array}{lll}3.3 & \text { Vervangingsvraag } & 38\end{array}$

$\begin{array}{ll}3.4 & \text { Baanopeningen }\end{array}$

4 Knelpunten en perspectieven op de Overijsselse arbeidsmarkt 53

$\begin{array}{ll}4.1 & \text { Inleiding } \\ 4.2 & 54\end{array}$

4.2 De arbeidsmarktperspectieven voor schoolverlaters 55

4.3 Knelpunten in de personeelsvoorziening voor werkgevers 60

4.4 Pendel als aanpassingsproces op de arbeidsmarkt 64

4.5 Pendelstromen tussen Overijssel en Duitsland 68

5 Overijssel in geografisch perspectief $\quad 71$

$\begin{array}{ll}5.1 \text { Inleiding } & 72\end{array}$

$\begin{array}{ll}5.2 \text { De positie van Overijssel } & 73\end{array}$

$\begin{array}{ll}5.3 \text { Het clusteren van werkgelegenheid } & 76\end{array}$

$\begin{array}{lll}5.4 & \text { Effecten van beleid } & 78\end{array}$

5.5 Appendix hoofdstuk 5: gebruikte indicatoren 90 
6 Het onbenutte arbeidspotentieel in Overijssel 93

$\begin{array}{ll}6.1 \text { Inleiding } & 93\end{array}$

6.2 Achtergrondkenmerken van het onbenutte arbeidspotentieel in Overijssel 95

6.3 Inzetbaarheid van het onbenutte arbeidspotentieel 99

6.4 Oorzaken en gevolgen van werkloosheid en non-participatie 102

$\begin{array}{ll}\text { Verklarende woordenlijst } & 107\end{array}$ 


\section{Voorwoord}

Voor u ligt de publicatie "De Overijsselse arbeidsmarkt 2001-2006", uitgevoerd door het Researchcentrum voor Onderwijs en Arbeidsmarkt (ROA) van de Universiteit Maastricht. Het is het resultaat van het project Regionaal ArbeidsmarkT Informatiesysteem Overijssel (RATIO), dat in gang is gezet om meer zicht te krijgen in de huidige en toekomstige situatie op de Overijsselse arbeidsmarkt.

Tot nu toe zijn vraag en aanbod in kwantitatief en kwalitatief opzicht niet goed op elkaar afgestemd geweest. De gehouden studie geeft inzicht in toekomstige vraagen aanbodverhoudingen naar opleiding en beroep, zodat er nu ook aanknopingspunten liggen om een betere aansluiting te realiseren tussen onderwijs en arbeidsmarkt. Omdat nu meer duidelijkheid bestaat over de toekomstige vragen vanuit het bedrijfsleven kan aan de arbeidsreserve ook beter richting worden gegeven in het belang van het goed functioneren van de arbeidsmarkt in de Overijsselse regio. De gegevens zijn dus een belangrijke bron van informatie voor de beleidsmakers in de regio. Ook voor de onderwijsinstellingen en de instanties die bij de beroeps- en studiekeuze een adviserende rol vervullen, biedt het rapport belangrijke informatie.

Daarnaast is de informatie uit dit rapport gebruikt als bronmateriaal voor de regionale verdiepingsonderzoeken die ten behoeve van de Regionale Platforms Arbeidsmarkt voor IJssel-Vecht en voor Twente zijn uitgevoerd. In samenhang met de regionale verdiepingsrapporten biedt dit rapport een goed inzicht in de regionale arbeidsmarkt van Overijssel.

Als verantwoordelijk bestuurder voor het provinciaal arbeidsmarktbeleid juich ik de publicatie van het voorliggend rapport van harte toe. Met het ter beschikking gekomen materiaal kan nu op een meer adequate en doelgerichte wijze op de gesignaleerde knelpunten op de Overijsselse arbeidsmarkt worden ingespeeld. Het huidige economisch tij en de als gevolg daarvan afnemende werkgelegenheid en stijgende werkloosheid vraagt een bijzondere inzet van de regionale arbeidsmarktpartijen, waaronder gemeenten, sociale partners, onderwijsinstellingen en de provincie. Het is zaak kansen en mogelijkheden te zien en te benutten en gezamenlijk te werken aan een goed functionerende arbeidsmarkt. Dit zowel in het belang van de participatie van de burgers aan de samenleving alsmede in het belang van een goede economische situatie binnen Overijssel.

Zo zal ten gevolge van de voortgaande vergrijzing en ontgroening op de middellange termijn van een ieder het maximale worden gevergd. Het is nu het moment te handelen. 
Graag wil ik in het belang van een goede werkgelegenheidsontwikkeling en grotere maatschappelijke betrokkenheid van de Overijsselse burgers alle partners vragen gezamenlijk bij te dragen aan de ontwikkeling en uitvoering van een regionaal arbeidsmarktbeleid. De nu beschikbare informatie staat ons ten dienste!

Carry Abbenhues

Gedeputeerde voor Economie en Innovatie van de Provincie Overijssel 


\section{Ten geleide}

Het thans voor u liggende rapport De Overijsselse arbeidsmarkt 2001-2006 en de bijgehorende Statistische Bijlage zijn door het Researchcentrum voor Onderwijs en Arbeidsmarkt (ROA) samengesteld en geven op een systematische wijze een breed overzicht van de huidige arbeidsmarktsituatie en de toekomstige arbeidsmarktontwikkelingen in Overijssel. Uit dit overzicht komen de huidige en toekomstige discrepanties naar beroep en opleiding naar voren. Daarnaast geeft Etil twee rayonrapportages uit voor IJssel-Vecht en Twente. De drie rapporten tezamen geven inhoud aan RATIO. Op basis van dit informatiesysteem kan door de Provincie Overijssel en de verschillende arbeidsmarktparticipanten in de provincie - verenigd in onder meer de RPA's - beleid geformuleerd en uitgevoerd worden. Bovendien kan de informatie gebruikt worden in het kader van de studie- en beroepskeuzevoorlichting, bijvoorbeeld voor jongeren die hun opleidingskeuze moeten bepalen.

ROA en Etil voeren reeds sinds 1997 gezamenlijk de arbeidsmarktmonitor Regionale Arbeidsmarkt Informatie Limburg (RAIL) uit, ${ }^{1}$ dat wat betreft de onderzoeksopzet als voorbeeld dient voor het project RATIO. Een soortgelijke opzet is gekozen voor het recent afgeronde project RAMING (Regionale ArbeidsMarkt Informatiesysteem Gelderland) voor de provincie Gelderland. ${ }^{2}$ Op basis van het door het ROA uitgevoerde landelijke Project Onderwijs-Arbeidsmarkt (POA) wordt reeds vanaf 1989 tweejaarlijks het rapport $D e$ arbeidsmarkt naar opleiding en beroep tot .... uitgebracht met onder meer prognoses naar opleiding en beroep voor de middellange termijn. ${ }^{3}$ Het vergelijkbare onderzoekskader van POA en RATIO en het eerder voor de provincie Gelderland uitgevoerde RAMING, maakt het mogelijk de Overijsselse arbeidsmarktontwikkelingen relatief eenvoudig af te zetten tegen de landelijke ontwikkelingen en tegen de ontwikkelingen in het naburige Gelderland.

Door zowel de huidige situatie als de toekomstige ontwikkelingen te beschrijven, heeft RATIO een signaleringsfunctie voor diverse gebruiksdoelen. Hierbij kan gedacht worden aan het personeels- en rekruteringsbeleid van werkgevers, het initiëren en bijsturen van bij- en omscholingsprogramma's voor niet-werkende werkzoekenden, de arbeidsbemiddeling en het arbeidsmarkt- en onderwijsbeleid.

De arbeidsmarktgegevens met betrekking tot de werkzame en niet-werkzame bevolking zijn afkomstig uit de Enquête Beroepsbevolking (EBB) van het Centraal

1. Zie voor de laatste publicatie van het hoofdrapport van RAIL: F. Cörvers, B.J. Diephuis, P. van Eijs m.m.v. H. van Camp (Etil), De Limburgse arbeidsmarkt 2002-2006, ROA-R-2003/3, Maastricht, 2003 en de bijhorende Statistische Bijlage.

2. Zie F. Cörvers, B.J. Diephuis, P. van Eijs, B. Golsteyn en M. Hensen, De Gelderse arbeidsmarkt 2001-2006, ROA-R-2003/4, Maastricht en de bijhorende Statistische Bijlage.

3. Zie 'Doel en opzet van de arbeidsmarktprognoses' en de begrippenlijst in het ROA-rapport, De arbeidsmarkt naar opleiding en beroep tot 2006, ROA-R-2001/8, Maastricht. Zie verder ook F. Cörvers et al. (2002), Methodiek arbeidsmarktprognoses en -indicatoren 2001-2006, ROA-W-2002/4, Maastricht; F. Cörvers, A. de Grip and H. Heijke, Beyond manpower planning: a labour market model for the Netherlands and its forecasts to 2006, in: M. Neugart and K. Schömann (eds., 2002), Forecasting Labour Markets in OECD countries, Edward Elgar, pp. 185-223. 
Bureau voor de Statistiek (CBS). Voorts is er informatie gebruikt van de Overijsselse ROC's en AOC's in het kader van de Bekostigingstellingen van de Centrale Financiën Instellingen (Cfi/Ministerie van OCenW) en de Landbouwtellingen ${ }^{4}$ van STOAS (i.o.v. Ministerie van LNV). Verder wordt intensief gebruik gemaakt van de uitgebreide arbeidsmarktinformatie over werkzoekenden en vacatures van CWI OostNederland. De informatie over de actuele arbeidsmarktpositie van MBO-schoolverlaters is gebaseerd op gegevens uit het Schoolverlaters Informatie Systeem (SIS) van het ROA. Om de kwaliteit van deze gegevens voor Overijssel in stand te houden en vergaande uitsplitsingen naar opleidingsrichting te kunnen maken, is een verhoging van de deelname van Overijsselse ROC's en AOC's aan het Schoolverlaters Informatie Systeem noodzakelijk. De prognoses van het aantal werkzame personen naar beroep en opleiding binnen RATIO zijn (deels) gebaseerd op de prognoses van het aantal arbeidsplaatsen per bedrijfssector zoals deze door Etil zijn samengesteld. Etil gebruikt voor het doorrekenen van het prognosemodel onder meer de tellingen van het aantal arbeidsplaatsen zoals die worden vastgesteld in het Bedrijven- en Instellingen Register Overijssel (BIRO) en de landelijke ramingen van het Centraal Planbureau (CPB).

Het rapport bestaat uit zes hoofdstukken. De eerste drie hoofdstukken geven een overzicht van de huidige en toekomstige vraag- en aanbodontwikkelingen op de Overijsselse arbeidsmarkt, verbijzonderd naar bedrijfssector, beroep en opleiding. In hoofdstuk 4 worden vraag en aanbod met elkaar geconfronteerd, en wordt er ingegaan op pendel als middel om de toekomstige knelpunten op de Overijsselse arbeidsmarkt te verlichten. Hoofdstuk 5 geeft de oorzaken en gevolgen weer van de werkgelegenheidsconcentratie in Overijssel ten opzichte van de rest van Nederland (met name de Randstad), terwijl hoofdstuk 6 juist ingaat op de oorzaken en gevolgen van het niet hebben van werk. Daarbij wordt in hoofdstuk 6 bijzondere aandacht geschonken aan de arbeidsmarktpositie van de doelgroepen van het arbeidsmarktbeleid in Overijssel. Deze doelgroepen worden genoemd in de nota arbeidsmarktbeleid Participatie vraagt om werk! van de Provincie Overijssel (augustus 2002) en omvatten jongeren, ouderen, vrouwen en allochtonen.

De projectleiding van RATIO is bij het ROA in handen geweest van F. Cörvers. Aan dit hoofdrapport is bij het ROA meegewerkt door L. Borghans, S. Dijksman, B. Golsteyn, M. Hensen en B. Kriechel. S. Dijksman heeft de bijbehorende Statistische Bijlage vormgegeven.

Onze dank gaat uit naar de leden van de begeleidingscommissie van RATIO. De voorzitter van de begeleidingscommissie was dhr. N. Eshuis van de provincie Overijssel. Hij werd bijgestaan door dhr. S. Wagenaar en mevr. E. Hof, eveneens van de Provincie Overijssel. Voorts hebben de volgende personen zitting gehad in de begeleidingscommissie: dhr. B. Amelink (RPA Twente), dhr. F. van Eck (RPA IJsselVecht), dhr. P. Mollink (CWI Oost-Nederland), dhr. I. te Winkel (VNO/NCW),

4. Opgemerkt dient te worden dat de gegevens van de gediplomeerden in de landbouwopleidingen van het VMBO en het MBO in het kalenderjaar 2000 alleen betrekking hebben op de gediplomeerden die niet in het onderwijs doorstromen. 
mevr. M.Topçu (FNV), dhr. H. Kloosterboer (SEACO), dhr. J. van Rhee (ROC OostNederland, ROC Twente Plus) en dhr. H. de Boer (ROC Deltion College). 



\section{Resumé}

\section{Meeste werkgelegenheid in dienstensectoren}

- Ongeveer tweederde van de werkgelegenheid ${ }^{5}$ in Overijssel bevindt zich in de dienstensectoren. Ten opzichte van Nederland zijn er in Overijssel relatief veel werkenden in de industriële sectoren Overige industrie (waaronder textiel-, hout-, paperindustrie en grafische industrie) en Metaal en elektrotechniek. Daarnaast bieden de sectoren Landbouw en visserij en Energie relatief veel werkgelegenheid in Overijssel. Van belang is verder dat de werkgelegenheid in de Landbouw en visserij en de Chemie de laatste jaren is gedaald, terwijl de werkgelegenheid in de dienstensectoren - conform de landelijke trend - over het algemeen is gestegen.

- Wat betreft de kenmerken van de werkgelegenheid valt het op dat in Overijssel procentueel minder vrouwen en ouderen, en meer jongeren werkzaam zijn dan in Nederland. Het aandeel flexibele arbeidskrachten in de werkzame beroepsbevolking is iets hoger in Overijssel, hetgeen mogelijk samenhangt met het grotere aandeel jongeren in Overijssel. Werkenden met een middelbare beroepsopleiding (MBO) sterk zijn vertegenwoordigd in de Overijsselse beroepsbevolking. Dit geldt in iets mindere mate voor de werkenden met een lagere beroepsopleiding (VMBO). Voorts maken er relatief weinig academici deel uit van de Overijsselse beroepsbevolking.

\section{Voortgaande verslechtering van de arbeidsmarktsituatie}

- Op macroniveau is de werkloosheid de resultante van de ontwikkeling van vraag en aanbod op de arbeidsmarkt. In 1994 bereikte de werkloosheid een hoogtepunt. Maar liefst $9 \%$ procent van de beroepsbevolking in Overijssel was toen werkloos. In 1996 daalde het Overijsselse werkloosheidspercentage onder het landelijke percentage. In 2001 werd voorlopig het laagste werkloosheidspercentage $(3,1 \%)$ bereikt. In 2002 steeg de werkloosheid in Overijssel voor het eerst sinds 1994. Het aantal werklozen nam tussen 2001 en 2002 met gemiddeld ongeveer 4.000 personen toe. Deze toename van de werkloosheid heeft plaatsgevonden ondanks dat het arbeidsaanbod slechts gering is gestegen: sinds 1994 was de groei van de arbeidsparticipatie niet meer zo laag.

- Over het algemeen is er een aanbodoverschot van direct bemiddelbaren op het voor hen relevante arbeidsmarktsegment (peilmaand april 2003). Alleen de bedrijfssectoren Voeding, Transport en communicatie en Kwartaire diensten vormen een uitzondering. Voor de bedrijfssector Voeding zijn er echter voldoende niet-werkende werkzoekenden beschikbaar met een grotere afstand tot de

5. De definities van werkgelegenheid en werkloosheid is conform de CBS-definities van de werkzame en werkloze beroepsbevolking, tenzij anders is aangegeven. Zie onder potentiële beroepsbevolking in de Verklarende woordenlijst van dit rapport. 
arbeidsmarkt; het aansluitingsprobleem in de arbeidsmarktsegmenten voor deze sector is derhalve meer kwalitatief dan kwantitatief van aard.

- Uit de gegevens van het najaar van 2002 blijkt dat er wat betreft werkloosheid onder MBO-schoolverlaters nauwelijks verschil bestaat tussen Overijssel en Nederland. Verder is het bruto maandloon van schoolverlaters in Overijssel iets lager dan landelijk. De mate waarin schoolverlaters een baan vinden die aansluit bij hun opleidingsniveau en opleidingsrichting verschilt niet van Nederland. Overijsselse schoolverlaters werken wel minder in deeltijd, en hebben vaker een vaste baan vergeleken met het gemiddelde van schoolverlaters in Nederland.

- De verwachting voor 2004 is dat de werkgelegenheid in Overijssel met gemiddeld $0,2 \%$ krimpt. Dit gemiddelde is een resultante van de verwachte werkgelegenheidsontwikkeling in de verschillende bedrijfssectoren. De krimp wordt met name veroorzaakt door de sectoren Landbouw, Energie, Bouw en onroerend goed en de industriële sectoren. De verwachte werkgelegenheidskrimp in de bedrijfssector Landbouw bedraagt op de korte termijn 1,6\%. Als gevolg van de conjunctuur is er eveneens een krimp te verwachten voor de bedrijfssector Bouw en onroerend goed van $0,7 \%$, en voor de verschillende industriesectoren van $1,1 \%$ tot $1,8 \%$. Dat de krimp van de werkgelegenheid beperkt blijt tot $0,2 \%$ beperkt blijft is te danken aan de verwachte groei in de sectoren Bank- en verzekeringswezen en Overheid en onderwijs met ieder 0,6\%. Horeca en zakelijke dienstverlening evenals de Kwartaire diensten vertonen een groei van $0,5 \%$.

- In 2004 wordt voor Overijssel een ruimere arbeidsmarkt voorzien ten opzichte van de huidige arbeidsmarktsituatie. Het verwachte vraagtekort in 2004 kan zich voor een deel vertalen in een oplopende werkloosheid, maar ook in dalende lonen waardoor de daling van de vraag naar personeel wordt afgeremd. Werkzoekenden kunnen behalve een langere zoekduur accepteren om een baan te vinden, ook andere concessies doen zoals het accepteren van een baan met slechtere arbeidsvoorwaarden, het accepteren van een baan die minder goed aansluit bij de eigen opleidings- en ervaringsachtergrond, en eventuele om- en bijscholingskosten, hogere reiskosten en verhuiskosten.

\section{Terugkeer van de arbeidsmarktkrapte op middellange termijn}

- De groeiverwachtingen op de korte termijn verschillen duidelijk van de verwachtingen van de middellange termijn. Ook al manifesteert de krimp van de sectoren Landbouw en visserij, Voeding, Chemie, Metaal en elektrotechniek, Overige industrie, Energie, en Bouw en onroerend goed zich over de hele middellange termijn, toch overheerst de groei in de andere sectoren. Met name de Horeca en zakelijke dienstverlening, de Kwartaire diensten, en Overheid en onderwijs zijn van groot belang voor de werkgelegenheidsgroei. Hieruit blijkt dat de verdienstelijking van de werkgelegenheid zich ook in Overijssel verder voortzet. In totaal wordt een gemiddelde jaarlijkse groei van $0,4 \%$ verwacht voor 
de periode van 2001 tot 2006. Dit komt neer op een gemiddelde jaarlijkse uitbreidingsvraag van 2.050 werkenden.

- In 2006 wordt voor zowel Overijssel als Nederland een vraagoverschot voorzien ten opzichte van de situatie in het basisjaar 2001. Het vraagoverschot geeft een indicatie van de verwachte toekomstige kwantitatieve discrepantie op de arbeidsmarkt. Op de verschillende segmenten van de Overijsselse arbeidsmarkt kunnen zich tevens uiteenlopende kwalitatieve discrepanties voordoen, waarbij met name de aansluiting tussen beroep en opleiding van belang is.

\section{Landbouw en natuurlijke omgeving populair in het beroepsonderwijs}

- Het aantal VMBO-leerlingen is in 2001 hoger dan in 2000. Het overgrote deel (meer dan 72.000 leerlingen) volgt de theoretische leerweg of zit in de eerste twee jaar van de opleiding (de zogenaamde basisvorming). Het aantal leerlingen in VMBO Theorie is gedaald ten opzichte van 2001. De stijging van het aantal leerlingen in het VMBO is te danken aan een stijging binnen de overige VMBO sectoren. De grootste stijging kent VMBO Landbouw en natuurlijke omgeving. Het aantal leerlingen in deze sector is van 1.200 naar 2.875 gestegen. Het aantal leerlingen in het MBO is ook licht gestegen. De grootste procentuele stijging vindt plaats binnen MBO Landbouw en natuurlijke omgeving. Het aantal leerlingen in de overige sectoren verschuift nauwelijks. De sector $M B O$ Economie is met bijna 13.000 leerlingen het grootst. In populariteit groeiende opleidingen zijn MBO ICT, $M B O$ verpleging, en $M B O$ administratie en logistiek. Ongeveer $37 \%$ van de Overijsselse MBO'ers volgt een opleiding volgens de meer praktisch georiënteerde beroepsbegeleidende leerweg.

- Bijna 12.000 VMBO'ers hebben hun opleiding in 2001 succesvol afgerond. Hiermee is het aantal gediplomeerden ongeveer 200 hoger dan in het jaar ervoor. 11.900 MBO'ers hebben in 2001 hun diploma gehaald. Dit is ongeveer 175 meer dan in het jaar ervoor. De meeste Overijsselse MBO'ers hebben een opleiding in de sector MBO Economie gevolgd. In deze sector is er echter wel sprake van een lichte afname van het aantal gediplomeerden. De sterkst groeiende sector ten opzichte van het jaar 2000 is MBO Dienstverlening en gezondheidszorg. Ongeveer $37 \%$ van de gediplomeerden heeft een opleiding in de beroepsbegeleidende leerweg (BBL) gevolgd. Het aandeel BBL'ers is het grootst in de sector MBO Techniek, waar ruim $66 \%$ van de gediplomeerden heeft gekozen voor een beroepsbegeleidend traject. In de sector MBO Economie daarentegen heeft ongeveer $82 \%$ van de gediplomeerden een opleiding in de beroepsopleidende leerweg (BOL) gevolgd.

- De verwachte arbeidsmarktinstroom van schoolverlaters als percentage van de werkgelegenheid schommelt voor de meeste lagere en middelbare opleidingssectoren rond de 5\%. In 2004 zijn er naar verwachting vier belangrijke uitschieters naar boven: VMBO Landbouw en natuurlijke omgeving, HAVO/VWO, MBO Landbouw en natuurlijke omgeving en MBO Techniek. Voor de middellange 
termijn (tot 2006) laten behalve de drie eerstgenoemde opleidingssectoren ook VMBO Economie een relatief grote arbeidsmarktinstroom zien.

\section{Arbeidsmarktperspectieven voor schoolverlaters redelijk tot goed}

- Over het algemeen zijn de toekomstige arbeidsmarktperspectieven voor schoolverlaters redelijk tot goed. Op de middellange termijn hebben vooral schoolverlaters met een opleiding binnen (V)MBO Techniek en (V)MBO Economie de beste arbeidsmarktperspectieven. De opleidingsrichting is blijkbaar meer bepalend voor het arbeidsmarktperspectief dan het opleidingsniveau. Schoolverlaters van opleidingen binnen VMBO Landbouw en MBO Landbouw kunnen daarentegen op de middellange termijn problemen verwachten bij het vinden van een baan, mede door de verwachte hoge arbeidsmarktinstroom. Hetzelfde geldt voor VMBO Verzorging en MBO Dienstverlening en verzorging. Schoolverlaters met een dergelijke opleidingsachtergrond zullen niet alleen op de korte termijn geconfronteerd worden met een ongunstige arbeidsmarktsituatie, maar ook op de middellange termijn zullen zij hiervan hinder ondervinden.

- De arbeidsmarktperspectieven van schoolverlaters zonder een startkwalificatie voor de arbeidsmarkt (Basisonderwijs en VMBO) lijken over het algemeen beter te zijn dan voor schoolverlaters met een MBO-diploma, met name vanwege de relatief grote vervangingsvraag. Het perspectief is echter toch niet zo rooskleurig als het lijkt. De banen waarin zij instromen bieden weinig carrièreperspectief en zijn relatief vaak tijdelijk van aard of voor een beperkt aantal uren per week. Daardoor besluiten zij vaak om niet meer te participeren op de arbeidsmarkt, en ontstaat er weer vervangingsvraag naar nieuwe jonge schoolverlaters zonder diploma of met hooguit een VMBO-diploma. Degenen die wel op de arbeidsmarkt blijven volgen vaak een postinitiële opleiding op VMBO- respectievelijk MBOniveau. Door hun doorstroom op de arbeidsmarkt ontstaat ook vervangingsvraag naar ongeschoolden en VMBO'ers.

- De uitwijkmogelijkheden geven een indicatie van de mogelijkheden die schoolverlaters hebben - mochten de kansen op de arbeidsmarkt in het eigen beroependomein gering zijn - om uit te wijken naar andere beroepen. Zowel in Nederland als Overijssel zijn er wat betreft de uitwijkmogelijkheden aanzienlijke verschillen tussen de onderwijssectoren binnen het VMBO en MBO. Ten opzichte van de rest van Nederland zijn de uitwijkmogelijkheden in Overijssel veel groter. Dit kan duiden op een gevarieerdere beroepenstructuur in Overijssel.

Grootste knelpunten in de personeelsvoorziening voor Pedagogische en Sociaalculturele beroepen

- Voor 2004 kunnen grote knelpunten in de personeelsvoorziening voor werkgevers verwacht worden in de Pedagogische beroepen, Medische en paramedische beroepen en de Sociaal-culturele beroepen. Bij de Pedagogische beroepen wordt dit veroorzaakt door de erg lage instroom van schoolverlaters vergeleken met de hoge vervangingsvraag. Voor de middellange termijn (tot 
2006) zijn er in de meeste beroepsklassen enige rekruteringsproblemen te verwachten. Bij de Pedagogische beroepen en Sociaal-culturele beroepen zijn de knelpunten het grootst. Voor de Technische en industrieberoepen, Transportberoepen en de Verzorgende en dienstverlenende beroepen hoeft men vrijwel geen knelpunten in de personeelsvoorziening te verwachten.

\section{Pendelstromen vooral in noord-zuid en oost-west richting}

- Aanpassingen van de pendelstromen van werkenden kunnen bijdragen aan een verlichting van de knelpunten op regionale arbeidsmarkten. Overijssel heeft vooral met Gelderland en Utrecht een negatief pendelsaldo. Dit betekent dat veel mensen vanuit Overijssel naar deze provincies gaan om te werken. Naast een noord-zuid beweging is er een oost-west gerichte pendelstroom, met een negatief pendelsaldo met de noordelijke provincies en een negatief pendelsaldo met de westelijke en zuidelijke provincies. Wat betreft de pendelstromen is Gelderland veruit de belangrijkste provincie voor Overijssel. Door de uitgaande pendelstromen vanuit Overijssel naar Gelderland te verkleinen of door de inkomende pendelstromen te vergroten kunnen de knelpunten in de personeelsvoorziening voor Overijsselse werkgevers verminderd worden. Dit geldt met name voor de Culturele beroepen en de Agrarische beroepen, waarvoor op de middellange termijn de Overijsselse knelpunten naar verwachting groter zijn dan de Gelderse. Verder blijkt dat de pendelstromen vanuit Duitsland naar Overijssel de laatste jaren aanzienlijk zijn toegenomen. De uitgaande pendel vanuit Overijssel naar Duitsland is in lichte mate afgenomen. Binnen Overijssel is met name Twente verantwoordelijk voor de pendel met Duitsland.

\section{Werkgelegenheidsconcentratie van invloed op productiviteit en mobiliteit}

- Er zijn redenen om aan te nemen dat zowel de gebieden met een sterke werkgelegenheidsconcentratie als de gebieden waar de werkgelegenheid zich juist minder concentreert baat kunnen hebben bij overheidsinterventie gericht op het stimuleren van innovatieve bedrijvigheid in werkgelegenheidskernen buiten de Randstad. In de grote agglomeraties kan hierdoor de congestie verminderen, terwijl de regionale kernen waarschijnlijk meer profijt hebben van de spill-overeffecten van nieuwe innovatieve bedrijven dan de Randstad nadeel zal ondervinden van het verdwijnen ervan. In Overijssel vormen Zwolle en Twente de regionaal werkgelegenheidskernen. De neiging van bedrijven om zich in elkaars buurt te vestigen duidt erop dat de spill-over-effecten tussen bedrijven productiviteitsverhogend zijn. Het clusteren van werkgelegenheid blijkt positieve gevolgen te hebben voor de productiviteit en beloning, maar leidt ook tot hogere huizenprijzen en grotere woon-werkafstanden.

- Een omvangrijke stroom van de afgestudeerden met een hogere opleiding verhuist vanuit Overijssel naar de Randstad om daar een geschikte baan te vinden. Het blijkt dat de werkgelegenheid voor hoger opgeleiden een sterke neiging heeft tot geografische clustering. De consequentie hiervan is dat steeds meer hoger opgeleiden in de Randstad gaan werken. Ook in het pendelgedrag 
komt de magnetische werking van de Randstad tot uiting. Gemiddeld werken de bewoners van Overijssel ten Westen van hun woonplaats. Er is niet veel rechtstreekse pendel tussen Overijssel en de Randstad, maar de werkenden uit Overijssel worden aangezogen door de werkgelegenheid die in Gelderland ontstaat doordat mensen van daar werken in de Randstad.

- Mensen met een hoog inkomen zijn eerder geneigd verder van hun werk te gaan wonen. De kosten van het pendelen zijn voor hen relatief laag vergeleken met het de aantrekkelijkheid van met name grotere woningen buiten de stad. Het gevolg is dat juist in die gebieden waar de grootste werkgelegenheidsconcentraties te vinden zijn, relatief de meeste werklozen en mensen met een laag inkomen wonen.

- Er zijn redenen om aan te nemen dat zowel de gebieden met een sterke werkgelegenheidsconcentratie als de gebieden waar de werkgelegenheid zich juist minder concentreert, baat kunnen hebben bij overheidsinterventie gericht op het stimuleren van innovatieve bedrijvigheid in werkgelegenheidskernen buiten de Randstad. In de grote agglomeraties kan hierdoor de congestie verminderen, terwijl de regionale kernen waarschijnlijk meer profijt hebben van de spill-overeffecten van nieuwe innovatieve bedrijven dan de Randstad nadeel zal ondervinden van het verdwijnen ervan.

\section{Onbenutte arbeidspotentieel is aanzienlijk gedaald}

- Het onbenutte arbeidspotentieel van Overijssel omvat 191.500 personen die niet werken (gemiddelde 2001-2002), van wie 106.000 personen geen betaald werk willen verrichten. Binnen het onbenutte arbeidspotentieel zijn alleen de 15.000 werklozen actief op zoek naar werk. Voor het verlichten van de knelpunten op de arbeidsmarkt zijn daarnaast de 19.000 niet-participerenden van belang die weliswaar niet actief zoeken naar werk maar wel beschikbaar zijn voor de arbeidsmarkt. De overige niet-participerenden zijn niet beschikbaar voor de arbeidsmarkt, en vormen veruit de grootste groep binnen het onbenutte arbeidspotentieel.

- Het onbenutte arbeidspotentieel is tussen 1993-1994 en 2001-2002 met ongeveer 44.000 personen in aantal gedaald. De opgaande conjunctuur en de voortdurende stijging van het opleidingsniveau hebben hierbij een belangrijke rol gespeeld. Het aantal werklozen is in deze periode gehalveerd. Binnen het onbenutte arbeidspotentieel is het aantal personen dat aangeeft niet te willen werken absoluut gezien het meest gedaald.

\section{Terugkeer naar de arbeidsmarkt is moeilijk}

- Juist daar waar de knelpunten in de personeelsvoorziening voor werkgevers het grootste zijn, namelijk op HBO- en WO-niveau, is het aantal werklozen en beschikbare niet-participerenden relatief het kleinst. Naast de opleidingsachtergrond speelt de relevante werkervaring vaak een nog belangrijkere rol voor 
werklozen en herintreders om te kunnen concurreren met schoolverlaters op de arbeidsmarkt.

- Slechts $45 \%$ van het onbenutte arbeidspotentieel heeft een middelbare opleiding of hoger (een zgn. 'startkwalificatie'), tegenover $71 \%$ van de werkenden. Het gemiddelde opleidingsniveau van de werklozen is weliswaar lager dan van de werkenden maar hoger dan van de niet-participerenden. In tegenstelling tot de werkenden zijn de niet-participerenden in meerderheid vrouwen. Vooral nietwesterse allochtonen zijn vaak werkloos of niet-participerend. Zij hebben relatief vaak een lage opleidingsachtergrond. Het grootste gedeelte van de nietparticiperenden heeft geen intentie om te gaan werken en zal daarom zeer moeilijk kunnen worden gemotiveerd werk te aanvaarden.

- Vrouwen, jongeren en laaggeschoolden treden relatief vaak uit vanwege de verzorging van de kinderen of arbeidsongeschiktheid. In zowel een krappe als een ruime arbeidsmarkt geldt echter dat hoe langer men niet op arbeidsmarkt participeert, des te minder goed het carrièreverloop zal zijn bij herintrede. Voor werklozen geldt dit effect alleen bij een ruime arbeidsmarkt. Zij lijken in een krappe arbeidsmarkt nauwelijks belemmerd te worden bij het vinden van een goede baan. 



\section{De Overijsselse arbeidsmarkt in vogelvlucht}

Overijssel heeft ten opzichte van Nederland relatief veel werkenden in de industriële sectoren Overige industrie (waaronder textiel-, hout-, paperindustrie en grafische industrie) en Metaal en elektrotechniek. Daarnaast bieden de sectoren Landbouw en visserij en Energie relatief veel werkgelegenheid in Overijssel. Daarentegen zijn er relatief weinig werkenden in de commerciële dienstensectoren Bank- en verzekeringswezen, Horeca en zakelijke dienstverlening en Transport en communicatie. Van belang is verder dat de werkgelegenheid in de Landbouw en visserij en de Chemie de laatst jaren is gedaald, terwijl de werkgelegenheid in de dienstsectoren - conform de landelijke trend - over het algemeen is gestegen. Verder blijkt de werkenden met een middelbare beroepsopleiding (MBO) sterk zijn vertegenwoordigd in de Overijsselse beroepsbevolking. Dit geldt in iets mindere mate voor de werkenden met een lagere beroepsopleiding. Voorts maken er relatief weinig academici deel uit van de Overijsselse beroepsbevolking. In Overijssel zijn procentueel minder vrouwen en ouderen, en meer jongeren werkzaam dan in Nederland.

In 2002 steeg de werkloosheid in Overijssel voor het eerst sinds 1994. Het aantal werklozen nam tussen 2001 en 2002 met gemiddeld ongeveer 4.000 personen toe. Uit de gegevens van het najaar van 2002 blijkt dat er wat betreft werkloosheid onder MBO-schoolverlaters nauwelijks verschil bestaat tussen Overijssel en Nederland. Verder is het bruto maandloon van schoolverlaters in Overijssel iets lager dan landelijk. Ook de mate waarin schoolverlaters een baan vinden die aansluit bij hun opleidingsniveau en de opleidingsrichting verschilt voor Overijssel niet van Nederland. Overijsselse schoolverlaters werken wel minder in deeltijd, en hebben vaker een vaste baan vergeleken met het gemiddelde van schoolverlaters in Nederland.

Alleen de arbeidsmarktsegmenten die relevant zijn voor de bedrijfssectoren Voeding, Transport en communicatie en Kwartaire diensten hadden in april 2003 meer openstaande vacatures dan direct bemiddelbare niet-werkende werkzoekenden. Voor de bedrijfssector Voeding is dit tekort vooral een kwalitatief aansluitingsprobleem, voor de twee laatstgenoemde bedrijfssectoren is het tekort kwantitatief van aard. In 2004 wordt voor Overijssel een ruimere arbeidsmarkt voorzien dan de huidige arbeidsmarktsituatie. Het verwachte vraagtekort in 2004 kan zich voor een deel vertalen in een oplopende werkloosheid, maar ook in dalende lonen waardoor de daling van de vraag naar personeel wordt afgeremd. In 2006 wordt voor zowel Overijssel als Nederland een vraagoverschot voorzien ten opzichte van de situatie in het basisjaar 2001.

Voor ongeschoolden en in iets mindere mate ook voor de verschillende VMBOopleidingsrichtingen lijkt het perspectief gunstig te zijn, zij het dat deze schoolverlaters zonder startkwalificatie veelal in zogenaamde 'dead-end jobs' terecht komen onder relatief slechte arbeidsvoorwaarden en zonder veel carrièreperspectief. Zonder adequate omscholing dreigt er voor hen op termijn uittrede van de arbeidsmarkt en non-participatie. De arbeidsmarktperspectieven voor schoolverlaters van 
MBO Economie in Overijssel zijn zowel op de korte als de middellange termijn goed. Voor MBO Techniek geldt dit alleen voor de middellange termijn, omdat er in 2004 een relatief grote arbeidsmarktinstroom van schoolverlaters met een diploma van een middelbare technische beroepsopleiding wordt verwacht. Voor 2004 zijn de knelpunten in de personeelsvoorziening naar verwachting groot voor de Pedagogische beroepen, de Sociaal-culturele beroepen, en de Medische en paramedische beroepen. In 2006 worden in Overijssel alleen grote knelpunten in de personeelsvoorziening verwacht voor de twee eerstgenoemde beroepsklassen.

\subsection{Inleiding}

In dit hoofdstuk wordt ingegaan op de werkgelegenheidsstructuur en de ontwikkelingen op de Overijsselse arbeidsmarkt. Daarbij wordt in paragraaf 1.2 eerst gekeken naar trends in de economische groei, de werkgelegenheid en de participatie op de arbeidsmarkt in Overijssel en Nederland. In paragraaf $1.3 \mathrm{komt}$ de sectorale werkgelegenheidsstructuur aan de orde. In paragraaf 1.4 wordt er aandacht besteed aan de actuele discrepanties op de arbeidsmarkt door een indicatie te geven van de vraag en het aanbod per bedrijfssector op de Overijsselse arbeidsmarkt. Voorts wordt de arbeidsmarktpositie van schoolverlaters in Overijssel in beeld gebracht. Aansluitend zal in paragraaf 1.5 worden ingegaan op de verwachte arbeidsmarktontwikkelingen op hoofdlijnen. In paragraaf 1.6 wordt ingegaan op de verwachte knelpunten en perspectieven naar beroep en opleiding op de korte en de middellange termijn.

\subsection{Groeitrends in Overijssel en Nederland}

De ontwikkeling van de werkgelegenheid in Overijssel is sterk afhankelijk van de regionale economische groei. In figuur 1.1 wordt de groei van de toegevoegde waarde in Overijssel ten opzichte van Nederland weergegeven tussen 1996 en 2002. Gedurende deze periode heeft Overijssel alleen in de jaren 2000 en 2001 een hogere economische groei gekend dan landelijk. Er is duidelijk te zien dat voor zowel Overijssel als Nederland de economische groei in 2001 en 2002 aanzienlijk is gedaald ten opzichte van de jaren ervoor. In 2002 is er in Overijssel zelfs nauwelijks economische groei geweest.

De regionale economische groei vertaalt zich op de arbeidsmarkt, met enige vertraging, in de groei van de werkgelegenheid. Een indicatie van de regionale werkgelegenheidsgroei kan worden verkregen door te kijken naar de groei van het aantal arbeidsplaatsen in Overijssel. De ontwikkeling van het aantal arbeidsplaatsen geeft een indruk van de groeitrend van de vraag naar arbeid, dat wil zeggen de groei van de inzet van de productiefactor arbeid door bedrijven, instellingen en de verschillende overheden. In combinatie met de inzet van andere productiefactoren (kapitaal, technologie, ruimte, etc.) wordt er toegevoegde waarde in de regio gegenereerd. Uit figuur 1.2 blijkt dat het aantal arbeidsplaatsen in Overijssel in 2002 is gegroeid $(0,9 \%)$, zelfs iets meer dan het Nederlandse gemiddelde. Door de vertraagde reactie van de arbeidsmarkt op de economische groei, is het te 
verwachten dat het aantal arbeidsplaatsen in Overijssel in 2003 nog nauwelijks zal groeien of zelfs zal dalen. ${ }^{6}$

\section{Figuur 1.1}

De regionale economische groei (jaarlijkse groei van het volume van de toegevoegde waarde) in procenten, Overijssel en Nederland, 1996-2002

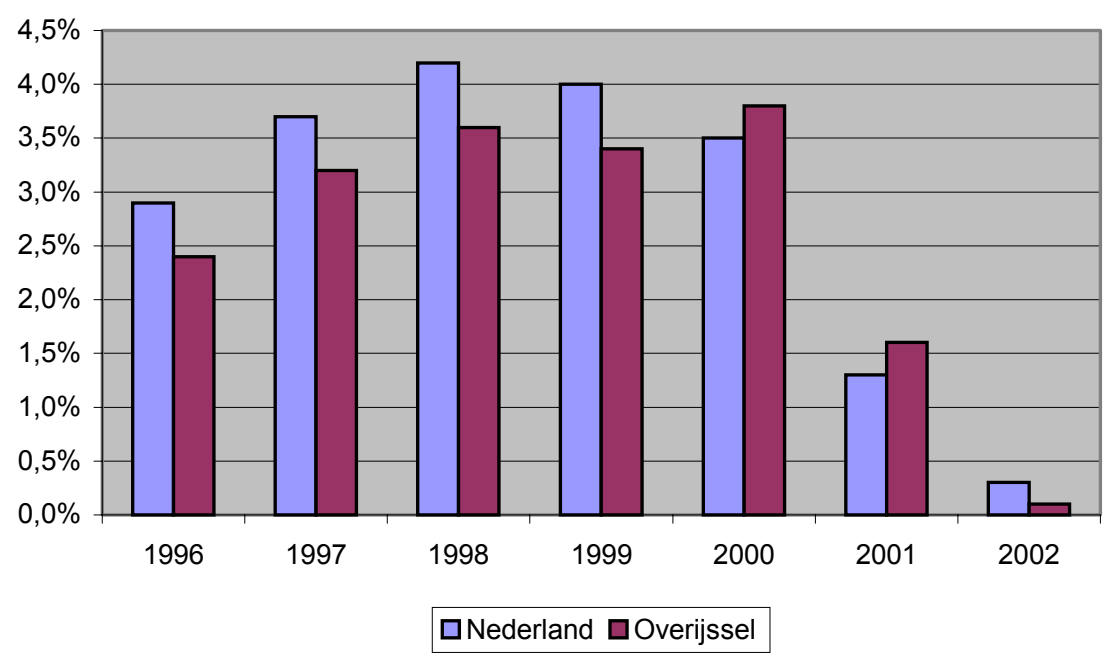

Bron: CBS

\section{Figuur 1.2}

De jaarlijkse groei van het aantal arbeidsplaatsen, Overijssel en Nederland, 1996-2002

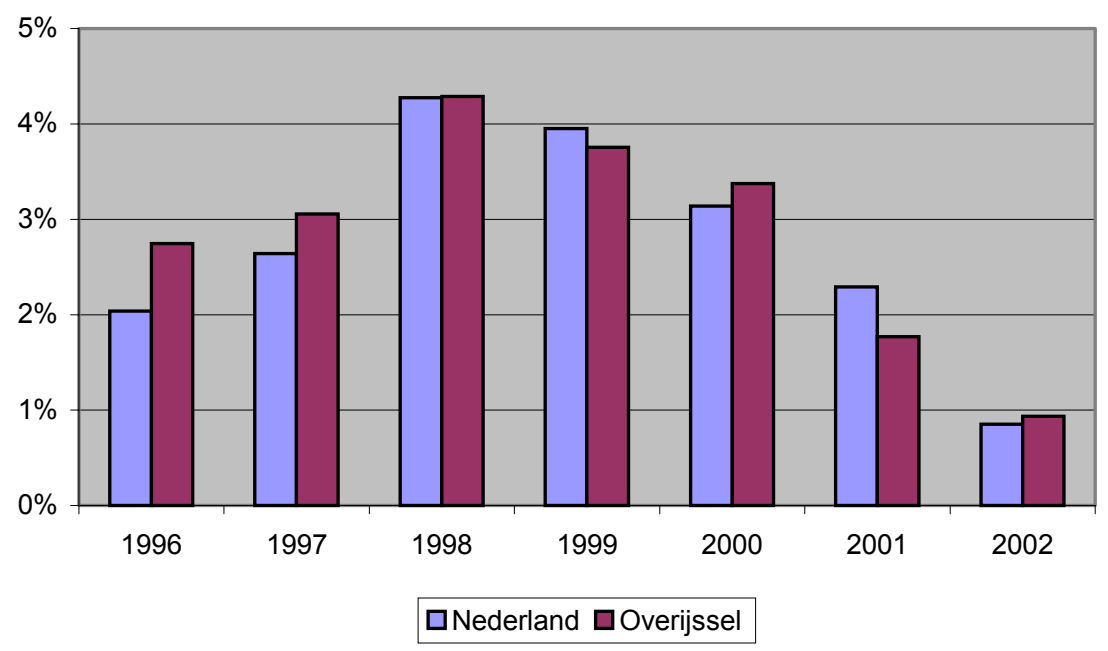

Bron: Etil

6. De prognoses van de groei van het aantal arbeidsplaatsen in Overijssel voor 2003 en 2004 zijn respectievelijk $-0,6 \%$ en $0,0 \%$ (Bron: Etil). 
Aan de aanbodzijde van de arbeidsmarkt is vooral de ontwikkeling van de bruto participatiegraad van belang. Deze geeft het aandeel van de beroepsbevolking in de totale bevolking tussen 15 en 64 jaar weer. De beroepsbevolking bestaat uit zowel de werkzame personen als de werklozen. ${ }^{7}$ Uit figuur 1.3 blijkt dat de toe- en afname van de bruto participatiegraad in Overijssel in grote lijnen de landelijke ontwikkeling volgt. Niettemin zijn de fluctuaties in de waargenomen jaarlijkse veranderingen op regionaal niveau groter dan voor Nederland. Alleen voor 2001 en 2002 lijkt de groei van het regionale aanbod achter te blijven bij de landelijke groei.

Figuur 1.3

De jaarlijkse verandering van de bruto participatiegraad (beroepsbevolking als percentage van totale bevolking tussen 15 en 64 jaar) in procentpunten, Overijssel en Nederland, 1993-2002
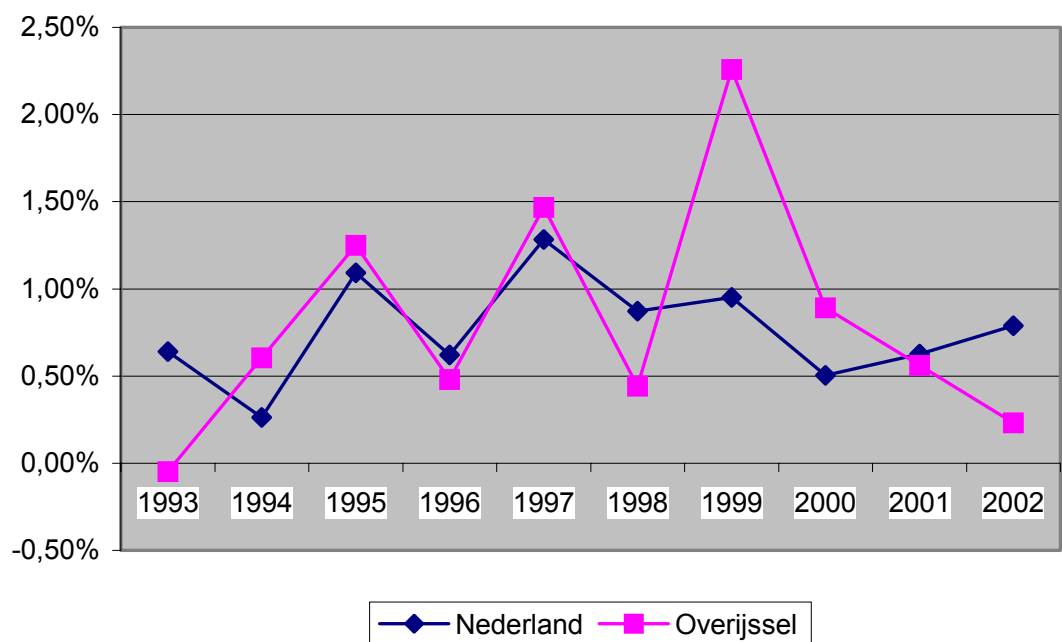

Bron: CBS

Indien de vraag- en aanbodontwikkelingen op de arbeidsmarkt van respectievelijk figuur 1.2 en figuur 1.3 met elkaar worden geconfronteerd, volgt de ontwikkeling van de verdeling van de beroepsbevolking in werkenden en werklozen over de tijd. Zo is het bijvoorbeeld te verwachten dat als de toename van de vraag naar arbeidskrachten groter is dan de toename van het aanbod, het aandeel werkzame personen in de beroepsbevolking toe zal nemen ten koste van het aandeel werklozen. ${ }^{8}$ Over het algemeen wordt de vraag naar arbeid vooral door de conjunctuurcyclus beïnvloed, terwijl het aanbod van arbeid meer afhankelijk is van de langetermijnontwikkeling van de toename van het arbeidsaanbod van vrouwen - onder invloed van veranderingen van bijvoorbeeld sociale normen, kinderopvangvoorzieningen en fiscale prikkels - en de samenstelling van de bevolking naar onder meer leeftijd, opleidingsniveau en etniciteit. ${ }^{9}$

7. Het gaat hierbij uitsluitend over personen die voor minstens 12 uur per week werkzaam (willen) zijn.

8. Hierbij spelen echter ook het aantal uren per week dat met de arbeidsplaatsen gemoeid is een rol, evenals de arbeidsduur en de productiviteit van de werkenden.

9. Vraag en aanbod op de arbeidsmarkt reageren echter ook op elkaar. Zie paragraaf 1.5. 
In figuur 1.4 is de jaarlijkse procentuele groei van het aantal werkzame personen weergegeven. Uit de figuur blijkt dat Overijssel in 1993 en 1994 getroffen werd door een afname van het aantal werkenden. Verder is de groei van het aantal werkzame personen afgenomen van bijna $5 \%$ in 1999 tot nauwelijks enige groei in 2002. Deze ontwikkeling weerspiegelt met name de afname van de groei van de vraag naar arbeid in Overijssel, zoals weergeven door de ontwikkeling van het aantal arbeidsplaatsen in figuur 1.2. De grote groei van de het aantal werkenden in 1999 hangt echter vooral samen met de sterke groei van het arbeidsaanbod in dat jaar.

Figuur 1.4

De jaarlijkse groei van het aantal werkzame personen, Overijssel en Nederland, 1993-2002

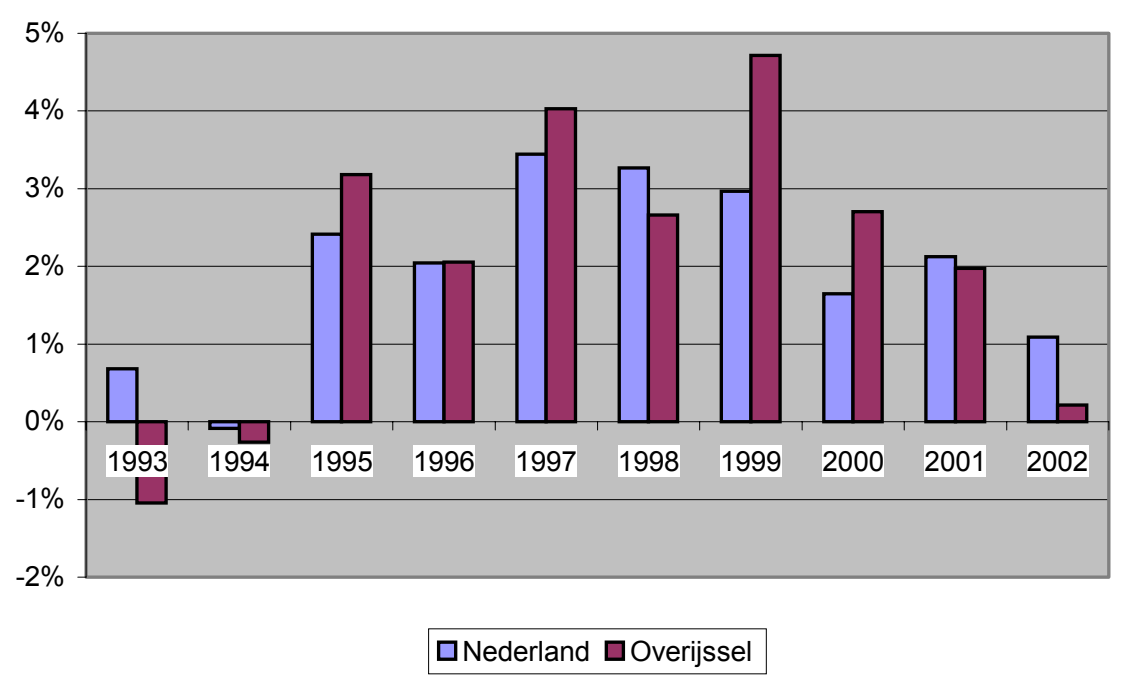

Bron: CBS

Tot slot is in figuur 1.5 het jaarlijkse werkloosheidspercentage weergegeven in Overijssel en Nederland tussen 1993 en 2002. Op macroniveau is de werkloosheid de resultante van de ontwikkeling van vraag en aanbod op de arbeidsmarkt. In 1994 bereikte de werkloosheid een hoogtepunt. Maar liefst $9 \%$ procent van de beroepsbevolking in Overijssel was toen werkloos. In 1996 daalde het Overijsselse werkloosheidspercentage onder het landelijke percentage. De figuur laat voorts zien dat er in 2001 voorlopig het laagste werkloosheidspercentage (3,1\%) werd bereikt. In 2002 steeg de werkloosheid in Overijssel voor het eerst sinds 1994 . Het aantal werklozen nam tussen 2001 en 2002 met gemiddeld ongeveer 4.000 personen toe. Deze toename van de werkloosheid heeft plaatsgevonden ondanks dat het arbeidsaanbod slechts gering is gestegen. Sinds 1994 was immers de groei van de arbeidsparticipatie niet meer zo laag (zie figuur 1.3). 
Figuur 1.5

Jaarlijkse gemiddelde werkloosheidspercentage (definitie werkloze beroepsbevolking CBS),

Overijssel en Nederland, 1993-2002

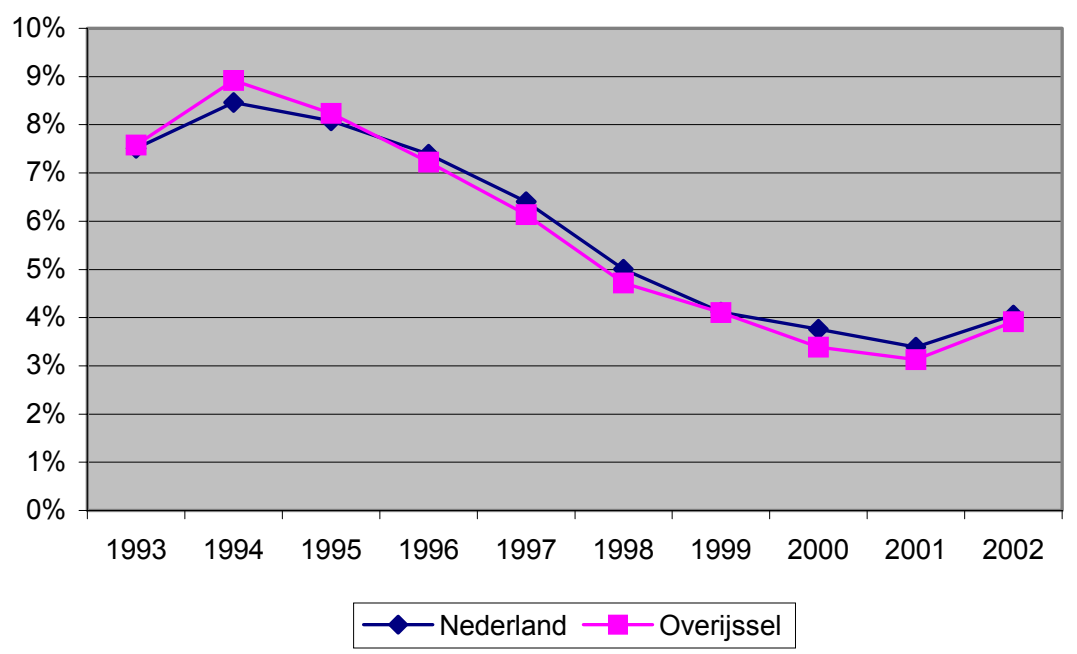

Bron: CBS

\subsection{Kenmerken en ontwikkeling van de werkzame beroepsbevolking in Overijssel}

Voor een beter inzicht in de Overijsselse werkgelegenheidsontwikkeling wordt in deze paragraaf stilgestaan bij een aantal kenmerken van de werkgelegenheid van de beroepsbevolking in Overijssel. Tabel 1.1 geeft aan in welke bedrijfssectoren de beroepsbevolking van Overijssel werkzaam is. Bovendien worden het soort aanstelling en de achtergrondkenmerken naar leeftijd en geslacht weergegeven. De grootste bedrijfssectoren zijn de dienstensectoren Handel en reparatie, Horeca en zakelijke dienstverlening (incl. uitzendwezen), Kwartaire diensten (incl. gezondheidszorg) en Overheid en onderwijs. In deze sectoren werken in totaal ongeveer een bijna 270.000 mensen, hetgeen bijna $60 \%$ de werkzame beroepsbevolking van Overijssel is. Ten opzichte van Nederland zijn er in Overijssel relatief veel werkenden in de industriële sectoren Overige industrie (waaronder textiel-, hout-, paperindustrie en grafische industrie) en Metaal en elektrotechniek. Daarnaast bieden de sectoren Landbouw en visserij en Energie relatief veel werkgelegenheid in Overijssel. Daarentegen zijn er relatief weinig werkenden in de commerciële dienstensectoren Bank- en verzekeringswezen, Horeca en zakelijke dienstverlening en Transport en communicatie. Van belang is verder dat de werkgelegenheid in de Landbouw en visserij en de Chemie de laatst jaren is gedaald, terwijl de werkgelegenheid in de dienstsectoren - conform de landelijke trend - over het algemeen is gestegen. ${ }^{10}$

10. Zie ook ROA(2001), De arbeidsmarkt naar opleiding en beroep tot 2006, ROA-R-2001/8, Maastricht. 
Tabel 1.1

Werkzame beroepsbevolking naar bedrijfssector en overige kenmerken in Overijssel, gemiddelde 2000-2001

Bedrijfssector

\begin{tabular}{|c|c|c|}
\hline $\begin{array}{r}\text { Aantal } \\
\text { werkenden }\end{array}$ & $\begin{array}{l}\text { Typering } \\
\text { t.o.v. } \\
\text { Nederland }\end{array}$ & $\begin{array}{l}\text { Trend } \\
\text { 1997-2001 }\end{array}$ \\
\hline
\end{tabular}

\begin{tabular}{|c|c|c|c|}
\hline Landbouw en visserij & 16.500 & hoog & dalend \\
\hline Voeding & 12.000 & gemiddeld & constant \\
\hline Chemie & 9.000 & gemiddeld & dalend \\
\hline Metaal en elektrotechniek & 33.000 & hoog & constant \\
\hline Overige industrie & 34.000 & zeer hoog & constant \\
\hline Energie & 4.500 & hoog & constant \\
\hline Bouw en onroerend goed & 42.000 & gemiddeld & stijgend \\
\hline Handel en reparatie & 72.000 & gemiddeld & stijgend \\
\hline Transport en communicatie & 20.500 & laag & constant \\
\hline Bank- en verzekeringswezen & 12.000 & zeer laag & stijgend \\
\hline Horeca en zakelijke dienstverlening & 59.000 & laag & stijgend \\
\hline Kwartaire diensten & 72.500 & gemiddeld & stijgend \\
\hline Overheid en onderwijs & 65.000 & gemiddeld & stijgend \\
\hline Totaal (incl. overig) & 460.000 & - & stijgend \\
\hline Leeftijd & $\begin{array}{r}\text { Overijssel } \\
\%\end{array}$ & $\begin{array}{r}\text { Nederland } \\
\%\end{array}$ & $\begin{array}{l}\text { Trend } \\
\text { 1997-2001 }\end{array}$ \\
\hline Jongeren (15-29) & 28 & 25 & constant \\
\hline Ouderen (50-64) & 18 & 19 & constant \\
\hline Geslacht & $\begin{array}{r}\text { Overijssel } \\
\%\end{array}$ & $\begin{array}{r}\text { Nederland } \\
\%\end{array}$ & $\begin{array}{l}\text { Trend } \\
\text { 1997-2001 }\end{array}$ \\
\hline Vrouwen & 38 & 40 & constant \\
\hline Contract & $\begin{array}{r}\text { Overijssel } \\
\%\end{array}$ & $\begin{array}{r}\text { Nederland } \\
\%\end{array}$ & $\begin{array}{l}\text { Trend } \\
\text { 1997-2001 }\end{array}$ \\
\hline Flexibel werk & 9 & 8 & dalend \\
\hline Deeltijdwerk & 31 & 31 & stijgend \\
\hline Zelfstandigen & 11 & 11 & constant \\
\hline
\end{tabular}

Bron: CBS/ROA

Wat betreft de kenmerken van de werkgelegenheid naar leeftijd, geslacht en soort aanstelling valt het op dat in Overijssel procentueel minder vrouwen en ouderen, en meer jongeren werkzaam zijn dan in Nederland. Het aandeel flexibele arbeidskrachten in de werkzame beroepsbevolking is iets hoger in Overijssel, hetgeen mogelijk samenhangt met het grotere aandeel jongeren in Overijssel.

In tabel 1.2 is de werkzame beroepsbevolking naar beroep en opleiding weergegeven. Hieruit blijkt wederom dat Overijssel relatief veel werkenden in de agrarische sector heeft. Ook de Technische en industrieberoepen zijn oververtegenwoordigd. 
Daarentegen zijn de beroepsklassen die vaak voorkomen in de commerciële diensten, zoals de Informaticaberoepen, ondervertegenwoordigd. Verder blijkt uit tabel 1.2 dat de werkenden met een middelbare beroepsopleiding (MBO) sterk zijn vertegenwoordigd in de Overijsselse beroepsbevolking. Dit geldt in iets mindere mate voor de werkenden met een lagere beroepsopleiding (VMBO). Voorts maken er relatief weinig academici deel uit van de Overijsselse beroepsbevolking.

Tabel 1.2

Werkzame beroepsbevolking naar beroep en opleiding in Overijssel, gemiddelde 2000-2001

Beroepsklasse

$\begin{array}{rll}\text { Aantal } & \text { Typering } & \text { Trend } \\ \text { werkenden } & \text { t.o.v. } & \text { 1997-2001 } \\ & \text { Nederland } & \end{array}$

\begin{tabular}{lrll}
\hline & & & \\
Pedagogische beroepen & 28.000 & hoog & stijgend \\
Culturele beroepen & 7.500 & laag & stijgend \\
Agrarische beroepen & 21.000 & zeer hoog & constant \\
Technische, ambachts en industrie beroepen & 119.000 & hoog & constant \\
Transport beroepen & 24.500 & gemiddeld & constant \\
Medische en paramedische beroepen & 22.500 & gemiddeld & constant \\
Economisch-administratieve beroepen & 113.500 & laag & constant \\
Informatica beroepen & 13.000 & zeer laag & stijgend \\
Sociaal-culturele beroepen & 14.500 & gemiddeld & stijgend \\
Verzorgende en dienstverlenende beroepen & 78.000 & gemiddeld & stijgend \\
Openbare orde en veiligheidsberoepen & 7.000 & gemiddeld & stijgend \\
Totaal (incl overig) & 460.000 & - & stijgend \\
& & & \\
\hline & & & \\
Opleidingsniveau & Overijssel & Nederland & Trend \\
& $\%$ & $\%$ & $1997-2001$ \\
& & & \\
& & & \\
Basisonderwijs & 35.000 & gemiddeld & stijgend \\
VMBO Theorie & 25.500 & gemiddeld & constant \\
VMBO & 71.000 & hoog & stijgend \\
HAVO/VWO & 22.500 & laag & sterk stijgend \\
MBO & 190.500 & zeer hoog & constant \\
HBO & 80.000 & gemiddeld & constant \\
WO & 23.500 & zeer laag & stijgend \\
Totaal (incl. overig) & 460.000 & - & stijgend \\
& & &
\end{tabular}

Bron: CBS/ROA

\subsection{Actuele arbeidsmarktdiscrepanties in Overijssel}

Actuele arbeidsmarktdiscrepanties kunnen worden weergegeven door vacatures en werkzoekenden aan elkaar te relateren. In tabel 1.3 wordt per bedrijfstak in Overijssel een indicator voor de arbeidsmarktkrapte weergegeven. Het begrip arbeidsmarktkrapte dat in deze rapportage gehanteerd wordt, is gedefinieerd als de verhouding tussen het aantal openstaande vacatures en het aantal niet-werkende werkzoekenden in bemiddelingsfase 1 per arbeidsmarktsegment. Bemiddelingsfase 1 heeft betrekking op werkzoekenden voor wie arbeidsmarktinstrumenten beschikbaar zijn gericht op directe bemiddeling of terugkeer naar de arbeidsmarkt. Een hogere bemiddelingsfase impliceert een grotere afstand tot de arbeidsmarkt. (zie ook de Verklarende woordenlijst). Aangezien werkzoekenden niet naar bedrijfssector 
ingedeeld kunnen worden, kan deze maatstaf in eerste instantie niet direct gebruikt worden om de arbeidsmarktkrapte naar bedrijfssector te berekenen. De arbeidsmarktkrapte naar bedrijfssector is daarom gedefinieerd als het gewogen gemiddelde van de arbeidsmarktkrapte naar beroepsgroep (zie verder hoofdstuk 3 van de Statistische Bijlage). De wegingsfactor is daarbij gebaseerd op het aandeel van de betreffende beroepsgroep in het totale aantal openstaande vacatures in die bedrijfssector. Hoe hoger de arbeidsmarktkrapte in een bedrijfssector, hoe groter de rekruteringsproblemen.

Wanneer de indicator voor de arbeidsmarktkrapte kleiner is dan één, is er sprake van een aanbodoverschot van direct bemiddelbaren op het voor hen relevante arbeidsmarktsegment. Dit blijkt voor de meeste bedrijfssectoren in tabel 1.3 het geval te zijn. Alleen de bedrijfssectoren Voeding, Transport en communicatie en Kwartaire diensten vormen een uitzondering. ${ }^{11} \mathrm{De}$ indicator voor de arbeidsmarktkrapte voor Overijssel als geheel is eveneens groter dan één, hetgeen impliceert dat er sprake is van een tekort aan direct inzetbare niet-werkende werkzoekenden ten opzichte van het aantal openstaande vacatures in het voor hen relevante arbeidsmarktsegment.

Een tekort van direct inzetbare niet-werkenden werkzoekenden kan twee oorzaken hebben: wanneer het aanbod getalsmatig tekortschiet is er sprake van een kwantitatief probleem. In dat geval is de zogenaamde knelpuntindicator, die in de laatste kolom van tabel 1.3 wordt weergegeven, groter dan één. Deze knelpuntindicator is in deze rapportage gedefinieerd als de verhouding tussen het aantal openstaande vacatures dat niet door niet-werkende werkzoekenden in bemiddelingsfase 1 vervuld kan worden en het aantal niet-werkende werkzoekenden in bemiddelingsfase 2 en 3 . Deze bemiddelingsfasen duiden op werkzoekenden die weliswaar bemiddelbaar zijn (in tegenstelling tot fase 4), maar waarbij het bemiddelingstraject - bijvoorbeeld vanwege het volgen van cursussen - een jaar of langer kan gaan duren. Hoe hoger de knelpuntindicator, hoe minder niet-werkende werkzoekenden met een grotere afstand tot de arbeidsmarkt er beschikbaar zijn voor de openstaande vacatures die niet door direct bemiddelbare werkzoekenden vervuld kunnen worden. Met name voor Transport en communicatie, maar ook voor Kwartaire diensten is de knelpuntindicator veel groter dan één. Dit impliceert tevens dat werkzoekenden (in fase 2 en 3 ) in de betreffende arbeidsmarktsegmenten van deze bedrijfssectoren de mogelijkheid hebben via bijscholing de kansen op een baan te vergroten.

Wanneer het probleem vooral gelegen is in het feit dat het percentage niet-werkende werkzoekenden in fase 1 relatief laag is, is dit tekort vooral een kwalitatief aansluitingsprobleem dat zich zal manifesteren in een knelpuntindicator kleiner dan één. Er zijn dan meer werkzoekenden dan vacatures die resteren als alle direct inzetbare werkzoekenden (fase 1) worden bemiddeld. Dit blijkt met name het geval te zijn voor de arbeidsmarktsegmenten in relatie tot de bedrijfssector Voeding. Voor de arbeids-

11. Van belang is dat de vacature- en werkzoekendengegevens niet zijn gecorrigeerd voor seizoensinvloeden. Met name voor de Landbouw en de Horeca kan dat van grote invloed zijn. 
marktsegmenten van deze bedrijfssector zijn er derhalve voldoende werkzoekenden in fase 2 en 3, die echter niet direct inzetbaar zijn op de openstaande vacatures.

Voor de meeste bedrijfssectoren geldt dat het aantal niet-werkende werkzoekenden in fase 1 het aantal openstaande vacatures overtreft, waardoor de indicator voor de arbeidsmarktkrapte kleiner is dan één en de knelpuntindicator gelijk is aan nul. Er is dan geen sprake van een tekort aan gekwalificeerd aanbod. Het aantal vacatures schiet dan juist tekort om alle direct inzetbare werkzoekenden aan werk te helpen.

Tabel 1.3

Krapte op de Overijsselse arbeidsmarkt per bedrijfssector ${ }^{*}$, april 2003

$\begin{array}{lclc}\text { Bedrijfssector } & \text { Arbeidsmarktkrapte } & \text { Typering } & \text { Knelpuntindicator } \\ & & & \\ & & & \\ \text { Landbouw en visserij } & 0,28 & \text { zeer laag } & 0,00 \\ \text { Voeding } & 1,30 & \text { hoog } & 0,27 \\ \text { Chemie } & 0,35 & \text { laag } & 0,00 \\ \text { Metaal en elektrotechniek } & 0,47 & \text { laag } & 0,00 \\ \text { Overige industrie } & 0,63 & \text { gemiddeld } & 0,00 \\ \text { Energie } & - & - & - \\ \text { Bouw en onroerend goed } & 0,53 & \text { laag } & 0,00 \\ \text { Handel en reparatie } & 0,62 & \text { gemiddeld } & 0,00 \\ \text { Transport en communicatie } & 6,76 & \text { zeer hoog } & 4,46 \\ \text { Bank- en verzekeringswezen } & 0,55 & \text { gemiddeld } & 0,00 \\ \text { Horeca en zakelijke dienstverlening } & 0,32 & \text { zeer laag } & 0,00 \\ \text { Kwartaire diensten } & 3,29 & \text { hoog } & 1,82 \\ \text { Overheid en onderwijs } & 0,57 & \text { gemiddeld } & 0,00 \\ & & & \end{array}$

*) Zie de bijgaande tekst en de Verklarende woordenlijst voor uitleg over de gebruikte indicatoren.

Bron: CBS/CWI/Etil/ROA

Arbeidsmarktdiscrepanties kunnen zich echter in meer dimensies uiten dan in slechts vacatures en werkloosheid. Andere indicatoren met betrekking tot de aansluiting tussen opleiding en beroep geven meer inzicht in bestaande discrepanties op de arbeidsmarkt. Zo kunnen goed opgeleide arbeidskrachten onder hun niveau werkzaam zijn of buiten de gewenste vakrichting, waardoor tevens de productiviteit en het loon achterblijven bij wat elders op de arbeidsmarkt zou kunnen worden behaald. Ook kunnen werkenden tegen hun zin genoegen moeten nemen met een tijdelijke aanstelling of een deeltijdaanstelling. Door te kijken naar de positie van starters op de arbeidsmarkt in Overijssel ten opzichte van Nederland kan een beeld worden verkregen van de ernst van de regionale arbeidsmarktdiscrepanties. In tabel 1.4 wordt dit gedaan voor gediplomeerde schoolverlaters van het MBO anderhalf jaar na het afronden van hun opleiding. In de tabel wordt onderscheid gemaakt tussen enerzijds 'open discrepanties' zoals de werkloosheid onder schoolverlaters en het bruto maandloon dat ze verdienen, en anderzijds 'verborgen discrepanties' zoals het moeten werken in deeltijd of in een flexibele aanstelling (korter dan één jaar, uitzendwerk), of het verrichten van werk onder het opleidingsniveau (onderbenutting) of buiten de eigen vakrichting (zie verder ook de Verklarende woordenlijst). 
Uit de gegevens van het najaar van 2002 blijkt dat er wat betreft werkloosheid onder schoolverlaters van het MBO nauwelijks verschil bestaat tussen Overijssel en Nederland. Verder is het bruto maandloon van schoolverlaters in Overijssel iets lager dan landelijk. Ook de mate waarin schoolverlaters een baan vinden die aansluit bij hun opleidingsniveau en de opleidingsrichting verschilt voor Overijssel niet van Nederland. Overijsselse schoolverlaters werken wel minder in deeltijd, en hebben vaker een vaste baan vergeleken met het gemiddelde van schoolverlaters in Nederland. Uit de Statistische Bijlage (hoofdstuk 3) van dit rapport blijkt overigens wel dat er voor de diverse opleidingssectoren binnen het MBO grotere verschillen tussen Overijssel en Nederland bestaan dan de gemiddeldes over alle opleidingssectoren in tabel 1.4 .

Tabel 1.4

Aansluiting tussen onderwijs en arbeidsmarkt van MBO-schoolverlaters, Overijssel en Nederland, 2002

\begin{tabular}{lcc}
\hline Discrepantie & $\begin{array}{c}\text { Overijssel } \\
\%\end{array}$ & $\begin{array}{c}\text { Nederland } \\
\%\end{array}$ \\
& & \\
Open discrepanties & 3 & 3 \\
werkloos & 3 & 3 \\
intredewerkloosheid minimaal 4 mnd. & 1.300 & 1.350 \\
bruto maandloon* & & \\
Gesloten discrepanties & 13 & 15 \\
flexibel werk & 26 & 31 \\
deeltijdwerk & 33 & 26 \\
onderbenutting & 26 & 23 \\
werk buiten eigen vakrichting & &
\end{tabular}

*) In euro's op basis van een voltijdaanstelling.

Bron: ROA (SIS)

\subsection{De verwachte arbeidsmarktontwikkelingen in Overijssel op hoofdlijnen}

In tabel 1.5 is de verwachte toekomstige arbeidsmarktsituatie voor de provincie Overijssel weergegeven. Uit de tabel blijkt dat in 2004 voor Overijssel een ruimere arbeidsmarkt wordt voorzien ten opzichte van de huidige arbeidsmarktsituatie. Het verwachte vraagtekort in 2004 kan zich voor een deel vertalen in een oplopende werkloosheid, maar ook in dalende lonen waardoor de daling van de vraag naar personeel wordt afgeremd. In 2006 wordt voor zowel Overijssel als Nederland een vraagoverschot voorzien ten opzichte van de situatie in het basisjaar 2001. Het vraagoverschot geeft een indicatie van de verwachte toekomstige kwantitatieve discrepantie op de arbeidsmarkt. Op de verschillende segmenten van de Overijsselse arbeidsmarkt kunnen zich tevens uiteenlopende kwalitatieve discrepanties voordoen, waarbij met name de aansluiting tussen beroep en opleiding centraal staat. Derhalve worden in dit rapport en in de bijgehorende Statistische Bijlage de verwachte knelpunten en perspectieven nader gedifferentieerd naar beroep en opleiding. 
Ook voor het weergegeven vraagoverschot voor de middellange termijn geldt dat dit zich niet uitsluitend vertaalt in een aanpassing van de werkloosheid. Als gevolg van de verwachte 'gap' tussen de vraag- en aanbodontwikkeling kunnen zich verschillende aanpassingsprocessen gaan afspelen. Zo kan een toenemende spanning op de arbeidsmarkt ook leiden tot loonaanpassingen naar boven, waardoor de vraag naar arbeid daalt en het aanbod van arbeid toeneemt. Dit aanpassingsproces kan tevens gedifferentieerd plaatsvinden op de verschillende segmenten van de arbeidsmarkt. Daarnaast kunnen werkgevers hun kwalificatievereisten aanpassen, en kunnen schoolverlaters en werkzoekenden solliciteren in een andere vakrichting dan zij aanvankelijk wensten, of zich laten bij- of omscholen. Andere aanpassingsprocessen zijn bijvoorbeeld ontmoedigings- en aanmoedigingseffecten van degenen die niet actief zoeken naar een baan. Deze zogenaamde 'stille reserve' kan in de loop der tijd meedeinen met de toe- en afname van de vraag naar personeel. Voorts kunnen werkgevers al dan niet besluiten om hun personeel in het buitenland te recruiteren, evenals dat individuen hun emplooi in het buitenland kunnen zoeken. Ook kunnen werkgevers besluiten om hun productieproces anders in te richten, of zelfs de productie gedeeltelijk te stoppen of verplaatsen naar het buitenland. Zowel wat betreft de verdeling van taken behorende bij functies die moeilijk vervulbaar zijn, als wat betreft de arbeidsintensiteit van het productieproces, kunnen werkgevers oplossingen zoeken voor de knelpunten in de personeelsvoorziening.

Tabel 1.5

Verwachte macro arbeidsmarktontwikkeling (als percentage van de werkgelegenheid in het basisjaar) voor de korte en middellange termijn, Overijssel en Nederland

\begin{tabular}{lrrr} 
Kenmerk & $\begin{array}{r}\text { Overijssel } \\
2004 \\
\%\end{array}$ & $\begin{array}{r}\text { Overijssel } \\
2001-2006 \\
\%\end{array}$ & $\begin{array}{r}\text { Nederland } \\
2001-2006 \\
\%\end{array}$ \\
\hline Werkgelegenheidsgroei & $-0,2$ & 2 & 6 \\
Arbeidsmarktuitstroom & 4,8 & 28 & 24 \\
Baanopeningen & 4,6 & 30 & 30 \\
Instroom schoolverlaters & 5,0 & 25 & 25 \\
Vraagoverschot & $-0,4$ & 5 & 5 \\
\hline
\end{tabular}

Bron: CPB/Etil/ROA

Veel van deze aanpassingsprocessen gaan echter gepaard met kosten. Dit geldt zowel voor hogere loonkosten voor werkgevers ten gevolge van een toenemende spanning op de arbeidsmarkt, als voor bijvoorbeeld het aanpassen van de kwalificatievereisten en het daarmee gepaard gaande productiviteitsverlies, de kosten van een reorganisatie en de rekruteringskosten van buitenlands personeel in het buitenland.

Ook voor werkzoekenden spelen aanpassingskosten een rol als de schaarste aan personeel afneemt en het aanbod de vraag overtreft, zoals voor 2004 verwacht wordt. Deze aanpassingskosten hebben niet alleen betrekking op het accepteren van een langere zoekduur om een baan te vinden, maar ook in het accepteren van een baan met slechtere arbeidsvoorwaarden, het accepteren van een baan die minder 
goed aansluit bij de eigen opleidings- en ervaringsachtergrond, en eventuele om- en bijscholingskosten, hogere reiskosten en verhuiskosten.

Uit tabel 1.5 blijkt verder dat de verwachte werkgelegenheidsgroei in Overijssel voor de middellange termijn veel kleiner is dan voor Nederland. Dit hangt voor een deel samen met het gegeven dat de prognoses voor Nederland zijn samengesteld in de tweede helft van 2001, waardoor de omslag op de arbeidsmarkt in 2002 niet is meegenomen. Dit is voor de Overijsselse prognoses wel gebeurd. ${ }^{12}$ De relatief lage werkgelegenheidsgroei voor Overijssel wordt overigens volledig gecompenseerd door de hogere arbeidsmarktuitstroom ten gevolge van bijvoorbeeld tijdelijke uittrede van vrouwen, (vervroegde) pensionering en arbeidsongeschiktheid. Hierdoor komt het percentage baanopeningen op $30 \%$ uit, hetgeen gelijk is aan het landelijke percentage baanopeningen. Een verklaring hiervoor kan niet gelegen zijn in de leeftijdsopbouw van de Overijsselse werkende beroepsbevolking. Eerder is namelijk gebleken dat het aandeel ouderen in de werkende beroepsbevolking 1\%-punt lager ligt dan landelijk. Een mogelijke verklaring kan wel zijn het grote aandeel werkenden in de Agrarische en Pedagogische beroepen in Overijssel. Beide beroepsklassen hebben namelijk, mede vanwege de vergrijzing onder de werkenden in deze beroepen, maar ook door de krimp van de agrarische sector, een hoge uitstroom van werkenden. ${ }^{13}$ Daarentegen heeft Overijssel een zeer laag aandeel werkenden in de Informaticaberoepen. Juist deze beroepsklasse met veel jonge werkenden wordt gekenmerkt door een zeer lage uitstroom.

\subsection{De verwachte arbeidsmarktsituatie naar beroep en opleiding op de korte en middellange termijn}

De arbeidsmarktontwikkelingen op de korte termijn kunnen richtinggevend zijn voor de snel te ondernemen beleidsinspanningen. Hierbij kan onder meer worden gedacht aan de bestrijding van de in hoog tempo oplopende werkloosheid die zich sinds enige tijd voordoet. Deze recente werkloosheidsstijging geeft aanleiding tot de vraag waar op de korte termijn de mogelijkheden voor werkzoekenden liggen. Dit is van belang voor beleidsmakers bij het nemen van arbeidsmarktmaatregelen, voor werkgevers bij het bepalen van hun wervingsstrategie, en voor intermediairs bij het bemiddelen van personeel. Ook voor schoolverlaters die binnenkort de arbeidsmarkt betreden kunnen de geschetste ontwikkelingen informatief zijn bij de keuze van hun sollicitatiestrategie, of bij de eventuele afweging om door te studeren. In het laatste geval dienen bij de studiekeuze vooral de middellangetermijnprognoses in de afweging te worden betrokken. Daarnaast kunnen de middellangetermijnprognoses worden gebruikt door bijvoorbeeld beleidsmakers van het Ministerie van OCenW, onderwijsinstellingen bij het inrichten van de onderwijsinfrastructuur, en door werkgevers bij eventuele strategische beslissingen over hun rekruteringsbeleid.

12. Bij het samenstellen van de regionale werkgelegenheidsprognoses voor Overijssel heeft het Etil de landelijke bedrijfstakprognoses in het Centraal Economisch Plan (CPB, april 2003) meegenomen.

13. Zie blz. 84 in ROA (2001), De arbeidsmarkt naar opleiding en beroep tot 2006, ROA-R2001/8, Maastricht. Overigens leidt de uitstroom van werkenden van de arbeidsmarkt alleen tot vervangingsvraag als deze uitstroom daadwerkelijk vervangen wordt. 
Er dient echter tevens rekening te worden gehouden met de mogelijke grote verschillen in knelpunten in de personeelsvoorziening tussen de verschillende beroepsgroepen binnen één beroepsklasse, en in arbeidsmarktperspectieven tussen de verschillende opleidingstypen binnen één opleidingssector. Voor een verdere differentiatie van de informatie naar de achterliggende vraag- en aanbodontwikkelingen en van de knelpunten en perspectieven naar beroepsgroep en opleidingstype wordt verwezen naar de volgende hoofdstukken in dit rapport en naar de Statistische Bijlage (hoofdstukken 4 en 5) van dit rapport.

Tabel 1.6 laat de knelpunten in de personeelsvoorziening op de korte en middellange termijn zien voor de verschillende beroepsklassen. Voor 2004 zijn de knelpunten in de personeelsvoorziening naar verwachting groot voor de Pedagogische beroepen, de Medische en paramedische beroepen, en de Sociaal-culturele beroepen. In 2006 worden in Overijssel alleen grote knelpunten in de personeelsvoorziening verwacht voor de Pedagogische beroepen en de Sociaal-culturele beroepen. Voor de eerstgenoemde beroepsklasse is dit voornamelijk een gevolg van de relatief lage arbeidsmarktinstroom van schoolverlaters en de relatief hoge vervangingsvraag die daar tegenover staat. Voor de laatstgenoemde beroepsklasse vindt dit zijn oorzaak in de grote werkgelegenheidsgroei die voor de Sociaal-culturele beroepen verwacht wordt (zie verder hoofdstuk 3).

Tabel 1.6

Typering van de toekomstige knelpunten in de personeelsvoorziening voor werkgevers per beroepsklasse (ITKB) op de korte en middellange termijn, Overijssel en Nederland

$\begin{array}{llll}\text { Beroepsklasse } & \text { Overijssel } & \text { Overijssel } & \text { Nederland } \\ & 2004 & & \\ & & & \\ & & & \\ \text { Pedagogische beroepen } & \text { groot } & \text { groot } & \text { zeer groot } \\ \text { Culturele beroepen } & \text { enige } & \text { enige } & \text { groot } \\ \text { Agrarische beroepen } & \text { enige } & \text { enige } & \text { vrijwel geen } \\ \text { Technische en industrieberoepen } & \text { enige } & \text { vrijwel geen } & \text { groot } \\ \text { Transportberoepen } & \text { enige } & \text { vrijwel geen } & \text { vrijwel geen } \\ \text { Medische en paramedische beroepen } & \text { groot } & \text { enige } & \text { zeer groot } \\ \text { Economisch-administratieve beroepen } & \text { enige } & \text { enige } & \text { groot } \\ \text { enige } & \text { groot } \\ \text { Informaticaberoepen } & \text { enige } & \text { groot } & \text { groot } \\ \text { Sociaal-culturele beroepen } & \text { groot } & \text { groot } \\ \text { Verzorgende en dienstverlenende beroepen } & \text { enige } & \text { vrijwel geen } & \text { vrijwel geen } \\ \text { Openbare orde- en veiligheidsberoepen } & \text { enige } & \text { enige } & \text { groot }\end{array}$

\footnotetext{
*) De landelijke prognoses dateren van november 2001 en worden in het najaar van 2003 geactualiseerd.
}

Bron: ROA

Over het algemeen zijn de verwachte knelpunten in de personeelsvoorziening voor Overijssel kleiner dan voor Nederland. Zoals in de vorige paragraaf reeds is opgemerkt, dient er rekening mee gehouden te worden dat in de Nederlandse prognoses de recente conjunctuuromslag niet kon worden meegenomen. Met name voor de verschillen met betrekking tot de Technische en industrieberoepen, de Economisch-administratieve beroepen en de Informaticaberoepen kan dit van belang zijn. 
Tabel 1.7 geeft de toekomstige arbeidsmarktperspectieven van schoolverlaters in Overijssel weer voor de korte en de middellange termijn. Voor ongeschoolden met alleen Basisonderwijs en in iets mindere mate ook voor de verschillende VMBOopleidingsrichtingen lijkt het perspectief gunstig te zijn, maar daarbij geldt een belangrijke kanttekening. Ongeschoolden en lager opgeleiden komen veelal in zogenaamde 'dead-end jobs' terecht onder relatief slechte arbeidsvoorwaarden en zonder veel carrièreperspectief. De doorstroom van ongeschoolde en laagopgeleide werkenden door middel van het volgen van postinitiële scholing naar een hoger opleidingsniveau is heel gebruikelijk. ${ }^{14}$ Hierdoor ontstaat er vervangingsvraag naar nieuw (jong) personeel zonder veel vooropleiding. Zonder adequate omscholing dreigt er op termijn uittrede van de arbeidsmarkt en non-participatie. Hieruit blijkt dat het goede perspectief dat voor Basisonderwijs en een aantal opleidingssectoren van het $V M B O$ wordt aangegeven, gerelativeerd moet worden.

De arbeidsmarktperspectieven voor schoolverlaters van $M B O$ Economie in Overijssel zijn zowel op de korte als de middellange termijn goed. Voor MBO Techniek geldt dit alleen voor de middellange termijn, omdat er in 2004 een relatief grote arbeidsmarktinstroom van schoolverlaters met een diploma van een middelbare technische beroepsopleiding wordt verwacht (zie verder hoofdstuk 2). Hetzelfde geldt voor de arbeidsmarktinstroom van schoolverlaters met een diploma in opleidingssector $M B O$ Landbouw en natuurlijke omgeving. MBO'ers die in 2004 met een dergelijke opleidingsachtergrond op de arbeidsmarkt instromen hebben een matig perspectief. Op de middellange termijn verbetert het arbeidsmarktperspectief van deze schoolverlaters weer.

Tabel 1.7

Typering van de toekomstige arbeidsmarktperspectieven voor schoolverlaters per opleidingssector (ITA) op de korte en middellange termijn, Overijssel en Nederland

\begin{tabular}{llll} 
Beroepsklasse & $\begin{array}{l}\text { Overijssel } \\
2004\end{array}$ & $\begin{array}{l}\text { Overijssel } \\
2001-2006\end{array}$ & $\begin{array}{l}\text { Nederland } \\
2001-2006^{*}\end{array}$ \\
\hline & & & \\
Basisonderwijs & goed & goed & redelijk \\
VMBO Theorie & goed & goed & matig \\
VMBO Landbouw en natuurlijke omgeving & redelijk & redelijk & matig \\
VMBO Techniek & goed & goed & matig \\
VMBO Economie & goed & goed & slecht \\
VMBO Verzorging & redelijk & redelijk & matig \\
HAVO/VWO & redelijk & redelijk & matig \\
MBO Landbouw en natuurlijke omgeving & matig & redelijk & goed \\
MBO Techniek & redelijk & goed & goed \\
MBO Economie & goed & goed & goed \\
MBO Dienstverlening en gezondheidszorg & redelijk & redelijk & goed
\end{tabular}

*) Landelijke prognoses dateren van november 2001 en worden in het najaar van 2003 geactualiseerd.

Bron: ROA

14. Zie ook hoofdstuk 5 in ROA (2001), De arbeidsmarkt naar opleiding en beroep tot 2006, ROA-R-2001/8, Maastricht. 



\section{De instroom van schoolverlaters op de Overijsselse arbeidsmarkt}

Bijna 12.000 VMBO'ers hebben hun opleiding in 2001 succesvol afgerond. Hiermee is het aantal gediplomeerden ongeveer 200 hoger dan in het jaar 2000. In 2001 hebben 11.900 MBO'ers hun diploma gehaald. Dit is ongeveer 175 meer dan in het jaar ervoor. De meeste Overijsselse MBO'ers hebben een opleiding in de sector $M B O$ Economie gevolgd. In deze sector is er echter wel sprake van een lichte afname van het aantal gediplomeerden. De sterkst groeiende sector ten opzichte van het jaar 2000 is MBO Dienstverlening en gezondheidszorg. Ongeveer 37\% van de gediplomeerden heeft een opleiding in de beroepsbegeleidende leerweg (BBL) gevolgd. Het aandeel BBL'ers is het grootst in de sector MBO Techniek, waar ruim $66 \%$ van de gediplomeerden heeft gekozen voor een beroepsbegeleidend traject. In de sector MBO Economie daarentegen heeft ongeveer $82 \%$ van de gediplomeerden een opleiding in de beroepsopleidende leerweg (BOL) gevolgd.

Het aantal VMBO-leerlingen is in 2001 hoger dan in 2000. Het overgrote deel (meer dan 72.000 leerlingen) volgt de theoretische leerweg of zit in de eerste twee jaar van de opleiding (de zogenaamde basisvorming). Het aantal leerlingen in VMBO Theorie is gedaald ten opzichte van 2001. De stijging van het aantal leerlingen in het VMBO is te danken aan een stijging binnen de overige VMBO sectoren. De grootste stijging kent VMBO Landbouw en natuurlijke omgeving. Het aantal leerlingen in deze sector is van 1.200 naar 2.875 gestegen. Het aantal leerlingen in het MBO is ook licht gestegen. De grootste procentuele stijging vindt plaats binnen MBO Landbouw en natuurlijke omgeving. Het aantal leerlingen in de overige sectoren verschuift nauwelijks. De sector MBO Economie is met bijna 13.000 leerlingen het grootst. In populariteit groeiende opleidingen zijn $M B O I C T, M B O$ verpleging, en $M B O$ administratie en logistiek. Ongeveer $37 \%$ van de Overijsselse MBO'ers volgt een opleiding volgens de meer praktisch georiënteerde beroepsbegeleidende leerweg.

De verwachte arbeidsmarktinstroom van schoolverlaters als percentage van de werkgelegenheid schommelt voor de meeste lagere en middelbare opleidingssectoren rond de 5\%. In 2004 zijn er naar verwachting vier belangrijke uitschieters naar boven: VMBO Landbouw en natuurlijke omgeving, HAVO/VWO, MBO Landbouw en natuurlijke omgeving en MBO Techniek. Voor de middellange termijn (tot 2006) laat behalve VMBO Landbouw en natuurlijke omgeving, HAVO/VWO, $M B O$ Landbouw en natuurlijke omgeving en VMBO Economie een relatief grote arbeidsmarktinstroom zien.

De uitwijkmogelijkheden geven een indicatie van de mogelijkheden die schoolverlaters hebben - mochten de kansen op de arbeidsmarkt in het eigen beroependomein gering zijn - om uit te wijken naar andere beroepen. Zowel in Nederland als Overijssel zijn er wat betreft de uitwijkmogelijkheden aanzienlijke verschillen tussen de onderwijssectoren binnen het VMBO en MBO. Ten opzichte van de rest van Nederland zijn de uitwijkmogelijkheden in Overijssel veel groter. Dit kan duiden op een gevarieerdere beroepenstructuur in Overijssel. 


\subsection{Inleiding}

In dit hoofdstuk staat het Overijssels beroepsonderwijs centraal. De nadruk ligt hierbij op het in kaart brengen van het huidige en toekomstige aanbod van lager en middelbaar opgeleiden op de Overijsselse arbeidsmarkt. De opzet van dit hoofdstuk is als volgt. In paragraaf 2.2 wordt aandacht geschonken aan het aantal leerlingen dat recent een opleiding in het beroepsonderwijs succesvol heeft afgerond. Dit aantal gediplomeerden geeft inzicht in het huidige aanbod van VMBO'ers en MBO'ers in Overijssel. In paragraaf 2.3 wordt aandacht geschonken aan het aantal leerlingen dat momenteel in Overijssel een opleiding op VMBO- of MBO-niveau volgt. Inzicht in dit aantal leerlingen geeft een eerste indicatie van het toekomstig aanbod van schoolverlaters voor vervolgopleidingen of voor de arbeidsmarkt in Overijssel. Paragraaf 2.4 gaat in op de verwachte arbeidsmarktinstroom in Overijssel op de korte en middellange termijn. Ten slotte wordt in paragraaf 2.5 aandacht geschonken aan de uitwijkmogelijkheden van MBO-schoolverlaters. Deze uitwijkmogelijkheden geven een indicatie van de mogelijkheden die schoolverlaters hebben om uit te wijken naar andere beroepen. Dit kan van belang zijn als bijvoorbeeld de kansen op de arbeidsmarkt in het eigen beroependomein tegenvallen.

\subsection{Het aantal gediplomeerden in Overijssel}

Het aantal gediplomeerden geeft een indicatie van het huidige aanbod van schoolverlaters voor vervolgopleidingen en voor de Overijsselse arbeidsmarkt. In tabel 2.1 wordt een overzicht gegeven van het aantal gediplomeerden in Overijssel naar onderwijssector. ${ }^{15}$

Uit de tabel blijkt dat bijna 12.000 VMBO'ers hun opleiding in 2001 succesvol hebben afgerond. Hiermee is het aantal gediplomeerden ongeveer 200 hoger dan in het jaar 2000 (zie echter de voetnoot bij de tabel). Bijna de helft van de VMBO'ers heeft een opleiding volgens de theoretische leerweg gevolgd. In feite betreft het hier MAVOschoolverlaters die voor de herstructurering van het VBO en de MAVO aan hun opleiding zijn begonnen. VMBO Theorie kan worden beschouwd als de opvolger van de MAVO-opleiding. Op een lager aggregatieniveau blijkt dat er, behalve bij VMBO Landbouw en natuurlijke omgeving, geen grote stijgingen of dalingen in het aantal gediplomeerden zijn.

Uit de tabel blijkt ook dat 11.900 MBO'ers hun diploma hebben gehaald. Dit is zo'n 175 meer dan in het jaar 2000. De meeste Overijsselse MBO'ers hebben een opleiding in de sector MBO Economie gevolgd. In deze sector is er sprake van een lichte afname van het aantal gediplomeerden. De sterkst groeiende sector ten opzichte van 2000 is MBO Dienstverlening en gezondheidszorg. Binnen deze sector stijgt vooral het aantal gediplomeerden met de opleiding $M B O$ verpleging. Binnen de sector MBO Economie valt vooral de stijging in MBO ICT op.

15. De gediplomeerden en leerlingen van $V M B O$ beveiliging en $M B O$ openbare orde en veiligheid vallen in dit hoofdstuk onder de opleidingssector VMBO Economie respectievelijk MBO Economie. 
Tabel 2.1

Aantal gediplomeerden van het VMBO en het MBO in Overijssel naar opleiding, kalenderjaar 2000 en 2001

\begin{tabular}{|c|c|c|}
\hline \multirow[b]{2}{*}{ Opleidingssector } & \multicolumn{2}{|c|}{ Aantal gediplomeerden } \\
\hline & 2000 & 2001 \\
\hline VMBO Theorie & 5.200 & 5.000 \\
\hline VMBO Landbouw en natuurlijke omgeving & $175^{\star}$ & 500 \\
\hline VMBO Techniek & 2.625 & 2.700 \\
\hline VMBO Verzorging & 1.875 & 1.900 \\
\hline VMBO Economie & 1.550 & 1.525 \\
\hline VMBO Totaal & 11.425 & 11.625 \\
\hline HAVO/VWO & 7.650 & 6.350 \\
\hline MBO Landbouw en natuurlijke omgeving & $950^{*}$ & 1.000 \\
\hline MBO Techniek & 3.650 & 3.500 \\
\hline MBO Economie & 4.375 & 4.275 \\
\hline MBO Dienstverlening en gezondheidszorg & 2.750 & 3.125 \\
\hline MBO Totaal & 11.725 & 11.900 \\
\hline
\end{tabular}

* De gegevens van de gediplomeerden in de Landbouwopleidingen in 2000 hebben alleen betrekking op de gediplomeerden die niet in het onderwijs doorstromen.

Bron: CFI/ROA

In tabel 2.2 wordt de succesvolle uitstroom uit de MBO-opleidingen uitgesplitst naar leerweg. Ongeveer $37 \%$ van de gediplomeerden heeft een BBL-opleiding gevolgd. Het aandeel BBL'ers is het grootst in de sector MBO Techniek, waar ruim $66 \%$ van de gediplomeerden heeft gekozen voor een beroepsbegeleidend traject. In de sector MBO Economie daarentegen heeft ongeveer $82 \%$ van de gediplomeerden een BOLopleiding gevolgd.

Tabel 2.2

Aantal gediplomeerden van het MBO in Overijssel naar leerweg en opleidingssector, kalenderjaar 2001

\begin{tabular}{|c|c|c|c|}
\hline \multirow[b]{2}{*}{ Opleidingssector } & \multicolumn{3}{|c|}{ Aantal gediplomeerden } \\
\hline & BOL & BBL & Totaal \\
\hline MBO Landbouw en natuurlijke omgeving & 575 & 425 & 1.000 \\
\hline MBO Techniek & 1.200 & 2.300 & 3.500 \\
\hline MBO Economie & 3.500 & 775 & 4.275 \\
\hline MBO Dienstverlening en gezondheidszorg & 2.200 & 925 & 3.125 \\
\hline Totaal & 7.475 & 4.425 & 11.900 \\
\hline
\end{tabular}

Bron: CFI/ROA 


\subsection{Het aantal leerlingen in Overijssel}

Met behulp van het aantal leerlingen kan een eerste indicatie worden gegeven van het toekomstig aanbod voor vervolgopleidingen en voor de arbeidsmarkt in Overijssel. Tabel 2.3 laat zien dat het aantal VMBO-leerlingen in 2001 hoger is dan in 2000. Het overgrote deel van de leerlingen (meer dan 72.000 leerlingen) volgt de theoretische leerweg of zit in de eerste twee jaar van de opleiding (de zogenaamde basisvorming). Het aantal leerlingen in VMBO Theorie is gedaald ten opzichte van 2001. De stijging van het aantal leerlingen in het VMBO is te danken aan een stijging binnen de overige VMBO sectoren. De grootste stijging kent VMBO Landbouw en natuurlijke omgeving. Het aantal leerlingen in deze sector is gestegen van 1.200 naar 2.875 .

Uit de tabel blijkt ook dat het aantal leerlingen in het MBO licht gestegen is. De grootste procentuele stijging vindt plaats binnen MBO Landbouw en natuurlijke omgeving. Het aantal leerlingen in de overige sectoren verschuift nauwelijks. De sector MBO Economie is met bijna 13.000 leerlingen het grootst.

Tabel 2.3

Aantal (bekostigde) leerlingen in het VMBO en het MBO in Overijssel naar opleidingssector, kalenderjaar 2000 en 2001

\begin{tabular}{lcc}
\hline & \multicolumn{2}{c}{ Aantal leerlingen } \\
Opleidingssector & 2000 & 2001 \\
\hline & & \\
VMBO Theorie en basisvorming & 75.125 & 72.325 \\
VMBO Landbouw en natuurlijke omgeving & 1.200 & 2.875 \\
VMBO Techniek & 7.550 & 9.325 \\
VMBO Economie & 6.775 & 9.950 \\
VMBO Verzorging & 4.825 & 5.600 \\
VMBO Totaal & & 100.075 \\
HAVO/VWO & 95.475 & 41.600 \\
MBO Landbouw en natuurlijke omgeving & 41.275 & 3.280 \\
MBO Techniek & & 11.750 \\
MBO Economie & 2.375 & 12.800 \\
MBO Dienstverlening en gezondheidszorg & 12.150 & 10.250 \\
MBO Totaal & 12.125 & 38.100 \\
& 10.300 & \\
\hline BrOn: CFl/ROA & 36.950 & \\
\hline
\end{tabular}

Bron: CFI/ROA

Ook binnen de sector MBO Techniek zijn er weinig grote verschuivingen. $M B O$ werktuigbouw en mechanische techniek verliest echter ruim $10 \%$ van haar leerlingen (140 personen) en MBO bouw heeft 3\% leerlingen minder (100 leerlingen). De grootste relatieve stijging doet zich voor bij $M B O$ vliegtuigtechniek: van 20 naar 70 leerlingen. Binnen de sector $M B O$ Dienstverlening en gezondheidszorg nemen de opleidingen $M B O$ verpleging (10\%) en $M B O$ verzorging (5\%) in populariteit toe. Het aantal leerlingen dat de opleiding $M B O$ sociaal-pedagogisch en welzijn volgt is daarentegen met 170 gedaald (5\%). Het aantal leerlingen in MBO horeca daalde in 
2001 met 12,5\% (190 leerlingen minder). Binnen de sector MBO Economie stijgt de opleiding MBO ICT relatief het snelst in populariteit. In één jaar heeft deze opleiding er 400 leerlingen bij gekregen (23\%). Ook MBO administratie en logistiek (440 nieuwe leerlingen) stijgt met ongeveer $14 \%$. MBO geld, bank en belastingen daalt van 260 naar 150 leerlingen.

In tabel 2.4 wordt voor het MBO een uitsplitsing gemaakt naar leerweg. Ongeveer $37 \%$ van de Overijsselse MBO'ers volgt een opleiding volgens de meer praktisch georiënteerde beroepsbegeleidende leerweg. Dit percentage is hetzelfde als het percentage BBL-gediplomeerden, zoals uit tabel 2.2 is af te leiden.

Wanneer de aandelen BBL-leerlingen per sector vergeleken worden met de aandelen BBL-gediplomeerden per sector (tabel 2.2) is opvallend dat in de sector MBO Landbouw en natuurlijke omgeving $31 \%$ van de leerlingen een BBL-opleiding volgt terwijl het aandeel BBL'ers onder de gediplomeerden met $43 \%$ duidelijk hoger is. Dit kan erop wijzen dat in deze sector de uitval uit de BOL-opleidingen relatief groot is. Wellicht is het raadzaam leerlingen in deze sector meer op de mogelijkheden in het BBL te wijzen omdat gezien het meer praktische en daarmee laagdrempelige karakter het een belangrijke rol kan vervullen in het streven iedereen een startkwalificatie te laten behalen. In de overige MBO sectoren is het aantal leerlingen in de verschillende leerwegen meer in balans met het aantal gediplomeerden.

Tabel 2.4

Aantal (bekostigde) leerlingen in het MBO in Overijssel naar leerweg en opleidingssector, kalenderjaar 2001

\begin{tabular}{lrrr}
\hline & & Aantal leerlingen \\
Opleidingssector & BOL & BBL & Totaal \\
\hline MBO Landbouw en natuurlijke omgeving & 2.275 & 1.025 & 3.300 \\
MBO Techniek & 4.625 & 7.125 & 11.750 \\
MBO Economie & 10.325 & 2.475 & 12.800 \\
MBO Dienstverlening en gezondheidszorg & 6.850 & 3.400 & 10.250 \\
& & & 38.100 \\
Totaal & 24.075 & 14.025 & \\
\hline Bron: CFI/ROA & & &
\end{tabular}

Zoals bekend, zijn er in het MBO grote traditionele verschillen in de opleidingskeuze van mannen en vrouwen. Uit tabel 2.5 blijkt dat het grootste verschil zich voordoet bij MBO Techniek en MBO Dienstverlening en gezondheidszorg. Slechts $7 \%$ van de leerlingen van de technische opleidingen is vrouw. Bij opleidingen als $M B O$ installatietechniek, MBO vliegtuigtechniek en $M B O$ elektrotechniek is het aantal vrouwen zelfs te verwaarlozen (1\% of minder). Opleidingen als $M B O$ laboratorium (46\%) en MBO grafische techniek (28\%) zijn onder vrouwen daarentegen relatief populair. 
In de sector MBO Dienstverlening en gezondheidszorg zijn vrouwen met $82 \%$ ruim in de meerderheid. In opleidingen als $M B O$ dokters-, tandarts- en dierenartsassistent, MBO apothekersassistent en MBO uiterlijke verzorging is meer dan $95 \%$ van de leerlingen vrouw. In de opleiding MBO horeca zijn vrouwen echter met $39 \%$ in de minderheid.

In de sector $M B O$ Landbouw en natuurlijke omgeving zijn de aantallen mannen en vrouwen veel meer in evenwicht. Datzelfde geldt voor de sector MBO Economie. Binnen deze sector zijn de verschillen echter groot. Zo zijn bijna alle leerlingen binnen $M B O$ secretariaat en meer dan $80 \%$ van de leerlingen van de opleiding $M B O$ toerisme en recreatie vrouw, terwijl er bijna geen vrouwen MBO ICT of MBO facilitaire dienstverlening volgen.

In het VMBO zijn in de sector VMBO Verzorging de vrouwen in de meerderheid $(75 \%)$, terwijl in de sectoren VMBO Landbouw en natuurlijke omgeving en VMBO Economie mannen en vrouwen elkaar min of meer in evenwicht houden. Dit komt overeen met het beeld bij het MBO. In de sector VMBO Techniek is het beeld echter afwijkend. Maar liefst $44 \%$ van de technisch opgeleiden in het VMBO is vrouw.

Tabel 2.5

Aantal (bekostigde) leerlingen in het VMBO en $\mathrm{MBO}$ in Overijssel naar geslacht en opleidingssector, kalenderjaar 2001

\begin{tabular}{|c|c|c|c|}
\hline \multirow[b]{2}{*}{ Opleidingssector } & \multicolumn{2}{|c|}{ Aantal leerlingen } & \multirow[b]{2}{*}{ Totaal } \\
\hline & Mannen & Vrouwen & \\
\hline VMBO Theorie en basisvorming & 38.575 & 33.750 & 72.325 \\
\hline VMBO Landbouw en natuurlijke omgeving & 1.575 & 1.300 & 2.875 \\
\hline VMBO Techniek & 5.225 & 4.100 & 9.325 \\
\hline VMBO Economie & 4.575 & 5.375 & 9.950 \\
\hline VMBO Verzorging & 1.400 & 4.200 & 5.600 \\
\hline VMBO Totaal & 51.350 & 48.725 & 100.075 \\
\hline HAVO/VWO & 18.425 & 23.175 & 41.600 \\
\hline MBO Landbouw en natuurlijke omgeving & 2.050 & 1.250 & 3.300 \\
\hline MBO Techniek & 10.950 & 800 & 11.750 \\
\hline MBO Economie & 6.575 & 6.225 & 12.800 \\
\hline MBO Dienstverlening en gezondheidszorg & 1.875 & 8.375 & 10.250 \\
\hline MBO Totaal & 21.450 & 16.650 & 38.100 \\
\hline
\end{tabular}

Bron: CFI/ROA

\subsection{Aanbod van schoolverlaters}

Het aanbod op de arbeidsmarkt wordt, naast de kortdurig werklozen, met name bepaald door de verwachte arbeidsmarktinstroom van schoolverlaters. ${ }^{16}$ In deze

16. Met de arbeidsmarktinstroom van herintreders is reeds, impliciet, rekening gehouden bij het bepalen van de vervangingsvraag. 
paragraaf wordt een overzicht gegeven van het aanbod van schoolverlaters op de arbeidsmarkt voor de korte en middellange termijn. Ook hier zal slechts een overzicht van de lagere en middelbare opleidingssectoren worden gegeven. Omdat afgestudeerden van het hoger onderwijs een grote geografische mobiliteit laten zien, worden voor de opleidingen van het $\mathrm{HBO}$ en WO geen regionale prognoses van de arbeidsmarktinstroom gepresenteerd. ${ }^{17}$

De verwachte arbeidsmarktinstroom van schoolverlaters schommelt voor de meeste lagere en middelbare opleidingssectoren op de korte termijn rond de $5 \%$, met vier belangrijke uitschieters naar boven: VMBO Landbouw en natuurlijke omgeving, HAVONWO, MBO Landbouw en natuurlijke omgeving en MBO Techniek. Voor de middellange termijn is de verwachte arbeidsmarktinstroom iets lager. Behalve $V M B O$ Landbouw en natuurlijke omgeving, HAVONWO en MBO Landbouw en natuurlijke omgeving, laat ook VMBO Economie een relatief grote arbeidsmarktinstroom zien. De arbeidsmarktinstroom vanuit de verschillende VMBO-opleidingen en het HAVO/VWO is voor een belangrijk deel afkomstig van werkenden die postinitieel een dergelijke opleiding hebben gevolgd.

Tabel 2.6

Verwachte arbeidsmarktinstroom van schoolverlaters naar opleidingssector op korte termijn en middellange termijn als percentage van de werkgelegenheid in het basisjaar, Overijssel

\begin{tabular}{lrr} 
Opleidingssector & $\begin{array}{r}\text { Overijssel } \\
2003-2004 \\
\%\end{array}$ & $\begin{array}{r}\text { Overijssel } \\
2001-2006 \\
\text { Jaarlijks \% }\end{array}$ \\
\hline Basisonderwijs & 4,9 & 4,9 \\
VMBO Theorie & 4,6 & 4,0 \\
VMBO Landbouw en natuurlijke omgeving & & 6,3 \\
VMBO Techniek & 7,3 & 5,0 \\
VMBO Economie & 4,3 & 5,9 \\
VMBO Verzorging & 5,7 & 5,3 \\
HAVO/VWO & 6,7 & 7,6 \\
& & 6,6 \\
MBO Landbouw en natuurlijke omgeving & 7,2 & 4,7 \\
MBO Techniek & 10,6 & 4,3 \\
MBO Economie & 7,5 & 5,3 \\
MBO Dienstverlening en gezondheidszorg & 4,7 & 4,5 \\
Totaal (incl. HBO en WO) & 4,7 & \\
& & \\
\hline BO ROA
\end{tabular}

Bron: ROA

De onderliggende opleidingstypen laten een gevarieerd beeld zien. In het onderstaande kader worden de opleidingstypen weergegeven waarvoor op de korte en de

17. Voor de landelijke instroomprognoses voor de periode 2001-2006 van de HBO- en WOopleidingen wordt de geïnteresseerde lezer verwezen naar ROA (2001), De arbeidsmarkt naar opleiding en beroep tot 2006, ROA-R-2001/8, Maastricht. 
middellange termijn een hoge of lage arbeidsmarktinstroom van schoolverlaters verwacht wordt.

\section{KORTE TERMIJN}

Lagere en middelbare opleidingstypen met een relatief hoge arbeidsmarktinstroom van schoolverlaters in Overijssel:

- VMBO administratie

- VMBO handel en textiel

- MBO grafische techniek

- MBO motorvoertuigentechniek en tweewielers

- MBO horeca

- MBO bouw

- MBO sociaal-pedagogisch en welzijn

- MBO uiterlijke verzorging

- $\mathrm{MBO}$ facilitaire dienstverlening

Lagere en middelbare opleidingstypen met een relatief lage arbeidsmarktinstroom van schoolverlaters in Overijssel:

- VMBO vervoer

- MBO geld, bank en belastingen

- MBO openbare orde en veiligheid

\section{MIDDELLANGE TERMIJN}

Lagere en middelbare opleidingstypen met een relatief hoge arbeidsmarktinstroom van schoolverlaters in Overijssel:

- VMBO administratie, handel en textiel

- VMBO elektrotechniek

- MBO bouw

- MBO sociaal-pedagogisch en welzijn

- $\mathrm{MBO}$ uiterlijke verzorging

- $\mathrm{MBO}$ facilitaire dienstverlening

Lagere en middelbare opleidingstypen met een relatief lage arbeidsmarktinstroom van schoolverlaters in Overijssel:

- VMBO fijnmechanische techniek

- VMBO vervoer

- MBO geld, bank en belastingen

- MBO procestechniek

- $\mathrm{MBO}$ openbare orde en veiligheid

De arbeidsmarktinstroom op de middellange termijn levert voor Overijssel en Nederland een vergelijkbaar beeld op. Op MBO-niveau ligt de arbeidsmarktinstroom voor de middellange termijn over het algemeen wat hoger in Overijssel dan in Nederland. Dit geldt met name voor MBO Landbouw en natuurlijke omgeving. Voor de lagere opleidingssectoren is de instroom op de Overijsselse arbeidsmarkt voor de middellange termijn relatief hoog voor VMBO Techniek. Daarentegen zullen er in Overijssel minder schoolverlaters met een HAVO/VWO-opleiding op de arbeidsmarkt instromen. 
Figuur 2.1

Verwachte arbeidsmarktinstroom van schoolverlaters naar opleidingssector als percentage van de werkgelegenheid in het basisjaar, 2001-2006, Overijssel en Nederland

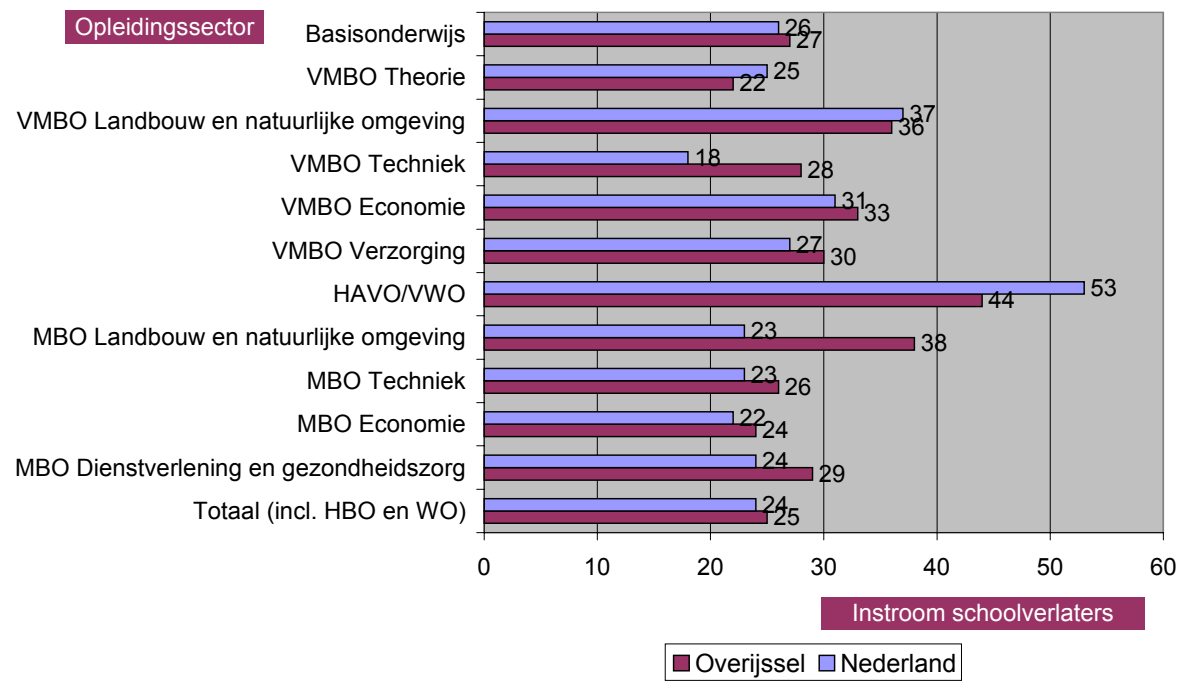

Bron: ROA

\subsection{Uitwijkmogelijkheden naar beroepsgroep voor gediplomeerde school- verlaters}

De arbeidsmarktpositie van schoolverlaters wordt voor een belangrijk deel bepaald door de ontwikkelingen aan de vraag- en aanbodzijde van de Overijsselse arbeidsmarkt. Wanneer de vraag naar schoolverlaters stijgt of het aanbod afneemt, wordt de arbeidsmarktpositie gemiddeld genomen beter. De werkloosheid zal dan dalen, de lonen zullen stijgen, de aansluiting tussen opleiding en beroep zal beter worden en schoolverlaters zullen minder vaak een tijdelijke aanstelling hoeven te aanvaarden. Wanneer daarentegen de vraag daalt of het aanbod toeneemt, zal de werkloosheid stijgen, zullen de lonen stagneren, zullen meer schoolverlaters beneden hun niveau of buiten hun eigen richting emplooi moeten vinden en zullen er meer schoolverlaters met een tijdelijk contract werkzaam zijn.

Het zijn echter niet alleen de vraag-aanbodverhoudingen die de arbeidsmarktpositie van een opleiding bepalen. Ook structurele factoren spelen een rol. Deze structurele kenmerken van de arbeidsmarktpositie geven een indicatie van de arbeidsmarktrisico's die de keuze voor een bepaalde opleiding met zich meebrengt. Zo komt het arbeidsmarktrisico van een bepaalde opleidingskeuze tot uiting in de mate waarin schoolverlaters afhankelijk zijn van de werkgelegenheidsontwikkeling in slechts een beperkt aantal beroepen of bedrijfssectoren. Dit risico is vooral groot bij zogenaamde 'smalle' opleidingen, dat wil zeggen: opleidingen die specifiek gericht zijn op functies in een bepaalde vakdeelmarkt. Degenen die daarentegen een opleiding hebben gevolgd waarmee men in diverse beroepen en bedrijfssectoren emplooi kan vinden, 
kunnen als de arbeidsmarktsituatie in een bepaalde beroepsgroep minder gunstig is, betrekkelijk gemakkelijk uitwijken naar beroepen waarvoor de werkgelegenheidsontwikkeling gunstiger is. Bovendien zijn degenen die voor deze zogenaamde 'brede' opleidingen hebben gekozen ook meer flexibel op de arbeidsmarkt wanneer men tijdens de studie- of arbeidsloopbaan meer inzicht krijgt in de persoonlijke capaciteiten en voorkeuren die men heeft, waardoor de specifieke beroepskenmerken die aanvankelijk aanlokkelijk leken, hun aantrekkingskracht kunnen verliezen.

Het vinden van werk in een brede waaier van beroepen en bedrijfssectoren als gevolg van de grote uitwijkmogelijkheden kan echter ook duiden op een zwakke arbeidsmarktpositie. De keerzijde van grote uitwijkmogelijkheden is derhalve dat schoolverlaters met een brede opleiding een relatief zwakke positie op hun eigen beroependomein kunnen innemen. Zo kunnen VMBO'ers terechtkomen in banen waarvoor nauwelijks of geen scholing is vereist, de zogenaamde 'secundaire arbeidsmarkt'.

Tabel 2.7

Uitwijkmogelijkheden naar verschillende beroepsgroepen van werkenden per opleidingssector (in procenten) in Overijssel en Nederland, gemiddelde 2000-2001

\begin{tabular}{|c|c|c|c|c|c|c|}
\hline \multirow[b]{2}{*}{ Opleidingssector } & \multicolumn{3}{|c|}{$\begin{array}{l}\text { Overijssel } \\
\text { Typering uitwijkmogelijkheden }\end{array}$} & \multicolumn{3}{|c|}{$\begin{array}{l}\text { Nederland } \\
\text { Typering uitwijkmogelijkheden }\end{array}$} \\
\hline & $\begin{array}{l}\text { (Erg) } \\
\text { laag }\end{array}$ & Gemiddeld & $\begin{array}{l}\text { (Erg) } \\
\text { hoog }\end{array}$ & $\begin{array}{r}\text { (Erg) } \\
\text { laag }\end{array}$ & Gemiddeld & $\begin{array}{l}(E r g) \\
\text { hoog }\end{array}$ \\
\hline VMBO Theorie & 0 & 0 & 100 & 0 & 0 & 100 \\
\hline $\begin{array}{l}\text { VMBO Landbouw } \\
\text { en natuurlijke omgeving }\end{array}$ & 0 & 0 & 100 & 0 & 100 & 0 \\
\hline VMBO Techniek & 5 & 31 & 63 & 37 & 33 & 31 \\
\hline VMBO Economie & 0 & 29 & 71 & 0 & 0 & 100 \\
\hline VMBO Verzorging & 0 & 0 & 100 & 0 & 0 & 100 \\
\hline HAVO/VWO & 0 & 0 & 100 & 0 & 0 & 100 \\
\hline $\begin{array}{l}\text { MBO Landbouw } \\
\text { en natuurlijke omgeving }\end{array}$ & 0 & 100 & 0 & 25 & 75 & 0 \\
\hline MBO Techniek & 5 & 62 & 33 & 34 & 59 & 7 \\
\hline MBO Economie & 4 & 53 & 43 & 17 & 43 & 40 \\
\hline $\begin{array}{l}\text { MBO Dienstverlening } \\
\text { en gezondheidszorg }\end{array}$ & 6 & 66 & 27 & 38 & 62 & 0 \\
\hline
\end{tabular}

Bron: CBS(EBB)/ROA

Tabel 2.7 laat zien hoe groot de uitwijkmogelijkheden naar de verschillende beroepen zijn voor de VMBO'ers en MBO'ers die hun opleiding in 2001 succesvol hebben afgerond. De resultaten zijn apart voor Overijssel en Nederland berekend. Uit de tabel blijkt zoals verwacht dat VMBO'ers gemiddeld grotere uitwijkmogelijkheden hebben dan schoolverlaters van het MBO. Over het algemeen zal er immers een specifiekere vraag zijn naar MBO-schoolverlaters, terwijl VMBO'ers in meerdere beroepsgroepen ongeschoold werk doen. 
Uit tabel 2.7 blijkt verder dat er aanzienlijke verschillen zijn wat betreft de uitwijkmogelijkheden tussen de onderwijssectoren binnen zowel het VMBO als het MBO. ${ }^{18}$ Schoolverlaters met een opleiding $V M B O$ Landbouw en natuurlijke omgeving en VMBO Techniek hebben grotere uitwijkmogelijkheden in Overijssel dan in Nederland. Bij VMBO Techniek komt dit doordat er in Overijssel grotere uitwijkmogelijkheden zijn voor VMBO mechanische techniek, VMBO voertuigentechniek en VMBO bouwtechniek. Er zijn in Overijssel kleinere uitwijkmogelijkheden voor VMBO brood en banket. Schoolverlaters met een opleiding VMBO Economie hebben daarentegen in Nederland grotere uitwijkmogelijkheden. Dit komt doordat VMBO consumptief en levensmiddelen in Nederland hoge en in Overijssel gemiddelde uitwijkmogelijkheden heeft.

In het MBO hebben alle opleidingssectoren grotere uitwijkmogelijkheden in Overijssel. Bij MBO Landbouw en natuurlijke omgeving heeft het opleidingstype MBO milieu en groene ruimte in Nederland lage en in Overijssel gemiddelde uitwijkmogelijkheden. Bij MBO Techniek hebben bijna alle opleidingstypen hogere uitwijkmogelijkheden in Overijssel. Bij MBO Dienstverlening en gezondheidszorg zijn er meer uitwijkmogelijkheden in Overijssel met $M B O$ verpleging, $M B O$ sociaal-cultureel, $M B O$ uiterlijke verzorging, $M B O$ horeca en $M B O$ beweging en therapie. Bij MBO Economie hebben de opleidingstypen $M B O$ secretariaat en $M B O$ administratie ruimere uitwijkmogelijkheden.

Al met al kan gesteld worden dat de uitwijkmogelijkheden in Overijssel groter zijn dan in Nederland. Omdat de curricula van MBO-opleidingen in Nederland voor een belangrijk deel landelijk worden vastgesteld, is het aannemelijk dat een gevarieerde beroepenstructuur in Overijssel ten opzichte van Nederland de oorzaak is van de grotere uitwijkmogelijkheden van schoolverlaters.

18. Zie verder de Statistische Bijlage van dit rapport voor een gedetailleerde weergave van de uitwijkmogelijkheden per opleidingstype van gediplomeerde schoolverlaters in Overijssel. 



\section{De vraag naar arbeidskrachten op de Overijsselse arbeidsmarkt}

De verwachte sectorale werkgelegenheidsgroei op de korte termijn verschilt duidelijk met die op de middellange termijn. Waar voor de korte termijn (2003-2004) een krimp van $-0,2 \%$ voorspeld wordt, is over de middellange termijn (2001-2006) een jaarlijkse groei van 0,4\% te verwachten. De bedrijfssectoren Landbouw, Energie, Bouw en alle industriesectoren vertonen zowel voor de korte als voor de lange termijn een krimp van het aantal werkenden. Vergeleken met de verwachting voor Nederland is die van Overijssel somberder voor deze sectoren; in deze verwachting voor Overijssel is echter de recente conjunctuurdip van lagere economische groei verwerkt. De uitbreidingsvraag tot 2006 in Overijssel is voor de krimpende bedrijfssectoren Landbouw en Bank- en verzekeringswezen iets beter dan de verwachting voor Nederland. Alle andere sectoren vertonen een lagere uitbreidingsvraag dan de Nederlandse prognoses, mede door de gewijzigde economische situatie.

De verwachte vervangingsvraag in Overijssel is vergelijkbaar met die in Nederland. Vooral beroepen waarin veel lager opgeleiden werkzaam zijn vertonen een hogere vervangingsvraag dan in Nederland. De vervangingsvraag voor de opleidingssectoren Basisonderwijs (ongeschoolden), VMBO en HAVONWO is over het algemeen hoog. Dit compenseert de lage uitbreidingsvraag voor deze opleidingssectoren. Onder hoger opgeleiden van het $\mathrm{HBO}$ is de vervangingsvraag vergelijkbaar met het Nederlandse gemiddelde, in tegenstelling tot de universitair opgeleiden. Deze laatste groep heeft een duidelijk lagere vervangingsvraag, hetgeen samenhangt met een relatief jonge leeftijdsopbouw in Overijssel.

Het aantal baanopeningen in Overijssel is voor een belangrijk deel een gevolg van de vervangingsvraag. Door de stagnerende economische groei en de achterblijvende groei van de werkgelegenheid is het aantal baanopeningen dat ontstaat door de uitbreidingsvraag - met name voor de ongeschoolden en lager opgeleiden - zeer beperkt. Door de hoge vervangingsvraag hebben ook beroepen en (lagere) opleidingen met een negatieve uitbreidingsvraag toch vaak een relatief groot aantal baanopeningen. Vaak zijn dit de beroepen of opleidingen die gekenmerkt worden door een hogere gemiddelde leeftijdsopbouw of door een groot personeelsverloop.

\subsection{Inleiding}

In dit hoofdstuk wordt nader ingegaan op de verwachte vraag- en aanbodontwikkelingen binnen de Overijsselse arbeidsmarkt op de korte en middellange termijn. Paragraaf 3.2 belicht de verwachte uitbreidingsvraag naar sector, beroep en opleiding. In paragraaf 3.3 wordt de vervangingsvraag naar beroep en opleiding besproken. Zowel bij de uitbreidings- als bij de vervangingsvraag zullen de hoofdlijnen per beroepsklasse en opleidingssector worden weergegeven. Ook de onderliggende beroepsgroepen en opleidingstypen met de grootste dan wel de kleinste verwachte groei (of krimp in het geval van negatieve groei) zullen apart worden besproken. De uitbreidings- en vervangingsvraag vormen tezamen de totale 
verwachte vraag naar nieuwe arbeidskrachten op de Overijsselse arbeidsmarkt. Deze prognose van het aantal baanopeningen wordt in paragraaf 3.4 gegeven naar zowel beroep als opleiding.

\subsection{Uitbreidingsvraag}

\section{Bedrijfssectoren}

De vraag naar schoolverlaters wordt door twee componenten bepaald; de uitbreidingsvraag ten gevolge van de verwachte werkgelegenheidsgroei en de vervangingsvraag veroorzaakt door (tijdelijke) uitstroom van reeds werkenden. In deze paragraaf bespreken we de uitkomsten van de eerste vraagcomponent: de uitbreidingsvraag. Tabel 3.1 geeft voor de verschillende sectoren de uitbreidingsvraag op de korte en middellange termijn weer als percentage van de werkgelegenheid in het basisjaar. ${ }^{19}$ Voor de middellange termijn worden deze gegevens tevens vergeleken met het landelijke beeld. ${ }^{20}$

De verwachting voor de korte termijn is dat de werkgelegenheid in Overijssel met gemiddeld $0,2 \%$ krimpt. Dit gemiddelde is een resultante van de verwachte werkgelegenheidsontwikkeling in de verschillende bedrijfssectoren. De krimp wordt met name veroorzaakt door de sectoren Landbouw, Energie, Bouw en onroerend goed en de industriële sectoren. De verwachte werkgelegenheidskrimp in de bedrijfssector Landbouw bedraagt op de korte termijn 1,6\%. Als gevolg van de conjunctuur is er eveneens een duidelijke krimp te verwachten voor de bedrijfssector Bouw en onroerend goed van $0,7 \%$, en voor de verschillende industriesectoren van $1,1 \%$ tot $1,8 \%$. De lage gemiddelde krimp van $0,2 \%$ is te danken aan de verwachte groei in de sectoren Bank- en verzekeringswezen en Overheid en onderwijs met ieder $0,6 \%$. Horeca en zakelijke dienstverlening evenals de Kwartaire diensten vertonen een groei van $0,5 \%$.

De groeiverwachtingen op de korte termijn verschillen duidelijk van de verwachtingen van de middellange termijn. Ook al manifesteert de krimp van de sectoren Landbouw en visserij, Voeding, Chemie, Metaal en elektrotechniek, Overige industrie, Energie, en Bouw en onroerend goed zich over de hele middellange termijn, toch overheerst de groei in de andere sectoren. In totaal wordt een jaarlijkse groei van 0,4\% verwacht voor de periode van 2001 tot 2006. Dit komt neer op een gemiddelde jaarlijkse uitbreidingsvraag van 2.050 werkenden.

De tabel laat voor de werkgelegenheidsgroei op zowel de korte als de middellange termijn duidelijk en tweedeling zien tussen enerzijds de verwachte werkgelegenheidskrimp (of bijna nulgroei) in de agrarische sectoren en de industriële sectoren, en

19. Voor de middellange termijn is - conform de landelijke voorspelling - voor de periode 2001-2006 gekozen, waarbij voor Overijssel het aantal baanopeningen is gepercenteerd op de werkgelegenheid in het basisjaar 2001. De kortetermijnprognoses geven de verwachtingen voor 2004 weer, waarbij de percentages zijn berekend op grond van de werkgelegenheid in het basisjaar 2003.

20. ROA (2001), De arbeidsmarkt naar opleiding en beroep tot 2006, ROA-R-2001/8, Maastricht. 
anderzijds de werkgelegenheidsgroei in de meeste dienstverlenende sectoren. Daarmee lijkt de werkgelegenheid in de dienstverlening beter bestand te zijn tegen de negatieve gevolgen van de tegenvallende conjuncturele ontwikkeling dan de werkgelegenheid in de industrie. Vooral de sectoren Horeca en zakelijke dienstverlening, Kwartaire dienstverlening (incl. gezondheidszorg) en Overheid en onderwijs zijn de banenmotor in Overijssel. Het Bank- en verzekeringswezen laat voor 2004 weliswaar een relatief hoge werkgelegenheidsgroei zien, maar over de hele middellange termijn krimpt de werkgelegenheid in deze sector.

Tabel 3.1

Verwachte uitbreidingsvraag naar bedrijfssector op korte en middellange termijn als percentage van de werkgelegenheid in het basisjaar, Overijssel

\begin{tabular}{|c|c|c|}
\hline Bedrijfssector & $\begin{array}{r}\text { Overijssel } \\
2003-2004 \\
\%\end{array}$ & $\begin{array}{r}\text { Overijssel } \\
2001-2006 \\
\text { Jaarlijks \% }\end{array}$ \\
\hline Landbouw en visserij & $-1,6$ & -1 \\
\hline Voeding & $-1,6$ & -0 \\
\hline Chemie & $-1,1$ & $-1,0$ \\
\hline Metaal en elektrotechniek & $-1,7$ & $-2,2$ \\
\hline Overige industrie & $-1,8$ & $-2,1$ \\
\hline Energie & $-0,4$ & $-0,7$ \\
\hline Bouw en onroerend goed & $-0,7$ & $-0,2$ \\
\hline Handel en reparatie & 0,0 & 0 , \\
\hline Transport en communicatie & 0,0 & 0 , \\
\hline Bank en verzekeringswezen & 0,6 & $-0,3$ \\
\hline Horeca en zakelijke dienstverlening & 0,5 & \\
\hline Kwartaire diensten & 0,5 & \\
\hline Overheid en onderwijs & 0,6 & \\
\hline Totaal & $-0,2$ & \\
\hline
\end{tabular}

Bron: CPB/Etil/ROA

Uit figuur 3.1 blijkt dat de verwachte werkgelegenheidsgroei voor Overijssel tot 2006 lager is dan de verwachte werkgelegenheidsgroei voor Nederland. ${ }^{21}$ Dit is mede terug te voeren op de inmiddels gewijzigde economische situatie, die voor de Overijsselse prognoses is meegenomen maar in de landelijke prognoses niet. De tegenvallende conjunctuur heeft met name een negatieve invloed gehad op de verwachte werkgelegenheidsontwikkeling in de sectoren Landbouw, Bank- en verzekeringswezen en in de industrie. De grootste werkgelegenheidskrimp in Overijssel wordt verwacht in de Metaal- en elektrotechniek en in de Overige industrie. Naar verwachting zal het aantal banen in deze bedrijfssectoren met meer dan een tiende worden gereduceerd tussen 2001 en 2006. Het Bank- en verzekeringswezen vertoont eveneens een negatieve uitbreidingsvraag. Deze is ongeveer gelijk voor Overijssel en Nederland.

21. De tabellen geven de gemiddelde jaarlijkse groei voor zowel de korte als ook de middellange termijn weer. In de figuren wordt de totale groei over de middellange termijn (vijf jaren) weergegeven. 
In figuur 3.1 zijn de verschillen tussen de Overijsselse sectoren voor de middellange termijn duidelijk te zien. Terwijl de sectoren Horeca en zakelijke dienstverlening, Kwartaire diensten, en Overheid en onderwijs duidelijk een positieve jaarlijkse uitbreidingsvraag vertonen, hebben met name de Landbouw en de industriesectoren te kampen met een negatieve uitbreidingsvraag.

Figuur 3.1

Verwachte uitbreidingsvraag naar bedrijfssector als percentage van de werkgelegenheid in het basisjaar, 2001-2006, Overijssel en Nederland

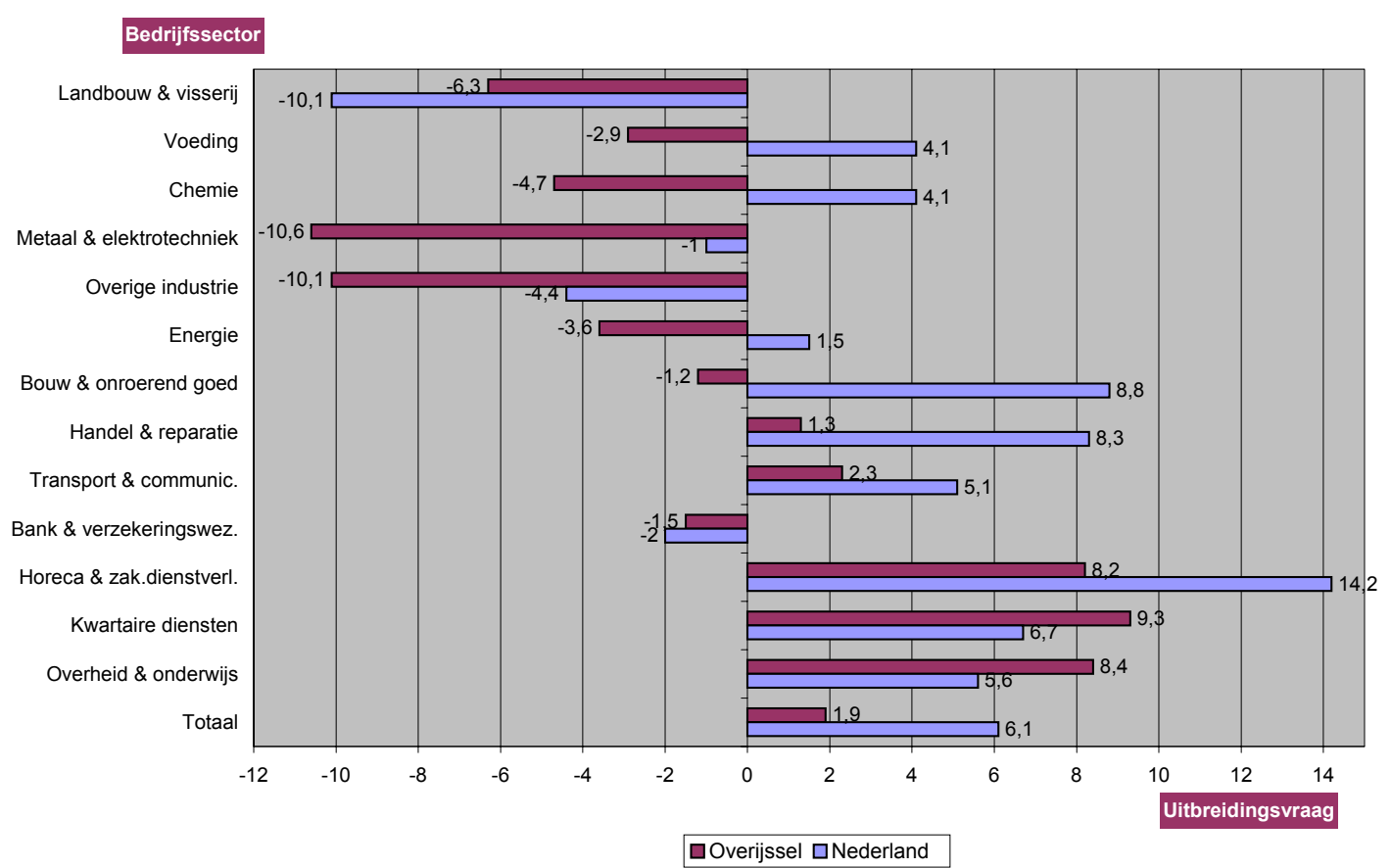

Bron: CPB/Etil/ROA

\section{Beroepsklassen}

De verwachte groei of krimp van de werkgelegenheid naar bedrijfssector heeft gevolgen voor de werkgelegenheid naar beroep. In tabel 3.2 wordt de uitbreidingsvraag naar beroepsklasse weergegeven. Op de korte termijn vertaalt zich de huidige economische situatie in negatieve uitbreidingsvraag voor meerdere beroepsklassen. Vooral de Openbare orde en veiligheidsberoepen, en in mindere mate de Agrarische beroepen en de Technische en industrieberoepen, laten een duidelijke krimp op de korte termijn zien. Opvallend is dat de krimp van de Openbare orde en veiligheidsberoepen duidelijk minder sterk is over de middellange termijn, terwijl voor de Agrarische beroepen en de Technische en industrieberoepen juist het tegendeel het geval is. Deze beroepsklassen vertonen op de middellange termijn een duidelijk hogere krimp. 
Tabel 3.2

Verwachte uitbreidingsvraag naar beroepsklasse op korte en middellange termijn als percentage van de werkgelegenheid in het basisjaar, Overijssel

\begin{tabular}{lrr} 
Beroepsklasse & Overijssel & $\begin{array}{r}\text { Overijssel } \\
2001-2006\end{array}$ \\
& $2003-2004$ & Jaarlijks \% \\
& & \\
\hline & & 1,0 \\
Pedagogische beroepen & $-0,3$ & 1,2 \\
Culturele beroepen & 0,4 & $-1,4$ \\
Agrarische beroepen & $-1,0$ & $-1,4$ \\
Technische en industrieberoepen & $-0,6$ & $-0,5$ \\
Transportberoepen & $-0,4$ & 1,2 \\
Medische en paramedische beroepen & 0,4 & 1,5 \\
Economisch-administratieve beroepen & 0,6 & 2,4 \\
Informaticaberoepen & 2,9 & 3,6 \\
Sociaal-culturele beroepen & 1,6 & $-0,1$ \\
Verzorgende en dienstverlenende beroepen & $-0,2$ & $-0,7$ \\
Openbare orde- en veiligheidsberoepen & $-6,2$ & 0,4 \\
& & $-1,4$ \\
Totaal & $-0,2$ & \\
\end{tabular}

Bron: CPB/Etil/ROA

Een positieve uitbreidingsvraag is te vinden bij de Culturele beroepen, de Medische en paramedische beroepen, de Economisch-administratieve beroepen, de Informaticaberoepen en de Sociaal-culturele beroepen. De laatste twee groepen vertonen de grootste procentuele uitbreidingsvraag, zowel voor de korte termijn als voor de middellange termijn.

In figuur 3.2 worden de middellangetermijnverwachtingen voor de uitbreidingsvraag naar beroep tussen Overijssel en Nederland vergeleken. De uitbreidingsvraag voor de Agrarische beroepen in Nederland is komt nog redelijk overeen met die in Overijssel. Overijssel toont - op middellange termijn - zelfs vijftiende procent minder krimp. De Industrieberoepen en de Openbare orde beroepen vertonen echter meer krimp dan voor Nederland verwacht wordt. Ook is de uitbreidingsvraag in Nederland hoger in de Economisch-administratieve beroepen en in de Informaticaberoepen. Overijssel heeft wel een hogere uitbreidingsvraag voor de Medische en paramedische beroepen en voor de Sociaal-culturele beroepen. Opvallend is verder dat voor de Transportberoepen in Nederland een positieve uitbreidingsvraag wordt voorzien, terwijl voor deze beroepen in Overijssel een krimp wordt verwacht.

De verwachte uitbreidingsvraag voor de Informatica beroepen in Overijssel is op middellange termijn lager dan voor Nederland. Dit ondanks het feit dat deze beroepen op dit moment mede de grootste uitbreidingsvraag voor Overijssel vertonen. Waarschijnlijk zijn de slechtere economische vooruitzichten die in de Overijsselse prognose zijn meegenomen, hier de oorzaak van. 
Figuur 3.2

Verwachte uitbreidingsvraag naar beroepsklasse als percentage van de werkgelegenheid in het basisjaar, 2001-2006, Overijssel en Nederland

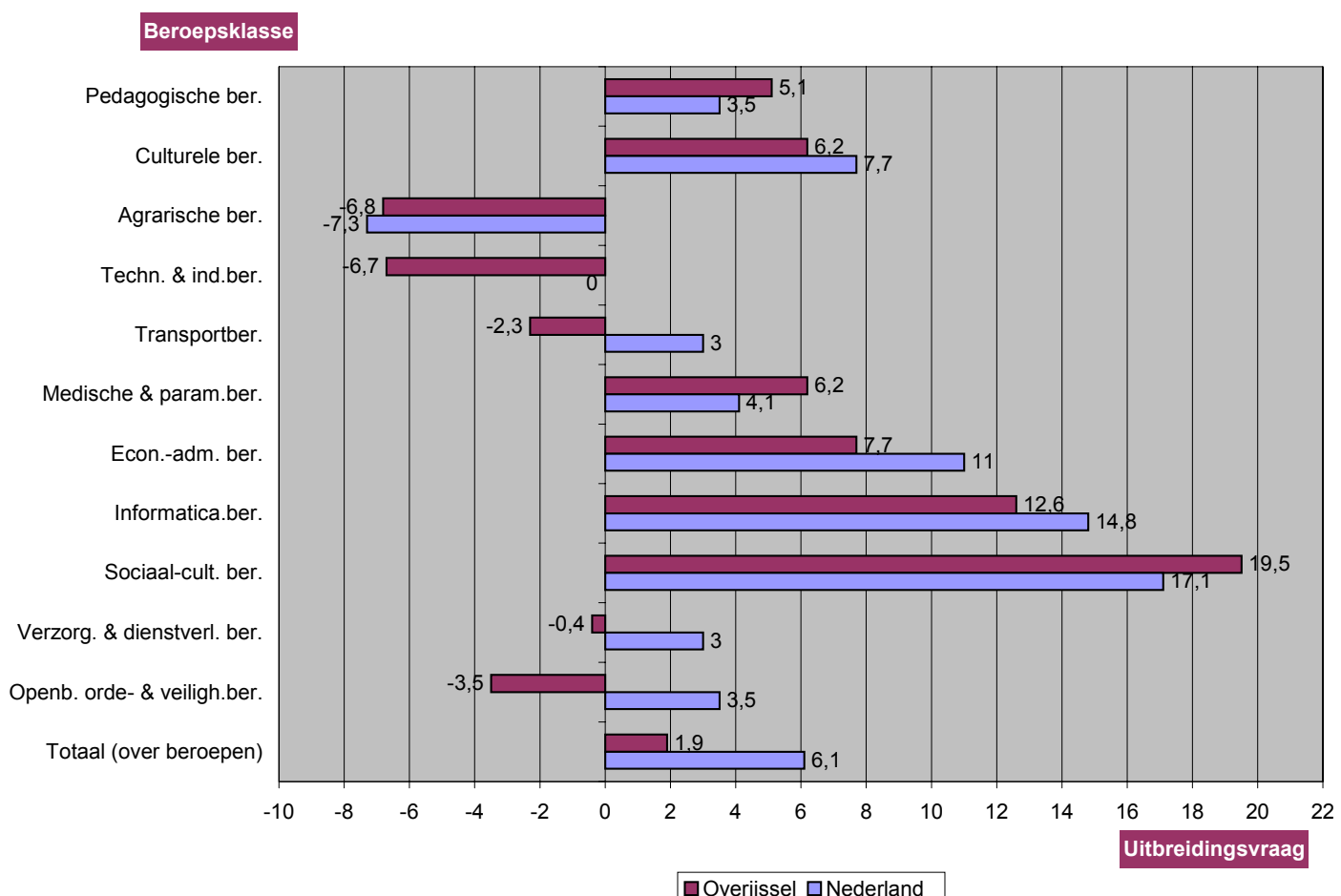

Bron: CPB/Etil/ROA

Aangezien de vooruitzichten voor een beroepsklasse niet noodzakelijkerwijs hoeven te gelden voor alle onderliggende beroepsgroepen, zijn in het volgende kader de meest opvallende uitkomsten op beroepsgroepenniveau weergegeven. ${ }^{22}$ Voor de korte termijn wordt voorzien dat juridisch en fiscaal medewerkers en technische systeemanalisten de hoogste uitbreidingsvraag hebben. Een lage uitbreidingsvraag voor de korte termijn wordt verwacht voor de monteurs en werktuigbouwkundige ontwerpers en hoofden technische dienst, beroepen die onder de krimpende Technische en industrieberoepen vallen. Het is ook niet verrassend om beroepen uit de Openbare orde en veiligheidsberoepen in deze lijst terug te vinden: aspirant politieagenten, soldaten en beveiligingshulpen, en op een hoger beroepsniveau agenten, onderofficieren en beveiligingsemployés.

22. Voor het complete overzicht van korte- en middellangetermijnprognoses op dit lagere aggregatieniveau wordt verwezen naar de bij dit rapport verschenen Statistische Bijlage. 


\section{KORTE TERMIJN}

\section{Beroepsgroepen met een relatief hoge uitbreidingsvraag in Overijssel:}

- Juridisch en fiscaal medewerkers

- Technisch systeemanalisten

Beroepsgroepen met een relatief lage uitbreidingsvraag in Overijssel:

- Monteurs

- Kunstenaars

- Werktuigbouwkundige ontwerpers en hoofden technische dienst

- Leraar basisonderwijs

- Receptionisten en administratieve employés

- Aspiranten politieagenten, soldaten en beveiligingshulpen

- Agenten, onderofficieren en beveiligingsemployés

\section{MIDDELLANGE TERMIJN}

Beroepsgroepen met een relatief hoge uitbreidingsvraag in Overijssel:

- Accountants

- Leidinggevenden

- Act. Begeleiders en medewerkers arbeidsbemiddeling

- Managers

- Productieplanners

- Organisatieadviseurs

- Ziekenverzorgenden

Beroepsgroepen met een relatief lage uitbreidingsvraag in Overijssel:

- Receptionisten en administratieve employés

- Bouwvakkers

- Agrarische arbeiders

- Conciërges

- Hulpkrachten horeca en verzorging

- Verzekeringsagenten

- Docenten talen en expressie

- Agenten, onderofficieren en beveiligingsemployés

Op de middellange termijn zijn de vooruitzichten goed voor gespecialiseerde bedrijfseconomische beroepen zoals accountants, maar ook voor managers en organisatieadviseurs. Het is echter nog onduidelijk hoe de toekomstige economische situatie zich vertaalt voor deze beroepsgroepen op de langere termijn. Relatief laag is de uitbreidingsvraag voor lager geschoolde krachten zoals receptionisten en administratieve employés, conciërges, en hulpkrachten horeca en verzorging. Ook bouw- 
vakkers zullen op de middellange termijn met de teruglopende vooruitzichten voor de bouwsector te kampen krijgen.

\section{Opleidingssectoren}

De vraag naar arbeidskrachten in een bepaald beroep kan ook worden voorgesteld als de vraag naar mensen met een bepaalde opleidingsachtergrond. Tabel 3.3 geeft een overzicht van de verwachte uitbreidingsvraag naar opleidingssector voor Overijssel. De uitbreidingsvraag voor de lagere opleidingniveaus is zowel op de korte als op de middellange termijn negatief. Terwijl voor de korte termijn prognose met een krimp tussen $-1,1 \%$ en $-1,8 \%$ voor Basisonderwijs en de verschillende VMBO opleidingen gerekend moet worden, wordt deze krimp voor de middellange termijn zelfs groter. De verwachte krimp in de werkgelegenheid op de middellange termijn bedraagt $-5.6 \%$ voor Basisonderwijs en zelfs $-7.9 \%$ voor VMBO Landbouw. Daar tegenover staat een positieve uitbreidingsvraag voor hogere opleidingen (HBO en WO). Hier neemt de werkgelegenheid naar verwachting toe met in totaal 17.000 personen over een periode van vijf jaar.

Tabel 3.3

Verwachte uitbreidingsvraag naar opleidingssector op korte en middellange termijn als percentage van de werkgelegenheid in het basisjaar, Overijssel

\begin{tabular}{|c|c|c|}
\hline & $\begin{array}{r}\text { Overijssel } \\
2003-2004 \\
\%\end{array}$ & $\begin{array}{l}\text { Overijssel } \\
2001-2006 \\
\text { Jaarlijks \% }\end{array}$ \\
\hline Basisonderwijs & $-1,2$ & $-5,6$ \\
\hline VMBO Theorie & $-1,4$ & $-1,0$ \\
\hline VMBO Landbouw & $-1,1$ & $-7,9$ \\
\hline VMBO Techniek & $-1,2$ & $-3,4$ \\
\hline VMBO Economie & $-1,3$ & $-2,4$ \\
\hline VMBO Verzorging & $-1,8$ & $-2,7$ \\
\hline HAVO/VWO & $-0,2$ & 2,2 \\
\hline MBO Landbouw & $-0,9$ & 2,4 \\
\hline MBO Techniek & $-0,2$ & $\overrightarrow{0,8}$ \\
\hline MBO Economie & 0,1 & 0,8 \\
\hline MBO Dienstverlening en gezondheidszorg & 0,1 & 1,0 \\
\hline HBO Landbouw & 0,6 & 2,2 \\
\hline HBO Techniek & 1,2 & 1,4 \\
\hline HBO Economie & 1,3 & 3,0 \\
\hline HBO Onderwijs en sociaal-cultureel & 0,1 & 1,7 \\
\hline HBO Paramedisch & 0,8 & 4,3 \\
\hline WO Landbouw & - & - \\
\hline WO Techniek & 0,7 & 2,2 \\
\hline WO Economie & 1,3 & 4,5 \\
\hline WO Letteren en sociaal-cultureel & 1,2 & 3,8 \\
\hline WO Medisch & 1,7 & 0,9 \\
\hline Totaal & $-0,2$ & 0,4 \\
\hline
\end{tabular}

Bron: CPB/Etil/ROA

Ook in figuur 3.3 is te zien dat de vooruitzichten wat betreft de uitbreidingsvraag voor de middellange termijn met name voor de ongeschoolden en de lager opgeleiden duidelijk slechter zijn voor Overijssel dan voor Nederland. Vergeleken met de verwachting voor Nederland, waar de tweedeling in verwachte werkgelegenheids- 
groei al te zien was, is de tweedeling tussen enerzijds hoge en middelbare opleidingen en anderzijds lage opleidingen in Overijssel nog scherper.

\section{Figuur 3.3}

Verwachte uitbreidingsvraag naar opleidingssector als percentage van de werkgelegenheid in het basisjaar, 2001-2006, Overijssel en Nederland

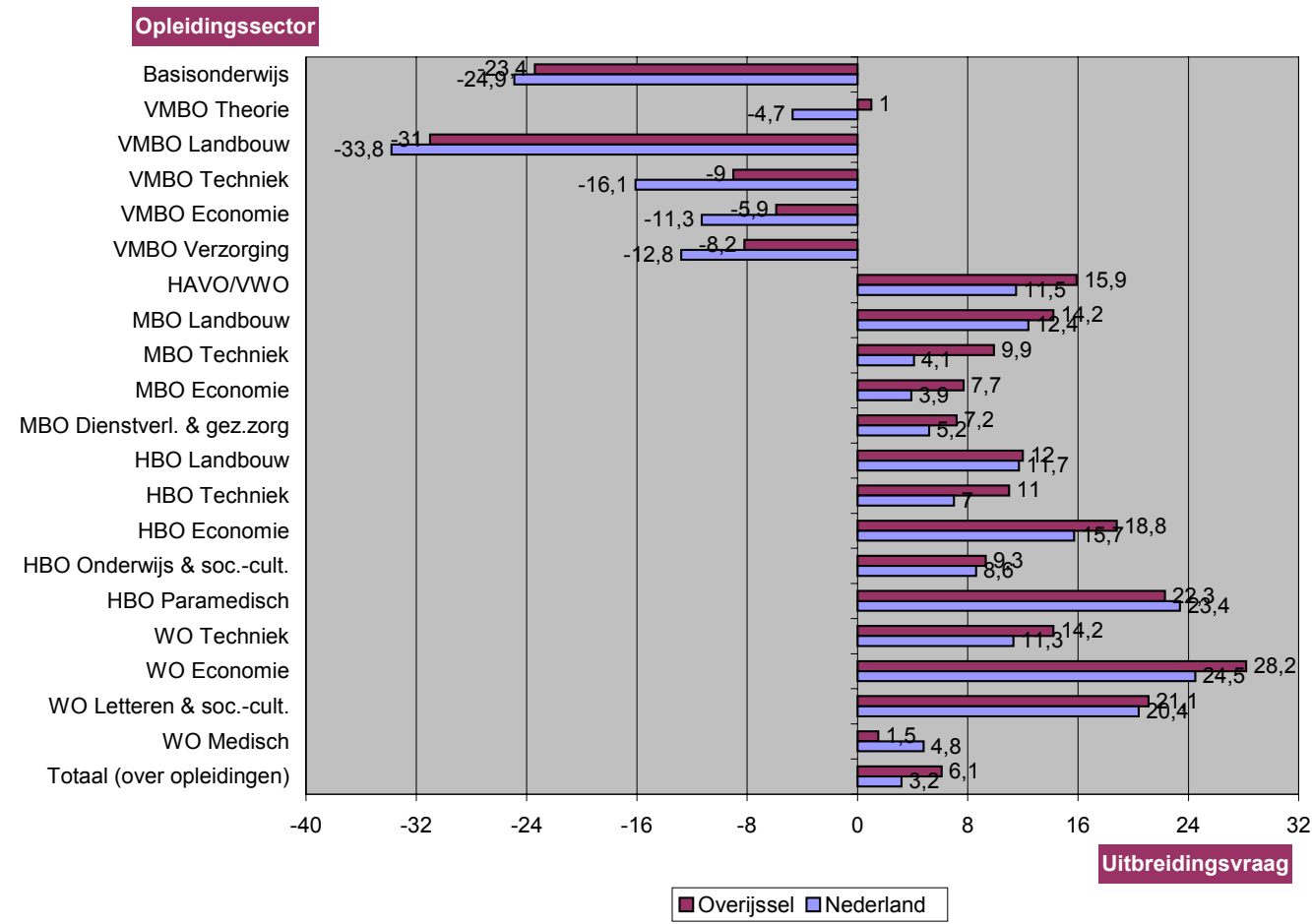

Bron: CPB/Etil/ROA

In het volgende kader worden de meest opvallende uitkomsten voor de opleidingstypen weergegeven. Duidelijk is te zien dat de hogere opleidingen een positieve uitbreidingsvraag kunnen verwachten, met name in de opleidingssectoren waarvoor eveneens een positieve uitbreidingsvraag wordt verwacht. Een lage uitbreidingsvraag echter, is zowel op korte als op middellange termijn, onder opleidingstypen van het lagere opleidingsniveau te vinden. 


\section{KORTE TERMIJN}

Opleidingstypen met een relatief hoge uitbreidingsvraag in Overijssel:

- HBO laboratorium

- HBO maatschappelijk werk en hulpverlening

- WO (dier)geneeskunde

- HBO informatica

- HBO commerciële economie

- HBO bedrijfskunde

Opleidingstypen met een relatief lage uitbreidingsvraag in Overijssel:

- VMBO verzorging

- VMBO bouwtechniek

- VMBO theorie

- VMBO administratie, handel en textiel

\section{MIDDELLANGE TERMIJN}

Opleidingstypen met een relatief hoge uitbreidingsvraag in Overijssel:

- MBO techniek overig

- HBO overig

- WO bedrijfskunde

- WO econom(etr)ie

Opleidingstypen met een relatief lage uitbreidingsvraag in Overijssel:

- VMBO landbouw en natuurlijke omgeving

- VMBO administratie, handel en textiel

- Basisonderwijs

- VMBO mechanische techniek

- $\mathrm{MBO}$ geld, bank en belastingen

\subsection{Vervangingsvraag}

In deze paragraaf wordt de verwachte vervangingsvraag naar beroep en opleiding weergegeven. De vervangingsvraag is de vraag naar arbeidskrachten welke voortvloeit uit het vertrek van werkenden. Deze werkenden kunnen om een breed scala aan redenen besluiten al dan niet tijdelijk de arbeidsmarkt te verlaten. Hierbij kan gedacht worden aan pensioen, VUT, arbeidsongeschiktheid, zorgtaken enzovoorts. Andere oorzaken van vervangingsvraag zijn baan-baanmobiliteit van werkenden tussen beroepsgroepen en cursussen of opleidingstrajecten die leiden tot een verandering in de opleidingsachtergrond van werkenden. Een werkgever moet deze vertrekkende werknemers vervangen, tenzij er sprake is van een reductie van het aantal arbeidsplaatsen. 


\section{Beroepsklassen}

Tabel 3.4 geeft een overzicht van de verwachte vervangingsvraag per beroepsklasse voor Overijssel op de korte en middellange termijn. De gemiddelde jaarlijkse vervangingsvraag als percentage van de werkgelegenheid zijn voor de korte en middellange termijn vrijwel gelijk. De vervangingsvraag wordt voor een belangrijk deel bepaald door de samenstelling van het personeelsbestand, die meestal niet erg sterk zal veranderen in de loop van een aantal jaren. ${ }^{23}$ De leeftijd- en geslachtsopbouw van de werkenden binnen de beroepsklasse zijn voor een belangrijk deel verantwoordelijk voor de verwachte uittrede uit de arbeidsmarkt. Wanneer een beroepsklasse getypeerd wordt door een groot aandeel ouderen tegen de VUT- en pensioengerechtigde leeftijd, ligt het in de lijn der verwachting dat deze beroepsklasse een relatief grote vervangingsvraag zal kennen.

Tabel 3.4

Verwachte vervangingsvraag naar beroepsklasse op korte en middellange termijn als percentage van de werkgelegenheid in het basisjaar, Overijssel

\begin{tabular}{lrr} 
Beroepsklasse & Overijssel & Overijssel \\
& $2003-2004-2006$ \\
& $\%$ & Jaarlijks $\%$ \\
\hline & & 4,3 \\
Pedagogische beroepen & 4,5 & 3,2 \\
Culturele beroepen & 3,3 & 5,2 \\
Agrarische beroepen & 6,0 & 3,6 \\
Technische en industrieberoepen & 4,0 & 3,4 \\
Transportberoepen & 3,7 & 2,1 \\
Medische en paramedische beroepen & 2,0 & 2,2 \\
Economisch-administratieve beroepen & 2,3 & 1,2 \\
Informaticaberoepen & 1,3 & 2,8 \\
Sociaal-culturele beroepen & 2,9 & 3,1 \\
Verzorgende en dienstverlenende beroepen & 3,3 & 4,4 \\
Openbare orde- en veiligheidsberoepen & 4,7 & 3,0 \\
Totaal (over beroepen) & & 3,1 \\
\end{tabular}

Bron: ROA

In figuur 3.4 wordt de vervangingsvraag voor de middellange termijn vergeleken met de desbetreffende middellangetermijnprognoses voor Nederland. In de figuur is te zien dat Overijssel over het algemeen een met Nederland vergelijkbare vervangingsvraag tegemoet kan zien. De Medische en paramedische beroepen, de Economischadministratieve beroepen en de Informaticaberoepen hebben op de middellange termijn een duidelijk lagere vervangingsvraag in Overijssel dan in Nederland. Alle andere beroepsklassen hebben een hogere vervangingsvraag voor de middellange termijn. Vooral de Agrarische beroepen en de Openbare orde- en veiligheidsberoepen laten een duidelijk hogere vervangingsvraag zien. Voor de Agrarische beroepen en de Pedagogische beroepen geldt verder dat de relatief hoge ver-

23. Zie voor een beschouwing over de samenhang tussen de vervangingsvraag en de opbouw van het personeelsbestand ook hoofdstuk 5 van De arbeidsmarkt naar opleiding en beroep tot 2006 (ROA, 2001). Voorts wordt er in dat hoofdstuk ook ingegaan op de relatie tussen arbeidsomstandigheden en vervangingsvraag. 
vangingsvraag mede voortkomt uit de arbeidsomstandigheden. Ook bij de Openbare orde- en veiligheidsberoepen leidt een groter verloop - waaronder ook een carrière met een andere, betere functie in de beveiligingssector - tot deze hogere vervangingsvraag.

Figuur 3.4

Verwachte vervangingsvraag naar beroepsklasse, 2001-2006, Overijssel en Nederland

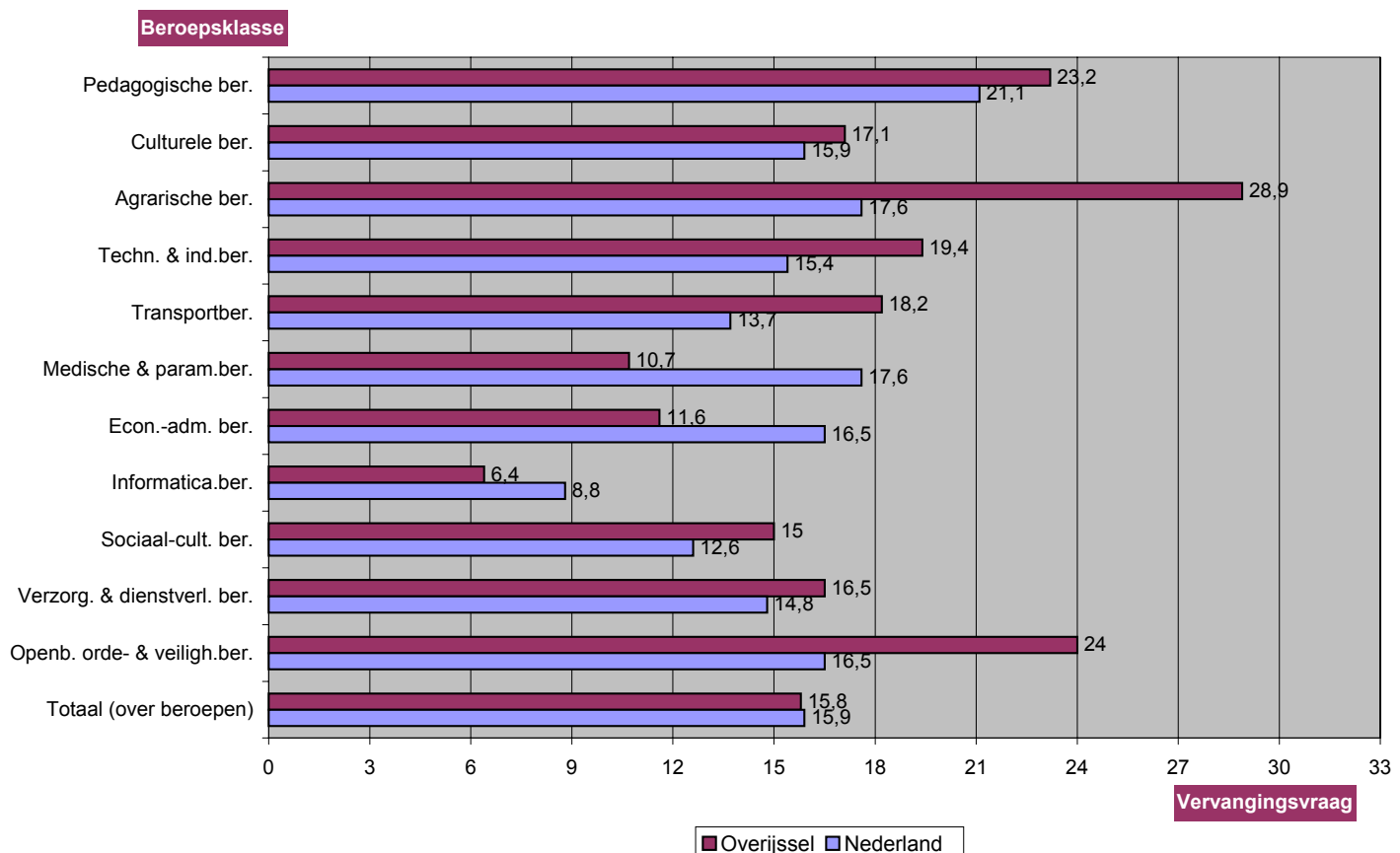

Bron: ROA

Het volgende kader geeft wederom enkele beroepsgroepen weer die op de korte en middellange termijn een erg hoge of lage vervangingsvraag te verwachten hebben. Opvallend is dat alle beroepsgroepen die een erg hoge vervangingsvraag voor de korte termijn hebben, deze ook op de middellange termijn vertonen. Hetzelfde is te zien onder de beroepen die een erg lage vervangingsvraag hebben. Dit heeft te maken met de leeftijdsopbouw van deze beroepen, maar ook met het verloop in een beroepsgroep. Agrarische bedrijfshoofden, weg- en waterbouwkundige vakkrachten, en ook conciërges zijn beroepen met een hoog percentage ouderen. In mindere mate is dit het geval voor juridisch en fiscaal medewerkers. Daarentegen wordt er in de beroepsgroep van aspirant politieagenten, soldaten en beveiligingshulpen vaak een overstap gemaakt naar een hogere functie binnen het normale carrièreverloop. Deze beroepsgroep wordt dan ook gekenmerkt door een jonge leeftijdsopbouw.

Systeemanalisten en in mindere mate ook assistent accountants zijn ook beroepen met een jonge leeftijdsopbouw. Daardoor mag voor deze groep een erg lage vervangingsvraag voor de korte en de middellange termijn worden verwacht. 


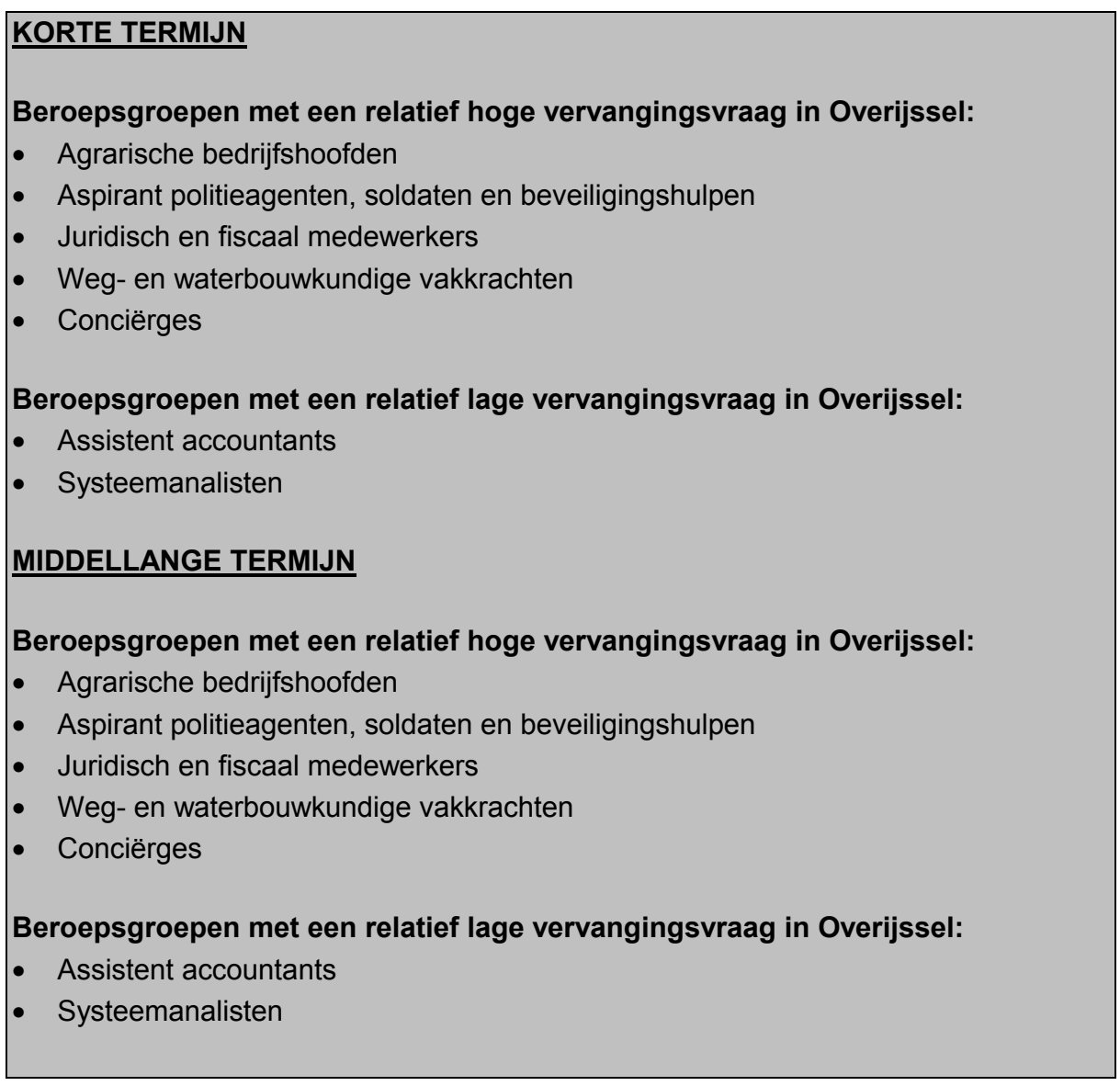

\section{Opleidingssectoren}

Vertaald naar opleidingssectoren is voor Overijssel een iets hogere vervangingsvraag te vinden dan die voor Nederland als geheel. Dit komt mede door de hogere vervangingsvraag onder de lagere opleidingen. De hoger opgeleiden hebben een vervangingsvraag die vergelijkbaar is met de Nederlandse situatie en zijn dus niet verantwoordelijk voor de relatief hoge vervangingsvraag naar opleiding in Overijssel.

Opvallend in figuur 3.5 is dat de universitair opgeleiden in Overijssel een duidelijk lagere vervangingsvraag hebben dan voor Nederland. Dit duidt erop dat gedurende de laatste jaren waarschijnlijk meer universitair opgeleiden in Overijssel in dienst genomen werden, en de gemiddelde leeftijdsopbouw derhalve onder het Nederlandse gemiddelde ligt. Het tegendeel lijkt het geval te zijn onder de lagere opgeleiden met $V M B O$ of een vergelijkbare opleiding. Hier heeft Overijssel een duidelijk hogere vervangingsvraag. 
Figuur 3.5

Verwachte vervangingsvraag naar opleidingssector als percentage van de werkgelegenheid in het basisjaar, 2001-2006, Overijssel en Nederland

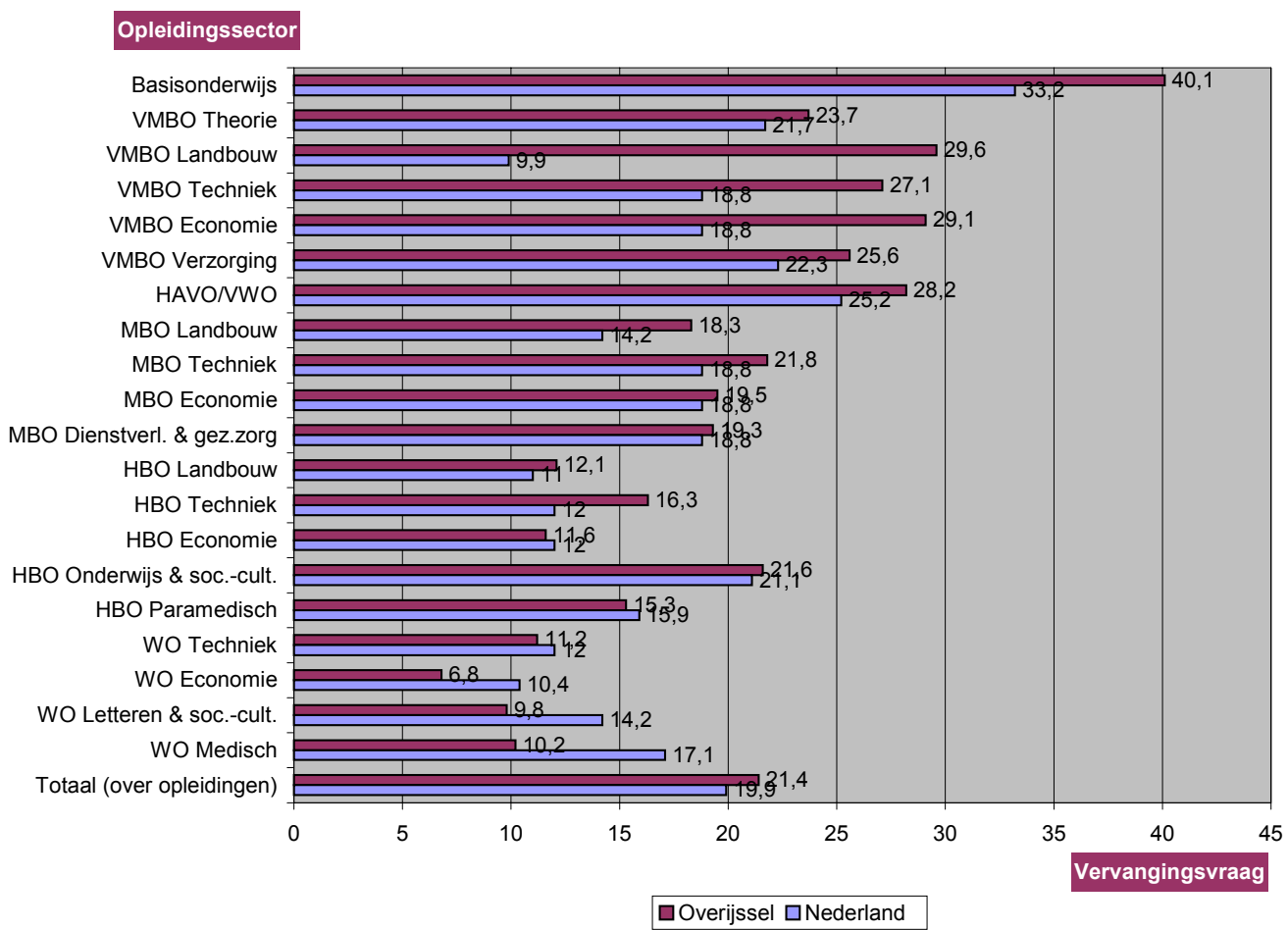

Bron: ROA

Tabel 3.5

Verwachte vervangingsvraag naar opleidingssector op korte en middellange termijn, Overijssel

\begin{tabular}{lrr} 
Opleidingssector & $\begin{array}{r}\text { Overijssel } \\
2003-2004 \\
\%\end{array}$ & $\begin{array}{r}\text { Overijssel } \\
2001-2006 \\
\text { Jaarlijks \% }\end{array}$ \\
\hline Basisonderwijs & 7,7 & 7,0 \\
VMBO Theorie & 4,6 & 4,3 \\
VMBO Landbouw & 5,9 & 5,3 \\
VMBO Techniek & 5,4 & 4,9 \\
VMBO Economie & 5,7 & 5,2 \\
VMBO Verzorging & 4,9 & 4,7 \\
HAVO/VWO & 5,6 & 5,1 \\
MBO Landbouw & 3,8 & 3,4 \\
MBO Techniek & 4,4 & 4,0 \\
MBO Economie & 4,0 & 3,6 \\
MBO Dienstverlening en gezondheidszorg & 3,9 & 3,6 \\
HBO Landbouw & 2,5 & 2,3
\end{tabular}


Tabel 3.5 (vervolg)

Verwachte vervangingsvraag naar opleidingssector op korte en middellange termijn, Overijssel

\begin{tabular}{lrr}
\hline Opleidingssector & Overijssel & $\begin{array}{r}\text { Overijssel } \\
2001-2006 \\
\text { Jaarlijks \% }\end{array}$ \\
& $2003-2004$ & 3,1 \\
& $\%$ & 2,2 \\
HBO Techniek & & 4,0 \\
HBO Economie & 3,3 & 2,9 \\
HBO Onderwijs en sociaal-cultureel & 2,3 & - \\
HBO Paramedisch & 4,3 & 2,1 \\
WO Landbouw & 3,1 & 1,3 \\
WO Techniek & - & 1,9 \\
WO Economie & 2,1 & 2,0 \\
WO Letteren en sociaal-cultureel & 1,4 & 1,9 \\
WO Medisch & 2,0 & 4,0 \\
Totaal (over opleidingen) & & ., \\
\end{tabular}

Bron: ROA

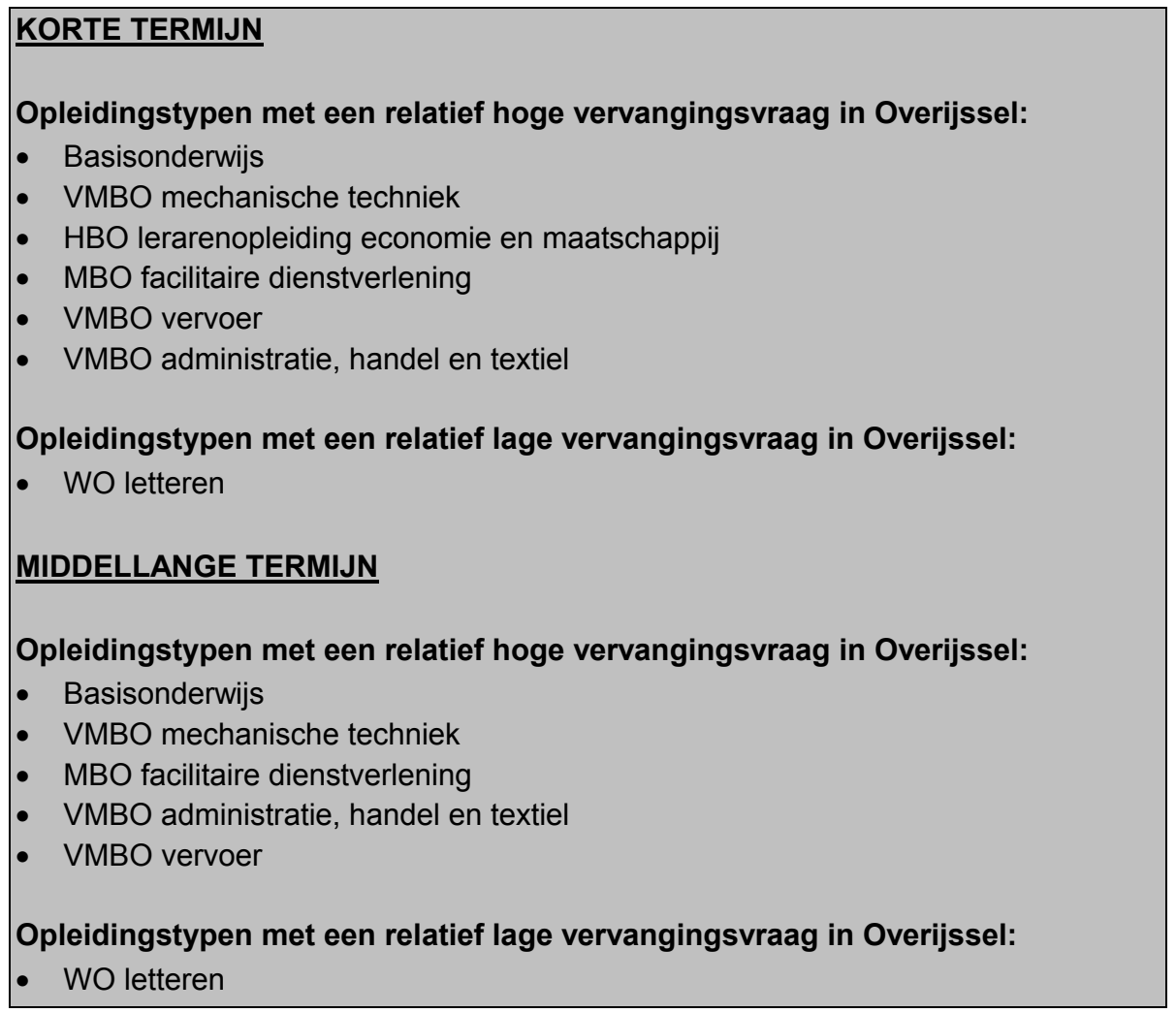

In het bovenstaande kader is een aantal opleidingstypen met relatief veel of weinig vervangingsvraag in Overijssel weergegeven. Veel vervangingsvraag is onder de lage opleidingen te vinden. Eén uitzondering is $H B O$ lerarenopleiding economie en maatschappij, waarvoor op de korte termijn ook een hoge vervangingsvraag 
voorspeld wordt. WO letteren heeft een erg lage vervangingsvraag zowel op korte als op middellange termijn.

\subsection{Baanopeningen}

Wanneer we de prognoses van de uitbreidingsvraag en de vervangingsvraag sommeren, dan geeft dit een indicatie van de totale verwachte vraag naar de baanopeningen voor nieuwkomers op de Overijsselse arbeidsmarkt. Bij een krimpende werkgelegenheid bestaan de baanopeningen alleen uit de vervangingsvraag. ${ }^{24}$ Voor zover het vertrek van werkenden leidt tot het aantrekken van nieuwe arbeidskrachten draagt deze vervangingsvraag bij aan het aantal baanopeningen.

\section{Beroepsklassen}

Tabel 3.6 geeft een overzicht van de totale vraag naar beroepsklasse voor Overijssel. De combinatie van uitbreidingsvraag en vervangingsvraag leidt op korte termijn tot veel baanopeningen bij de Culturele en de Pedagogische beroepen. Deze vertonen op korte termijn een veel hoger percentage baanopeningen dan gemiddeld over vijf jaar voor Nederland wordt verwacht. Ook over de middellange termijn in Overijssel vertonen deze twee beroepsklassen een hoog percentage aan baanopeningen.

Tabel 3.6

Verwachte baanopeningen naar beroepsklasse op korte en middellange termijn, Overijssel

\begin{tabular}{lrr} 
& Overijssel & Overijssel \\
& $2003-2004$ & $2001-2006$ \\
& $\%$ & Jaarlijks \% \\
\hline & & \\
\hline Pedagogische beroepen & 7,3 & 5,3 \\
Culturele beroepen & 9,3 & 4,6 \\
Agrarische beroepen & 6,1 & 5,3 \\
Technische en industrieberoepen & 6,2 & 3,8 \\
Transportberoepen & 4,0 & 3,5 \\
Medische en paramedische beroepen & 3,0 & 3,4 \\
Economisch-administratieve beroepen & 4,1 & 4,0 \\
Informaticaberoepen & 4,3 & 3,6 \\
Sociaal-culturele beroepen & 5,5 & 6,1 \\
Verzorgende en dienstverlenende beroepen & 4,4 & 3,5 \\
Openbare orde- en veiligheidsberoepen & 4,7 & 4,5 \\
& & 4,0 \\
Totaal (over beroepen) & 5,0 &
\end{tabular}

\section{Bron: ROA}

24. Het blijkt dat werkgevers voor het realiseren van een teruglopende vraag naar arbeid aan de 'exit'-optie de voorkeur geven boven de 'no entry'-optie van bijvoorbeeld schoolverlaters (E. Willems, L. Borghans en A. de Grip (1997), Exit or no entry? Replacement demand and shrinking employment, ROA, Paper for the EALE conference, Aarhus, Denmark). Bij het vaststellen van het aantal baanopeningen wordt ermee rekening gehouden dat het aannemen van schoolverlaters door bedrijven en instellingen ('de vraag naar schoolverlaters') op nagenoeg hetzelfde niveau blijt ondanks een eventuele werkgelegenheidskrimp vanwege de extra uitstroom van ouderen. Een werkgelegenheidskrimp voor een opleidingstype of beroepsgroep gaat derhalve nauwelijks ten koste van de vervangingsvraag of het aantal baanopeningen in een opleidingstype of beroepsgroep. 
Opvallend is ook het relatief hoge percentage baanopeningen op de korte termijn voor de Technische en industrieberoepen. Dit vindt zijn oorzaak in de hoge vervangingsvraag in 2004.

In figuur 3.6 is duidelijk te zien dat - mede dankzij de hoge vervangingsvraag Overijssel redelijk hoge percentages baanopeningen heeft. Het blijkt dat vooral de Agrarische beroepen, de Sociaal-culturele beroepen, en de Openbare orde- en veiligheidsberoepen hogere percentages aan baanopeningen vertonen dan het landelijke beeld. Daarentegen zijn de baanopeningen onder Medische en paramedische beroepen, Economisch-administratieve beroepen, en Informaticaberoepen beduidend lager.

\section{Figuur 3.6}

Verwachte baanopeningen naar beroepsklasse als percentage van de werkgelegenheid in het basisjaar, 2001-2006, Overijssel en Nederland

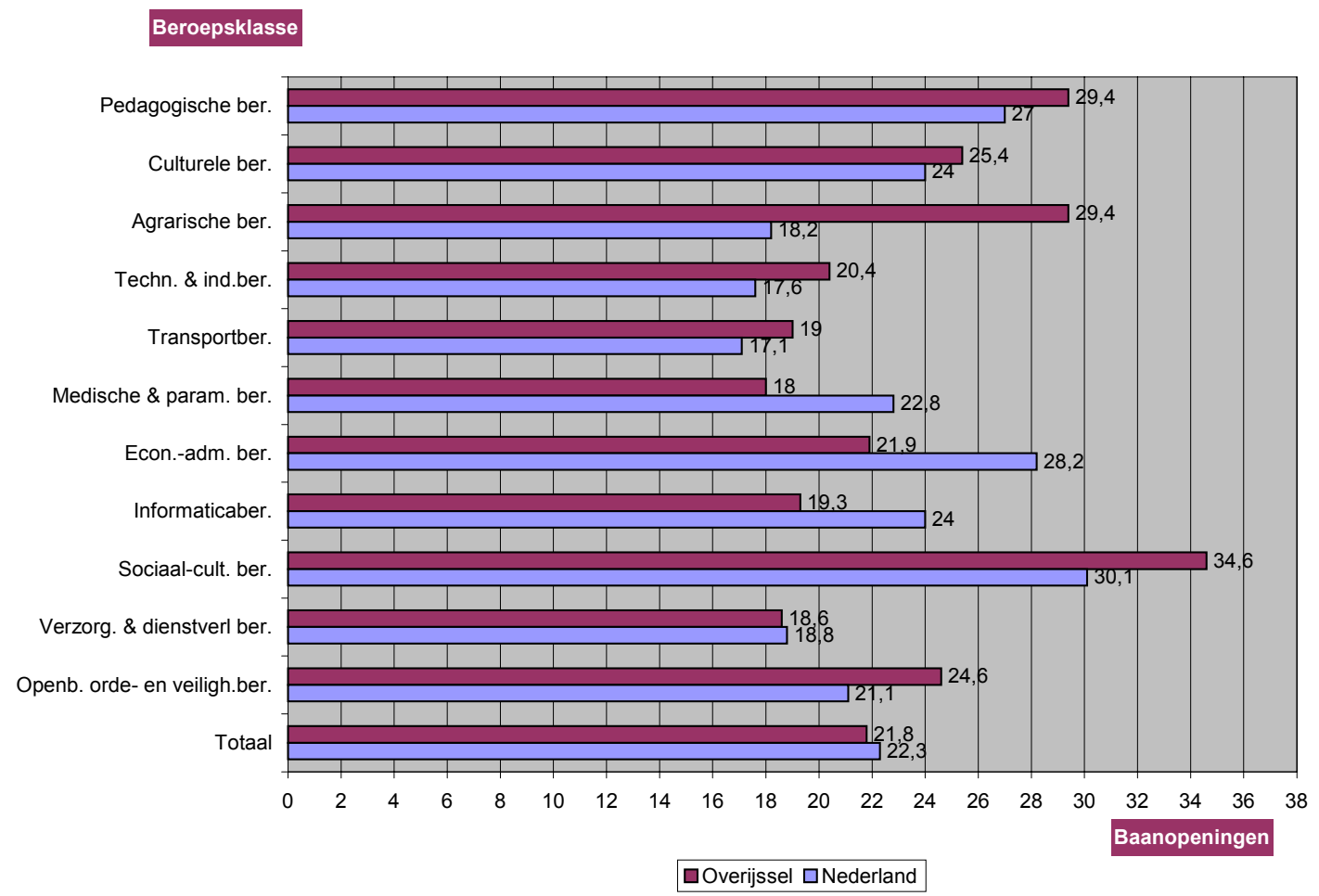

Bron: ROA

Voor sommige beroepsklassen vormt de uitbreidingsvraag de voornaamste bron van vraag naar nieuwe arbeidskrachten, voor andere is juist de vervangingsvraag van groter belang. Figuur 3.7 geeft per beroepsklasse het aandeel van uitbreidingsvraag en vervangingsvraag in de baanopeningen op de middellange termijn voor Overijssel weer. 
Gemiddeld genomen is de vervangingsvraag met een aandeel van $89,5 \%$ de belangrijkste component van de vraag naar nieuwe arbeidskrachten per beroep. Gezien de economische omstandigheden is het te verwachten dat veel baanopeningen voornamelijk door de vervangingsvraag tot stand komen. Er zijn opvallend veel beroepsklassen waarvoor de vervangingsvraag driekwart of meer van de baanopeningen voor zijn rekening neemt. In sommige beroepsklassen zijn de baanopeningen volledig terug te voeren op de vervangingsvraag, omdat de uitbreidingsvraag negatief is. Dit is een typisch gevolg van de economische situatie.

Figuur 3.7

Aandeel positieve uitbreidingsvraag en vervangingsvraag in de totale vraag, 2001-2006, Overijssel

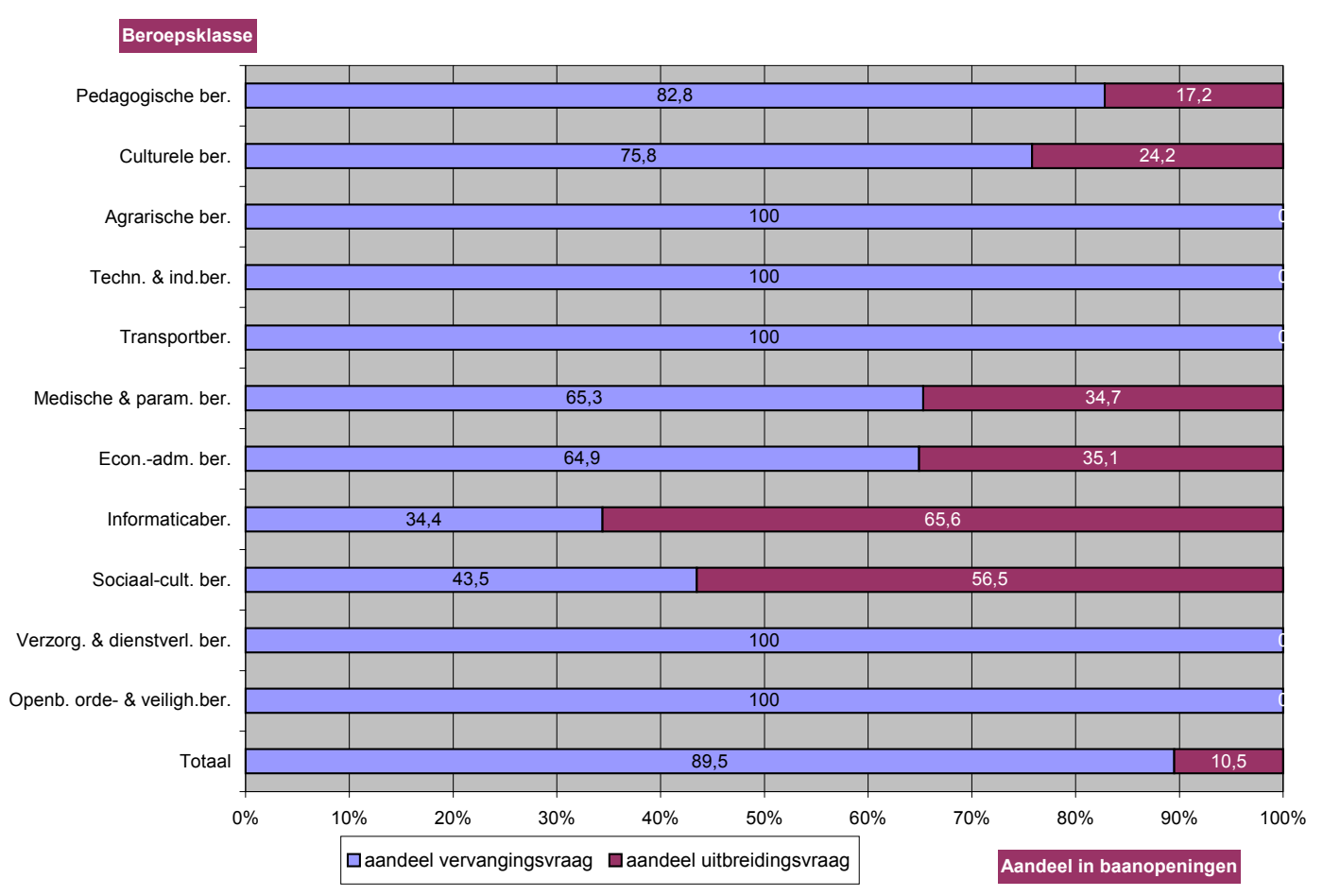

Bron: ROA

In het volgende kader staan de beroepsgroepen met de relatief hoogste en laagste totale vraag op korte en middellange termijn in Overijssel. Voor de korte termijn hebben Weg- en waterbouwkundige vakkrachten een relatief hoog percentage baanopeningen. Ook zijn er goede vooruitzichten wat betreft de vraag naar personeel op de korte termijn voor juridisch en fiscaal medewerkers.

Daar tegenover staat het relatief gering percentage baanopeningen voor apothekersassistenten en medische laboranten en commercieel employés. Deze laatste groep heeft ook op de middellange termijn last van een tekortschietende vraag naar 
personeel. Dit komt door de lage vervangingsvraag in combinatie met een geringe uitbreidingsvraag.

Op middellange termijn hebben vooral accountants, leidinggevenden, managers, en activiteitenbegeleiders en medewerkers arbeidsbemiddeling een groot percentage baanopeningen. Ook ziekenverzorgenden en, dankzij een hoge vervangingsvraag, agrarische Bedrijfshoofden en aspirant politieagenten, soldaten en beveiligingshulpen hebben relatief veel baanopeningen.

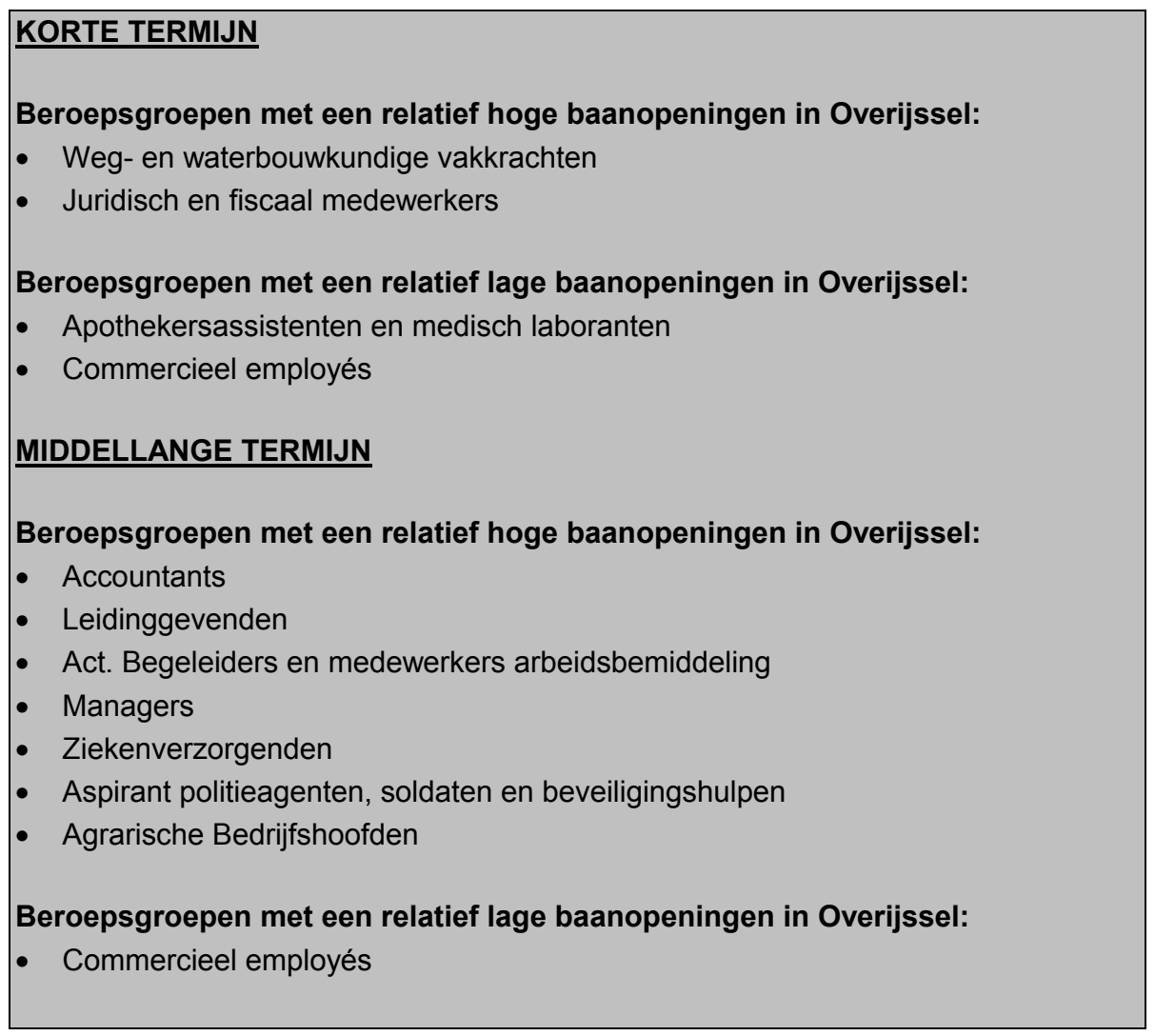

Opleidingssectoren

Ook naar opleidingssector zijn het aantal baanopeningen in Overijssel redelijk hoog. Deze is redelijk vergelijkbaar met de verwachtingen voor Nederland. In tabel 3.7 staan de verwachte baanopeningen naar opleidingssector voor Overijssel op de korte en middellange termijn weergegeven als percentage van de werkgelegenheid in het basisjaar. Op korte termijn komt de totale vraag uit op $4.6 \%$ van de werkgelegenheid in 2001, hetgeen gelijk is aan 21.250 personen. ${ }^{25}$

25. De baanopeningen naar beroepsklasse en opleidingssector worden op een verschillende manier gemeten. Dit komt mede doordat de vervangingsvraag verschilt, maar ook door een andere waarneming van de werkgelegenheidskrimp op het lage aggregatieniveau van beroepsgroepen en opleidingstypen. 
Tabel 3.7

Verwachte baanopeningen naar opleidingssector op korte en middellange termijn, Overijssel

$\begin{array}{rr}\text { Overijssel } & \text { Overijsse } \\ 2003-2004 & 2001-2006 \\ \% & \text { Jaarlijks \% }\end{array}$

$\begin{array}{lcc}\text { Basisonderwijs } & 7,7 & 7,0 \\ \text { VMBO Theorie } & 4,6 & 4,3 \\ \text { VMBO Landbouw } & 5,9 & 5,3 \\ \text { VMBO Techniek } & 5,4 & 5,0 \\ \text { VMBO Economie } & 5,7 & 5,9 \\ \text { VMBO Verzorging } & 4,9 & 4,7 \\ \text { HAVO/VWO } & 5,6 & 6,9 \\ \text { MBO Landbouw } & 3,8 & 5,5 \\ \text { MBO Techniek } & 4,5 & 4,9 \\ \text { MBO Economie } & 4,2 & 4,6 \\ \text { MBO Dienstverlening en gezondheidszorg } & 4,2 & 5,0 \\ \text { HBO Landbouw } & 3,2 & 4,4 \\ \text { HBO Techniek } & 4,5 & 4,3 \\ \text { HBO Economie } & 3,6 & 4,9 \\ \text { HBO Onderwijs en sociaal-cultureel } & 4,9 & 5,6 \\ \text { HBO Paramedisch } & 3,9 & 6,8 \\ \text { WO Landbouw } & - & - \\ \text { WO Techniek } & 3,0 & 4,1 \\ \text { WO Economie } & 2,6 & 5,6 \\ \text { WO Letteren en sociaal-cultureel } & 3,1 & 5,4 \\ \text { WO Medisch } & 3,7 & 2,8 \\ \text { Totaal } & & \\ \text { TBul } & 4,6 & 5,3\end{array}$

Bron: ROA

Tabel 3.7 laat zien dat Overijssel onder lager opgeleiden een hoger percentage baanopeningen heeft, mede als gevolg van de hogere vervangingsvraag voor deze groep. Naarmate het opleidingsniveau stijgt zijn de percentages baanopeningen vergelijkbaar met de Nederlandse situatie. Onder de universitair opgeleiden daarentegen zijn de baanopeningen duidelijk minder. Ook dit is in overstemming met het beeld dat al voor de vervangingsvraag geschetst werd. Vooral de opleidingssectoren $H B O$ Techniek en HBO Economie laten een duidelijk lager percentage baanopeningen zien. 
Figuur 3.8

Verwachte baanopeningen naar opleidingssector als percentage van de werkgelegenheid in het basisjaar, 2001-2006, Overijssel en Nederland

\section{Opleidingssector}

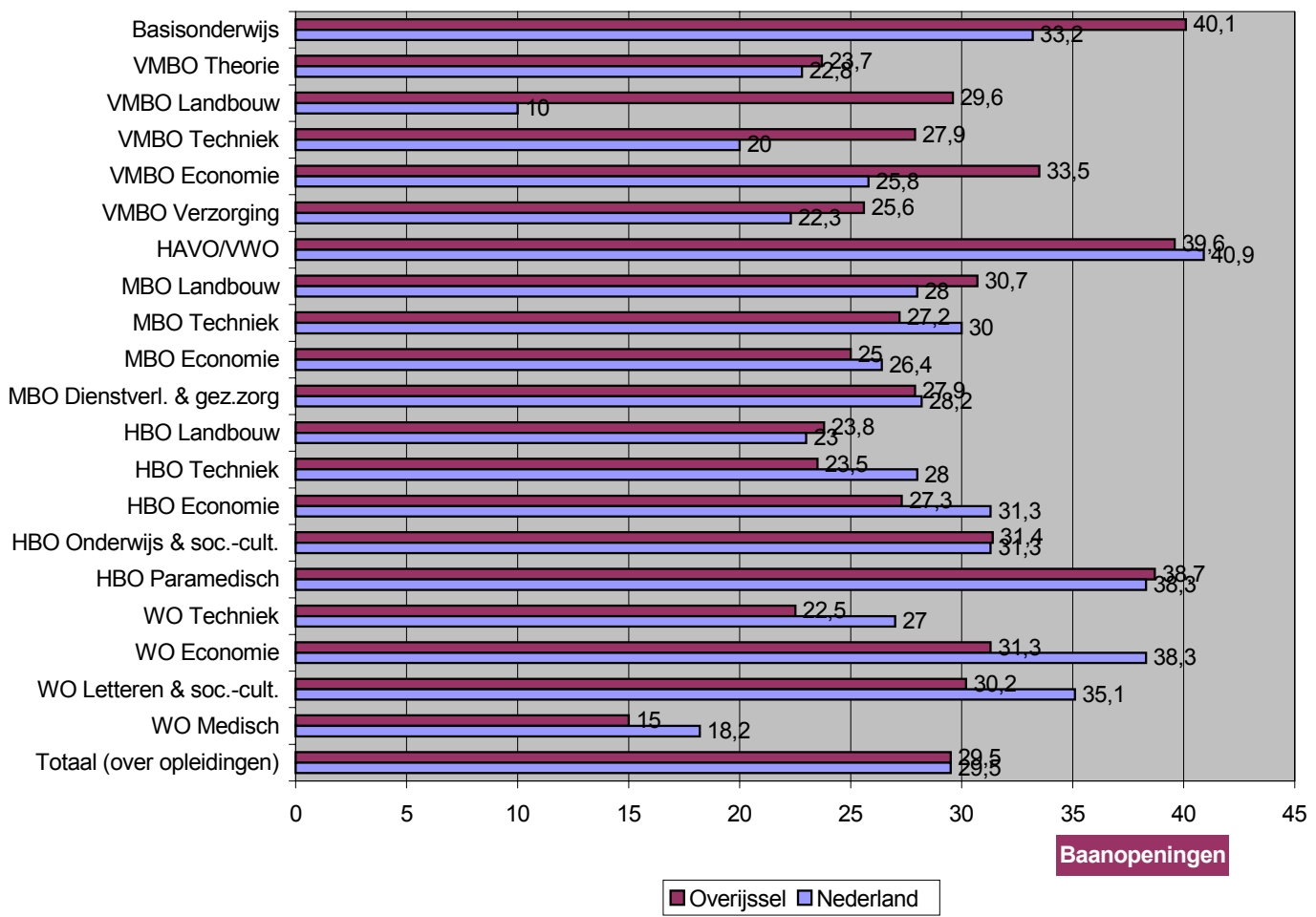

Bron: ROA

In figuur 3.9 staat het relatieve aandeel van de (positieve) uitbreidingsvraag en vervangingsvraag in de uiteindelijke baanopeningen weergegeven. Voor de meeste opleidingssectoren geldt hetzelfde als voor de totale arbeidsmarkt, namelijk dat de vervangingsvraag de voornaamste bron van de vraag naar arbeidskrachten vormt. Zoals te verwachten was, speelt voor de laagste opleidingssectoren (Basisonderwijs en $V M B O$ ) de uitbreidingsvraag op de middellange termijn geen rol voor de baanopeningen. Alleen voor de middelbaar en hoger opgeleiden draagt de uitbreidingsvraag bij aan de baanopeningen. 
Figuur 3.9

Aandeel van de uitbreidingsvraag en de vervangingsvraag in het totaal aantal baanopeningen, 2001-2006, Overijssel

\section{Opleidingssector}

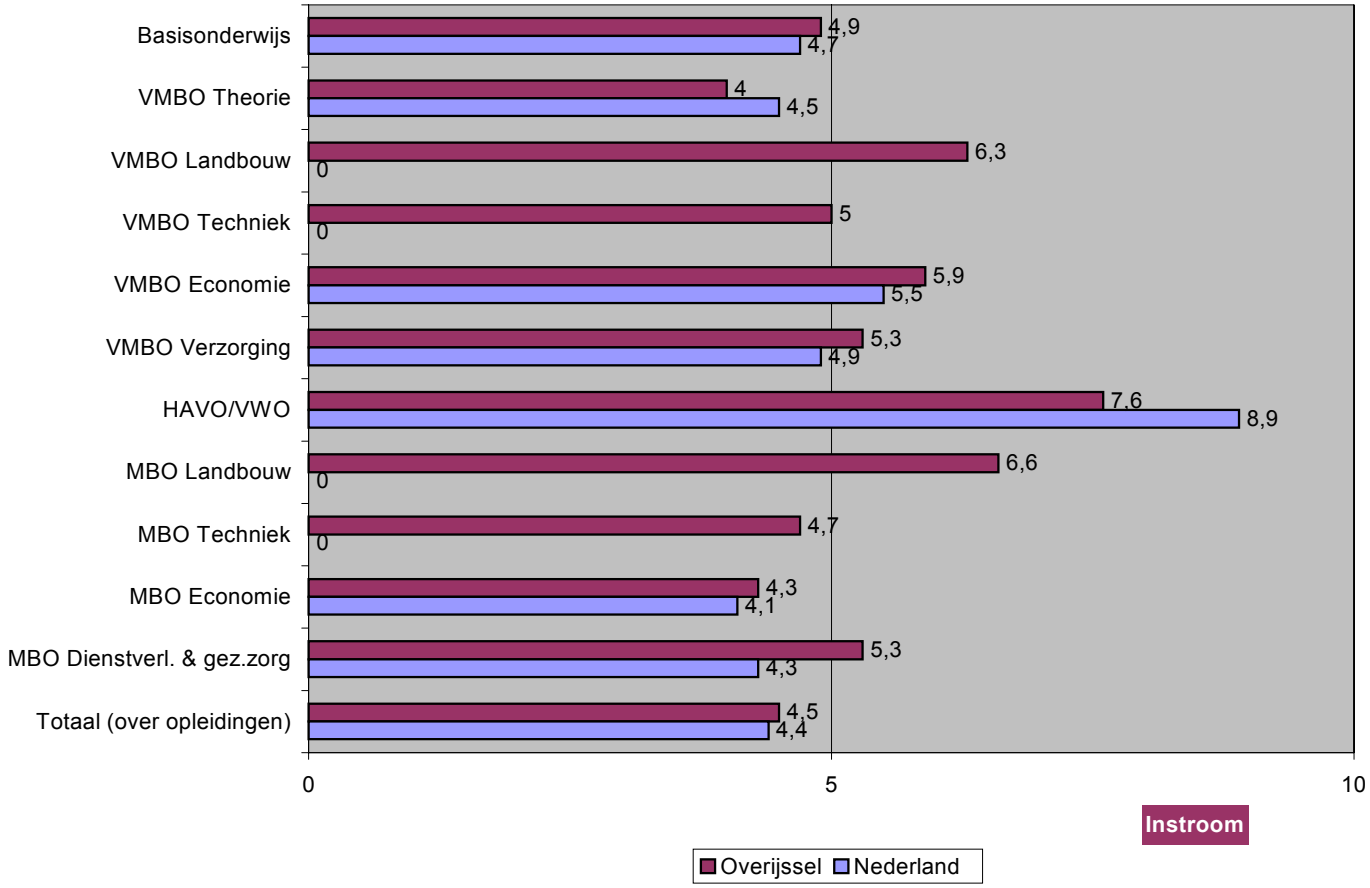

Bron: ROA

In het volgende kader zijn de opleidingstypen met relatief hoge of relatief lage percentages baanopeningen weergegeven. De verzameling van opleidingstypen in dit kader is redelijk divers. 


\section{KORTE TERMIJN}

Opleidingstypen met een relatief hoog percentage baanopeningen in Overijssel:

- Basisonderwijs

- HBO lerarenopleiding economie en maatschappij

- MBO facilitaire dienstverlening

- HBO maatschappelijk werk en hulpverlening

- HBO laboratorium

- VMBO mechanische techniek

Opleidingstypen met een relatief laag percentage baanopeningen in Overijssel:

- MBO vliegtuigtechniek

- HBO toerisme en recreatie

- $\mathrm{HBO}$ tolk en vertaler

- HBO voeding

- HBO paramedisch overig

- WO informatica en bestuurlijke informatiekunde

- WO farmacie

- WO kunstwetenschappen

\section{MIDDELLANGE TERMIJN}

Opleidingstypen met een relatief hoog percentage baanopeningen in Overijssel:

- HBO lerarenopleiding economie en maatschappij

- HBO (fysio)therapie

Opleidingstypen met een relatief laag percentage baanopeningen in Overijssel:

- WO (dier)geneeskunde

- HBO vervoer en logistiek

- HBO milieukunde en levensmiddelentechnologie 



\section{Knelpunten en perspectieven op de Overijsselse arbeidsmarkt}

Over het algemeen zijn de toekomstige arbeidsmarktperspectieven voor schoolverlaters redelijk tot goed. De arbeidsmarktperspectieven van schoolverlaters zonder een startkwalificatie voor de arbeidsmarkt (Basisonderwijs en VMBO) lijken over het algemeen beter te zijn dan voor schoolverlaters met een MBO-diploma, met name vanwege de relatief grote vervangingsvraag. Het perspectief is echter toch niet zo rooskleurig als het lijkt. De banen waarin zij instromen bieden weinig carrièreperspectief en zijn relatief vaak tijdelijk van aard of voor een beperkt aantal uren per week. Daardoor besluiten zij vaak om niet meer te participeren op de arbeidsmarkt, en ontstaat er weer vervangingsvraag naar nieuwe jonge schoolverlaters zonder diploma of met hooguit een VMBO-diploma. Degenen die wel op de arbeidsmarkt blijven volgen vaak een postinitiële opleiding op VMBO- respectievelijk MBO-niveau. Ook hierdoor ontstaat vervangingsvraag naar ongeschoolden en VMBO'ers.

Op de middellange termijn hebben vooral schoolverlaters met een opleiding binnen (V)MBO Techniek en (V)MBO Economie de beste arbeidsmarktperspectieven. De studierichting is blijkbaar meer bepalend voor het arbeidsmarktperspectief dan het opleidingsniveau. Schoolverlaters van opleidingen binnen VMBO Landbouw en MBO Landbouw kunnen daarentegen op de middellange termijn problemen verwachten bij het vinden van een baan. Hetzelfde geldt voor VMBO Verzorging en MBO Dienstverlening en verzorging. Schoolverlaters met een dergelijke opleidingsachtergrond zullen niet alleen op de korte termijn geconfronteerd worden met een ongunstige arbeidsmarktsituatie, maar ook op de middellange termijn zullen zij hiervan hinder ondervinden.

Op de korte termijn kunnen grote knelpunten in de personeelsvoorziening voor werkgevers verwacht worden in de Pedagogische beroepen, Medische en paramedische beroepen en de Sociaal-culturele beroepen. Bij de Pedagogische beroepen wordt dit veroorzaakt door de erg lage instroom van schoolverlaters vergeleken met de hoge vervangingsvraag. Voor de middellange termijn zijn er in de meeste beroepsklassen enige rekruteringsproblemen te verwachten. Bij de Pedagogische beroepen en Sociaal-culturele beroepen zijn de knelpunten het grootst. Voor de Technische en industrieberoepen, Transportberoepen en de Verzorgende en dienstverlenende beroepen hoeft men vrijwel geen knelpunten in de personeelsvoorziening te verwachten.

Overijssel heeft vooral met Gelderland en Utrecht een negatief pendelsaldo. Dit betekent dat veel mensen vanuit Overijssel naar deze provincies gaan om te werken. Vanuit de noordelijke richting is de inkomende pendel over het algemeen groter dan de uitgaande pendel. Daarentegen is er een grotere uitgaande pendel in de westelijke en zuidelijke richting dan omgekeerd. Wat betreft de pendelstromen is Gelderland veruit de belangrijkste provincie voor Overijssel. Door de uitgaande pendelstromen vanuit Overijssel naar Gelderland te verkleinen of door de inkomende pendelstromen te vergroten kunnen de knelpunten in de personeelsvoorziening voor 
Overijsselse werkgevers verminderd worden. Dit geldt met name voor de Culturele beroepen en de Agrarische beroepen, waarvoor op de middellange termijn de Overijsselse knelpunten naar verwachting groter zijn dan de Gelderse. Verder blijkt dat de pendelstromen vanuit Duitsland naar Overijssel de laatste jaren aanzienlijk zijn toegenomen. De uitgaande pendel vanuit Overijssel naar Duitsland is in lichte mate afgenomen. Binnen Overijssel is vooral Twente verantwoordelijk voor de pendel met Duitsland.

\subsection{Inleiding}

In dit hoofdstuk wordt een beeld geschetst van de aansluiting tussen onderwijs en arbeidsmarkt op zowel de korte als de middellange termijn voor schoolverlaters en werkgevers in de provincie Overijssel. Hierbij wordt een onderscheid gemaakt in de toekomstige arbeidsmarktperspectieven voor schoolverlaters en de toekomstige knelpunten in de personeelsvoorziening voor werkgevers. Voor de schoolverlaters betekent dit dat voor elke opleidingscategorie de arbeidsmarktperspectieven gepresenteerd worden en dat per opleidingscategorie nader wordt ingegaan op de meest opmerkelijke ontwikkelingen van de onderliggende opleidingstypen. ${ }^{26}$

De verwachte ontwikkelingen met betrekking tot de uitbreidingsvraag, vervangingsvraag, baanopeningen en instroom van schoolverlaters zijn al besproken in de twee voorgaande hoofdstukken. De nadruk aangaande de ontwikkelingen op de Overijsselse arbeidsmarkt zullen in dit hoofdstuk liggen bij het confronteren van de verwachte vraag- en aanbodontwikkelingen op de arbeidsmarkt. De hieruit resulterende discrepanties zullen worden weergegeven door indicatoren voor de arbeidsmarktperspectieven van schoolverlaters en indicatoren voor de knelpunten in de personeelsvoorziening voor de werkgevers. Deze indicatoren geven derhalve weer of er een vraag- of aanbodoverschot verwacht wordt.

Een vraagoverschot betekent echter niet vanzelfsprekend dat er onvervulde vacatures zullen zijn, terwijl een aanbodoverschot niet per se hoeft te leiden tot een hogere werkloosheid onder schoolverlaters. Voor de werkgevers is het van belang om tijdig een indicatie te krijgen van de knelpunten in de personeelsvoorziening die ze kunnen verwachten in de beroepen waarvoor ze personeel werven. Aan de hand van deze indicatie kunnen werkgevers bijvoorbeeld besluiten hun kwalificatievereisten bij te stellen, de werving van schoolverlaters op de arbeidsmarkt te intensiveren, het onbenutte arbeidspotentieel van niet-actieven aan te spreken, of om meer leerlingen te interesseren voor de opleidingen waarvoor zij personeelstekorten ondervinden. De substitutiemogelijkheden ${ }^{27}$ voor werkgevers geven aan in hoeverre werkgevers bij een vacature in een bepaald beroep arbeidskrachten kunnen aantrekken

26. De toekomstperspectieven van afgestudeerden van het hoger onderwijs worden hier niet weergegeven omdat voor deze groep vooral de landelijke ontwikkelingen bepalend zijn voor de arbeidsmarktpositie bij het betreden van de arbeidsmarkt. De oorzaak hiervan is gelegen in het aanbod van afgestudeerden op de arbeidsmarkt, dat door de grote geografische mobiliteit slechts in beperkte mate is toe te schrijven aan een bepaalde regio (zie ook hoofdstuk 5).

27. Zie tabel 5.13 van de Statistische Bijlage voor informatie over de substitutiemogelijkheden per beroepsgroep. 
met uiteenlopende opleidingsachtergronden. Indien werkgevers afhankelijk zijn van het arbeidsaanbod van een bepaald opleidingstype zullen de substitutiemogelijkheden beperkt zijn.

De uitwijkmogelijkheden ${ }^{28}$ voor schoolverlaters en werkzoekenden houden verband met het onderwijsbeleid en de structurele positie van opleidingen op de arbeidsmarkt. Het curriculum van opleidingen kan variëren van een smal en specialistisch vakgebied tot een brede en algemene opleidingsachtergrond. Veranderingen in het curriculum, door bijvoorbeeld een verbreding van de opleiding, leiden tot toegang tot een breder beroependomein. Tevens kunnen ontwikkelingen op de arbeidsmarkt ertoe leiden dat er behoefte is aan specifiek opgeleid personeel. Hierdoor kan het juist wenselijk zijn dat onderwijsinstellingen een meer specialistische opleiding starten.

In paragraaf 4.2 zullen de korte en de middellangetermijnperspectieven gepresenteerd worden naar opleidingssector. Vervolgens zullen in paragraaf 4.3 de toekomstige knelpunten in de personeelsvoorziening op zowel de korte als de middellange termijn besproken worden. Tot slot zal in paragraaf 4.4 een beschrijving gegeven worden van de pendelstromen binnen Nederland en met Duitsland. Aanpassingen in de pendelstromen kunnen gedeeltelijk een oplossing bieden voor discrepanties tussen vraag en aanbod op de Overijsselse arbeidsmarkt.

\subsection{De arbeidsmarktperspectieven voor schoolverlaters}

De verwachtingen voor de korte termijn naar opleiding

De Indicator Toekomstige Arbeidsmarktperspectieven (ITA) geeft een indicatie van de arbeidsmarktperspectieven voor schoolverlaters en geeft aan wat hun kansen zijn op de arbeidsmarkt. Een ITA die groter is dan één geeft een ongunstige arbeidsmarkt weer voor schoolverlaters, omdat er dan meer aanbod van arbeid is dan vraag. Met andere woorden er is een overschot aan arbeidskrachten op de arbeidsmarkt. Indien de ITA kleiner is dan één is er sprake van een gunstige arbeidsmarkt voor schoolverlaters. Het aanbod van arbeidskrachten is dan kleiner dan de vraag.

Tabel 4.1 presenteert de ITA met bijbehorende typeringen voor Overijssel op de korte termijn voor lagere en middelbare opleidingssectoren. Deze indicator geeft voor elk opleidingstype de verhouding weer tussen het arbeidsaanbod met de betreffende opleidingsachtergrond en de daar tegenoverstaande vraag. Als het arbeidsaanbod kleiner is dan de vraag - dit komt overeen met een ITA die kleiner of gelijk is aan 1,00 - wordt het arbeidsmarktperspectief als goed of zeer goed getypeerd. Schoolverlaters zullen dan relatief gemakkelijk een baan vinden in de beroepsgroep waarvoor hun opleidingsachtergrond vereist is. Voor werkgevers daarentegen zal het juist moeilijk zijn om schoolverlaters met deze opleidingsachtergrond aan te trekken. Een

28. Zie tabel 5.12 van de Statistische Bijlage voor informatie over de uitwijkmogelijkheden per opleidingstype en hoofdstuk 2 in dit rapport. 
goed arbeidsmarktperspectief voor schoolverlaters zal doorgaans samenvallen met grote knelpunten in de personeelsvoorziening voor werkgevers in de beroepsgroepen waarin deze schoolverlaters terechtkomen.

Tabel 4.1

Indicator Toekomstige Arbeidsmarktperspectieven (ITA) per opleidingssector voor de korte termijn, Overijssel, 2004

\begin{tabular}{lcl}
\hline Opleidingssector & ITA & Typering \\
\hline Basisonderwijs & 0,97 & Goed \\
VMBO Theorie & 1,00 & Goed \\
VMBO Landbouw & 1,01 & Redelijk \\
VMBO Techniek & 0,99 & Goed \\
VMBO Economie & 1,00 & Goed \\
VMBO Verzorging & 1,02 & Redelijk \\
HAVO/VWO & 1,02 & Redelijk \\
MBO Landbouw & 1,07 & Matig \\
MBO Techniek & 1,03 & Redelijk \\
MBO Economie & 1,00 & Goed \\
MBO Dienstverlening en gezondheidszorg & 1,01 & Redelijk \\
\end{tabular}

Bron: ROA

Tabel 4.1 laat zien dat voor de korte termijn de perspectieven van schoolverlaters zonder een startkwalificatie voor de arbeidsmarkt (Basisonderwijs en VMBO) over het algemeen beter zijn dan voor schoolverlaters met een MBO-diploma. Alleen voor de richting Economie zijn de arbeidsmarktperspectieven voor gediplomeerde schoolverlaters van zowel $V M B O$ als $M B O$ op de korte termijn goed. Deze relatief gunstige perspectieven voor Basisonderwijs en $V M B O$ worden veroorzaakt door de grote vervangingsvraag. De uitbreidingsvraag voor deze opleidingssectoren is negatief.

De matige arbeidsmarktperspectieven voor schoolverlaters met MBO Landbouw als opleidingsachtergrond worden met name veroorzaakt door de erg hoge arbeidsmarktinstroom van schoolverlaters. Het aantal baanopeningen is dan niet voldoende om iedereen met een dergelijke opleidingsachtergrond te voorzien van een baan in deze sector.

De verwachtingen voor de middellange termijn naar opleiding

Tabel 4.2 laat zien dat over het algemeen op de middellange termijn de arbeidsmarktperspectieven voor schoolverlaters gunstig zijn. Het is opmerkelijk dat de schoolverlaters die ongeschoold zijn en Basisonderwijs als hoogst voltooide opleiding hebben afgerond zowel op de korte termijn als op de middellange termijn een goed arbeidsmarktperspectief hebben. Het perspectief van deze voor het merendeel 'drop-outs' van het $V M B O$ is echter niet zo rooskleurig als het op grond van tabel 4.1 en tabel 4.2 lijkt. De banen waarin zij instromen bieden weinig carrièreperspectief en zijn relatief vaak van tijdelijke aard of voor een beperkt aantal 
uren per week. Mede door de eveneens relatief slechte arbeidsomstandigheden en arbeidsvoorwaarden zullen werkenden zonder diploma in het voortgezet onderwijs vaak van baan wisselen of op den duur uitstromen van de arbeidsmarkt. Doordat ongeschoolden, mede vanwege het gebrek aan loopbaanperspectief, vaak besluiten om niet meer te participeren op de arbeidsmarkt, ontstaat er weer vervangingsvraag naar nieuwe jonge ongediplomeerde schoolverlaters. Degenen die wel op de arbeidsmarkt blijven volgen relatief vaak een postinitiële opleiding. ${ }^{29}$ Ook hierdoor ontstaat vervangingsvraag naar ongeschoolden. Het bovenstaande geldt overigens ook, maar dan in mindere mate, voor schoolverlaters met een VMBO-diploma. Ook zij keren relatief vaak de arbeidsmarkt de rug toe, of trachten naderhand alsnog een MBO-diploma te halen.

Op de middellange termijn hebben vooral schoolverlaters met een opleiding binnen (V)MBO Techniek en (V)MBO Economie de beste arbeidsmarktperspectieven. De studierichting is blijkbaar meer bepalend voor het arbeidsmarktperspectief dan het opleidingsniveau. Schoolverlaters van opleidingen binnen VMBO Landbouw en MBO Landbouw kunnen daarentegen op de middellange termijn problemen verwachten bij het vinden van een baan. Hetzelfde geldt voor VMBO Verzorging en MBO Dienstverlening en verzorging. Schoolverlaters met een dergelijke opleidingsachtergrond zullen dus niet alleen op de korte termijn geconfronteerd worden met een ongunstige arbeidsmarktsituatie, maar ook op de middellange termijn zullen zij hiervan hinder ondervinden.

Tabel 4.2

Indicator Toekomstige Arbeidsmarktperspectieven (ITA) per opleidingssector voor de middellange termijn, Overijssel, 2006

\begin{tabular}{lll}
\hline Opleidingssector & ITA & Typering \\
\hline Basisonderwijs & 0,91 & Goed \\
VMBO Theorie & 0,98 & Goed \\
VMBO Landbouw & 1,05 & Redelijk \\
VMBO Techniek & 1,00 & Goed \\
VMBO Economie & 1,00 & Goed \\
VMBO Verzorging & 1,03 & Redelijk \\
HAVO/VWO & 1,03 & Redelijk \\
MBO Landbouw & 1,05 & Redelijk \\
MBO Techniek & 0,99 & Goed \\
MBO Economie & 0,99 & Goed \\
MBO Dienstverlening en gezondheidszorg & 1,01 & Redelijk \\
\end{tabular}

Bron: ROA

De middellangetermijnperspectieven voor de opleidingssectoren VMBO Landbouw en MBO Landbouw zijn - evenals de kortetermijnperspectieven - het minst gunstig, hetgeen wordt veroorzaakt door de hoge arbeidsmarktinstroom van schoolverlaters

29. Zie hoofdstuk 5 van De arbeidsmarkt naar opleiding en beroep tot 2006 (ROA, 2001). 
ten opzichte van de verwachte uitbreidings- en vervangingsvraag. Het aantal baanopeningen is dan niet voldoende voor deze schoolverlaters om een goede positie op de arbeidsmarkt te verwerven.

De keerzijde van de goede middellangetermijnperspectieven voor schoolverlaters is dat werkgevers knelpunten in de personeelsvoorziening zullen ondervinden. Dit betekent dat werkgevers bij wervingsproblemen de knelpunten in de personeelsvoorziening kunnen oplossen door de uitstroom van werknemers af te remmen. ${ }^{30}$ Met name voor ongeschoolden (Basisonderwijs) kunnen werkgevers de grote uitstroom trachten af te remmen, waardoor de knelpunten hier niet zo groot hoeven te zijn.

De opleidingen met de beste en slechtste arbeidsmarktperspectieven

De opleidingssectoren van tabel 4.1 en tabel 4.2 zijn verder te differentiëren naar de onderliggende opleidingstypen. Dit impliceert tevens dat er verschillen in arbeidsmarktperspectieven kunnen bestaan tussen de opleidingstypen binnen een bepaalde opleidingssector. In de schema's worden de opleidingstypen met de beste en de slechtste arbeidsmarktperspectieven weergegeven voor zowel de korte als de middellange termijn. In de Statistische Bijlage bij dit rapport wordt het volledige overzicht van perspectieven voor de korte en middellange termijn per opleidingstype op VMBO- en MBO-niveau gegeven.

In tabel 4.1 was te zien dat schoolverlaters met als opleidingsachtergrond VMBO Economie en $M B O$ Economie gunstige arbeidsmarktperspectieven mogen verwachten op de korte termijn. Bij opleidingscategorie MBO Economie wordt dit met name veroorzaakt door de onderliggende opleidingstypen $M B O$ geld, bank en belastingen en door MBO verzekeringswezen. Bij VMBO Economie worden echter bij één van de onderliggende opleidingstypen, namelijk VMBO administratie, handel en textiel, minder goede arbeidsmarktperspectieven verwacht op de korte termijn.

De redelijke arbeidsmarktperspectieven voor schoolverlaters van $M B O$ Techniek worden met name veroorzaakt door de onderliggende opleidingstypen $M B O$ grafische techniek en $M B O$ bouw. Andere onderliggende opleidingstypen van deze opleidingssector, zoals $M B O$ werktuigbouw en mechanische techniek en MBO fijnmechanische techniek en laboratorium, zullen daarentegen goede perspectieven bieden voor schoolverlaters.

In het volgende kader worden de opleidingstypen met de beste en slechtste arbeidsmarktperspectieven voor de middellange termijn weergegeven. Veel van deze opleidingstypen hadden ook de beste respectievelijk slechtste arbeidsmarktperspectieven voor de korte termijn. Eerder werd al aangegeven dat er matige arbeidsmarktperspectieven worden verwacht voor VMBO Landbouw en MBO Landbouw op de middellange termijn.

30. De Indicator van de Toekomstige Knelpunten in de Personeelsvoorziening (ITKP) houdt rekening met de verwachting dat bij knelpunten in de personeelsvoorziening de uitstroom van werkenden afgeremd kan worden. 


\section{KORTE TERMIJN}

Opleidingstypen met de beste arbeidsmarktperspectieven voor schoolverlaters in Overijssel in 2004:

- $\quad$ VMBO vervoer

- $\quad$ VMBO mechanische techniek

- $\quad \mathrm{MBO}$ geld, bank en belastingen

- $\quad$ MBO verzekeringswezen

- $\quad \mathrm{MBO}$ openbare orde en veiligheid

- $\quad \mathrm{MBO}$ verpleging en verzorging

Opleidingstypen met de slechtste arbeidsmarktperspectieven voor schoolverlaters in Overijssel in 2004:

- $\quad$ VMBO administratie, handel en textiel

- $\quad$ MBO grafische techniek

- $\quad$ MBO horeca

- $\quad \mathrm{MBO}$ uiterlijke verzorging

- MBO bouw

- $\quad$ MBO voeding, natuur en milieu

\section{MIDDELLANGE TERMIJN}

Opleidingstypen met de beste arbeidsmarktperspectieven voor schoolverlaters in Overijssel in 2006:

- $\quad$ VMBO vervoer

- $\quad$ VMBO mechanische techniek

- $\quad$ MBO geld, bank en belastingen

- $\quad \mathrm{MBO}$ openbare orde en veiligheid

- $\quad$ MBO procestechniek

- $\quad \mathrm{MBO}$ vervoer

Opleidingstypen met de slechtste arbeidsmarktperspectieven voor schoolverlaters in Overijssel in 2006:

- VMBO administratie, handel en textiel

- VMBO elektrotechniek

- $\quad$ VMBO landbouw en natuurlijke omgeving

- $\quad \mathrm{MBO}$ sociaal-pedagogisch en welzijn

- $\quad$ MBO uiterlijke verzorging

- MBO bouw 
Er zijn echter ook nog andere opleidingstypen waarvoor slechte arbeidsmarktperspectieven verwacht worden. Zo wordt het opleidingstype VMBO administratie, handel en textiel gekenmerkt door een gemiddeld aantal baanopeningen met een hoge instroom van schoolverlaters op de arbeidsmarkt. Hierdoor is de kans dat schoolverlaters met een dergelijke opleidingsachtergrond een goed bij hun opleiding aansluitende baan vinden relatief klein. Tevens blijkt uit tabel 4.2 dat schoolverlaters die als opleidingsachtergrond MBO Dienstverlening en gezondheidszorg hebben redelijke arbeidsmarktperspectieven kunnen verwachten op de middellange termijn.

\subsection{Knelpunten in de personeelsvoorziening voor werkgevers}

\section{De verwachtingen voor de korte termijn naar beroep}

Naast de indicator voor schoolverlaters wordt er ook een indicator voor werkgevers gegeven. De Indicator Toekomstige Knelpunten in de personeelsvoorziening naar Beroep (ITKB) geeft een indicatie van de verwachte knelpunten die werkgevers zullen ondervinden bij het aantrekken van nieuw personeel. De interpretatie van de ITKB is gelijk aan die van de ITA. Dit betekent dat een ITKB van groter dan één aangeeft dat er meer aanbod van personeel is dan dat er vraag naar personeel is. $\mathrm{Er}$ zullen dan geen knelpunten zijn bij de werving van nieuw personeel. Een ITKB die kleiner is dan één geeft aan dat de vraag naar personeel groter is dan het aanbod. De werkgevers zullen problemen ondervinden bij het aantrekken van personeel, dus er zullen knelpunten optreden op het betreffende segment van de arbeidsmarkt.

Werkgevers willen veelal weten voor welke beroepen in de toekomst de meeste baanopeningen gaan optreden om het personeelsbeleid een nadere invulling te kunnen geven. In eerste instantie zullen zij vooral knelpunten voor het vervullen van bepaalde functies ondervinden. Op deze functies kunnen vaak schoolverlaters met een uiteenlopende opleidingsachtergrond ingezet worden. De Indicator Toekomstige Knelpunten in de personeelsvoorziening naar Beroep (ITKB) houdt rekening met de verwachte schaarste op de arbeidsmarkt voor de verschillende relevante opleidingstypen per beroep. Indien er een sterke één-op-één relatie is tussen opleiding en beroep, zoals in de zorg en in het onderwijs, komt de verwachte vraag-aanbod verhouding voor deze opleidingen en beroepen grotendeels overeen.

Uit tabel 4.3 blijkt dat er op de korte termijn grote knelpunten verwacht kunnen worden in de Pedagogische beroepen, Medische en paramedische beroepen en de Sociaal-culturele beroepen. Bij de Pedagogische beroepen wordt dit veroorzaakt door de erg lage instroom van schoolverlaters vergeleken met de hoge vervangingsvraag. De rekruteringsproblematiek bij de Pedagogische beroepen is echter een landelijk fenomeen. Deze beroepsklasse bestaat met name uit docentenberoepen die op HBO- en WO-niveau functioneren. Bij de Sociaal-culturele beroepen is juist de uitbreidingsvraag hoog vergeleken met een gemiddelde instroom van schoolverlaters. Ook bij de Medische en paramedische beroepen is een gemiddelde uitbreidingsvraag hoog vergeleken met de lage instroom van schoolverlaters, waardoor werkgevers geconfronteerd zullen worden met knelpunten in de personeelsvoorziening op de korte termijn. 
Tabel 4.3

Indicator Toekomstige Knelpunten in de personeelsvoorziening naar Beroep (ITKB) per beroepsklasse voor de korte termijn, Overijssel, 2004

\begin{tabular}{lll}
\hline Beroepsklasse & ITKB & Typering \\
& & \\
\hline & & Groot \\
Pedagogische beroepen & 0,97 & Enige \\
Culturele beroepen & 1,03 & Enige \\
Agrarische beroepen & 1,02 & Enige \\
Technische en industrieberoepen & 1,03 & Enige \\
Transportberoepen & 1,04 & Groot \\
Medische en paramedische beroepen & 0,99 & Enige \\
Economisch-administratieve beroepen & 1,01 & Enige \\
Informaticaberoepen & 1,01 & Groot \\
Sociaal-culturele beroepen & 0,98 & Enige \\
Verzorgende en dienstverlenende beroepen & 1,01 & Enige \\
Openbare orde- en veiligheidberoepen & 1,05 &
\end{tabular}

\section{Bron: ROA}

Het ziet wat rooskleuriger uit voor werkgevers die vacatures open hebben staan in Openbare orde- en veiligheidberoepen en Transportberoepen. Bij de Transportberoepen kunnen werkgevers ondanks de hoge instroom van schoolverlaters enige knelpunten verwachten.

\section{De verwachtingen voor de middellange termijn naar beroep}

De problemen die werkgevers kunnen verwachten op de middellange termijn op de Overijsselse arbeidsmarkt bij het aantrekken van nieuw personeel worden weergegeven in tabel 4.4. In de meeste beroepsklassen zijn er enige rekruteringsproblemen te verwachten op de middellange termijn. Bij de Pedagogische beroepen en Sociaalculturele beroepen zijn de knelpunten het grootst. Voor de Technische en industrieberoepen, Transportberoepen en de Verzorgende en dienstverlenende beroepen hoeft men vrijwel geen knelpunten in de personeelsvoorziening te verwachten.

De knelpunten in de personeelsvoorziening bij de Pedagogische beroepen worden net als op de korte termijn veroorzaakt door een zeer lage arbeidsmarktinstroom van studenten met een pedagogische opleiding op de arbeidsmarkt. Het grote aantal baanopeningen wordt voornamelijk gegenereerd door vervangingsvraag en kan mede door de geringe substitutiemogelijkheden voor werkgevers slechts moeizaam opgevuld worden, waardoor werkgevers geconfronteerd zullen worden met knelpunten. Dit is tevens een afspiegeling van de landelijke situatie in deze beroepsklasse.

Bij de Sociaal-culturele beroepen worden de knelpunten in de personeelsvoorziening veroorzaakt door de verwachte hoge werkgelegenheidsgroei. Met name voor de activiteitenbegeleiders en de medewerkers arbeidsbemiddeling binnen deze beroepsklasse is de verwachte uitbreidingsvraag erg hoog. Een hoge toekomstige werkgelegenheidsgroei leidt tot uitbreidingsvraag en doordat de arbeidsmarktinstroom deze stijging in de werkgelegenheid niet kan bijbenen, ontstaan er knelpunten. Bij de 
Transportberoepen en Verzorgende en dienstverlenende beroepen zijn er vrijwel geen knelpunten te verwachten op de middellange termijn. Het kleine aantal baanopeningen in deze beroepsklassen zal met gemak opgevuld kunnen worden door de vrij hoge instroom van schoolverlaters.

Tabel 4.4

Indicator Toekomstige Knelpunten in de personeelsvoorziening naar Beroep (ITKB) per beroepsklasse voor de middellange termijn, Overijssel, 2006

\begin{tabular}{lll}
\hline Beroepsklasse & ITKB & Typering \\
& & \\
Pedagogische beroepen & 0,90 & Groot \\
Culturele beroepen & 1,04 & Enige \\
Agrarische beroepen & 1,05 & Enige \\
Technische en industrieberoepen & 1,10 & Vrijwel geen \\
Transportberoepen & 1,15 & Vrijwel geen \\
Medische en paramedische beroepen & 1,02 & Enige \\
Economisch-administratieve beroepen & 1,03 & Enige \\
Informaticaberoepen & 1,02 & Enige \\
Sociaal-culturele beroepen & 0,97 & Groot \\
Verzorgende en dienstverlenende beroepen & 1,13 & Vrijwel geen \\
Openbare orde- en veiligheidberoepen & 1,02 & Enige \\
& & \\
\hline
\end{tabular}

Bron: ROA

\section{De kleinste en grootste knelpunten naar beroep}

Aan de hand van de knelpunten in de personeelsvoorziening voor werkgevers bij de verschillende beroepsklassen kunnen de onderliggende beroepsgroepen bekeken worden. Onderstaand schema geeft een overzicht van de beroepsgroepen waarvoor werkgevers relatief veel dan wel weinig knelpunten in de personeelsvoorziening kunnen verwachten in Overijssel op de korte termijn.

Werkgevers die op zoek zijn naar elektromonteurs zullen geconfronteerd worden met relatief veel rekruteringsproblemen op de korte termijn. Ondanks de hoge instroom van schoolverlaters kunnen de vacatures die met name veroorzaakt worden door werkgelegenheidsgroei maar met moeite opgevuld worden. Tevens zal de beroepsgroep van procesoperators te maken krijgen met veel rekruteringsproblemen. Deze problemen worden veroorzaakt door een erg lage instroom van schoolverlaters.

Bij de beroepsgroepen waarvoor weinig rekruteringsproblemen verwacht worden op de korte termijn, worden vooral bij de productiemedewerkers en de laders en lossers de gunstige perspectieven voor werkgevers veroorzaakt door een hoge instroom van schoolverlaters vergeleken met het aantal baanopeningen. Aan de ene kant worden schoolverlaters die emplooi zoeken in één van deze beroepsgroepen geconfronteerd met weinig openstaande vacatures. Werkgevers daarentegen zullen een ruime keuze aan potentiële werknemers hebben waardoor de rekruteringsproblemen gering zijn. 


\section{KORTE TERMIJN}

Beroepsgroepen met relatief veel rekruteringsproblemen voor werkgevers in Overijssel in 2004:

- Juridisch en fiscaal medewerkers

- Procesoperators

- Confectiearbeiders

- Elektromonteurs

- Weg- en waterbouwkundige vakkrachten

Beroepsgroepen met relatief weinig rekruteringsproblemen voor werkgevers in Overijssel in 2004:

- Productiemedewerkers

- Bouwvakkers

- Receptionisten

- Verkopers

- Laders en lossers

\section{MIDDELLANGE TERMIJN}

Beroepsgroepen met relatief veel rekruteringsproblemen voor werkgevers in Overijssel in 2006:

- Ziekenverzorgenden

- Juridisch en fiscaal medewerkers

- Productieplanners

- Procesoperators

- Activiteiten begeleiders en medewerkers arbeidsbemiddeling

Beroepsgroepen met relatief weinig rekruteringsproblemen voor werkgevers in Overijssel in 2006:

- Monteurs

- Productiemedewerkers

- Agrarische arbeiders

- Verzekeringsagenten

- Receptionisten

- Hulpkrachten horeca en verzorging

De beroepsgroepen waarvoor relatief veel rekruteringsproblemen verwacht worden op de middellange termijn worden voornamelijk gekenmerkt door een hoge verwachte werkgelegenheidsgroei. Dit houdt in dat het aantal baanopeningen voornamelijk veroorzaakt wordt door de uitbreidingsvraag. De rekruteringsproblemen voor werkgevers ontstaan dan doordat er te weinig schoolverlaters beschikbaar zijn om deze baanopeningen te vervullen. Een uitzondering hierop zijn de juridisch en fiscaal medewerkers. De rekruteringsproblemen in deze beroepsgroep worden veroorzaakt door een erg hoge vervangingsvraag. De lage instroom van schoolverlaters in deze beroepsgroep kan niet aan de vervangingsvraag voldoen. Tevens 
zullen werkgevers die op zoek zijn naar ziekenverzorgenden geconfronteerd worden met rekruteringsproblemen. De instroom van schoolverlaters kan de erg hoge werkgelegenheidsgroei niet bijbenen.

Bij de beroepsgroepen waarvoor weinig rekruteringsproblemen verwacht worden op de middellange termijn worden de agrarische arbeiders en de receptionisten gekenmerkt door een (zeer) lage uitbreidingsvraag. Dus werkgevers die dergelijke arbeidskrachten goed kunnen gebruiken hoeven geen rekruteringsproblemen te verwachten op de middellange termijn, aangezien het aanbod van arbeidskrachten voor deze beroepsgroepen groter is dan de vraag. Werkgevers die op zoek zijn naar bibliotheekassistenten, productiemedewerkers of (elektro)monteurs zullen op de middellange termijn te maken krijgen met een gemiddeld aantal baanopeningen. De geringe rekruteringsproblemen in deze beroepsgroepen worden met name veroorzaakt door de (zeer) hoge arbeidsmarktinstroom van schoolverlaters. Werkgevers die op zoek zijn naar productiemedewerkers kunnen dus zowel op de korte als op de middellange termijn problemen verwachten bij het aantrekken van personeel voor deze beroepsgroep.

\subsection{Pendel als aanpassingsproces op de arbeidsmarkt}

$\mathrm{Bij}$ het zoeken naar een baan moeten werkzoekenden verschillende afwegingen maken. De baanzoekduur wordt daarbij beïnvloed door de vraag-aanbod verhoudingen, maar ook door kennis en vaardigheden van de werkzoekenden en de eisen die gesteld worden aan de nieuwe functie, de werkgever en de arbeidsvoorwaarden. Daarbij speelt ook de geografische mobiliteit van de werkzoekende, dat wil zeggen de bereidheid om te verhuizen of te pendelen, een belangrijke rol. De daadwerkelijke pendelstromen zullen echter beperkt worden door de daaraan verbonden kosten. Individuen moeten ten gevolge van pendel kosten maken voor het overbruggen van een bepaalde reisafstand. Bovendien zou de reistijd kunnen worden gerekend tot de uren die meer besteed worden aan het werk, waardoor het feitelijk netto uurloon lager uitvalt. Daarnaast zou het vinden van een baan die verder van de woonplaats gelegen is, hogere zoekkosten met zich mee kunnen brengen. Deze zijn te beschouwen als een eenmalige investering om de kans op het vinden van een baan te vergroten.

Over het algemeen zijn werkenden die bereid zijn verder te reizen voor hun werk dan naar hun woongemeente of naar de omliggende gemeentes hoger opgeleid en verdienen ze meer dan de mensen die werken in dezelfde gemeente als waar ze wonen. Bovendien blijkt dat vrouwen relatief minder pendelen dan mannen, vooral wanneer ze kinderen hebben. Vooral de 30'ers en de 40'ers hebben een grotere bereidheid om te reizen vergeleken met zowel jongere als oudere werkenden. De Overijsselse pendelaars overbruggen gemiddeld iets kleinere afstanden dan de landelijke pendelaars waardoor ook hun reistijd gemiddeld iets korter is. Waarschijnlijk hangt dit voor een deel samen met het iets lagere gemiddelde opleidingsniveau van de Overijsselse pendelaars vergeleken met de landelijke pendelaars. 
Mensen maken een keuze uit een groot aanbod van verplaatsingsmogelijkheden om van hun woonlocatie op hun werk te komen. Op deze manier zorgt een toename in de mobiliteit voor een betere aanpassing van vraag en aanbod op regionale arbeidsmarkten. Naast deze positieve effecten heeft mobiliteit ook negatieve effecten op de leefomgeving. ${ }^{31}$ De veranderingen die plaatsvinden ten gevolge van toenemende mobiliteit hebben namelijk direct invloed op de ruimtelijke kwaliteit van regio's. Hierbij kan men denken aan congestie en het verloren gaan van natuurgebieden door het aanleggen van infrastructuur.

Aan de hand van gegevens uit het Onderzoek Verplaatsingsgedrag 2001 (OVG) van het CBS kunnen de pendelstromen tussen Overijssel en de andere provincies nader onderzocht worden. Tabel 4.5 geeft een overzicht van deze pendelstromen. Hieruit blijkt dat de grootste pendelstromen van Overijssel plaatsvinden met de provincies Gelderland, Drenthe en Utrecht. Vooral de pendelstromen met Gelderland zijn relatief groot. Het pendelsaldo is positief indien de inkomende pendel groter is dan de uitgaande pendel.

Tabel 4.5

Inkomende en uitgaande pendelstromen voor de provincie Overijssel als percentage van de werkende beroepsbevolking van Overijssel, 2001

\begin{tabular}{lccc}
\hline Provincies & $\begin{array}{c}\text { Inkomende } \\
\%\end{array}$ & $\begin{array}{c}\text { Uitgaande pendel } \\
\%\end{array}$ & Pendelsaldo \\
\hline Groningen & 0,5 & 0,2 & + \\
Friesland & 0,6 & 0,3 & + \\
Drenthe & 1,7 & 1,1 & + \\
Gelderland & 3,7 & 4,4 & 0 \\
Flevoland & 0,6 & 0,6 & - \\
Utrecht & 0,1 & 1,4 & - \\
Noord-Holland & 0,2 & 0,7 & - \\
Zuid-Holland & 0,2 & 0,4 & - \\
Zeeland & 0,0 & 0,1 & - \\
Noord-Brabant & 0,2 & 0,3 & - \\
Limburg & 0,0 & 0,1 & - \\
Totaal & & & \\
& 7,8 & 9,6 & \\
\hline
\end{tabular}

Bron: CBS(OVG)

De provincie Overijssel heeft vooral met de provincies Gelderland en Utrecht een negatief pendelsaldo. Dit betekent dat veel mensen vanuit de provincie Overijssel naar deze provincies gaan om te werken. In de aanliggende provincies vanuit de noordelijke richting is de inkomende pendel over het algemeen groter dan de uitgaande pendel. Er gaan dus meer mensen vanuit Groningen, Friesland en Drenthe in Overijssel werken dan omgekeerd. Daarentegen is er een grotere uitgaande pendel in de westelijke richting dan omgekeerd. Dit betekent dat mensen die in Overijssel wonen de neiging hebben naar het westen te gaan om te werken, zoals Utrecht, Noord-Holland en Zuid-Holland.

31. Ministerie van Volksgezondheid, Welzijn en Sport (2000), Nationaal Verkeers- en Vervoersplan (NVVP), Den Haag. 
Het is niet alleen van belang de pendelstromen tussen de provincies te onderscheiden maar ook binnen de provincie Overijssel. Op basis van deze pendelstromen kan men de werkgelegenheidscentra binnen de provincie Overijssel onderscheiden. Deze regio's worden dan gekenmerkt door veel inkomende pendel en kunnen daardoor gezien worden als een aantrekkelijke regionale arbeidsmarkt. Regio's daarentegen die gekenmerkt worden door veel uitgaande pendel bieden blijkbaar relatief minder werkgelegenheid.

Tabel 4.6

Verdeling van Overijsselse inkomende en uitgaande pendelstromen naar gemeente, 2001

\begin{tabular}{lccc}
\hline Gemeenten & $\begin{array}{c}\text { Inkomende pendel } \\
\%\end{array}$ & $\begin{array}{c}\text { Uitgaande pendel } \\
\%\end{array}$ & Pendelsaldo \\
& & 5,8 & \\
Almelo & 9,2 & 8,8 & + \\
Deventer & 8,1 & 7,9 & + \\
Enschede & 13,4 & 8,5 & + \\
Hengelo & 9,8 & 8,7 & + \\
Zwolle & 20,8 & 5,0 & - \\
Kampen & 2,6 & 4,2 & - \\
Hardenberg & 3,0 & 4,3 & - \\
Hellendoorn & 2,0 & 4,3 & - \\
Vriezenveen & 2,1 & 42,5 & \\
Overige & 29,0 & 100 & \\
Totaal & 100 & & \\
\end{tabular}

Bron: CBS(OVG)

In tabel 4.6 staan de gemeenten vermeld met de hoogste inkomende en uitgaande pendelstromen. Deze gemeenten hebben blijkbaar een grote aantrekkingskracht op werknemers en veel arbeidsplaatsen. ${ }^{32}$ Vooral Zwolle en Enschede trekken veel werkenden uit andere gemeenten aan.

In het kader van dit hoofdstuk is het interessant om de arbeidsmarktperspectieven voor de nieuwkomers en de knelpunten in de personeelsvoorziening voor de werkgevers in verband te brengen met de pendelstromen. Voor de middellange termijn geldt namelijk dat bij de Pedagogische beroepen en de Sociaal-culturele beroepen de knelpunten in de personeelsvoorziening het grootst zijn. Voor de Technische en industrieberoepen, de Transportberoepen, de Verzorgende en dienstverlenende beroepen hoeft men vrijwel geen knelpunten te verwachten. Aanpassingen van de pendelstromen geven de mogelijkheid deze knelpunten te reduceren. Derhalve zal deze paragraaf nader worden ingegaan op de pendel met Gelderland. Zoals opgemerkt heeft Overijssel een negatief pendelsaldo met Gelderland, hetgeen betekent dat er meer inwoners van Overijssel in Gelderland werken dan omgekeerd.

Tabel 4.7 laat de pendelstromen tussen Overijssel en Gelderland zien. Hieruit blijkt dat de pendel tussen Overijssel en Gelderland verreweg het grootst is voor de Technische en industrieberoepen en de Economisch-administratieve beroepen. Met

32. Hoofdstuk 5 van dit rapport zal verder ingaan op de aantrekkingskracht van gemeenten. 66 
name voor de laatste beroepsklasse biedt Overijssel relatief veel werkgelegenheid voor de inwoners van Gelderland. ${ }^{33}$

\section{Tabel 4.7}

Pendelstromen tussen Overijssel en Gelderland uitgesplitst naar beroepsklasse, in procenten van het totaal, gemiddelde $2000-2001$

\begin{tabular}{lcc}
\hline Beroepsklasse & $\begin{array}{c}\text { Werkenden vanuit } \\
\text { Gelderland naar } \\
\text { Overijssel } \\
\%\end{array}$ & $\begin{array}{c}\text { Werkenden vanuit } \\
\text { Overijssel naar } \\
\text { Gelderland } \\
\%\end{array}$ \\
\hline Pedagogische beroepen & 9 & 8 \\
Culturele beroepen & 0 & 0 \\
Agrarische beroepen & 1 & 1 \\
Technische en industrieberoepen & 20 & 22 \\
Transportberoepen & 6 & 3 \\
Medische en paramedische beroepen & 6 & 5 \\
Economisch-administratieve beroepen & 37 & 28 \\
Informaticaberoepen & 3 & 7 \\
Sociaal-culturele beroepen & 5 & 7 \\
Verzorgende en dienstverlenende beroepen & 9 & 4 \\
Openbare orde- en veiligheidberoepen & 1 & 3 \\
Overige beroepen & 3 & 100 \\
Totaal & 100 & \\
\hline Bon: CBS(EBB) & & 4 \\
\hline
\end{tabular}

Bron: CBS(EBB)

Aangezien aanpassingen van de pendelstromen de regionale discrepanties tussen vraag en aanbod van arbeid kunnen verlichten is het interessant de knelpunten in de personeelsvoorziening voor werkgevers voor zowel Overijssel als Gelderland in kaart te brengen. Tabel 4.8 laat zien dat de toekomstige knelpunten in de personeelsvoorziening voor werkgevers op de middellange termijn in Overijssel voor vier beroepsklassen kleiner zijn vergeleken met de Gelderse knelpunten in de personeelsvoorziening. Dit geldt voor de Technische en industrieberoepen, de Transportberoepen, de Economisch-administratieve beroepen en de Informaticaberoepen. Voor deze beroepsklassen zou derhalve een grotere pendelstroom tussen Overijssel en Gelderland, bijvoorbeeld door een betere infrastructuur, weliswaar de knelpunten in de personeelsvoorziening op de Gelderse arbeidsmarkt kunnen verkleinen, maar daartegen deze knelpunten op de Overijsselse arbeidsmarkt kunnen doen toenemen. De keerzijde hiervan is dat Overijsselse schoolverlaters die in deze beroepen werkzaam willen zijn, juist hun arbeidsmarktpositie kunnen verbeteren door een baan te zoeken op de Gelderse arbeidsmarkt. Voor de meeste beroepsklassen geldt echter dat de Overijsselse knelpunten grotendeels overeenkomen met de Gelderse knelpunten voor werkgevers. Alleen voor de Culturele beroepen en de Agrarische beroepen zijn de Overijsselse knelpunten groter dan de Gelderse.

33. In combinatie met tabel 4.5 moet opgemerkt worden dat de pendelstroom van Gelderland naar Overijssel kleiner is (3,7\% van de werkende beroepsbevolking van Overijssel) dan de pendelstroom vanuit Overijssel naar Gelderland $(4,4 \%$ van de werkende beroepsbevolking van Overijssel). 
Door de uitgaande pendelstromen vanuit Overijssel naar Gelderland te verkleinen of door de inkomende pendelstromen te vergroten kunnen de knelpunten in de personeelsvoorziening voor Overijssel in deze beroepsklassen verminderd worden.

Tabel 4.8

Gewenste verandering in de pendelstroom met Gelderland op basis van de Indicator Toekomstige Knelpunten in de personeelsvoorziening naar Beroep (ITKB) per beroepsklasse voor Overijssel en Gelderland in 2006

\begin{tabular}{|c|c|c|c|}
\hline \multirow[t]{2}{*}{ Beroepsklasse } & \multicolumn{2}{|c|}{$\begin{array}{l}\text { Typering knelpunten voor } \\
\text { werkgevers }\end{array}$} & \multirow{2}{*}{$\begin{array}{l}\text { Gewenste verandering voor de } \\
\text { provincie Overijssel }\end{array}$} \\
\hline & Overijssel & Gelderland & \\
\hline Pedagogische beroepen & Groot & Groot & Geen \\
\hline Culturele beroepen & Enige & Vrijwel geen & $\begin{array}{l}\text { Afname uitgaande pendel } \\
\text { Toename inkomende pendel }\end{array}$ \\
\hline Agrarische beroepen & Enige & Vrijwel geen & $\begin{array}{l}\text { Afname uitgaande pendel } \\
\text { Toename inkomende pendel }\end{array}$ \\
\hline $\begin{array}{l}\text { Technische en } \\
\text { industrieberoepen }\end{array}$ & Vrijwel geen & Enige & $\begin{array}{l}\text { Toename uitgaande pendel } \\
\text { Afname inkomende pendel }\end{array}$ \\
\hline Transportberoepen & Vrijwel geen & Enige & $\begin{array}{l}\text { Toename uitgaande pendel } \\
\text { Afname inkomende pendel }\end{array}$ \\
\hline $\begin{array}{l}\text { Medische en } \\
\text { paramedische beroepen }\end{array}$ & Enige & Enige & Geen \\
\hline $\begin{array}{l}\text { Economisch- } \\
\text { administratieve beroepen }\end{array}$ & Enige & Groot & $\begin{array}{l}\text { Toename uitgaande pendel } \\
\text { Afname inkomende pendel }\end{array}$ \\
\hline Informaticaberoepen & Enige & Groot & $\begin{array}{l}\text { Toename uitgaande pendel } \\
\text { Afname inkomende pendel }\end{array}$ \\
\hline Sociaal-culturele beroepen & Groot & Groot & Geen \\
\hline $\begin{array}{l}\text { Verzorgende en } \\
\text { dienstverlenende } \\
\text { beroepen }\end{array}$ & Vrijwel geen & Vrijwel geen & Geen \\
\hline $\begin{array}{l}\text { Openbare orde- en } \\
\text { veiligheidberoepen }\end{array}$ & Enige & Enige & Geen \\
\hline
\end{tabular}

Bron: ROA

\subsection{Pendelstromen tussen Overijssel en Duitsland}

Naast het stimuleren van de binnenlandse pendelstromen kan de grenspendel met Duitsland ook zorgen voor een verkleining van de mismatch tussen vraag en aanbod op specifieke segmenten van de Overijsselse arbeidsmarkt. De toekomstige knelpunten in de personeelsvoorziening voor Overijsselse werkgevers zoals beschreven in de vorige paragraaf kunnen verminderd worden door het stimuleren van Duitse arbeidskrachten om zich op de Nederlandse arbeidsmarkt aan te bieden. Voor Overijsselse schoolverlaters zouden op specifieke segmenten van de Duitse arbeidsmarkt wellicht betere perspectieven dan in Nederland kunnen gelden. Op het gebied van taal, cultuur, sociale zekerheid en belastingen bestaan echter nog altijd een aantal barrières tussen de twee landen waardoor een daadwerkelijke toename van het grensoverschrijdende woon-werkverkeer of migratie niet vanzelfsprekend is. Aanpassingen in de pendelstromen tussen Overijssel en Duitsland kunnen een reductie in de mismatch op de regionale arbeidsmarkt in Overijssel bewerkstelligen. 
Opvallend is dat aanmerkelijk meer mensen vanuit Nederland naar Duitsland pendelen om te werken dan omgekeerd. ${ }^{34}$ Uit figuur 4.1 blijkt dat ook voor de provincie Overijssel geldt dat meer mensen naar Duitsland pendelen voor hun werk dan omgekeerd. Vooral het COROP-gebied Twente, dat direct aan Duitsland grenst, speelt hierbij een belangrijke rol. Blijkbaar bestaan er belemmeringen die de grenspendel vanuit Duitsland naar Nederland op een laag peil houden. Mede door de ruime beschikbaarheid van informatie en het ontbreken van taal- en cultuurverschillen kan verklaard worden waarom er eerder mobiliteit optreedt op grote afstand binnen een land dan op geringe afstand tussen landen. Bovendien wachten werkzoekenden liever in eigen land op een betere economische situatie dan dat ze werken zoeken in het buitenland, dit wordt ook wel een positieve "option value of waiting" ${ }^{35}$ genoemd.

\section{Figuur 4.1}

De omvang van de grenspendel tussen Overijssel en Duitsland in de periode van 1999 tot 2001

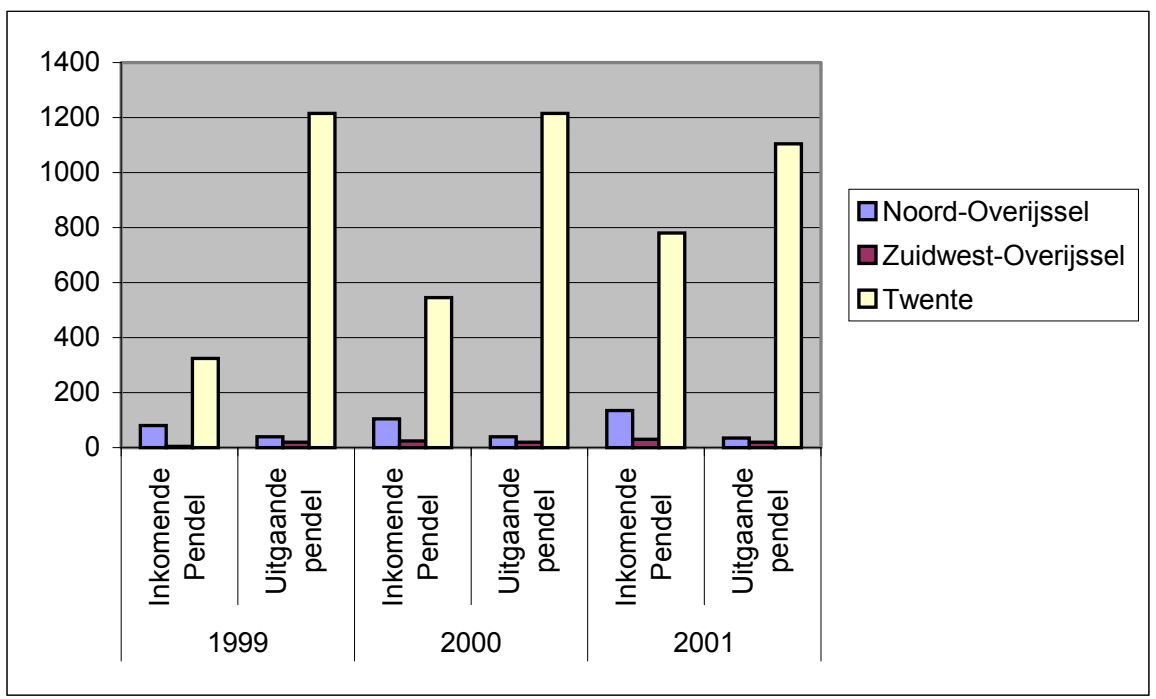

Bron: CBS(Statistiek Grensarbeid)

Toch laat figuur 4.1 ook zien dat de pendelstromen vanuit Duitsland naar Overijssel aanzienlijk zijn toegenomen. De uitgaande pendel vanuit Overijssel is in lichte mate afgenomen.

34. J. van Cruchten en R. Kuijpers, (2002), Grensarbeid tussen Nederland en België of Duitsland, Sociaal-Economische Maandstatistiek, CBS, No. 2002/4.

35. Zie T. Straubhaar en A. Wolter (1997), Globalisation, internal labour markets and the migration of the highly skilled, Intereconomics, Vol. 32, blz. 174-180. 
Beide ontwikkelingen komen overeen met de landelijke trend voor de pendelstromen tussen Nederland en Duitsland vanaf $1995 .{ }^{36}$ Een stijgende inkomende pendel en een dalende uitgaande pendel zou erop kunnen wijzen dat de bovengenoemde barrières kleiner zijn geworden en dat Nederland een steeds aantrekkelijkere arbeidsmarkt is geworden voor de Duitse beroepsbevolking, met name vanwege de sterk toegenomen krapte op de Nederlandse arbeidsmarkt gedurende de laatste jaren. De pendelstromen lijken dus inderdaad te reageren op verschillen in internationale schaarsteverhoudingen op de arbeidsmarkt. Voor 2002 is de uitgaande pendel vanuit Nederland naar Duitsland zelfs bijna even groot als de inkomende pendel vanuit Duitsland naar Nederland.

Voor de provincie Overijssel geldt dat ruim $9 \%$ van de mensen die vanuit Nederland vertrekken om in Duitsland te gaan werken afkomstig zijn uit deze provincie. Echter, bijna $12 \%$ van alle mensen die vanuit Duitsland naar Nederland pendelen, doen dit in de provincie Overijssel. Dit betekent dat Overijssel een relatief aantrekkelijke arbeidsmarkt is voor inwoners van Duitsland.

36. Zie MKW (2001), Scientific Report on the Mobility of Cross-border Workers within the EEA, Final Report, European Commission and DG Employment and Social Affairs, Germany voor een nadere analyse van de pendel tussen grensregio's van verschillende landen binnen Europa. Verder moet opgemerkt worden dat de gegevens van het CBS gebaseerd zijn op de registratie van ziekenfondsverzekerden in Duitsland en Nederland. Dit betekent dat pendelaars met een inkomen boven de ziekenfondsgrens (die overigens in Duitsland hoger ligt dan in Nederland) niet worden waargenomen. Dit leidt tot een onderschatting van het aantal pendelaars. 


\section{Overijssel in geografisch perspectief}

Werkgelegenheidsontwikkelingen in verschillende regio's in Nederland kunnen niet los van elkaar worden gezien. Het blijkt dat met name de werkgelegenheid voor hoger opgeleiden een sterke neiging heeft tot geografische clustering. De consequentie hiervan is dat steeds meer hoger opgeleiden in de Randstad gaan werken. De neiging van bedrijven om zich in elkaars buurt te vestigen duidt erop dat de spillover-effecten tussen bedrijven productiviteitsverhogend zijn. Er zijn redenen om aan te nemen dat zowel de gebieden met een sterke werkgelegenheidsconcentratie als de gebieden waar de werkgelegenheid zich juist minder concentreert baat kunnen hebben bij overheidsinterventie gericht op het stimuleren van innovatieve bedrijvigheid in werkgelegenheidskernen buiten de Randstad. In de grote agglomeraties kan hierdoor de congestie verminderen, terwijl de regionale kernen waarschijnlijk meer profijt hebben van de spill-over-effecten van nieuwe innovatieve bedrijven dan de Randstad nadeel zal ondervinden van het verdwijnen ervan.

Het clusterproces van bedrijven hoeft dus niet tot een optimale oplossing te leiden. Bedrijven zullen bij hun afweging welke locatie ze kiezen niet alle maatschappelijke consequenties meenemen. Het vestigen van specifieke bedrijven kan vervolgens gestimuleerd worden door bijvoorbeeld extra investeringen te doen in de infrastructuur. De infrastructuur en met name de bereikbaarheid van bepaalde regio's zijn belangrijke elementen bij de vestigingskeuze van bedrijven. Bedrijven willen graag goed bereikbaar zijn voor zowel hun leveranciers en klanten als hun medewerkers. Doordat specifieke bedrijven zich in een regio gaan vestigen, wordt ook de arbeidsmarkt gekenmerkt door specifieke werkgelegenheid.

In dit hoofdstuk geven we een beeld van deze geografische component van de werkgelegenheid en de effecten die hiermee gepaard gaan. Naast de bereikbaarheid van de bedrijven in logistieke zin is het van belang dat de bedrijven ook toegang hebben tot de kennisinfrastructuur van universiteiten en hogescholen. We laten zien dat een omvangrijke stroom van afgestudeerden met een hogere opleiding naar de Randstad verhuist om daar een geschikte baan te vinden. In Overijssel vormen echter ook Zwolle en Twente een regionaal werkgelegenheidscentrum. Veel meer mensen uit de omgeving komen naar deze plaatsen om te werken dan dat er inwoners uit deze kernen elders werken. De productiviteit en de lonen in deze gebieden zijn hoger, waardoor deze plaatsen een aantrekkingskracht uitoefenen op bedrijven en werkenden. Het gevolg is dat ook de bevolkingsdichtheid en de gronden huizenprijzen hoger zijn. Mensen met een hoog inkomen zijn eerder geneigd verder van hun werk te gaan wonen. De kosten van het pendelen zijn voor hen relatief laag vergeleken met de aantrekkelijkheid van met name grotere woningen buiten de stad. Het gevolg is dat juist in die gebieden waar de grootste werkgelegenheidsconcentraties te vinden zijn, relatief de meeste werklozen en mensen met een laag inkomen wonen.

Ook het pendelgedrag geeft de magnetische werking van de Randstad weer. Gemiddeld werken de bewoners van Overijssel ten Westen van hun woonplaats. Er 
is niet veel rechtstreekse pendel tussen Overijssel en de Randstad, maar de werkenden uit Overijssel worden aangezogen door de werkgelegenheid die in Gelderland ontstaat doordat mensen van daar werken in de Randstad.

\subsection{Inleiding}

In de voorgaande hoofdstukken is een beeld gegeven van de ontwikkelingen in vraag en aanbod voor verschillende groepen arbeid op de korte en middellange termijn in de provincie Overijssel. Op grond hiervan is een beeld ontstaan over de discrepanties tussen vraag en aanbod die de komende tijd in de provincie te verwachten zijn. Omdat de afstanden in Nederland betrekkelijk klein zijn, kunnen vraag- en aanbodontwikkelingen in de provincie Overijssel niet los gezien worden van de ontwikkelingen die zich op landelijk niveau afspelen. Voor een aanzienlijk deel weerspiegelen de ontwikkelingen op de arbeidsmarkt in Overijssel de landelijke trends. Er zijn echter ook opmerkelijke verschillen. Deels zijn deze verschillen te verklaren door typische kenmerken van de werkgelegenheidsstructuur van de provincie en van de demografische opbouw van de bevolking. Daarnaast speelt echter - zeker ook op de wat langere termijn - de geografische positie van de provincie een belangrijke rol bij de werkgelegenheidsontwikkelingen.

Hoewel de meeste bedrijven niet van de ene op de andere dag van locatie zullen veranderen, zullen veel bedrijven bij de keuze van hun vestigingsplaats een strategische afweging van kosten en baten maken. Met name innovatieve bedrijven die vaak een relatief hoog percentage hoger opgeleiden in dienst hebben - hebben hierbij een sterke neiging tot clusteren. Er zijn aanwijzingen dat door de recente ontwikkelingen op het gebied van ICT deze neiging tot geografische clustering nog verder is toegenomen, waardoor de innovatieve bedrijven steeds meer in enkele agglomeraties bij elkaar komen te zitten. Omdat ook werknemers op de langere termijn niet gebonden zijn aan een bepaalde stad, zal hun woonplaats afhangen van de vraag waar interessante werkgelegenheid zit. Dit betekent ook dat de verdeling van de bevolking over het land zich aan zal passen aan deze ontwikkelingen.

Hoewel er kennelijk grote voordelen verbonden zijn aan het concentreren van bedrijven is het probleem dat dit clusterproces niet vanzelfsprekend tot een optimale uitkomst hoeft te leiden. Bedrijven zullen bij hun afweging welke locatie ze kiezen immers niet alle maatschappelijke consequenties betrekken, maar met name hun eigen belang voorop stellen. Een specifiek bedrijf zal er daarom wel rekening mee houden dat het baat kan hebben van de aanwezigheid van andere bedrijven, maar houdt er geen rekening mee dat haar vestigingsbeslissing weer positieve en negatieve consequenties voor anderen kan hebben. Maatschappelijke effecten die niet worden meegewogen in de individuele keuzes van bedrijven of personen worden externaliteiten genoemd. Het is precies om deze reden dat de overheid er belang bij heeft om niet alleen de ontwikkelingen op de arbeidsmarkt te monitoren om zo discrepanties tussen vraag en aanbod te kunnen verkleinen, maar om ook actief beleid te voeren om de clustering van bedrijven te beïnvloeden. Op deze wijze kan de overheid bewerkstelligen dat de positieven externaliteiten worden vergroot en de negatieve worden tegengegaan. 
In dit hoofdstuk schetsen we een beeld van Overijssel in het licht van de Nederlandse geografische structuur. Hierbij wordt ingegaan op de drijfveren van bedrijven om bij elkaar te gaan zitten en de gevolgen van dit gedrag van bedrijven voor de regio's op het gebied van werkgelegenheidsstructuur, leefomgeving etc. Het zal onder meer blijken dat doordat bedrijven een sterke neiging tot clusteren hebben enkele specifieke gemeenten gekenmerkt worden door een grote werkgelegenheidsfunctie in de provincie Overijssel. Werknemers volgen de werkgelegenheid maar hebben een minder sterke neiging om dicht bij elkaar te gaan wonen. In het kader van dit rapport is het met name interessant om na te gaan welke positieve en negatieve effecten gepaard gaan met een werkgelegenheidsfunctie.

In paragraaf 5.2 zal de geografische positie van de provincie Overijssel in kaart gebracht worden en wordt ingegaan op de mobiliteit van afgestudeerden met een hogere opleiding. Vervolgens zal in paragraaf 5.3 het clusteren van werkgelegenheid besproken worden. Om te kunnen bepalen welke positieve en negatieve effecten er zijn, wordt een maatstaf bepaald om gemeenten met een grote werkgelegenheidsfunctie te kunnen onderscheiden. Paragraaf 5.4 zet tenslotte zowel de positieve als de negatieve effecten van overheidsbeleid uiteen voor de provincie Overijssel.

\subsection{De positie van Overijssel}

De provincie Overijssel neemt een belangrijke positie in tussen de Randstad en de Duitse industriegebieden in Nordrein-Westfalen. ${ }^{37}$ Doordat - zoals we ook in hoofdstuk 4 hebben laten zien - de arbeidsmobiliteit tussen Overijssel en het Duitse grensgebied van beperkte omvang is, staat de provincie voor wat de arbeidsmarkt betreft met name onder invloed van de Randstad en kan ook een invloed van de provincie Gelderland en met name het stedelijk knooppunt Arnhem-Nijmegen geconstateerd worden. Voor de goederenmarkt zijn landsgrenzen echter van minder invloed zodat de provincie door haar ligging aantrekkelijk is voor bedrijven die gemakkelijk Duitsland willen kunnen bereiken.

Binnen Nederland heeft de Randstad een zeer grote economische betekenis en daardoor is de aantrekkingskracht van de Randstad op werknemers erg groot. Door de aanzienlijke afstand tussen beide gebieden zijn er niet veel mensen die wonen in Overijssel en werken in de kerngebieden van de Randstad. Verderop in dit hoofdstuk zullen we echter laten zien dat dit niet betekent dat de Randstad geen invloed uitoefent op het pendelgedrag van de Overijsselse bevolking. Veel duidelijker is echter de verhuismobiliteit van Overijssel naar de Randstad. Tabel 5.1a laat voor afgestudeerden van de Overijsselse hogescholen en de Universiteit Twente zien in welke landsdeel zij werkzaam zijn drie jaar na hun afstuderen.

37. Zie hoofdstuk 4 voor meer informatie over de pendel met Duitsland. 
Tabel 5.1a

Verdeling van de werkgelegenheid van in Overijssel afgestudeerden van het hoger onderwijs naar regio en het aantal afgestudeerden werkzaam in Overijssel, als percentage van de afgestudeerden van Overijssel, 1999

Regio

Werkgelegenheid van in Overijssel afgestudeerden naar werkregio

$\%$
Herkomst van afgestudeerden die in Overijssel werken

(als percentage van het aantal afgestudeerden uit Overijssel)

\begin{tabular}{lrr} 
Overijssel & 33 & 33 \\
Noorden & 6 & 6 \\
Randstad & 35 & 8 \\
Zuiden & 21 & 15 \\
Buitenland & 6 & - \\
Totaal & 100 & 62 \\
\hline
\end{tabular}

Bron: CHEERS

Uit tabel 5.1a blijkt dat van elke 100 afgestudeerden van de Overijsselse hogescholen en de Universiteit Twente er 33 in Overijssel blijven, 35 naar de Randstad gaan om te werken en 21 naar het zuiden verhuizen. Een grote mobiliteit van afgestudeerden hoeft geen grote effecten voor Overijssel te hebben als ook afgestudeerden uit andere regio's in vergelijkbare mate naar Overijssel trekken. Uit de tabel blijkt echter dat dit niet het geval is. Tegenover iedere 100 in Overijssel afgestudeerden van het hoger onderwijs staan 15 afgestudeerden die vanuit het zuiden naar Overijssel komen om te werken. Vanuit de Randstad komen per 100 afgestudeerden uit Overijssel slechts 8 afgestudeerden naar Overijssel. De aantrekkende kracht van provincies ten noorden van Overijssel en de invloed van het buitenland is betrekkelijk klein. Zowel naar de drie noordelijke provincies als naar het buitenland vertrekt slechts $6 \%$ van de afgestudeerden. Dit betekent dat de balans voor de provincie Overijssel negatief is. Ze verliezen 67 afgestudeerden aan andere regio's (inclusief het buitenland) en krijgen er 29 voor in de plaats. Op elke 100 afgestudeerden die de provincie aflevert, gaan er dus slechts 62 in Overijssel werken. $^{38}$

38. Overigens is hierbij geen rekening gehouden met de komst van buitenlandse hoger opgeleiden naar Nederland. 
Tabel $5.1 b$

Verdeling van in Overijssel afgestudeerden van het hoger onderwijs over Nederland naar provincie en het aantal afgestudeerden dat werkzaam is in Overijssel, als percentage van de afgestudeerden van Overijssel, 1999

Regio

Werkgelegenheid van in Overijssel afgestudeerden naar werkprovincie $\%$

Herkomst van afgestudeerden die in Overijssel werken (als percentage van het aantal afgestudeerden uit Overijssel)

$\%$

$\begin{array}{lrr}\text { Overijssel } & 33 & 33 \\ \text { Groningen } & 3 & 1 \\ \text { Friesland } & 1 & 2 \\ \text { Drenthe } & 2 & 2 \\ \text { Noord-Holland } & 12 & 3 \\ \text { Zuid-Holland } & 12 & 2 \\ \text { Utrecht } & 9 & 3 \\ \text { Flevoland } & 2 & 0 \\ \text { Gelderland } & 15 & 12 \\ \text { Zeeland } & 0 & 0 \\ \text { Noord-Brabant } & 4 & 2 \\ \text { Limburg } & 2 & 1 \\ \text { Buitenland } & 6 & - \\ \text { Totaal } & & 2\end{array}$

Bron: CHEERS

Tabel 5.1b laat de uitsplitsing zien naar provincie. Opvallend is dat van de 100 in Overijssel afgestudeerden er 15 naar de aangrenzende provincie Gelderland gaan, terwijl er maar 12 afgestudeerden vanuit Gelderland naar Overijssel komen om te werken. Een groter verschil in stromen van afgestudeerden is te zien bij NoordHolland en Zuid-Holland. Er zullen 12 van de 100 in Overijssel afgestudeerden naar deze provincies vertrekken vanuit Overijssel om te werken, terwijl slechts 3 respectievelijk 2 vanuit deze provincies naar Overijssel komen om te werken. Deze vrij omvangrijke stroom van afgestudeerden naar de Randstad - die uiteraard ook in andere provincies optreedt - weerspiegelt dat in Nederland veel werkgelegenheid, met name voor hoger opgeleiden zich in de Randstad lijkt te concentreren. De bevolking heeft zich dus over het land verspreid waarbij werkgelegenheid een bepalende factor is van dit spreidingsgedrag. Ook in de prognoses voor de baanopeningen kwam tot uiting dat de vraag naar hoger opgeleiden in Overijssel minder groot is dan in Nederland als geheel. ${ }^{39}$

39. Zie figuur 3.8 in hoofdstuk 3 van dit rapport. 


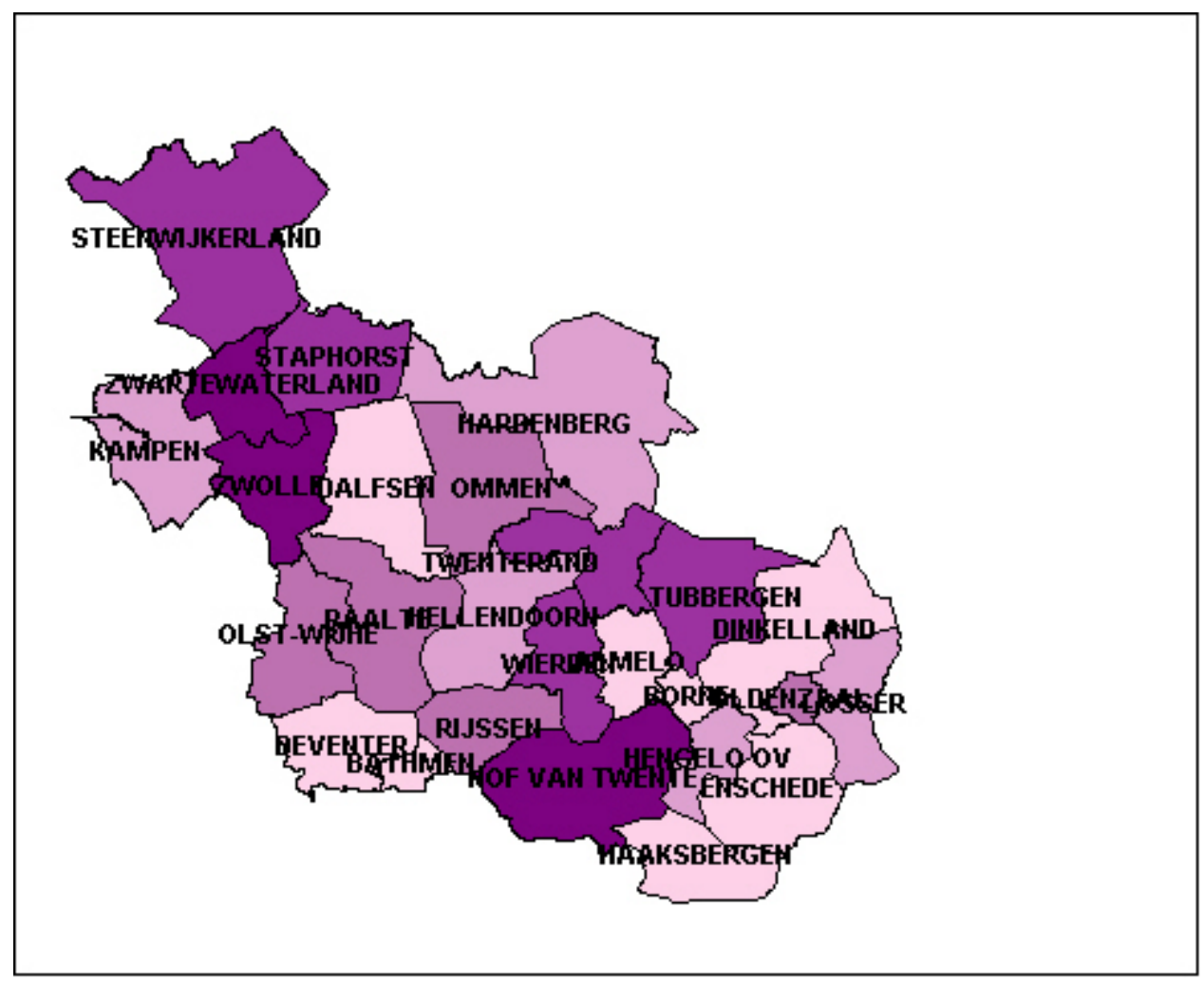

\subsection{Het clusteren van werkgelegenheid}

Met name bedrijven die veel hoger opgeleiden in dienst nemen lijken bij hun vestigingskeuze een voorkeur te hebben voor de Randstad. Deze vestigingbeslissing zal zeker op langere termijn gebaseerd zijn op een afweging van de kosten en de baten. Aan de batenkant van deze afweging blijkt dat bedrijven in het algemeen een grote voorkeur hebben om zich te vestigen in de buurt van andere bedrijven en op locaties met een goede infrastructuur. Bedrijven blijken er enorm baat bij te hebben om zich te vestigen in plaatsen waar ook veel andere bedrijven zitten. Voordelen zijn dat leveranciers en afnemers in de buurt zitten, en er geprofiteerd kan worden van het beschikbare aanbod van gekwalificeerd personeel. Verder zijn er duidelijke aanwijzingen dat er sprake is van substantiële kennis-spillovers. Omdat werknemers van verschillende bedrijven elkaar sneller ontmoeten kan het ene bedrijf profiteren van de kennis-ontwikkeling van andere bedrijven. Doordat in steden en agglomeraties waar veel bedrijven gevestigd zijn ook de infrastructuur beter zal zijn, wordt de neiging tot clusteren nog verder versterkt. Dat betekent dat de grote concentratie van bedrijven in de Randstad aantrekkelijk is voor andere bedrijven waardoor de concentratie alleen nog maar toeneemt.

Tegenover deze voordelen van clustering staan echter ook nadelen. Door de spreiding van de bevolking zal het immers drukker worden en de schaarste zal toenemen. Er ontstaan opstoppingen in het verkeer, de grondprijs zal stijgen en het 76 
wordt moeilijker voor het personeel om een redelijke woonruimte te vinden. Door deze congestie-effecten zal de neiging tot clustering van bedrijven begrensd worden.

Bedrijven worden aangetrokken door de concentratie van andere bedrijven, en dragen vervolgens door hun vestiging hier weer verder aan bij. Van belang voor een goed begrip van deze dynamiek is dat bedrijven in hun vestigingskeuze wel rekening zullen houden met de voordelen van de aanwezigheid van andere bedrijven, maar geen rekening zullen houden met de positieve en negatieve effecten die zij op hun beurt weer veroorzaken. Zij zullen immers zelf niet de baten en de lasten van deze effecten ervaren. Een consequentie hiervan is dat de neiging tot clustering van werkgelegenheid waarschijnlijk veel sterker is dan wat maatschappelijk optimaal is. Als een bedrijf moet kiezen of het zich in een grote of een kleine stad zal vestigen zal het wel rekening houden met het feit dat er meer positieve effecten van andere bedrijven in die grote stad te verwachten zijn, maar zal het er geen rekening mee houden dat de betekenis van het bedrijf in de kleinere stad voor andere bedrijven en de maatschappij als geheel waarschijnlijk veel groter zijn.

Juist doordat voor bedrijven clustering zo belangrijk blijkt te zijn, kan een beperkte stimulans van de werkgelegenheid een veel groter effect op de werkgelegenheidsstructuur hebben. Om een dergelijk proces op gang te brengen kan de vestiging van specifieke bedrijven worden gestimuleerd of kan door extra investeringen in de infrastructuur een stimulans worden gegeven aan bedrijven om zich in de provincie te vestigen. De infrastructuur en met name de bereikbaarheid van bepaalde regio's zijn immers belangrijke elementen bij de vestigingskeuze van bedrijven. De bereikbaarheid van stedelijke gebieden is van groot belang aangezien de bedrijven graag goed bereikbaar zijn voor zowel hun leveranciers en klanten als hun medewerkers. Het vestigingsklimaat voor bedrijven speelt dus een belangrijke rol bij de opkomst van bepaalde bedrijfstakken in een regio. Doordat specifieke bedrijven zich in een regio vestigen wordt ook de arbeidsmarkt van die regio gekenmerkt door specifieke werkgelegenheid. Het vestigen van een chemieconcern in Twente zal ertoe leiden dat er vacatures zullen ontstaan voor chemisch en technisch opgeleiden. Naast de bereikbaarheid van de bedrijven in logistieke zin is het van belang dat de bedrijven ook toegang hebben tot de kennisinfrastructuur van universiteiten en hogescholen. ${ }^{40}$

Bij innovatiebeleid is het van belang dat er sprake is van kennisuitwisseling. Deze kennisuitwisseling hoeft niet alleen tussen bedrijven plaats te vinden maar ook uitwisseling tussen bedrijven en plaatselijke universiteiten en hogescholen is van groot belang. De ontwikkelingen in kennis die voortvloeien uit innovaties zijn zeer belangrijk voor de economische groei. Bedrijven en instellingen hebben op deze manier baat bij een kleine geografische afstand tot elkaar.

Kennisuitwisseling wordt onder andere bevorderd door het clusteren van bedrijven en instellingen zoals universiteiten en hogescholen. In Enschede bijvoorbeeld is een Business \& Science Park gevestigd waarbij bedrijven gebruik kunnen maken van de

40. Zie www.sciencepark.nl. 
faciliteiten van Universiteit Twente. ${ }^{41}$ Hierdoor wordt zowel kennisuitwisseling bevorderd als productontwikkeling. Samen met de Universiteit Twente en de voormalige Overijsselse Ontwikkelingsmaatschappij (OOM, nu Oost NV) worden hightech starters gestimuleerd zich te vestigen in deze regio. ${ }^{42}$ De Universiteit Twente heeft bijvoorbeeld een TOP-regeling (Tijdelijke Ondernemers Plek) waarbij studenten gestimuleerd worden na hun studie een eigen bedrijf te starten. Door de aanwezigheid van universiteiten en hogescholen is er veel kennis aanwezig in termen van human capital. Het vestigingsklimaat voor bedrijven zal daardoor goed zijn. Innovatie is derhalve een belangrijk middel om productie efficiënter en effectiever te laten zijn. Beleid dat gericht is op het stimuleren van innovatieve activiteiten legt onder andere de nadruk op de kennisinfrastructuur. Bij deze infrastructuur gaat het om de interactie en met name de aansluiting tussen het publieke kennisaanbod (universiteiten en hogescholen) en de kennisvraag van bedrijven.

\subsection{Effecten van beleid}

Het beleid dat de overheid voert om werkgelegenheid gelijkmatiger te verspreiden over alle regio's binnen Nederland, waarbij tevens aandacht wordt geschonken aan het innovatieklimaat binnen Nederland, beoogt de positieve effecten van dergelijke bedrijvigheid beter te benutten. Dit heeft niet alleen positieve effecten voor de inwoners van de betreffende regio, maar ook de omringende regio's kunnen profiteren van de gevestigde bedrijven. Tevens beoogt het beleid minder drukte (verkeer, congestie, milieuvervuiling) in regio's waar voornamelijk werkgelegenheid is gevestigd waardoor andere regio's geconfronteerd zullen worden met dergelijke negatieve effecten. Het ligt voor de hand om te veronderstellen dat grote agglomeraties minder nadeel ondervinden als enkele innovatieve bedrijven zich niet daar maar in een regionale werkgelegenheidskern zouden vestigen, dan de voordelen die de betreffend regio daarvan ondervindt. Allereerst verkleint een dergelijke verschuiving de congestie in het geagglomereerde gebied, maar daarnaast kan ook verwacht worden dat de betekenis van de spill-over effecten van zo'n bedrijf in de regio groter is dan in een grote agglomeratie.

Het beleid dat de overheid voert heeft zowel een korte als een lange termijn effect. ${ }^{43}$ Op de korte termijn leiden publieke investeringen (overheidsbeleid) tot het stimuleren van economische activiteiten in een regio. Het langetermijneffect wordt veroorzaakt doordat publieke investeringen publiek kapitaal creëren zoals de infrastructuur in een bepaalde regio. Op de lange termijn hebben de opbrengsten van publiek kapitaal een grote invloed op de productiviteit van de private sector. Door het verbeteren van de infrastructuur in een bepaalde regio wordt de bereikbaarheid van de bedrijven verbeterd waardoor deze gekenmerkt zullen worden door een hogere productiviteit.

41. Zie www.sciencepark.nl.

42. Zie www.oostnv.nl.

43. Volgens N. Yamano en T. Ohkawara (2000) The regional allocation of public investment: efficiency or equity?, Journal of Regional Science, Vol. 40, pp. 205-229. 
Figuur 5.1

Het aantal werkenden als percentage van het aantal inwoners per gemeente voor de provincie Overijssel, 2001

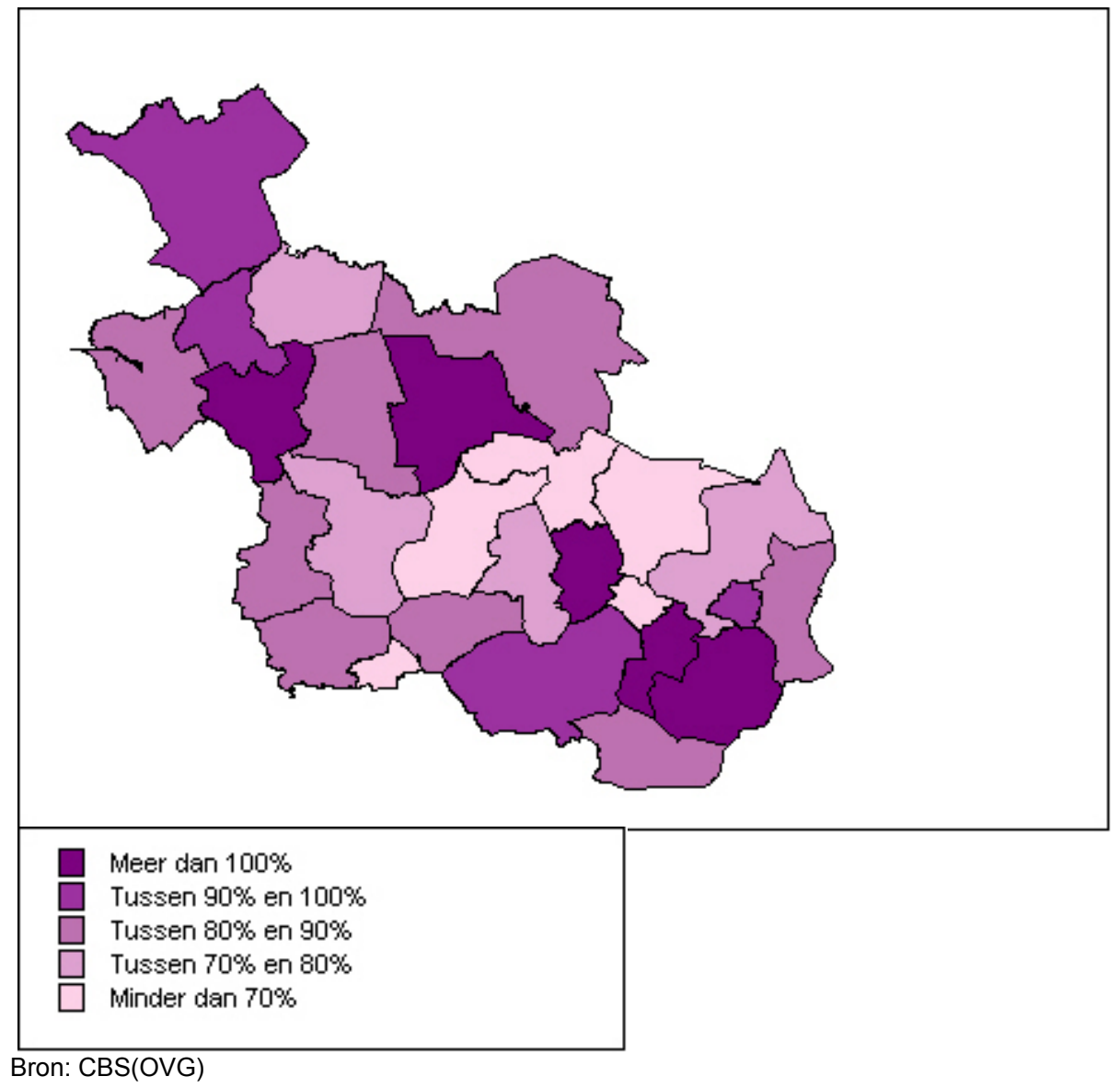

Overigens blijkt uit de literatuur dat er in de praktijk vaak sprake is van regionale competitie, waardoor het effect van inspanningen van een regio deels te niet wordt gedaan door inspanningen van andere regio's om de innovatieve werkgelegenheid te stimuleren. In Nederland blijken met name de regio's die tegen de Randstadprovincies aanliggen veel te investeren in regionaal innovatiebeleid. ${ }^{44}$ Zo blijkt dat de innovatiegraad van het Nederlandse midden- en kleinbedrijven (MKB) voor de industriesector gemiddeld zo'n $58 \%$ bedraagt. Voor de provincie Overijssel is dit bijna $60 \%$ terwijl Flevoland bijvoorbeeld $66 \%$ als innovatiegraad heeft in deze sector.

De werkgelegenheidsstructuur in een land kan het beste worden weergegeven vanuit het perspectief van werkgelegenheidscentra. Hoewel er altijd een aanzienlijke groep mensen is die werkt in de gemeente waar men woont, blijken er een aantal centra te zijn waar het aantal banen groter is dan de werkende beroepsbevolking, terwijl in de

44. CBS, (1999), Innovatie en provincie, Regionale innovatieprofielen in Nederland, Den Haag. 
meeste gemeenten meer werkenden wonen dan dat er banen zijn. De bevolking spreidt dus meer uit over de gemeenten dan de werkgelegenheid.

Figuur 5.1 geeft het aantal werkenden weer voor de provincie Overijssel (per gemeente) als percentage van het aantal inwoners. Hierbij zijn om de balans zuiver te houden alleen Nederlanders met een baan meegerekend bij de inwoners. Het blijkt dat de gemeenten Enschede, Hengelo, Almelo, Zwolle en Ommen de meeste werkenden hebben per inwoner. Alleen bij deze gemeenten komt deze verhouding boven $100 \%$ uit. In Overijssel is de verhouding werkenden-wonenden het hoogst in Almelo en Zwolle. Dit is vergelijkbaar met plaatsen als Assen en Arnhem in andere provincies. De hoogste verhoudingen in Nederland worden behaald door Amsterdam, Rotterdam en Utrecht. De gemeenten met de laagste verhouding tussen werkenden en wonenden zijn Borne, Tubbergen, Vriezenveen, Hellendoorn en Raalte. Bij deze plaatsen varieert deze verhouding tussen de $60 \%$ en $75 \%$.

Omdat werkgelegenheid weer mensen aantrekt zullen in werkgelegenheidskernen ook relatief veel mensen wonen. De verhouding tussen het aantal werkenden en wonenden per gemeente zal daarom slechts ten dele de concentratie van werk weerspiegelen. Een alternatieve maat om werkgelegenheidskernen aan te duiden is daarom het aantal werkenden per hectare. Als er veel werkenden zijn per hectare hebben zich namelijk veel bedrijven of relatief grote bedrijven gevestigd in die gemeente.

Figuur 5.2 geeft het aantal werkenden weer per gemeente voor de provincie Overijssel rekening houdende met de oppervlakte van de gemeenten. Hieruit blijkt dat de gemeenten Enschede, Hengelo, Almelo en Zwolle de meeste werkenden per hectare bevatten. De hoogste werkgelegenheidsdichtheid wordt in Overijssel aangetroffen in Zwolle en Hengelo. Hier is dit verhoudingscijfer resp. 400 en 370 werkenden per hectare.

Landelijk gezien nemen ruim $70 \%$ van de gemeenten een lagere positie in dan Zwolle en de dichtheid is vergelijkbaar met plaatsen als Tiel, Wageningen, Heemstede, Den Helder, Helmond en Oss. De hoogste dichtheden in Nederland worden aangetroffen in Leiden, Haarlem en Nijmegen. De gemeenten Dalfsen, Ommen, OlstWijhe, Staphorst en Tubbergen bevatten de minste werkenden per hectare. De dichtheid varieert hier van 20 tot 30 . Het beeld op basis van de dichtheid per hectare komt overigens grotendeels overeen met het aantal werkenden als percentage van het aantal wonenden per gemeente. 
Figuur 5.2

Het aantal werkenden per hectare per gemeente voor de provincie Overijssel, 2001

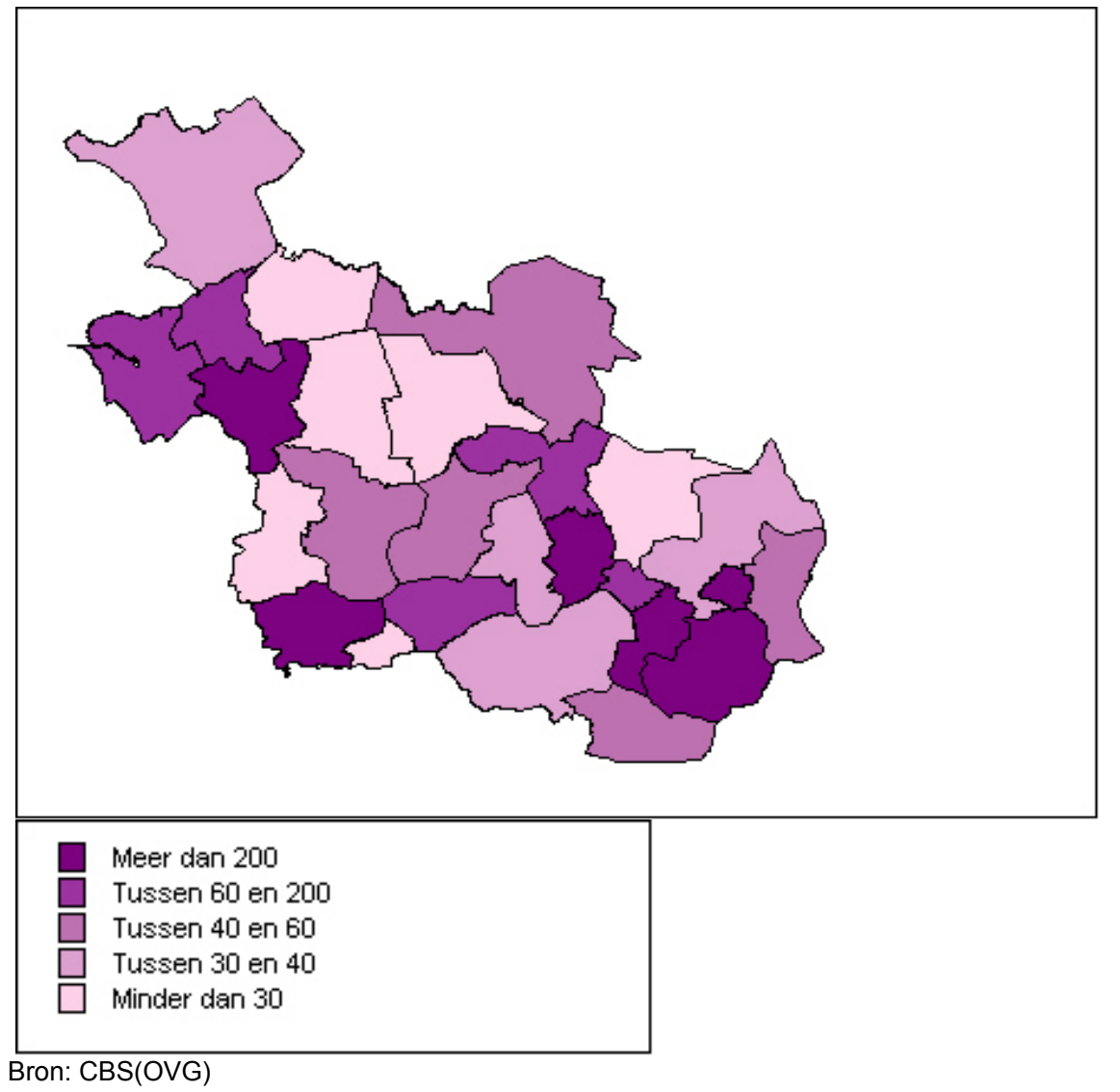

\section{Positieve externaliteiten}

Binnen Nederland bestaat er dus niet alleen een sterke neiging van bedrijven om zich te clusteren in de Randstad, maar zijn er ook buiten de Randstad kernen te onderscheiden waar de regionale werkgelegenheid zich concentreert. Voor Overijssel gaat het hier met name om Twente en Zwolle. Het is vaak moeilijk om precies aan te geven wat de voordelen voor bedrijven zijn om zich in deze werkgelegenheidskernen te vestigen, maar deze voordelen blijken wel aanzienlijk te zijn. Deze positieve spillovers moeten tot uitdrukking komen in een hogere arbeidsproductiviteit. Deze hogere arbeidsproductiviteit kan worden afgemeten aan de gemiddelde hogere lonen.

Verschillen tussen regio's in termen van arbeidsproductiviteit worden dus niet alleen veroorzaakt door overheidsbeleid. Regionale verschillen in arbeidsproductiviteit kunnen ook veroorzaakt worden door verschillen in opleidingsniveau van de regionale beroepsbevolking. Een lager gemiddeld opleidingsniveau in een bepaalde regio leidt tot het vestigen van bedrijven voor welke een dergelijk kwalificatieniveau 
van werknemers voldoet. Naast verschillen in de samenstelling van de beroepsbevolking kunnen ook agglomeratie effecten leiden tot regionale verschillen in arbeidsproductiviteit. Hierbij wordt met agglomeratie effecten bedoeld alle effecten die bedrijven in drukke (compacte) economische gebieden productiever maakt. Regio's waarin veel bedrijven zich gevestigd hebben zullen gekenmerkt worden door effecten zoals nieuwe technologieën die sneller worden ingeruild en aangenomen. ${ }^{45}$ Naast het aannemen van nieuwe technologieën is het door het grote volume van bedrijven winstgevend om een grote variëteit van gespecialiseerde diensten aan te bieden. Al deze effecten hebben een grote invloed op het vestigingsgedrag van bedrijven. $^{46}$

Gemeenten met veel werkgelegenheid worden doorgaans gekenmerkt door een hoger percentage werkenden met een hoger opleidingsniveau en een hoger gemiddeld loon. Deels is dit hogere loon natuurlijk een gevolg van het hogere opleidingsniveau van de werkenden, maar ook als gecorrigeerd wordt voor opleidingsachtergrond blijken de lonen in werkgelegenheidkernen hoger te liggen dan elders. Omdat bedrijven zich alleen hogere lonen kunnen permitteren als daar ook een hogere productiviteit tegenover staat, kunnen deze loonverschillen gezien worden als een reflectie van de productiviteitsverschillen tussen werkgelegenheidskernen en andere plaatsen.

Uit analyses voor heel Nederland blijkt dat een gemeente met 100 werkenden meer per hectare gemiddeld $4,2 \%$ hogere lonen heeft. Als gecorrigeerd wordt voor de opleidingssamenstelling van de werkenden in die gemeente, blijken de lonen 1,3\% hoger te liggen. Dus een groot deel van de loonverschillen wordt verklaard aan de hand van het opleidingsniveau, maar ook als gecorrigeerd wordt voor opleidingsverschillen blijven er nog substantiële loonsverschillen bestaan.

Figuur 5.3 geeft de gemiddelde lonen gecorrigeerd voor opleidingsniveau van de werkenden weer per gemeente voor de provincie Overijssel. Hieruit komt naar voren dat ook in Overijssel de hoogste lonen worden betaald in of rond de werkgelegenheidskern Zwolle. Als bijvoorbeeld Zwolle met Wierden wordt vergeleken gaat het hierbij om een verschil van zo'n 5\%. Uit figuur 5.3 blijkt dat vooral Deventer en Zwolle gekenmerkt worden door gemiddeld hogere lonen. De gemeenten Hengelo en Enschede, die ook gekenmerkt worden door veel werkgelegenheid, behoren blijkbaar niet tot de gemiddeld hoogste inkomens.

De voordelen voor bedrijven om te clusteren in werkgelegenheidscentra blijken groter te zijn voor de werkgelegenheid van hoger opgeleiden. Zo blijken de loonsverschillen van hoger opgeleiden tussen werkgelegenheidscentra en andere gemeenten veel groter te zijn dan de gemiddelde verschillen die hierboven werden aangegeven. Daarnaast komt ook duidelijk naar voren dat in werkgelegenheidscentra relatief meer hoger opgeleiden werken. Uit de analyse voor heel Nederland blijkt dat

45. Volgens A. Ciccone (2001), Agglomeration effects in Europe and the USA, Els Opuscles del CREI, no. 9, Spain.

46. Volgens B.A. Blonigen and V. Kolpin (2002), Technology, agglomeration, and regional competition for investment, NBER Working Paper 8862. 
als in een gemeente de werkgelegenheid per hectare 100 hoger is, het percentage hoger opgeleiden onder de werkenden met $4,2 \%$ toeneemt. In de appendix kan men zien dat in Overijssel Zwolle met $36 \%$ het hoogste percentage hoger opgeleiden onder de werkenden kent, tegenover $8 \%$ in Hellendoorn, $9 \%$ in Ommen en $10 \%$ in Tubbergen. Ook in Borne, Deventer, Enschede is meer dan $30 \%$ van de werkenden hoger opgeleid.

\section{Figuur 5.3}

Het gemiddelde loon gecorrigeerd voor opleidingsniveau per gemeente voor de provincie Overijssel, 2001

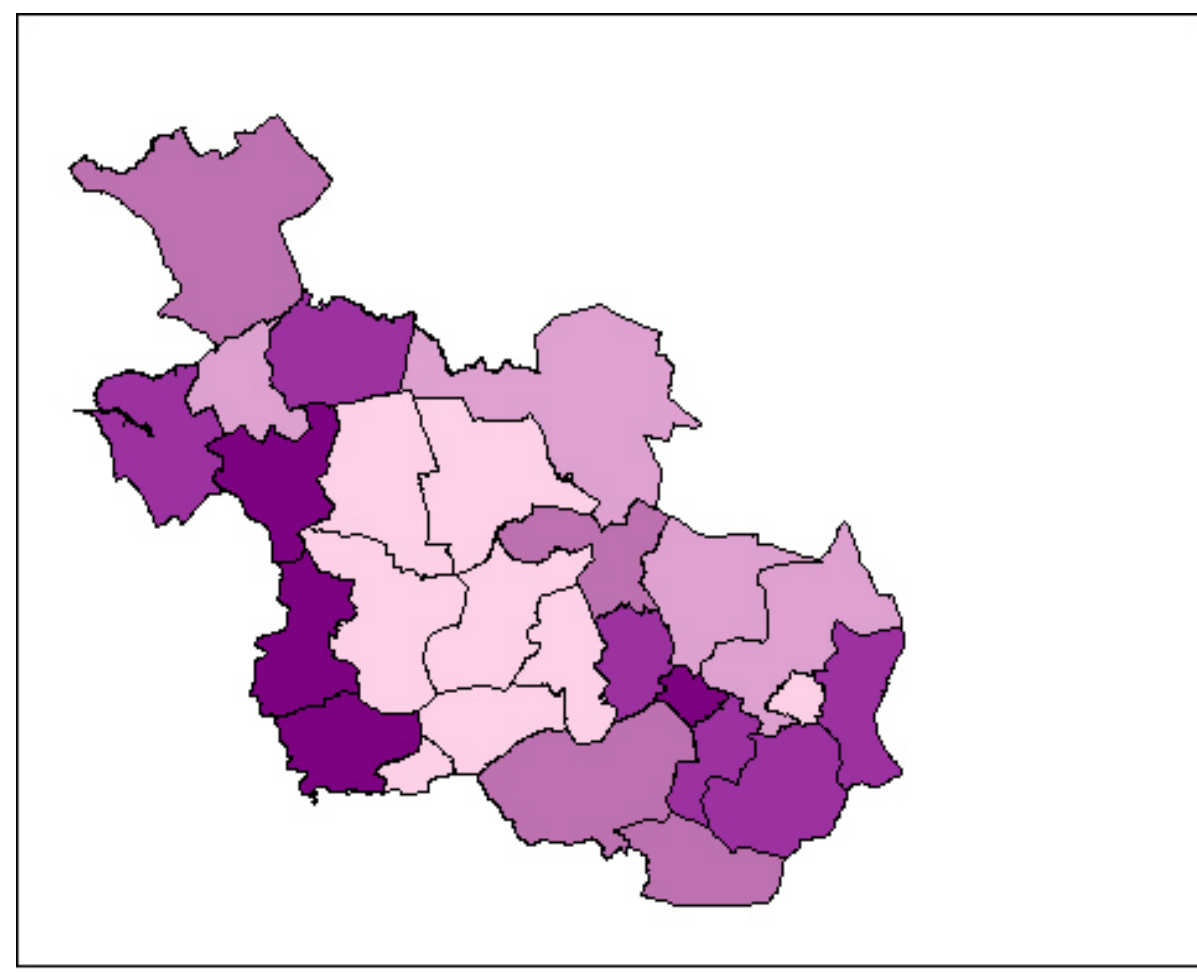

Meer dan 18.800 euro

Tussen 18.000 en 18.800 euro

Tussen 17.800 en 18.000 euro

Tussen 17.300 en 17.800 euro

Minder dan 17.300 euro

Bron: CBS (OVG)

Zwolle en Twente zouden waarschijnlijk ook zonder regionaal beleid werkgelegenheidscentra in de provincie Overijssel zijn geweest. Met name Zwolle zal hierbij profiteren van de relatief korte afstand tot Utrecht. Verwacht kan echter worden dat met name voor Twente een stimuleringsbeleid (en natuurlijk de aanwezigheid van de technische universiteit) heeft bijgedragen aan de aantrekkelijkheid als vestigingsplaats voor bedrijven, waardoor meer hoger opgeleiden in die regio werkzaam zijn en 
de productiviteit hoger zal liggen. Doordat innovatieve bedrijven zich gaan vestigen in de provincie Overijssel zullen pas afgestudeerden van hogescholen en de Universiteit Twente minder geneigd zijn naar de Randstad te gaan om een baan te vinden. Door de toegenomen werkgelegenheid in de provincie zullen ook meer mensen zich vestigen in de provincie.

\section{Negatieve externaliteiten}

Clustering van werkgelegenheid en mensen heeft niet alleen positieve externe effecten voor de productiviteit en de bevolking. Tegenover deze positieve effecten van werkgelegenheidskernen staan echter ook nadelen als gevolg van de optredende congestie. Hierbij kan gedacht worden aan de effecten die een toegenomen welvaart, productieniveau en bevolking hebben op de infrastructuur en het milieu van de provincie Overijssel. Doordat er bijvoorbeeld meer mensen werken in Overijssel, zal het verkeer toenemen. Het leven in een drukke stad is duurder (met name de grondprijs zal hoger zijn), er is minder ruimte beschikbaar en de reistijden zijn langer.

Zowel voor bedrijven als voor mensen zijn er dus naast de voordelen van werkgelegenheidskernen ook nadelen verbonden aan de vestiging in dergelijke centra. In het algemeen blijken de voordelen voor bedrijven groter te zijn dan voor mensen en de nadelen groter voor mensen dan voor bedrijven. Het gevolg hiervan is dat het werk zich sterker concentreert dan de wonenden en mensen dus moeten gaan pendelen om op hun werk te komen.

De afweging om zich in een werkgelegenheidskern te vestigen of een grotere afstand hiervan te nemen zal niet voor elk bedrijf of voor elke persoon gelijk liggen. Zoals hierboven is opgemerkt blijken met name bedrijven die hoger opgeleiden in dienst hebben meer baat te hebben van vestiging in werkgelegenheidscentra dan andere bedrijven. Naarmate het drukker wordt in een stad en de nadelen toenemen zullen bedrijven die het minst profiteren van deze spillover-effecten als eerste besluiten om zich buiten een werkgelegenheidskern te vestigen. Het gevolg is dus dat met name de werkgelegenheid voor hoger opgeleiden zich in de werkgelegenheidscentra concentreert.

Ook voor personen hoeft de afweging tussen wonen in een werkgelegenheidscentrum of daarbuiten niet voor iedereen gelijk te zijn. Er moet immers een afweging gemaakt worden tussen de nadelen van duurder wonen en langer reizen. Omdat bij een groot huis de besparing op de kosten door goedkoper te gaan wonen veel hoger is dan bij een klein huis en de mogelijkheid om te kiezen voor goedkopere vormen van vervoer beperkt zijn, gaan juist de mensen met hogere inkomens op grotere afstand van het werk wonen en nemen ze de hogere kosten (en tijdsverlies) van pendelen voor lief om daarmee rustiger te kunnen wonen en een groter huis te kunnen kopen.

De keuze van een werkende om al dan niet te gaan reizen om een werkgemeente te bereiken hangt af van een aantal factoren. Tabel 5.2 geeft een overzicht van deze factoren met de effecten van deze factoren op de keuze om te pendelen. Zo blijkt dat 
mannen doorgaans een hogere kans hebben om te pendelen vergeleken met vrouwen. De leeftijd van werkenden heeft een negatief effect op de kans om te pendelen, naarmate werkenden ouder worden wordt de kans kleiner dat ze gaan pendelen. Voor het inkomen, opleidingsniveau en aantal werkzame uren geldt een positief effect op de kans om te pendelen. Mensen die meer verdienen, een hoger opleidingsniveau hebben of doorgaans meer dan 30 uur werken per week hebben een grotere kans om te gaan pendelen vergeleken met mensen die deze achtergrondkenmerken niet hebben.

Tabel 5.2

De keuze van een werkende om te gaan pendelen om de werkgemeente te bereiken, 2001

Factoren Kans dat een werkende gaat pendelen

\author{
Geslacht (man) \\ Leeftijd \\ Inkomen \\ Opleidingsniveau \\ Aantal werkzame uren
}

Bron: CBS (OVG)

Overigens woont in de meeste gevallen de meerderheid van de mensen in dezelfde gemeente als waar ze werk hebben. De keuze van werkenden om in een andere gemeente te gaan wonen hangt van een aantal factoren af. Zo blijken meer mensen in een andere gemeente te gaan wonen dan waar ze werken als de afstand tot die gemeente kleiner is. Tevens blijkt - zoals verwacht kon worden - dat de grootte van de werkgemeente (in termen van aantal werkenden per hectare) invloed heeft op de woonkeuze van werkenden. Naarmate de werkgemeente groter is zijn mensen eerder geneigd elders te gaan wonen. Tegenover de hogere productiviteit die in werkgelegenheidscentra gerealiseerd kan worden staat dus dat mensen vaker uit moeten wijken naar andere plaatsen om een aantrekkelijke woning te kunnen vinden.

In verband hiermee geeft figuur 5.4 het pendelpercentage weer per gemeente. Deze wordt bepaald door het totaal aantal pendelaars te delen door de werkgelegenheid van de betreffende gemeenten. Hieruit blijkt dat ook gemeenten rondom de werkgelegenheidscentra veel pendelaars bevatten, deze gemeenten worden ook wel 'slaapsteden' genoemd.

Hoewel er niet veel mensen zijn die in Overijssel wonen en in de Randstad werken is echter toch bij de keuze van de woongemeente de invloed van de Randstad merkbaar. Doordat in de Randstad zeer veel werkgelegenheid is geconcentreerd, wijken veel mensen die daar werken uit. Deze mensen zijn gaan wonen in de gebieden rondom de Randstad. Personen die weer in deze gebieden werken worden daarom geconfronteerd met relatief hoge prijzen voor woningen en hebben daardoor de neiging meer naar het Oosten of Zuiden op te schuiven bij de keuze van een woning. De verhoging van de prijs van woningen schuift daardoor langzaam door, waardoor ook in Overijssel dit effect merkbaar is. 
Figuur 5.4

Pendelpercentage (aantal pendelaars/aantal werkenden) per gemeente voor de provincie Overijssel, 2001

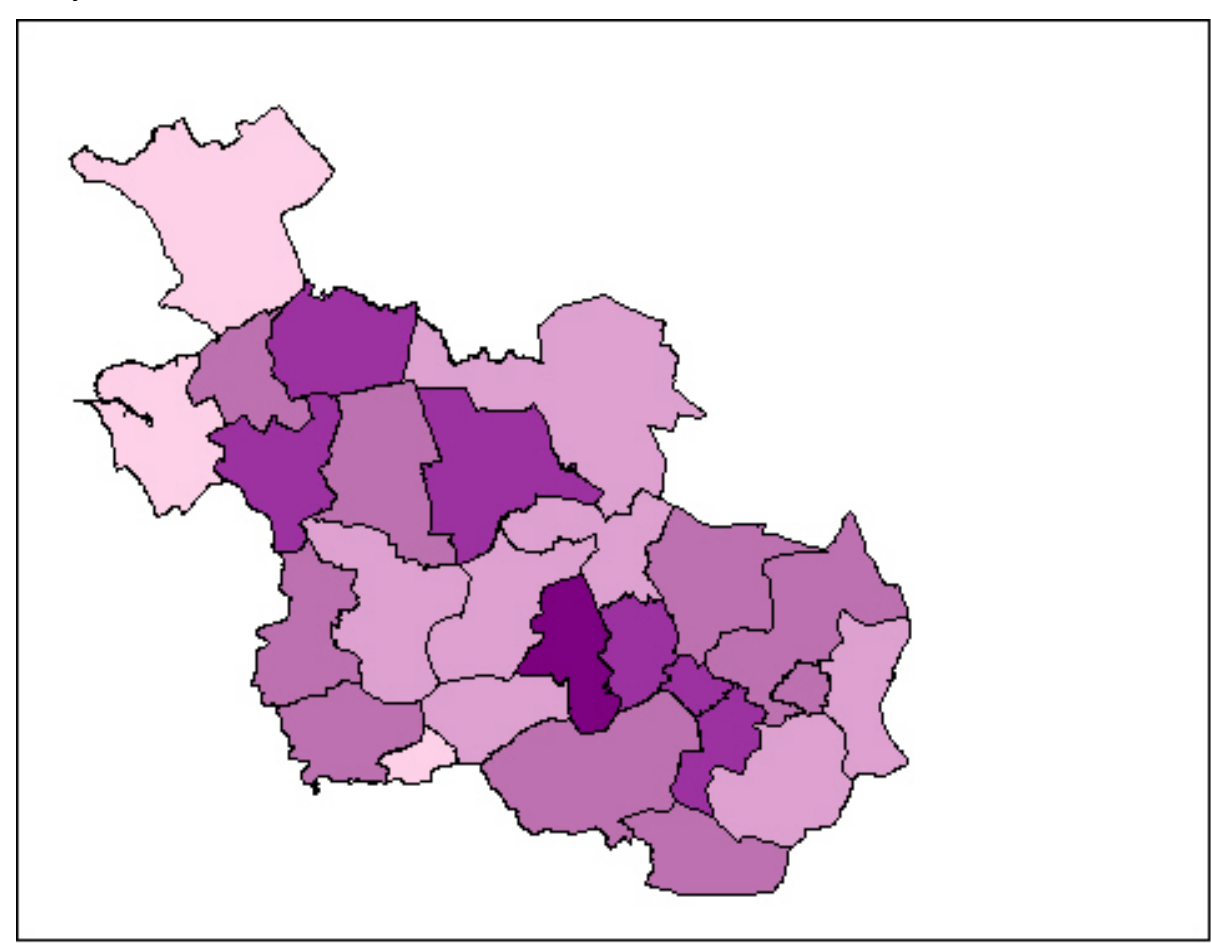

Meer dan $50 \%$

Tussen $40 \%$ en $50 \%$

Tussen $30 \%$ en $40 \%$

Tussen $20 \%$ en $30 \%$

Minder dan $20 \%$

Bron: CBS (OVG)

In figuur 5.5 wordt voor alle werkenden uit een gemeente met pijlen aangegeven waar de gemiddelde werkplek zich bevindt. Hoewel de afstand tussen woning en werk gemiddeld erg laag is - veel mensen werken immers in de plaats waar ze ook wonen - kan wel geconstateerd worden dat deze pijlen relatief vaak naar het ZuidWesten wijzen.

Een dikke pijl in figuur 5.5 houdt in dat er veel mensen gemiddeld genomen die richting uitgaan om hun werklocatie te bereiken. De dikte van de pijl geeft dus het aantal pendelaars weer terwijl de lengte van de pijl de gemiddelde afstand weerspiegelt. Zo blijkt dat relatief veel mensen vanuit Enschede richting Hengelo gaan. Dit geldt ook voor de omliggende gemeenten Haaksbergen, Losser, Rijssen en Dinkelland. Andere gemeenten zoals Deventer, Hof van Twente, Zwolle, Kampen en Steenwijkerland laten duidelijk zien dat de pendelaars richting het Westen reizen. Gemiddeld genomen werken mensen dus dichter bij de Randstad en wonen ze dichter bij de Duitse grens en de noordgrens van de provincie. 
Figuur 5.5

De gemiddelde richting van de pendelaars van Overijssel, 2001

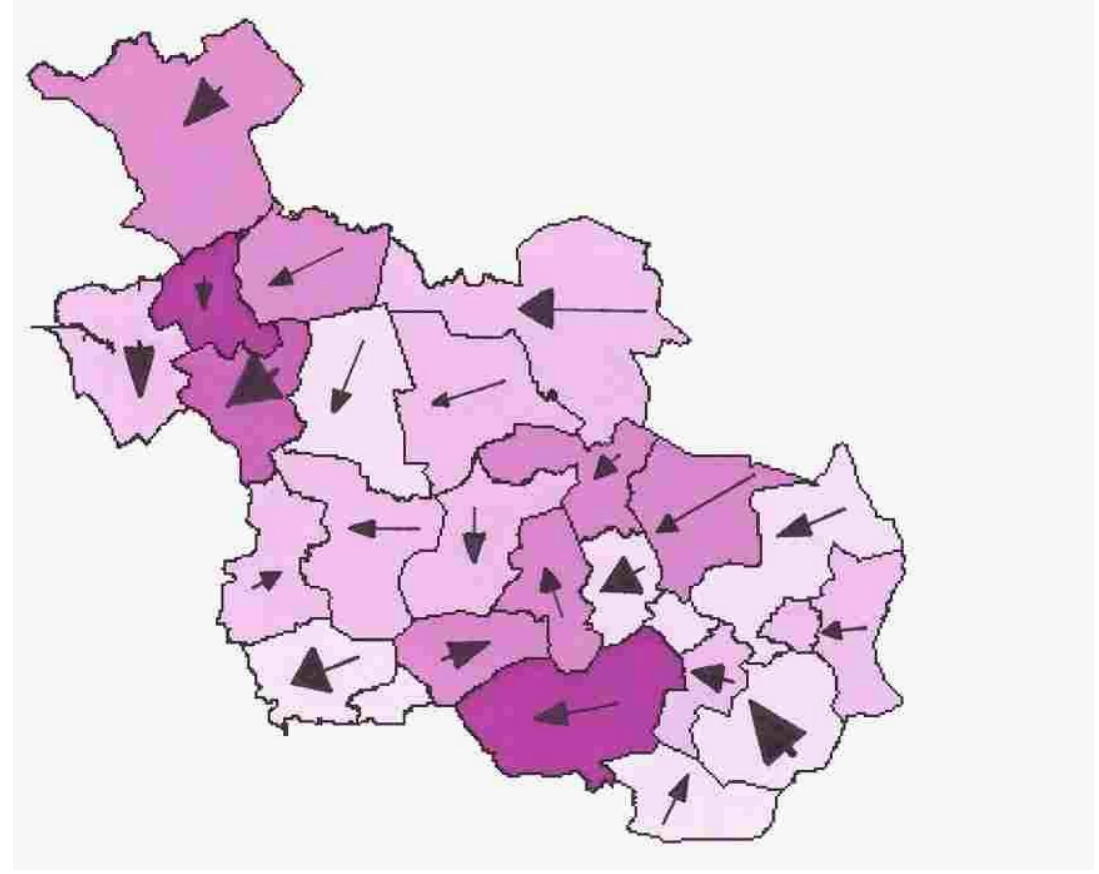

Bron: CBS (OVG)

Een andere negatieve consequentie van werkgelegenheidscentra zou moeten zijn dat de grond schaarser is en dus de grondprijs, en daarmee de kosten van wonen, hoger. Uit figuur 5.6 blijkt echter dat gemeenten met veel werkenden doorgaans gekenmerkt worden door lagere gemiddelde prijzen voor huizen. De reden hiervoor is dat in de statistieken huizenprijzen niet worden gecorrigeerd voor de kwaliteit en omvang van deze woningen. Aan de ene kant zal de prijs voor een gelijkwaardige woning in een werkgelegenheidscentrum hoger zijn dan daarbuiten, maar aan de andere kant hebben juist werkenden met een hoog inkomen de neiging om buiten de stad te gaan wonen. Uiteraard huren of kopen mensen met een hoger inkomen gemiddeld ook duurdere woningen. De balans van deze effecten is dat in de werkgelegenheidscentra goedkopere woningen worden aangetroffen dan daarbuiten. Met name de gemeenten rondom deze werkgelegenheidscentra hebben aanmerkelijk hogere prijzen voor huizen. 
Figuur 5.6

De gemiddelde WOZ-waarde van woningen per gemeente voor de provincie Overijssel, 2001

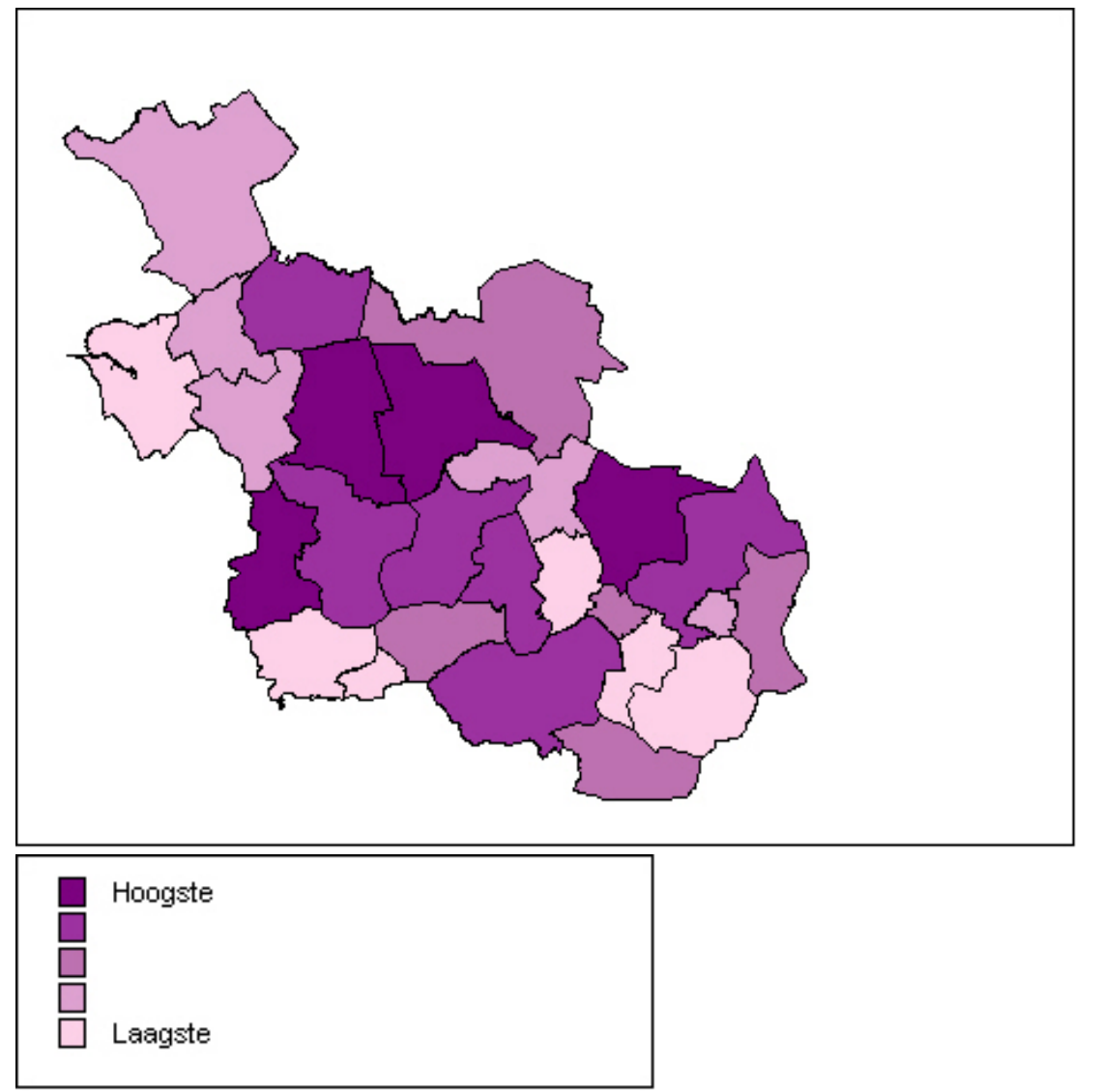

Bron: CBS

Het ligt voor de hand om ook te verwachten dat het werkloosheidspercentage in werkgelegenheidscentra lager is dan daarbuiten. Dit blijkt echter niet het geval te zijn. Voor Nederland als geheel blijkt dat in een stad met 100 meer werkenden per hectare, het werkloosheidspercentage gemiddeld $0,17 \%$ hoger ligt. De reden hiervoor is dat juist mensen met een lager inkomen de neiging hebben om in werkgelegenheidscentra te gaan wonen. Omdat het hierbij vaak gaat om personen met een lagere opleidingsachtergrond is de kans dat zij werkloos worden groter. Uit figuur 5.7 blijkt dat ook in Overijssel doorgaans gemeenten met veel werkgelegenheid ook gekenmerkt worden door een hogere werkloosheid. Een uitzondering hierop zijn de werkgelegenheidscentra Zwolle en Deventer. Deze gemeenten hebben ondanks een groot aantal werkenden een laag werkloosheidspercentage. ${ }^{47}$ Een verklaring hiervoor zou kunnen zijn dat het gemiddelde opleidingsniveau in deze

47. Het werkloosheidspercentage is hier gebaseerd op het aantal geregistreerde werklozen volgens het CBS, gemiddelde 1999-2001. Deze definitie wijkt af van de definitie van de werkloze beroepsbevolking (zie verklarende woordenlijst) van het CBS en de werkloosheidsdefinitie in de rayonrapportages van Etil. 
steden hoger ligt en er relatief veel HBO'ers en WO'ers zijn, waardoor het werkloosheidspercentage lager is.

Figuur 5.7

Het werkloosheidspercentage per gemeente voor de provincie Overijssel, 2001

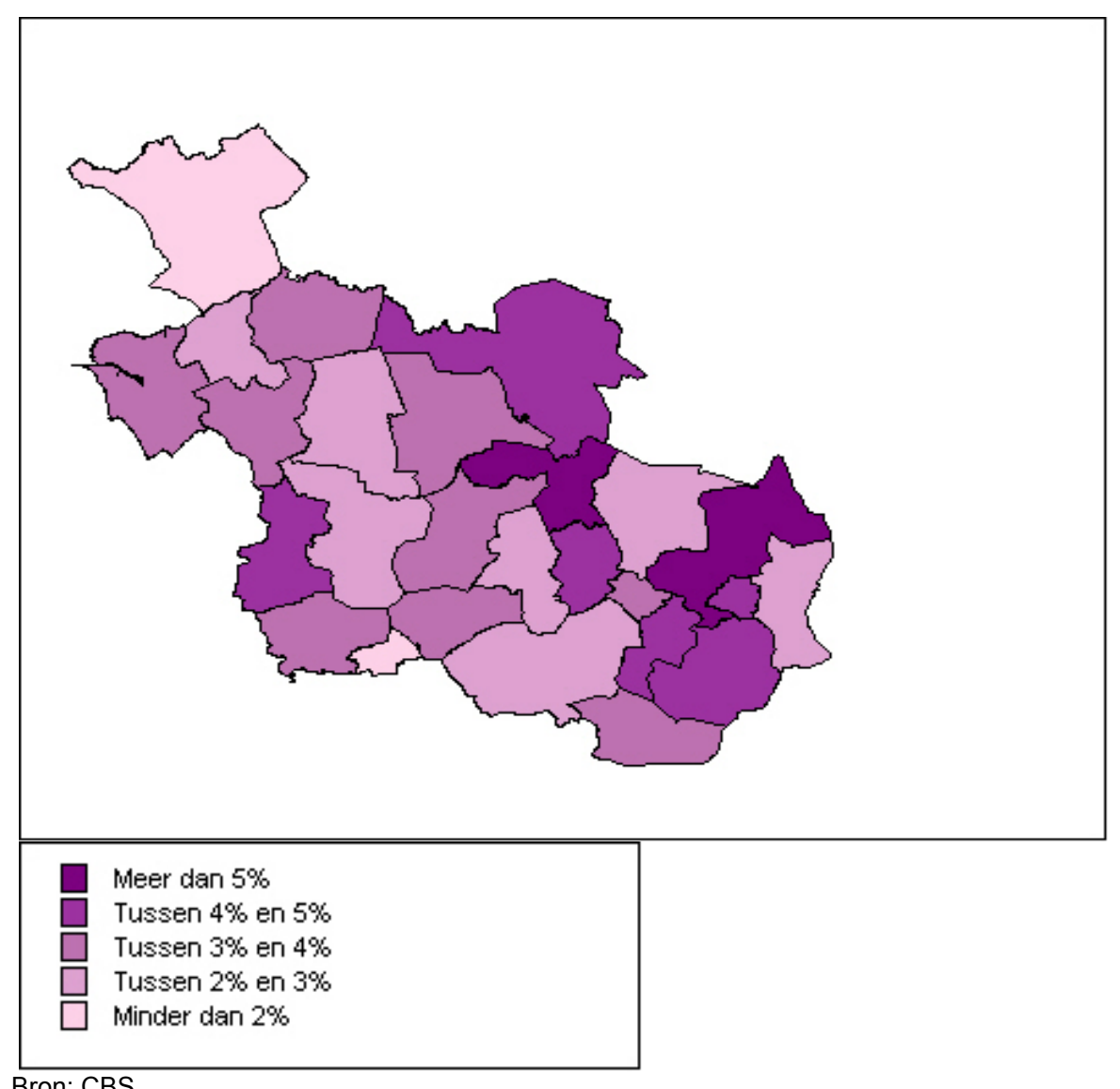

Bron: CBS

Voor een deel van het bronmateriaal dat gebruikt is in de figuren van dit hoofdstuk wordt verwezen naar de Appendix op de hierna volgende bladzijdes. 


\subsection{Appendix hoofdstuk 5: gebruikte indicatoren}

Tabel A.1

Indicatoren van werkenden per werkgemeente in de provincie Overijssel, 2001*

\begin{tabular}{|c|c|c|c|c|c|}
\hline \multirow[t]{2}{*}{ Werkgemeente } & \multicolumn{4}{|c|}{ Opleidingsniveau (in procenten) } & \multirow{2}{*}{$\begin{array}{l}\text { Gemiddeld } \\
\text { inkomen (in } \\
\text { euro's) }\end{array}$} \\
\hline & $\mathrm{BO}$ & VMBO & $\begin{array}{c}\text { MBO, } \\
\text { HAVO en } \\
\text { VWO }\end{array}$ & $\begin{array}{c}\mathrm{HBO} \text { en } \\
\text { wO }\end{array}$ & \\
\hline Almelo & 2 & 37 & 28 & 30 & 19170 \\
\hline Borne & 0 & 39 & 23 & 39 & 21.900 \\
\hline Dalfsen & 9 & 36 & 38 & 18 & 17.050 \\
\hline Denekamp & 0 & 29 & 54 & 18 & 17.410 \\
\hline Deventer & 1 & 31 & 32 & 34 & 19.360 \\
\hline Enschede & 4 & 27 & 35 & 32 & 18.560 \\
\hline Haaksbergen & 6 & 28 & 45 & 19 & 14.870 \\
\hline Hardenberg & 6 & 29 & 46 & 19 & 15.200 \\
\hline Hellendoorn & 3 & 58 & 29 & 8 & 18.590 \\
\hline Hengelo & 1 & 24 & 48 & 25 & 19.740 \\
\hline Kampen & 4 & 24 & 45 & 27 & 18.620 \\
\hline Losser & 0 & 46 & 27 & 27 & 17.210 \\
\hline Oldenzaal & 6 & 35 & 44 & 15 & 16.850 \\
\hline Olst & 0 & 17 & 52 & 22 & 23.860 \\
\hline Ommen & 15 & 55 & 19 & 9 & 15.890 \\
\hline Raalte & 3 & 60 & 27 & 10 & 13.770 \\
\hline Rijssen & 11 & 48 & 27 & 15 & 16.650 \\
\hline Staphorst & 0 & 30 & 39 & 26 & 15.860 \\
\hline Steenwijk & 3 & 33 & 43 & 19 & 18.470 \\
\hline Tubbergen & 0 & 58 & 19 & 10 & 14.850 \\
\hline Vriezenveen & 6 & 54 & 8 & 29 & 18.510 \\
\hline Wierden & 17 & 23 & 43 & 17 & 15.460 \\
\hline Zwolle & 3 & 17 & 42 & 36 & 19.300 \\
\hline Hof van Twente & 4 & 23 & 55 & 18 & 14.950 \\
\hline Zwartewaterland & 16 & 36 & 20 & 27 & 18.290 \\
\hline
\end{tabular}

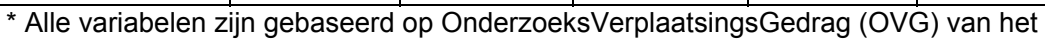
CBS, 2001. 


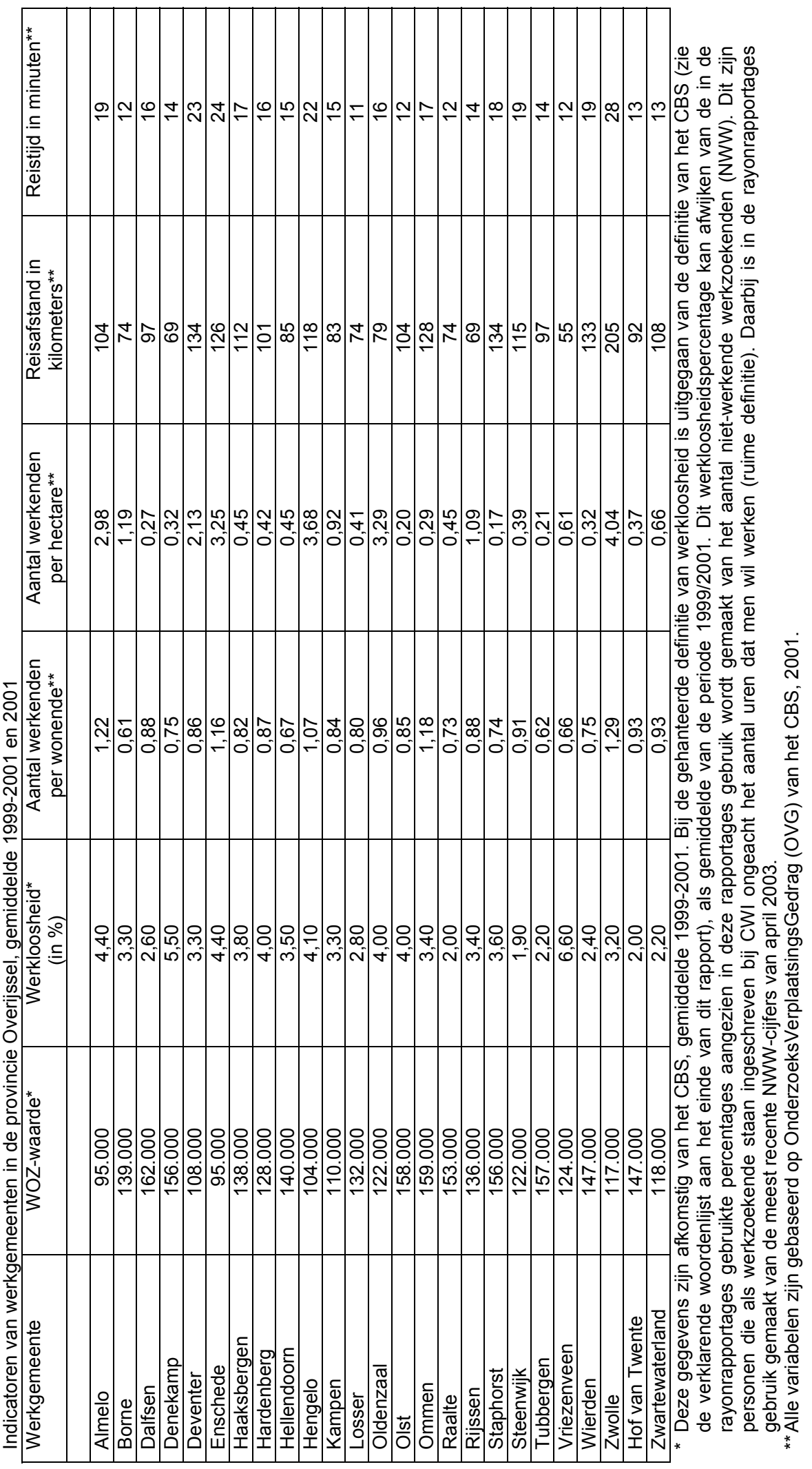





\section{Het onbenutte arbeidspotentieel in Overijssel}

Het onbenutte arbeidspotentieel van Overijssel omvat 191.500 personen die niet werken. ${ }^{48}$ Binnen het onbenutte arbeidspotentieel zijn alleen de 15.000 werklozen actief op zoek naar werk. Voor het verlichten van de knelpunten op de arbeidsmarkt zijn daarnaast de 19.000 niet-participerenden van belang die weliswaar niet actief zoeken naar werk maar wel beschikbaar zijn voor de arbeidsmarkt. De overige nietparticiperenden zijn niet beschikbaar voor de arbeidsmarkt, en vormen veruit de grootste groep binnen het onbenutte arbeidspotentieel.

Slechts $45 \%$ van het onbenutte arbeidspotentieel heeft een middelbare opleiding of hoger (een zgn. 'startkwalificatie'), tegenover $71 \%$ van de werkenden. Het gemiddelde opleidingsniveau van de werklozen is weliswaar lager dan van de werkenden maar hoger dan van de niet-participerenden. In tegenstelling tot de werkenden zijn de niet-participerenden in meerderheid vrouwen. Vooral nietwesterse allochtonen zijn vaak werkloos of niet-participerend. Zij hebben relatief vaak een lage opleidingsachtergrond. Het grootste gedeelte van de nietparticiperenden heeft geen intentie om te gaan werken en zal daarom zeer moeilijk kunnen worden gemotiveerd werk te aanvaarden.

Het onbenutte arbeidspotentieel is tussen 1993-1994 en 2001-2002 met ongeveer 44.000 personen in aantal gedaald. De opgaande conjunctuur en de voortdurende stijging van het opleidingsniveau hierbij een belangrijk rol gespeeld. Het aantal werklozen is in deze periode gehalveerd. Binnen het onbenutte arbeidspotentieel is het aantal personen dat aangeeft niet te willen werken absoluut gezien het meest gedaald. Juist daar waar de knelpunten in de personeelsvoorziening voor werkgevers het grootste zijn, namelijk op HBO- en WO-niveau, is het aantal werklozen en beschikbare niet-participerenden relatief het kleinst. Naast de opleidingsachtergrond speelt de relevante werkervaring vaak een nog belangrijkere rol voor werklozen en herintreders om te kunnen concurreren met schoolverlaters op de arbeidsmarkt.

Vrouwen, jongeren en laaggeschoolden treden relatief vaak uit vanwege de verzorging van de kinderen of arbeidsongeschiktheid. In zowel een krappe als een ruime arbeidsmarkt geldt echter dat hoe langer men niet op arbeidsmarkt participeert, des te minder goed het carrièreverloop zal zijn bij herintrede. Voor werklozen geldt dit effect alleen bij een ruime arbeidsmarkt. Zij lijken in een krappe arbeidsmarkt nauwelijks belemmerd te worden bij het vinden van een goede baan.

\subsection{Inleiding}

Beleidsmakers en de populaire media hebben een lage werkloosheid tot een symbool van economisch welzijn gemaakt. Als de werkloosheid echter te laag

48. De gegevens hebben betrekking op het gemiddelde van 2001 en 2002. 
wordt, ${ }^{49}$ krijgen werkgevers moeite met het vervullen van vacatures. Zij zullen over het algemeen dan minder selectief zijn bij het aannemen van personeel en tevens proberen om personen die niet tot de beroepsbevolking behoren, de niet-participerenden, te mobiliseren. Deze groep zoekt in tegenstelling tot de werklozen niet actief naar een baan. Hierbij moet gedacht worden aan bijvoorbeeld vrouwen die tijdelijk zijn teruggetreden van de arbeidsmarkt om de zorg van de kinderen op zich te nemen. Een deel van hen is mogelijk door betere arbeidsvoorwaarden te verleiden tot herintrede. Daarnaast zijn er niet-participerenden die niet zoeken naar betaald werk omdat ze denken toch moeilijk aan een baan te kunnen komen. Daarom worden de niet-participerenden naast de werklozen tot het onbenutte arbeidspotentieel gerekend. Als de werkloosheid weer oploopt kunnen werkgevers weer selectiever zijn ten aanzien van het personeel dat ze aannemen. Factoren als leeftijd, opleidingsachtergrond en arbeidsverleden spelen dan weer een grotere rol. Dit heeft dan waarschijnlijk ook consequenties voor de rekrutering onder het onbenutte arbeidspotentieel van werklozen en niet-participerenden.

In het eerste deel van dit hoofdstuk zal een overzicht gegeven worden van de samenstelling van het onbenutte arbeidspotentieel in Overijssel. De veranderingen van de grootte en de samenstelling van het onbenutte arbeidspotentieel over de tijd zullen worden bekeken en er zal worden nagegaan in welke mate het onbenutte arbeidspotentieel personeelstekorten in Overijssel kan verlichten.

In het tweede deel van het hoofdstuk zal worden ingegaan op de oorzaken van werkloosheid en non-participatie en de effecten van inactiviteit voor het verloop van de carrière als men weer een baan heeft gevonden. Met name zal worden onderzocht in hoeverre de inactiviteitsduur van een werkloze of herintreder leidt tot concessies bij het aanvaarden van een nieuwe baan. Zij kunnen zich met name bij een langere inactiviteitsduur genoodzaakt voelen om een baan op een lager niveau of in een andere richting dan gewenst te aanvaarden. In de analyse zal een onderscheid gemaakt worden naar het doen van concessies door werknemers ten tijde van een ruime ten opzichte van een krappe arbeidsmarkt. De verwachting hierbij is dat dit voor werknemers in een ruime arbeidsmarkt veel meer aan de orde is dan in een krappe arbeidsmarkt.

Achtereenvolgens zullen de volgende onderwerpen aan de orde komen:

- De grootte van het onbenutte arbeidspotentieel ten opzichte van de werkende beroepsbevolking in Overijssel, evenals de samenstelling van deze groep naar onder andere geslacht, leeftijd, beschikbaarheid, opleidingsachtergrond en etniciteit (§6.2);

- De ontwikkeling van het onbenutte arbeidspotentieel in Overijssel over de tijd ontwikkeld qua omvang en samenstelling (§6.3);

- De mogelijkheden voor het onbenutte arbeidspotentieel om de geprognostiseerde tekorten in het arbeidsaanbod te verlichten (\$6.4);

49. Hierbij kan worden gedacht aan een werkloosheid die onder het natuurlijke werkloosheidspercentage van ongeveer $5 \%$ daalt.

94 
- De belangrijkste oorzaken voor uittrede van mensen die werkloos of nietparticiperend zijn(\$6.5);

- Concessies door werkloosheid of non-participatie van potentiële werknemers bij het aanvaarden van een nieuwe baan, en het belang van de inactiviteitsduur hierbij (§6.5).

\subsection{Achtergrondkenmerken van het onbenutte arbeidspotentieel in Overijssel}

De volgende drie groepen kunnen binnen het onbenutte arbeidspotentieel onderscheiden worden: $:^{50}$

- Personen die op zoek zijn naar werk en beschikbaar zijn voor de arbeidsmarkt, de werklozen; ${ }^{51}$

- Personen die weliswaar geen werk zoeken maar wel beschikbaar zijn voor de arbeidsmarkt, de beschikbare niet-participerenden;

- Personen die niet beschikbaar zijn voor de arbeidsmarkt, de niet beschikbare niet-participerenden.

De niet-werkenden worden ingedeeld in deze drie groepen op basis van hun bereidheid om te werken. ${ }^{52}$ Indien men bijvoorbeeld werkloos is en naar een baan zoekt, wordt er een grotere bereidheid getoond om werk te aanvaarden dan wanneer men niet zoekt. Daarnaast geeft de beschikbaarheid voor de arbeidsmarkt, aan in welke mate iemand bereid is te werken. ${ }^{53}$

Ter stimulering van het onbenutte arbeidspotentieel om te gaan werken worden beleidsmatig een aantal doelgroepen onderscheiden, namelijk: vrouwen, jongeren, ouderen en allochtonen. ${ }^{54}$ In deze paragraaf zullen deze groepen bij het beschrijven van de achtergrondkenmerken van het onbenutte arbeidspotentieel nader worden toegelicht.

Tabel 6.1 geeft een beeld van een aantal achtergrondkenmerken van de nietwerkenden in Overijssel in vergelijking met de werkenden. Vrouwen zijn vooral vertegenwoordigd onder de niet-participerenden, terwijl de groep werkenden voor het

50. In de analyse is de totale populatie gelijk gesteld aan de potentiële beroepsbevolking, dat wil zeggen iedereen tussen 15 en 64 jaar, uitgezonderd scholieren en studenten.

51. Er wordt hier uitgegaan van werklozen volgens het begrip 'werkloze beroepsbevolking'. Het CBS beschouwt alleen personen als werkloos indien ze een baan van 12 uur of meer zoeken. Werklozen zijn volgens de definitie van de werkloze beroepsbevolking van het CBS de laatste vier weken op enigerlei wijze op zoek geweest naar een baan, en zijn in principe binnen twee weken beschikbaar voor een baan van 12 uur of meer. Zie de publicatie Enquête Beroepsbevolking 1999, CBS (Voorburg/Heerlen, 2000).

52. F. Cörvers en B. Golsteyn (2003) Changes in Women's Willingness to Work in a Tightening Labour Market: The Impact of Preferences, Wages and Individual Characteristics, ROARM-2003/5E, Maastricht.

53. Het CBS hanteert hierbij in principe een grens van twee weken, maar hanteert een ruimere grens van drie maanden als dit nodig is vanwege een opzegtermijn van de huidige werkkring (met een baan van minder dan 12 uur), het afronden van vrijwilligerswerk, het moeten regelen van kinderopvang of wegens ziekte of vakantie.

54. Zie bijvoorbeeld 'Participatie vraagt om werk! Nota arbeidsmarktbeleid 2003-2006 van de provincie Overijssel, augustus 2002.' 
grootste deel uit mannen bestaat. Uit de tabel blijkt verder dat niet-werkenden relatief vaak lager opgeleid zijn en dat een lagere beschikbaarheid voor de arbeidsmarkt gepaard gaat met een lager opleidingsniveau. Meer dan de helft van de nietparticiperenden heeft ten hoogste een VMBO opleiding, dat wil zeggen dat zij niet over een zogenaamde 'startkwalificatie' voor de arbeidsmarkt beschikken. Men spreekt van een startkwalificatie bij scholingsniveaus boven VMBO vanwege het betere carrièreperspectief van mensen met een dergelijk opleidingsniveau. Het percentage niet-beschikbaren zonder een zogenaamde startkwalificatie is bijna twee keer zo groot als het percentage werkenden zonder startkwalificatie. Ten slotte is $56 \%$ van degenen die niet beschikbaar voor de arbeidsmarkt zijn, ouder dan 50 jaar. In deze groep bevinden zich veel mannen die vervroegd zijn uitgetreden of met pensioen zijn. Dit illustreert dat non-participatie zich in belangrijke mate concentreert bij de vijftig-plussers en de (gehuwde) vrouwen. Voor de personen in de relatief grote groep van niet-beschikbaren in de leeftijdsklasse van 50 tot en met 64 jaar mag dan ook worden aangenomen dat ze, in combinatie met andere factoren als langdurige inactiviteit en geringe inspanningen voor het verwerven van een baan, slechts een kleine kans hebben op een betaalde baan.

Tabel 6.1

Werkenden, werklozen en niet-participerenden naar achtergrondkenmerken, Overijssel, gemiddelde 2001-2002

\begin{tabular}{|c|c|c|c|c|}
\hline \multirow[t]{2}{*}{ Kenmerk } & \multirow{2}{*}{$\begin{array}{r}\text { Werkend } \\
\%\end{array}$} & \multirow{2}{*}{$\begin{array}{r}\text { Werkloos } \\
\%\end{array}$} & \multicolumn{2}{|c|}{ Niet-participerend } \\
\hline & & & $\begin{array}{r}\text { Beschikbaar } \\
\%\end{array}$ & $\begin{array}{r}\text { Niet } \\
\text { beschikbaar } \\
\%\end{array}$ \\
\hline \multicolumn{5}{|l|}{ Geslacht } \\
\hline Man & 61,7 & 50,0 & 29,5 & 23,9 \\
\hline Vrouw & 38,3 & 50,0 & 70,5 & 76,1 \\
\hline \multicolumn{5}{|l|}{ Leeftijd } \\
\hline 15-29 jaar & 24,3 & 30,7 & 15,3 & 8,0 \\
\hline $30-49$ jaar & 55,4 & 54,6 & 48,8 & 36,6 \\
\hline 50-64 jaar & 20,3 & 14,7 & 35,9 & 55,5 \\
\hline \multicolumn{5}{|l|}{ Opleiding } \\
\hline BO-VMBO & 28,6 & 43,7 & 51,2 & 56,4 \\
\hline MBO-HAVO-VWO & 48,4 & 40,9 & 35,6 & 32,7 \\
\hline HBO-WO & 23,0 & 15,4 & 13,2 & 10,9 \\
\hline Totaal & 100 & 100 & 100 & 100 \\
\hline Aantal & 451.500 & 15.000 & 19.000 & 156.500 \\
\hline
\end{tabular}

Bron: CBS(EBB)/ROA

Onder de werklozen is de verdeling tussen mannen en vrouwen gelijk. In Nederland zijn er binnen de groep van werklozen juist meer vrouwen dan mannen. Dit zou kunnen betekenen dat in Overijssel vrouwen beter dan gemiddeld inzetbaar zijn in het arbeidsproces maar het kan ook een gevolg zijn van de reeds geleverde beleidsinspanningen gericht op de arbeidsdeelname van vrouwen. De overige percentages zijn in lijn met de Nederlandse cijfers. 
Tabel 6.2 laat zien dat allochtonen ${ }^{55}$ een belangrijke doelgroep voor beleid ter stimulering van het onbenutte arbeidspotentieel kunnen zijn. Autochtonen werken immers relatief meer en allochtonen zijn vaker werkloos of niet-participerend. Vooral bij de niet-westerse allochtonen behoort een relatief grote groep tot het onbenutte arbeidspotentieel. Gezien de leeftijdsverdeling van autochtonen en allochtonen zal het economische draagvlak voor de kosten van de vergrijzing steeds meer gezocht moeten worden bij de niet-westerse allochtonen. Deze groep heeft echter een veel lager opleidingsniveau dan de autochtonen en westerse allochtonen. Het percentage zonder startkwalificatie voor de arbeidsmarkt is bijna twee keer zo groot als het percentage zonder startkwalificatie onder de laatste twee groepen. Scholing zou daarom een speerpunt kunnen zijn om de niet-westerse allochtonen aantrekkelijk te maken voor werkgevers.

Tabel 6.2

Herkomst van de beroepsbevolking naar arbeidsmarktpositie, leeftijdsklasse en opleidingsniveau, Overijssel, gemiddelde 2001-2002

\begin{tabular}{lrrr}
\hline & Autochtoon & $\begin{array}{r}\text { Westerse } \\
\text { Allochtoon }\end{array}$ & $\begin{array}{r}\text { Niet-Westerse } \\
\text { Allochtoon }\end{array}$ \\
\hline Werkend & 72,2 & 66,0 & 51,3 \\
Werkloos & 1,9 & 4,1 & 6,0 \\
Niet-participerend, beschikbaar & 2,4 & 3,3 & 9,7 \\
Niet-participerend, niet-beschikbaar & 23,5 & 26,6 & 33,0 \\
Leeftijd & & & \\
15-29 jaar & 20,0 & 15,2 & 27,4 \\
30-49 jaar & 49,8 & 53,2 & 14,6 \\
50-64 jaar & 30,2 & 31,6 & \\
Opleiding & & & 63,9 \\
BO-VMBO & 34,1 & 37,3 & 10,7 \\
MBO-HAVO-VWO & 45,8 & 41,9 & 100 \\
HBO-WO & 20,1 & 20,8 & 43.500 \\
Totaal & 100 & 100 & \\
Aantal & 553.000 & 46.000 & \\
\end{tabular}

Bron: CBS(EBB)/ROA

Veranderingen in het onbenutte arbeidspotentieel

De omvang en samenstelling van het onbenutte arbeidspotentieel is aan veranderingen onderhevig. Dit kan in gang zijn gezet door zowel conjuncturele als structurele factoren. Wat betreft de conjuncturele factoren, kan gesteld worden dat over het algemeen de werkloosheid daalt bij een opgaande conjunctuur omdat werklozen sneller een baan vinden. Dit geldt in eerste instantie vooral voor werklozen die een goede opleiding met enige werkervaring combineren en niet al te lang werkloos zijn

55. Onder allochtonen worden personen verstaan van wie de vader en/of de moeder in het buitenland is geboren. Dit is volgens de nieuwe definitie van het CBS voor allochtonen naar herkomst in plaats van naar etniciteit. 
geweest. ${ }^{56} \mathrm{Na}$ een lange periode van grote krapte op de arbeidsmarkt, waarvan een jaar geleden nog sprake was, vormen zelfs de kansarme groepen op de arbeidsmarkt, zoals langdurig werklozen en ongeschoolden, een interessant arbeidspotentieel voor werkgevers om de knelpunten in de personeelsvoorziening te verlichten. Daarnaast is het denkbaar dat niet-participerenden eerder de arbeidsmarkt zullen betreden wanneer de arbeidsmarkt krapper is. Door de krappere arbeidsmarkt stijgen immers de kansen op een baan en verbeteren de arbeidsvoorwaarden, waardoor de baten van het zoeken naar werk en het aanvaarden van een betaalde baan, eerder opwegen tegen de kosten die gepaard gaan met bijvoorbeeld het solliciteren en het reizen naar het werk. Het is derhalve aannemelijk dat het onbenutte arbeidspotentieel gedurende de laatste jaren mede in omvang is verminderd door de arbeidsmarkt die steeds krapper werd. Dit betekent tevens dat de recente omslag in de conjunctuur bijdraagt aan de toename van het onbenutte arbeidspotentieel.

Tabel 6.3

Ontwikkeling van het Overijsselse onbenutte arbeidspotentieel

\begin{tabular}{|c|c|c|c|c|}
\hline \multirow[t]{2}{*}{ Categorie } & \multicolumn{2}{|c|}{ 1993-1994 } & \multicolumn{2}{|c|}{ 2001-2002 } \\
\hline & Aantal & $\%$ & Aantal & $\%$ \\
\hline $\begin{array}{l}\text { Werkloos } \\
\text { Beschikbaar }\end{array}$ & 30.500 & 13.0 & 15.000 & 7.8 \\
\hline Werk gezocht & 8.000 & 3.4 & 7.500 & 3.9 \\
\hline Geen werk gezocht & 16.000 & 6.8 & 11.500 & 6.0 \\
\hline \multicolumn{5}{|l|}{ Niet beschikbaar } \\
\hline Niet op korte termijn beschikbaar & 12.500 & 5.3 & 6.000 & 3.1 \\
\hline Wil geen betaald werk & 146.500 & 62.2 & 106.000 & 55.4 \\
\hline VUT of pensioen & 17.000 & 7.2 & 24.000 & 12.5 \\
\hline Arbeidsongeschikt, bereid om te werken & 5.000 & 2.1 & 21.500 & 11.2 \\
\hline Totaal onbenut arbeidspotentieel & 235.500 & 100 & 191.500 & 100.0 \\
\hline
\end{tabular}

Bron: CBS(EBB)/ROA

Tabel 6.3 laat de ontwikkeling van het aantal werklozen en niet-participerenden van Overijssel in de tijd zien. De niet-participerenden zijn opgesplitst in twee groepen: de beschikbare en de niet-beschikbare personen. In de tabel wordt de beschikbare groep verder opgesplitst in degenen die wel en geen werk gezocht hebben. ${ }^{57} \mathrm{De}$ groep die zich beschikbaar stelt maar niet naar werk gezocht heeft is veel groter dan de groep die wel gezocht heeft. De niet-beschikbare personen kunnen worden ingedeeld in vier groepen: personen die niet op korte termijn beschikbaar zijn, personen die geen werk willen, personen die vervroegd zijn uitgetreden of met pensioen zijn en arbeidsongeschikten die niet beschikbaar maar in principe wel bereid zijn om te werken. De groep die geen behoefte heeft aan betaald werk blijkt verreweg het grootst te zijn.

56. Zie bijv. W. Smits (2001), Wie willen werkgevers? Personeelsselectie in de Zorg, de Metaalindustrie en de IT, ROA-W-2001/2, Maastricht.

57. In de afgelopen 6 maanden werk gezocht, maar in de afgelopen 4 weken geen werk gezocht. 
In 1994 bereikte het werkloosheidspercentage in Nederland een piek. Tussen 1994 en 2001 verbeterde de situatie met grote sprongen. ${ }^{58}$ Uit de tabel blijkt dat, zoals verwacht kon worden, het onbenutte arbeidspotentieel de afgelopen jaren sterk is afgenomen van 235.500 in 1993-1994 naar 191.500 personen in 2001-2002. Daarbij is het aantal werklozen gehalveerd en het aantal mensen dat beschikbaar is voor de arbeidsmarkt aanzienlijk afgenomen. Van degenen die niet beschikbaar zijn voor de arbeidsmarkt is de groep die niet wil werken sterk afgenomen. De groep die niet op korte termijn beschikbaar is, is gehalveerd en de overige twee groepen zijn in omvang toegenomen. De toename van het aantal mensen dat met pensioen is, of in een VUT-regeling zit weerspiegelt de vergrijzing van de potentiële beroepsbevolking. Het aantal arbeidsongeschikten dat bereid is om te werken is meer dan verviervoudigd.

Tabel 6.4

Percentage van het onbenutte arbeidspotentieel met minimaal een middelbare opleiding, Overijssel

\begin{tabular}{lcc}
\hline Categorie & $\begin{array}{c}1993-1994 \\
\%\end{array}$ & $\begin{array}{c}2001-2002 \\
\%\end{array}$ \\
& & 56,3 \\
Werkloos & 52,6 & 48,8 \\
Beschikbaar & 40,9 & 43,7 \\
Niet Beschikbaar & 38,1 & 45,2 \\
Totaal onbenut arbeidspotentieel & 40,3 & 63,7 \\
Totaal potentiële beroepsbevolking & 57,2 & \\
\hline
\end{tabular}

Bron: CBS(EBB)/ROA

Zoals eerder al opgemerkt hangt de beschikbaarheid voor de arbeidsmarkt samen met het opleidingsniveau. Tabel 6.4 laat zien dat het aandeel van het onbenutte arbeidspotentieel dat een opleiding op minimaal middelbaar niveau heeft genoten tussen 1993-1994 en 2001-2002 is toegenomen met 4,9\%-punten. Echter, het opleidingsniveau van het onbenutte arbeidspotentieel is 1,6\%-punten minder toegenomen dan dat van de totale potentiële beroepsbevolking en het percentage mensen met minimaal een middelbare opleiding is bij het onbenutte arbeidspotentieel beduidend lager dan het gemiddelde voor de potentiële beroepsbevolking. Hieruit kan worden geconcludeerd dat wat betreft het opleidingsniveau de achterstand van het onbenutte arbeidspotentieel ten opzichte van de werkenden tussen 1993/94 en $2001 / 02$ is vergroot. Dit betekent dat het niet participeren op de arbeidsmarkt zich in toenemende mate concentreert bij degenen die niet beschikken over een startkwalificatie voor de arbeidsmarkt.

\subsection{Inzetbaarheid van het onbenutte arbeidspotentieel}

Voor het onbenutte arbeidspotentieel kan worden nagegaan of hun kwalificaties aansluiten op de arbeidsmarkt. In tabel 6.5 wordt per opleidingsniveau het percen-

58. In 2002 heeft er echter een omslag op de arbeidsmarkt plaatsgevonden. Het jaarlijkse werkloosheidspercentage (volgens de definitie van de werkloze beroepsbevolking van het CBS) is voor het eerst sinds 1994 weer licht gestegen. 
tage werklozen en beschikbare niet-participerenden en niet-beschikbare niet-participerenden weergegeven. Daarnaast wordt per opleidingsniveau een indicatie gegeven van de toekomstige knelpunten in de personeelsvoorziening.

Uit de tabel blijkt dat voor de grote groep lager opgeleiden, de vraag-aanbodverhoudingen op de arbeidsmarkt geen stimulans zijn om weer aan het werk te gaan. Naast de in het algemeen lagere bereidheid van niet-werkenden met een lagere opleiding om op de arbeidsmarkt te participeren, hebben de knelpunten op de arbeidsmarkt dus ook geen aanzuigende werking op deze mensen om weer te gaan werken. Bij de hogere opleidingen ( $H B O$ en WO) zullen de knelpunten in de personeelsvoorziening daarentegen naar verwachting groot zijn. Voor deze opleidingen mag derhalve verwacht worden dat de arbeidsmarkt een aanzuigende werking heeft op de niet-actieven. Met name voor deze groep is het dus van groot belang om adequaat in te spelen op de belemmeringen die men heeft om weer aan het werk te gaan.

Tabel 6.5

Arbeidsmarktpositie potentiële beroepsbevolking naar opleidingsniveau, Overijssel, gemiddelde 2001-2002

\begin{tabular}{|c|c|c|c|c|}
\hline Opleidingsniveau & $\begin{array}{c}\text { Werkloos of } \\
\text { beschikbaar } \\
\%\end{array}$ & $\begin{array}{c}\text { Niet } \\
\text { beschikbaar } \\
\%\end{array}$ & Aantal & $\begin{array}{l}\text { Knelpunten } \\
\text { personeels- } \\
\text { voorziening in } \\
2006 \text { (ITKP) }\end{array}$ \\
\hline Basisonderwijs & 8,9 & 46,9 & 75.000 & vrijwel geen \\
\hline VMBO (excl. VMBO theorie) & 5,6 & 33,7 & 118.000 & enige \\
\hline VMBO theorie & 7,6 & 32,6 & 40.000 & vrijwel geen \\
\hline HAVO/VWO & 6,2 & 21,1 & 23.500 & enige \\
\hline $\mathrm{MBO}$ & 4,4 & 17,8 & 259.500 & enige \\
\hline $\mathrm{HBO}$ & 4,3 & 14,9 & 96.500 & groot* \\
\hline WO & 2,4 & 9,3 & 28.962 & groot* $^{*}$ \\
\hline Totaal & 5,3 & 24,4 & 642.500 & \\
\hline
\end{tabular}

* Op basis van de verwachte landelijke vraag- en aanbodontwikkelingen. Bron: CBS(EBB)/ROA

In een recent onderzoek ${ }^{59}$ naar het selectiegedrag van werkgevers in de zorg-, IT-, en metaalsector wordt aangetoond dat werkgevers relevante werkervaring een belangrijk selectiecriterium vinden naast de genoten opleiding. Het beschikken over relevante werkervaring wordt door werkgevers in de IT- en metaalsector zelfs gezien als een belangrijker criterium dan de juiste opleidingsachtergrond. De reden hiervoor is dat in de IT-sector vaardigheden vereist zijn die door de voortdurende vernieuwingen snel verouderen en daardoor on the job moeten worden geleerd. In de zorgsector zijn daarentegen de formele opleidingseisen weer zeer belangrijk. In alle onderzochte sectoren blijkt dat herintreders met relevante werkervaring en de juiste opleidingsachtergrond een grotere kans hebben om te worden geselecteerd dan

59. W. Smits (2001), Wie willen werkgevers? Personeelsselectie in de Zorg, de Metaalindustrie en de IT, ROA-W-2001/2, Maastricht. 
schoolverlaters. Ten slotte blijkt uit het onderzoek dat werkgevers hun selectiecriteria ten tijde van hoogconjunctuur op verschillende manieren in de drie onderzochte sectoren aanpassen. Zo geldt dat in de IT- en metaalsector, in tegenstelling tot de zorgsector, tekorten veel minder snel leiden tot openstaande vacatures. In plaats daarvan wordt eerder personeel aangetrokken dat niet over alle vereiste kwalificaties beschikt.

Uit het bovenstaande volgt dat het arbeidsverleden van het onbenutte arbeidspotentieel een indicatie geeft van de mogelijkheden om opnieuw betaald werk te gaan verrichten. Uit tabel 6.6 blijkt dat $87 \%$ van het onbenutte arbeidspotentieel ooit werkervaring heeft opgedaan. ${ }^{60}$ Binnen het onbenutte arbeidspotentieel heeft de groep van niet-beschikbare personen relatief de meeste werkervaring. Dit is te verklaren doordat in deze groep veel gepensioneerden voorkomen.

Tabel 6.6

Werkervaring van werklozen en niet-participerenden, Nederland, 2001

\begin{tabular}{lrrrr}
\hline & Werkloos & Beschikbaar & $\begin{array}{r}\text { Niet- } \\
\text { beschikbaar } \\
\%\end{array}$ & Totaal \\
& $\%$ & $\%$ & 92 & 87 \\
\hline Ooit werk gehad & 81 & 75 & 8 & 13 \\
Nooit werk gehad & 19 & 25 & 100 & 100 \\
Totaal & 100 & 100 & &
\end{tabular}

Bron: CBS(SEP)

Tabel 6.7 geeft daarnaast aan hoeveel werkervaring werklozen en niet-participerenden per beleidsdoelgroep hebben. Ten opzichte van de mannen, hebben zoals verwacht vooral de jongeren veel minder werkervaring. Jongeren zijn vaak schoolverlaters die op zoek zijn naar hun eerste baan. Vrouwen en laag-geschoolden hebben ook minder werkervaring, maar toch veel meer dan de jongeren. Ouderen hebben zoals verwacht de meeste werkervaring.

Tabel 6.7

Werkervaring van werklozen en niet-participerenden naar beleidsdoelgroep, Nederland, 2001

\begin{tabular}{|c|c|c|c|c|c|c|}
\hline & Mannen & Vrouwen & $\begin{array}{r}\text { Laag- } \\
\text { geschoolden }\end{array}$ & $\begin{array}{l}\text { Jongeren } \\
<30 \text { jaar }\end{array}$ & $\begin{array}{l}\text { Ouderen } \\
>50 \text { jaar }\end{array}$ & Totaal \\
\hline Ooit werk gehad & 91 & 81 & 82 & 45 & 93 & 87 \\
\hline Nooit werk gehad & 9 & 19 & 18 & 55 & 7 & 13 \\
\hline Totaal & 100 & 100 & 100 & 100 & 100 & 100 \\
\hline
\end{tabular}

Bron: CBS (SEP)

60. Het gaat hier om een baan van tenminste 12 uur voor tenminste 3 maanden. 
Er moet worden opgemerkt dat de tabellen een inzicht geven in de algemene werkervaring van het onbenutte arbeidspotentieel. Dit hoeft echter niet in te houden dat hun concurrentiepositie goed is, immers alleen als er sprake is van relevante werkervaring kunnen herintreders in een sollicitatieprocedure goed concurreren met schoolverlaters met dezelfde opleiding.

\subsection{Oorzaken en gevolgen van werkloosheid en non-participatie}

\section{Oorzaken van inactiviteit}

Het inzicht in de factoren die leiden tot werkloosheid of non-participatie kan voor beleidsmakers en werkgevers van belang zijn om eventueel beleidsinitiatieven te ontplooien of het personeelsbeleid aan te passen.

Tabel 6.8

Reden van uittrede van de arbeidsmarkt van werklozen en niet-participerenden naar geslacht, opleidingsachtergrond en leeftijd, Nederland, 2001

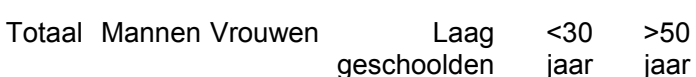

\begin{tabular}{|c|c|c|c|c|c|c|}
\hline Einde contract & 12,9 & 19,1 & 10,9 & 11,5 & 22,7 & 12,7 \\
\hline Huwelijk & 13,2 & 0,6 & 17,2 & 20,7 & 1,0 & 18,2 \\
\hline Geboortelverzorging kinderen & 30,3 & 1,8 & 39,3 & 27,9 & 20,8 & 14,5 \\
\hline Verhuizing door baan partner & 1,4 & - & 1,9 & 0,9 & - & 0,5 \\
\hline Studie & 1,8 & 3,2 & 1,3 & 0,7 & 17,8 & 0,3 \\
\hline Eigen ziekte of handicap & 14,8 & 24,5 & 11,7 & 16,9 & 12,9 & 16,5 \\
\hline Pensioen/VUT & 13,5 & 41,6 & 4,7 & 9,1 & - & 26,2 \\
\hline Andere reden & 12,1 & 9,1 & 13,0 & 12,4 & 24,8 & 11,0 \\
\hline Totaal & 100 & 100 & 100 & 100 & 100 & 100 \\
\hline
\end{tabular}

Bron: CBS(SEP)

In tabel 6.8 staat voor degenen die ooit een baan gehad hebben maar nu niet werken de reden die zij hadden om uit te treden. In de tabel is een opsplitsing gemaakt naar de bovengenoemde doelgroepen van arbeidsmarktbeleid. ${ }^{61}$ Ter vergelijking zijn ook gegevens opgenomen van uitgetreden mannen. Vrouwen blijken zoals verwacht veel meer dan mannen uit te treden vanwege huwelijk of zorgtaken. Ook voor jongeren en laaggeschoolden is de hoofdreden om uit te treden het verzorgen van kinderen. Hieruit blijkt het grote belang van voldoende faciliteiten voor kinderopvang om de arbeidsmarktparticipatie van drie van de vijf doelgroepen te vergroten. $\mathrm{Na}$ het verzorgen van kinderen is arbeidsongeschiktheid of ziekte de belangrijkste reden om te stoppen met werken. Dit laatste geldt in nog sterkere mate voor mannen. Voor mannen in het algemeen en voor ouderen blijkt ook dat vervroegde uittreding of pensioen een belangrijke reden voor het verlaten van de arbeidsmarkt zijn. Derhalve kan beleid gericht op het terugdringen van vervroegde uittreding een belangrijke rol te spelen bij het vergroten van de arbeidsparticipatie.

61. Het was hierbij niet mogelijk de herkomst van de persoon te onderscheiden. Derhalve is er geen onderscheid gemaakt naar autochtonen en allochtonen. 102 


\section{Gevolgen van inactiviteit}

Inactiviteit heeft gevolgen voor onder andere de financiële positie en het sociale netwerk (met collega's) van mensen. Daarnaast kan inactief zijn leiden tot kwalificatieveroudering. Onder kwalificatieveroudering wordt zowel technische veroudering als economische veroudering verstaan. Bij technische veroudering gaan er daadwerkelijk kwalificaties verloren die iemand voorheen bezat. Dit kan zowel komen door slijtage, waarbij men door het ouder worden of door slechte arbeidsomstandigheden (veel tillen, lawaai, stank, e.d.) de oorspronkelijke functie niet langer kan uitvoeren. Daarnaast kunnen door atrofie bijvoorbeeld bij langdurige uittrede van de arbeidsmarkt, vaardigheden gedurende een lange tijd niet gebruikt worden. Deze laatste vorm van kwalificatieveroudering is in de context van deze paragraaf van belang. Bij economische veroudering van menselijk kapitaal verliest iemand niet de kwalificaties die hij of zij had, maar verliezen deze kwalificaties hun marktwaarde. Hierbij kan gedacht worden aan technologische vernieuwingen in bepaalde banen waardoor bestaande vaardigheden niet meer toereikend zijn, of bijvoorbeeld de afname van de werkgelegenheid in bepaalde sectoren waardoor er geen vraag meer bestaat naar deze vaardigheden op de arbeidsmarkt. ${ }^{62}$ Ook deze vorm van kwalificatieveroudering kan bij werklozen of niet-participerenden optreden. Dit verlies van vaardigheden kan bij aanvaarding van een nieuwe baan een rol spelen als bijvoorbeeld blijkt dat de nieuwe baan slechter is dan de baan die men voor de periode van inactiviteit had.

De vraag die in deze paragraaf wordt behandeld is of inactiviteit leidt tot een minder goed carrièreverloop. ${ }^{63}$ Omdat naar verwachting werkgevers meer bereid zijn concessies te doen bij het aannemen van nieuw personeel in een krappe dan in een ruime arbeidsmarkt, zal het effect van inactiviteit op een vervolgbaan naar verwachting relatief sterk zijn in een ruimere arbeidsmarkt. Om dit te laten zien zal het effect van inactiviteit op de vervolgbaan worden bekeken tussen 1994 en 2001. In deze periode is de arbeidsmarkt omslagen van ruim naar krap.

Aan respondenten van het Sociaal-Economisch Panel is gevraagd hun huidige baan te evalueren ten opzichte van hun vorige baan. Zij hebben hierbij de keuze uit "slechter, hetzelfde of beter". ${ }^{4}$ Ook is er gevraagd of zij een baan hadden voor hun

62. ROA (2001), Werkgelegenheid en Scholing 2001, ROA-R-2002/7, Maastricht. Zie ook bijvoorbeeld: A. de Grip, J. van Loo and K. Mayhew (Eds.), The Economics of Skills Obsolescence, Research in Labor Economics, Vol. 21, JAI Press, 2002.

63. Het krijgen van een mindere vervolgbaan wordt vaak onderbenutting genoemd. In de context van inactiviteit kan onderbenutting echter een misplaatste term zijn omdat bij inactiviteit een verlies van vaardigheden optreedt en de nieuwe baan, hoewel lager ten opzichte van de vorige baan, goed kan passen bij de verouderde kwalificaties van de herintreder.

64. Deze subjectieve maatstaf kan als nadeel hebben dat er psychologische processen kunnen spelen waardoor de resultaten vertekend worden. Zo kan het meespelen dat personen niet graag toegeven een slechtere baan te hebben gekregen. Aan objectieve resultaten, zoals een vergelijking van het salaris in de huidige ten opzichte van de vorige baan, kunnen echter ook nadelen kleven omdat er arbitraire grenzen moeten worden gesteld. Daarnaast kan het zijn dat men niet verandert van baan vanwege salarisredenen maar vanwege de betere kinderopvangvoorzieningen, mogelijkheid tot parttime werken, etc. Het salaris als enige maatstaf nemen leidt dan tot een overschatting van het probleem. 
huidige werkkring en of zij werkloos of niet-participerend waren. Tabel $6.9 \mathrm{geeft}$ aan dat de meeste personen een betere baan krijgen. Dit kan verklaard worden doordat men ouder is bij het krijgen van een nieuwe baan en dus beter weet wat men wil of door ervaring een hoger loon krijgt. Daarnaast is er mogelijk sprake van een overschatting van de waarde de nieuwe baan. Men zal immers niet gemakkelijk erkennen een slechtere baan te hebben gekregen.

Tabel 6.9

De invloed van werkloosheid in een ruime en een krappe arbeidsmarkt op de waardering van de huidige baan ten opzichte van vorige baan, Nederland

\begin{tabular}{lccrr}
\hline $\begin{array}{l}\text { Vergelijking huidige } \\
\text { en vorige baan }\end{array}$ & $\begin{array}{c}1994 \\
\text { Baan- } \\
\text { baan }\end{array}$ & $\begin{array}{r}\text { Werkloosheid- } \\
\text { baan }\end{array}$ & $\begin{array}{r}2000 \\
\text { Baan- } \\
\text { baan }\end{array}$ & $\begin{array}{r}\text { Werkloosheid- } \\
\text { baan }\end{array}$ \\
\hline Slechter & 8,0 & 12,8 & 5,6 & 6,2 \\
Hetzelfde & 17,5 & 18,8 & 15,8 & 15,3 \\
Beter & 74,5 & 68,4 & 78,5 & 78,6 \\
Totaal & 100 & 100 & 100 & 100 \\
\hline Bron: CBS(SEP) & & & &
\end{tabular}

Uit tabel 6.9 blijkt dat de verschillen in waardering van baanwisselaars (baan-baan) en werklozen die een baan accepteren (werkloosheid-baan) in een ruime arbeidsmarkt veel groter zijn dan in een krappe arbeidsmarkt. Werklozen moeten in een ruime arbeidsmarkt (significant) meer concessies doen bij het krijgen van een baan ten opzichte van baanwisselaars die een baan hadden voor de huidige werkkring.

Het belangrijkste verschil ontstaat als men een slechtere baan moet accepteren. $12,8 \%$ van de werklozen moet in 1994 een slechtere baan accepteren ten opzichte van $8,0 \%$ van de baanwisselaars. Het verschil tussen deze percentages, $4,8 \%$, is een indicatie hoeveel moeilijker werklozen het hebben dan baanwisselaars bij het vinden van een baan in een ruime arbeidsmarkt. In figuur 6.1 zijn de percentages van baanwisselaars en werklozen die een minder goede nieuwe baan krijgen ten opzichte van hun laatste baan vanaf 1994 weergegeven. Het eveneens weergegeven werkloosheidspercentage geeft een indicatie van de krapte op de arbeidsmarkt. Uit de figuur blijkt dat bij de baanwisselaars het percentage personen dat de laatste baan als slechter dan de vorige baan waardeert licht is gedaald. Vooral tussen 1994 en 1995 en na 1999 is het percentage relatief sterk gedaald. Bij de werklozen die een baan accepteren is de daling echter veel sterker. Dit betekent dat de verbetering van de algehele arbeidsmarktsituatie het effect van werkloosheid op de waardering van de nieuwe baan heeft verminderd. Hieruit kan worden geconcludeerd dat de waardering van een nieuwe baan door baanwisselaars afhankelijk is van de conjunctuur, maar dat de kansen op de arbeidsmarkt van werklozen veel gevoeliger zijn voor conjunctuurschommelingen. 
Figuur 6.1

Percentage personen dat een baan lager waardeert dan de vorige baan, baan-baan wisselaars en werkloosheid-baanvinders, Nederland, 1994-2001

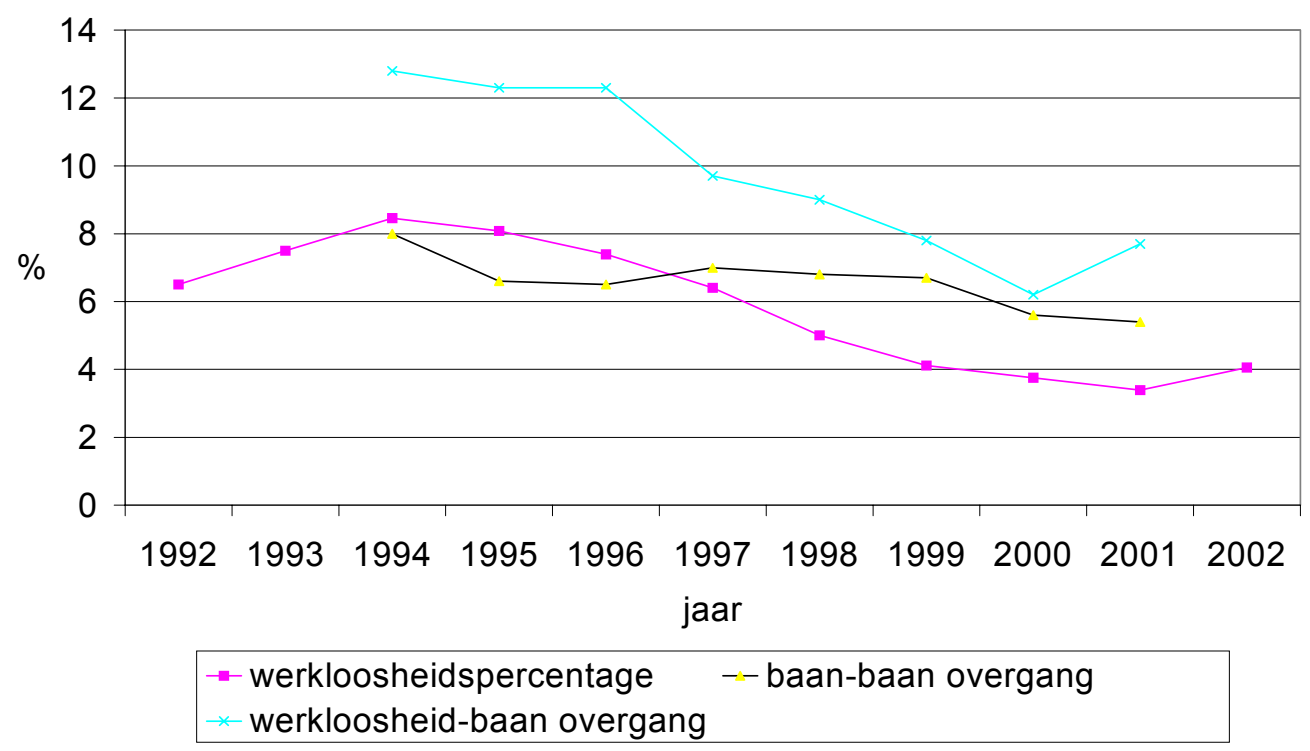

Bron: CBS (SEP) / ROA

Naast werkloosheid als zodanig, is ook de werkloosheidsduur van belang. Immers, hoe langer men niet werkt, des te meer vaardigheden men verliest en hoe slechter de vervolgbaan daardoor zal zijn. Uit analyse blijkt dat de duur van de werkloosheid in een ruime arbeidsmarkt een negatief effect heeft op het niveau van de vervolgbaan, terwijl dit in een krappe arbeidsmarkt niet het geval is. ${ }^{65}$ Dit betekent dat werklozen niet alleen meer concessies moeten doen bij een verslechtering van de algehele arbeidsmarktsituatie ten opzichte van degenen die al een baan hebben en van baan wisselen, maar ook dat de duur van de werkloosheid tot meer concessies leidt voor werklozen. Een gevolg hiervan is dat langdurig werklozen meer dan kortdurig werklozen genoodzaakt zijn om concessies te doen bij het zoeken naar een baan.

Werklozen kunnen echter ook besluiten om niet meer te zoeken naar een baan. Men behoort dan tot de niet-participerenden. Een tweede analyse toont aan dat de inactiviteitsduur bij non-participatie een (significant) negatief effect heeft op de waardering van de huidige baan ten opzichte van de vorige. In tegenstelling tot het effect van de werkloosheidsduur, geldt dit zowel in een ruime als in een krappe arbeidsmarkt. ${ }^{66}$ Dit betekent dat zelfs bij een krappe arbeidsmarkt de herintreders die

65. Gecontroleerd voor geslacht, leeftijd en opleidingsniveau werd er in 1994 en 2000 een significant negatief effect gevonden van het aantal maanden werkloosheid op de evaluatie van de vervolgbaan.

66. Gecontroleerd voor geslacht, leeftijd en opleidingsniveau werd er in 1994 en 2000 een significant negatief effect gevonden van het aantal jaren non-participatie op de subjectieve waardering van de vervolgbaan. 
geruime tijd niet op de arbeidsmarkt hebben geparticipeerd meer dan gemiddeld moeite zullen hebben om de gewenste baan te vinden.

Samenvattend, inactiviteit heeft een grote invloed op het verloop van de carrière, met name als het aanbod de vraag naar arbeidskrachten overtreft. Dit geldt vooral voor de niet-participerenden, maar ook voor de werklozen. In een krappe arbeidsmarkt wordt door de grote vraag naar personeel het verlies aan vaardigheden ten gevolge van een langere werkloosheidsduur eerder door werkgevers voor lief genomen. 


\section{Verklarende woordenlijst}

\section{Arbeidsmarktinstroom van schoolverlaters}

Het aanbod van nieuwe arbeidskrachten op de arbeidsmarkt, zoals deze is bepaald door de verwachte uitstroom van schoolverlaters uit het initiële dagonderwijs, de schoolverlaters van het deeltijdonderwijs, het niet-reguliere voltijdonderwijs en de beroepsgerichte volwasseneneducatie. Voor deze groep nieuwe arbeidskrachten wordt in dit rapport soms ook de alternatieve term 'nieuwkomers op de arbeidsmarkt' gebruikt.

\section{Arbeidsmarktkrapte}

Het begrip arbeidsmarktkrapte dat in deze rapportage gehanteerd wordt, is gedefinieerd als de verhouding tussen het aantal openstaande vacatures en het aantal niet-werkende werkzoekenden in bemiddelingsfase 1 per arbeidsmarktsegment. Wanneer de indicator voor de arbeidsmarktkrapte kleiner is dan één, is er sprake van een aanbodoverschot op het betreffende segment. Wanneer de indicator voor de arbeidsmarktkrapte groter is dan één, is er sprake van een tekort aan niet-werkende werkzoekenden in het betreffende segment. Dit tekort kan twee oorzaken hebben: wanneer het aanbod getalsmatig tekortschiet is er sprake van een kwantitatief probleem. De knelpuntindicator (zie hier beneden) zal dan groter zijn dan één. Wanneer het probleem vooral gelegen is in het feit dat het percentage niet-werkende werkzoekenden in fase 1 laag is, is dit tekort vooral een kwalitatief aansluitingsprobleem dat zich zal manifesteren in een knelpuntindicator kleiner dan één. Aangezien werkzoekenden niet naar bedrijfssector ingedeeld kunnen worden, kan deze maatstaf niet gebruikt worden om de arbeidsmarktkrapte naar bedrijfssector te berekenen. De arbeidsmarktkrapte naar bedrijfssector is daarom gedefinieerd als het gewogen gemiddelde van de arbeidsmarktkrapte naar beroepsgroep. De wegingsfactor is daarbij gebaseerd op het aandeel van de betreffende beroepsgroep in het totale aantal openstaande vacatures in die bedrijfssector. Hoe hoger de arbeidsmarktkrapte in een bedrijfssector, hoe groter de rekruteringsproblemen.

\section{Baanopeningen}

De baanopeningen representeren de totale vraag naar nieuwkomers op de arbeidsmarkt, zoals deze is bepaald door de werkgelegenheidsgroei (positieve uitbreidingsvraag) en de (netto) vervangingsvraag.

\section{Bedrijfssector}

Alle voorkomende bedrijven zijn ingedeeld in een aantal clusters. De in deze rapportage gepresenteerde informatie is - met uitzondering van de totale werkgelegenheid - verbijzonderd naar 13 bedrijfssectoren. Deze komen overeen met de door het CPB gehanteerde bedrijfssectorindeling. 


\section{Bemiddelingsfase}

Het begrip bemiddelingsfase dat in deze rapportage wordt gehanteerd, is gebaseerd op de indeling zoals die door het Centrum van Werk en Inkomen (CWI) wordt gehanteerd. Een hogere bemiddelingsfase impliceert een grotere afstand tot de arbeidsmarkt:

- Fase 1: De werkzoekende voor wie arbeidsmarktinstrumenten beschikbaar zijn gericht op directe bemiddeling of terugkeer naar de arbeidsmarkt.

- Fase 2: De werkzoekende voor wie arbeidsmarktinstrumenten beschikbaar zijn gericht op een zodanige verbetering van de kans op werk, dat hij/zij binnen een tijdsbestek van maximaal een jaar als werkzoekende bemiddelbaar is op de arbeidsmarkt.

- Fase 3: De werkzoekende voor wie arbeidsmarktinstrumenten beschikbaar zijn gericht op een zodanige verbetering van de kans op werk, dat hij/zij binnen een tijdsbestek van meer dan een jaar als werkzoekende bemiddelbaar is op de arbeidsmarkt.

- Fase 4: De werkzoekende die tengevolge van zware persoonlijke werkbelemmeringen is aangewezen op hulp en zorg die gericht is op een zodanige verbetering van zijn/haar eigen positie dat eerst op termijn arbeidsmarktinstrumenten inzetbaar zijn gericht op de verbetering van zijn/haar kans op werk.

\section{Beroepsgroep, Beroepsklasse, Beroepssegment}

Alle voorkomende beroepen zijn ingedeeld in een aantal clusters. In deze rapportage en de bijbehorende Statistische Bijlage wordt afwisselend gebruik gemaakt van de indeling in 127 beroepsgroepen, 11 beroepssectoren en 43 beroepssegmenten.

\section{Bijscholing}

Er is sprake van bijscholing wanneer een scholingstraject de opleidingsachtergrond van een werkzoekende niet verandert.

\section{Conjunctuurgevoeligheid}

De conjunctuurgevoeligheid van de werkgelegenheid heeft betrekking op de mate waarin de werkgelegenheid voor mensen met een bepaalde opleidingsachtergrond gevoelig is voor veranderingen van de economische situatie. Deze indicator geeft daarmee de mate van werkzekerheid aan. De conjunctuurgevoeligheid wordt bepaald door de sectorale werkgelegenheidsfluctuaties in het verleden te relateren aan de mate waarin een opleidingstype momenteel in de verschillende bedrijfssectoren is vertegenwoordigd. Hierbij wordt rekening gehouden met het feit dat niet ieder opleidingstype even sterk mee fluctueert met de werkgelegenheidsschommelingen van de bedrijfssector.

\section{Deeltijdarbeid}

Deeltijdarbeid betreft personen die hoogstens 32 uur maar minstens 12 uur per week werkzaam zijn.

\section{Eigen vakrichting}

Een indicatie van de mate waarin arbeidskrachten werkzaam zijn in een functie die niet goed aansluit bij de gevolge opleidingsrichting. De mate waarin schoolverlaters 
buiten de eigen vakrichting werkzaam zijn wordt in dit rapport vastgesteld door de schoolverlaters zelf te laten aangeven in hoeverre voor de door hen uitgeoefende functie de eigen of een verwante opleidingsrichting vereist is.

\section{Flexibel werk}

Van flexibel werk is sprake bij uitzendkrachten, oproepkrachten, invalkrachten, contracten zonder een vast aantal arbeidsuren en indien geen vast dienstverband is overeengekomen.

\section{Frictiewerkloosheid}

Frictiewerkloosheid is de min of meer onvermijdbare werkloosheid, die het gevolg is van het feit dat het bij het veranderen van werk, of het zoeken van een eerste baan, vaak enige tijd duurt voordat men na sollicitatie wordt aangenomen.

\section{Knelpuntindicator}

Het begrip knelpuntindicator dat in deze rapportage wordt gehanteerd is gedefinieerd als de verhouding tussen het aantal openstaande vacatures dat niet door nietwerkende werkzoekenden in bemiddelingsfase 1 vervuld kan worden en het aantal niet-werkende werkzoekenden in bemiddelingsfase 2 en 3 . Hoe hoger de knelpuntindicator, hoe minder niet-werkende werkzoekenden met een grotere afstand tot de arbeidsmarkt er beschikbaar zijn voor de openstaande vacatures die niet door direct bemiddelbare werkzoekenden vervuld kunnen worden. Dit impliceert tevens dat een hoge knelpuntindicator een werkzoekende in het betreffende segment de mogelijkheid biedt via bijscholing de kansen op een baan te vergroten. Wanneer het aantal niet-werkende werkzoekenden in fase 1 het aantal openstaande vacatures overtreft, is de knelpuntindicator gelijk aan 0 . Er is dan geen sprake van een tekort aan gekwalificeerd aanbod. Het aantal banen schiet juist tekort om alle direct inzetbare werkzoekenden aan werk te helpen.

\section{Langdurig werkzoekende}

Het begrip langdurig werkzoekende dat in deze rapportage wordt gehanteerd, is gedefinieerd als een werkzoekende die langer dan een jaar ingeschreven is bij het Centrum voor Werk en Inkomen (CWI). Opgemerkt dient te worden dat dit niet noodzakelijkerwijs impliceert dat de betreffende werkzoekende tijdens de periode niet gewerkt heeft.

\section{Langdurig openstaande vacature}

Het begrip langdurig openstaande vacature dat in deze rapportage wordt gehanteerd, is gedefinieerd als een vacature die langer dan drie maanden openstaat.

\section{Omscholing}

Er is sprake van omscholing wanneer het scholingstraject de opleidingsachtergrond van een werkzoekende verandert. Omscholing kan zowel niveauverhogend als richtingveranderend van aard zijn. 


\section{Onderbenutting}

Onderbenutting is een indicatie van de mate waarin arbeidskrachten werkzaam zijn op een functieniveau dat lager is dan hun opleidingsniveau. De onderbenutting van schoolverlaters wordt in dit rapport vastgesteld door de schoolverlaters zelf te laten aangeven welk opleidingsniveau vereist is voor de door hen uitgeoefende functie.

\section{Opleidingssector, Opleidingstype}

Alle voorkomende opleidingen zijn samengevoegd tot een aantal clusters. In de prognosemethodiek en in de bij dit rapport verschenen Statistische Bijlage wordt voornamelijk uitgegaan van 113 opleidingstypen. In het rapport wordt in de meeste gevallen echter een indeling naar 21 opleidingssectoren gehanteerd.

\section{Potentiële beroepsbevolking}

De potentiële beroepsbevolking omvat de werkenden, de werklozen en de nietparticiperenden. ledereen die tussen de 15 en de 64 jaar oud is en geen voltijdopleiding volgt, wordt tot de potentiële beroepsbevolking gerekend. Als men meer dan 12 uur per week werkt, wordt men tot de werkzame beroepsbevolking gerekend. Werkt men niet of minder dan 12 uur, maar wil men wel minstens 12 uur per week betaalde arbeid verrichten, dan behoort men tot de werkloze beroepsbevolking. Werkt men niet of minder dan 12 uur, en is men niet op zoek naar betaalde arbeid voor minstens 12 uur per week, dan behoort men tot de niet-participerende beroepsbevolking (de zgn. 'stille reserve').

\section{Toekomstig arbeidsmarktperspectief}

Het toekomstig arbeidsmarktperspectief geeft de verhouding tussen aanbod en vraag in de prognoseperiode voor een opleidingstype weer. Als het arbeidsmarktperspectief slecht is, betekent dit dat er in het (de) komende ja(a)r(en) veel meer aanbod van nieuwkomers is dan er baanopeningen zijn. Hierdoor zal de arbeidsmarktpositie gaan verslechteren. Deze verslechtering kan een hogere werkloosheid betekenen, maar door aanpassingsprocessen op de arbeidsmarkt kan dit ook leiden tot het moeten aanvaarden van banen op een lager niveau, een lagere beloning en meer tijdelijke contracten. Omgekeerd zal een goed perspectief tot een grotere kans op werk, maar ook tot een verbeterde positie op andere punten leiden. Het toekomstig arbeidsmarktperspectief per opleidingstype wordt bepaald door middel van de Indicator Toekomstige Arbeidsmarktsituatie (ITA), die is gedefinieerd als de verhouding tussen enerzijds de verwachte instroom van schoolverlaters en anderzijds de verwachte baanopeningen. Naarmate de waarde van de indicator hoger is, is het perspectief slechter. Merk overigens op dat een hogere ITA een slechtere (toekomstige) arbeidsmarktsituatie impliceert, terwijl een hogere arbeidsmarktkrapte een indicatie is voor een betere (huidige) arbeidsmarktpositie van een opleidingstype.

\section{Toekomstige knelpunten in de Personeelsvoorziening}

Als de toekomstige vraag naar werkenden met een bepaalde opleidingsachtergrond groter is dan het aanbod, kunnen knelpunten in de personeelsvoorziening verwacht worden. Vergelijkbaar met de Indicator Toekomstige Arbeidsmarktsituatie (ITA, zie hierboven) geeft de Indicator Toekomstige Knelpunten in de Personeelsvoorziening (ITKP) deze vraag-aanbod-spanning aan. Het verschil met de ITA is dat bij de ITKP 
de uitstroom van werkenden als gevolg van een krimpende werkgelegenheid is meegerekend in de vraag, omdat verwacht mag worden dat bij knelpunten in de personeelsvoorziening deze (gedwongen) uitstroom kan worden afgeremd of elders werk zou kunnen vinden. Naarmate de waarde van de indicator lager is, zijn de verwachte knelpunten groter. Analoog geeft de Indicator Toekomstige Knelpunten in de personeelsvoorziening naar Beroep (ITKB) de knelpunten naar beroepsgroep weer.

\section{Toekomstige Knelpunten in de personeelsvoorziening naar Beroep}

Voor het vaststellen van de verwachte knelpunten in de personeelsvoorziening naar beroep gebruiken we de Indicator Toekomstige Knelpunten in de personeelsvoorziening naar Beroep (ITKB). Deze indicator geeft aan in welke mate werkgevers problemen ondervinden bij het aantrekken van geschikt personeel. Naarmate de waarde van de ITKB lager is, zijn er meer knelpunten te verwachten. Wanneer het aanbod kleiner is dan de vraag, dan is de ITKB kleiner dan 1,00. De knelpunten in de personeelsvoorziening worden dan als groot getypeerd. Als de waarde van de indicator zelfs kleiner is dan 0,85 dan wordt gesproken van zeer grote knelpunten. Wanneer de ITKB daarentegen tussen 1,00 en 1,05 ligt, dan wordt gesproken van enige knelpunten. Bij een hogere waarde van de ITKB is sprake van vrijwel geen knelpunten, en mocht de ITKB zelfs groter zijn dan 1,15, dan is er sprake van geen knelpunten in de personeelsvoorziening.

\section{Uitbreidingsvraag}

De uitbreidingsvraag is de vraag naar nieuwe arbeidskrachten die ontstaat door groei van de werkgelegenheid. Als er sprake is van een werkgelegenheidsdaling, is de uitbreidingsvraag negatief.

\section{Uitwijkmogelijkheden}

Dit is de mate waarin arbeidskrachten met een bepaalde opleidingsachtergrond terecht kunnen komen in andere beroepsgroepen op een aansluitend of hoger functieniveau. Deze maatstaf geeft daarmee aan in hoeverre arbeidskrachten afhankelijk zijn van de arbeidsmarktsituatie in een bepaald beroep. De uitwijkmogelijkheden worden bepaald met behulp van een spreidingsindex. Deze index geeft een indicatie van het aantal beroepsgroepen waarnaar men kan uitwijken.

\section{Vacature}

Het begrip vacature is in deze rapportage gebaseerd op de door het CBS gehanteerde definitie van een openstaande vacature, zijnde een arbeidsplaats waarvoor personeel wordt gezocht dat onmiddellijk of zo spoedig mogelijk geplaatst kan worden.

\section{Vacaturegraad}

De vacaturegraad is het aantal openstaande vacatures per 1.000 werkenden in een bedrijfs-, beroeps- of opleidingssector. 


\section{Vervangingsvraag}

Vervangingsvraag is de vraag naar nieuwe arbeidskrachten die ontstaat doordat de arbeidsplaatsen van werkenden die met pensioen gaan, arbeidsongeschikt worden of zich (tijdelijk) terugtrekken van de arbeidsmarkt, opnieuw moeten worden opgevuld. De vervangingsvraag per beroepsgroep kan bovendien ontstaan door de beroepsmobiliteit. Verder kan een onderscheid worden gemaakt tussen de netto en de bruto vervangingsvraag. De netto vervangingsvraag heeft alleen betrekking op de vervangingsbehoefte voor zover deze opgevuld zou moeten worden door schoolverlaters die op de arbeidsmarkt instromen. De bruto vervangingsvraag is de totale uitstroom van werkenden die vervangen moeten worden. De bruto vervangingsvraag omvat dus ook de vervangingsvraag die zou kunnen worden opgevuld door herintreders en baanwisselaars. In het huidige rapport wordt alleen de netto vervangingsvraag gebruikt en gepresenteerd.

\section{Vraagoverschot}

Het begrip vraagoverschot wordt in dit rapport op twee manieren gebruikt. In enge zin (in hoofdstuk 1) betreft het vraagoverschot het verschil tussen het aantal baanopeningen en het verwachte aanbod van schoolverlaters. In ruime zin (omdat immers ook bij- en omscholing van niet-werkende werkzoekenden een instrument kan zijn om op knelpunten te anticiperen) is het vraagoverschot (in hoofdstuk 4) gedefinieerd als het verschil tussen de som van de openstaande vacatures en de verwachte baanopeningen enerzijds en de direct-inzetbare werkzoekenden - de schoolverlaters en de niet-werkende werkzoekenden in fase 1 - anderzijds.

\section{Werkloosheid onder schoolverlaters}

De werkloosheid onder schoolverlaters is het aantal werklozen uitgedrukt als percentage van het aantal schoolverlaters met een bepaalde opleidingsachtergrond.

\section{Werkloosheid}

Werkloosheid wordt gedefinieerd op basis van de CBS-definitie van de werkloze beroepsbevolking. Tot de werkloze beroepsbevolking worden gerekend de personen die niet of minder dan 12 uur werken en die:

- werk hebben aanvaard waardoor ze ten minste 12 uur per week gaan werken, of;

- verklaren ten minste 12 uur per week te willen werken, daarvoor beschikbaar zijn en activiteiten ontplooien om werk voor ten minste 12 uur per week te vinden.

Het werkloosheidspercentage wordt bepaald door het aantal werklozen te relateren aan de beroepsbevolking.

\section{Werkzoekende}

Het begrip werkzoekende is in deze rapportage gedefinieerd als de bij het Centrum van Werk in Inkomen (CWI) ingeschreven niet-werkende werkzoekenden, inclusief de categorie "geen beroep op dienstverlening". 